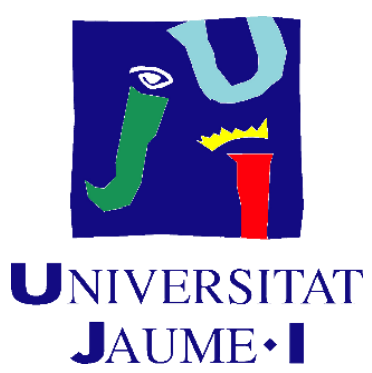

Programa de Doctorado en Ciencias

Escuela de Doctorado de la Universitat Jaume I

\title{
ANÁLISIS DE COMPUESTOS ENDÓGENOS Y EXÓGENOS EN PRODUCTOS DE ACUICULTURA MEDIANTE TÉCNICAS ANALÍTICAS AVANZADAS
}

Memoria presentada por Borja Garlito Molina para optar al grado de doctor por la Universitat Jaume I

Borja Garlito Molina Roque Serrano Gallego Tania Portolés Nicolau 



\section{Financiación recibida}

Agencias financiadoras del doctorando

- $\quad$ Universitat Jaume I (I-4663)

- SCORE-COST Action ES1307. Short Term Scientific Mission (STSM) grant (COST-STSM-ES1307-38094)

Agencias financiadoras del proyecto de investigación o de los recursos materiales específicos del grupo de investigación.

- $\quad$ EU Seventh Framework Programme

- $\quad$ Norwegian Research Council

- $\quad$ Generalitat Valenciana

- $\quad$ Ministerio de economia i competitividad 



\section{Tesis por compendio de las siguientes publicaciones:}

I) T. Portolés, M. Ibáñez, B. Garlito, J. Nácher-Mestre, V. Karalazos, J. Silva, Alm, R. Serrano, J. Pérez-Sánchez, F. Hernández, M.H.G. Berntssen. Comprehensive strategy for pesticide residue analysis through the production cycle of gilthead sea bream and Atlantic salmon. Chemosphere 179 (2017) 242-253. http://dx.doi.org/10.1016/j.chemosphere.2017.03.099. Factor de impacto: 4.427

II) T. Portolés, B. Garlito, Jaime Nácher-Mestre, M.H.G. Berntssen, J. PérezSánchez. Multi-class determination of undesirables in aquaculture samples by gas chromatography/tandem mass spectrometry with atmospheric pressure chemical ionization: A novel approach for polycyclic aromatic hydrocarbons. Talanta 172 (2017) 109-119. http://dx.doi.org/10.1016/j.talanta.2017.05.025. Factor de impacto: 4.244

III) B. Garlito, M. Ibáñez, T. Portolés, R. Serrano, H. Amlund, A-K. Lundebye, M. Sanden, M.H.G. Berntssen, F. Hernández. LC-MS/MS method for the determination of organophosphorus pesticides and their metabolites in salmon and zebrafish fed with plant-based feed ingredients. Analytical and Bioanalytical Chemistry (2019). Factor de impacto: 3.286

IV) B. Garlito, T. Portolés, W.M.A. Niessen, J.C. Navarro, F. Hontoria, Ó. Monroig, I. Varó, R. Serrano. Identification of very long-chain (>C24) fatty acid methyl esters using gas chromatography coupled to quadrupole/time-offlight mass spectrometry with atmospheric pressure chemical ionization source. Analytica Chimica Acta 1051 (2019) 103-109. https://doi.org/10.1016/j.aca.2018.11.001. Factor de impacto: 5.256 
"Esta tesis dispone de la aceptación de los coautores de las publicaciones que el doctorando presenta como tesis y su renuncia expresa a presentarlas como parte de otra tesis doctoral" 


\section{AGRAÏMENTS}

Després de quatre anys, ha arribat el moment de posar punt i final a una etapa. Quatre anys des que iniciàrem, inexperts, un camí ple d'alts i baixos, el de l'assaig-error i la perseverança. A l'escriure aquestes línies, m'ha sobtat la facilitat que tenim per a sintetitzar el treball d'un grapat d'anys - segurament per l'experiència, coneixement i habilitats adquirides - però la dificultat que suposa condensar en pocs paràgrafs la gratitud cap a totes aquelles persones que han fet el camí més planer. A totes i cadascuna de vosaltres, vaja per davant, moltíssimes gràcies!

Aquesta Tesi Doctoral ha estat realitzada en l'Institut Universitari de Plaguicides i Aigües de la Universitat Jaume I, sota la direcció de la Dra. Tania Portolés Nicolau i el Dr. Roque Serrano Gallego. Als meus directors, a la Dra. Elena Pitarch i al Dr. Félix Hernández, m’agradaria agrair-los, en primer lloc, l'oportunitat de formar part del IUPA i d'introduir-me en el món de la investigació. A Roque, també, pel seu optimisme, serenor i consell quan se'ns complicaven els articles. I a Tania, a qui estaré eternament agraït, referent $\mathrm{i}$ punt de suport des del primer dia, per tot el que m'ha ensenyat, ajudat i per la seua paciència infinita.

També voldria agrair al Dr. Joaquín Beltrán, qui fa sis anys va supervisar el meu treball de final de grau, per posar-me, per primera vegada, en contacte amb un espectròmetre de masses. Allà va començar tot. I al Dr. Juan V. Sancho, a qui sempre és un goig escoltar, per l'ajuda rebuda quan els instruments semblaven estar en contra de la font APCI.

I would like to thank Dr. Hans Mol and Marc Tienstra for allowing me to do my research stay at RIKILT-Wageningen University and Research and for our 
stimulating discussions in front of the QOrbitrap. I would also like to thank Dr. Marc H.G. Berntssen for his advice in the field of toxicology that, undoubtedly, has been fundamental in this work.

Amb molta estima, voldria agrair a la resta de professors i a tots els companys i companyes, que estan o han estat al IUPA, la seua ajuda desinteressada durant estos últims quatre anys. Feu fàcil allò que pot semblar difícil. Moltes gràcies a Edu, Rubén i Clara per les partidetes de pàdel i les cervesetes de després; a David pels debats enriquidors; a Nácher per ensenyar-me que l'anàlisi de productes d'aqüicultura és cosa d'acostumar la pituïtària; a Carlos per compartir la desesperació de l'APCI; a María pel comboi d'eixos dinars tan necessaris a Vilavella; a Mercedes pel seu carisma i la seua energia infinita; a Jose, perquè si no parlàrem del Castelló al passadís potser viuríem uns anys menys; i a Montse, Alberto, Leticia, Jorge, Eddie, Robert...pels cafés, cerveses i tertúlies que hem compartit.

Tampoc m'oblide dels amics i amigues amb qui he crescut $i$ viscut, que sempre han estat al meu costat recolzant-me cegament tot i no entendre ben bé allò que feia. Especialmente no me olvido de ti, Alejandro. Tu ausencia es irremplazable. Com no, a tota la gent que conforma la Conlloga, per ensenyarme que el treball cooperatiu i la companyonia inherent a les muixerangues ens pot fer anar més lluny en qualsevol àmbit de la nostra vida. Milions de gràcies!

Y, por último, a mi familia. A mis padres, a Marcos y a mis abuelos por ser mis principales referentes, por estar al pié del cañón, confiando y facilitando mucho las cosas, siempre tendiéndome la mano. I a tu, companya i amiga Isabel, per recolzar-me, escoltar-me, aconsellar-me i acompanyar-me en els camins que se'ns presenten. Gracias a todos vosotros! 


\section{RESUMEN}

Ante el estancamiento de la producción de la pesca de captura desde finales de la década de 1980, y la creciente demanda de pescado y productos pesqueros, la industria acuícola se enfrenta a un importante reto de sostenibilidad dada su dependencia económica y ecológica con respecto a harinas y aceites de origen marino. Por ello, en la última década se han introducido ingredientes vegetales en la composición de los piensos, planteando un nuevo escenario en el ámbito de la seguridad alimentaria y la salud animal.

En la presente Tesis Doctoral se ha estudiado el potencial analítico y la aplicabilidad de diferentes acoplamientos cromatografía-espectrometría de masas en el campo del análisis de contaminantes orgánicos y compuestos endógenos en muestras de acuicultura. La variedad y el potencial de los acoplamientos instrumentales han permitido optimizar el alcance de los análisis y desarrollar metodología analítica sensible, selectiva y fiable, desde un enfoque cualitativo y cuantitativo.

El trabajo presentado se ha estructurado en dos bloques: un primer bloque donde se aborda el análisis de contaminantes orgánicos, y un segundo dedicado al estudio de compuestos endógenos.

El primer bloque está formado por tres trabajos consecutivos y relacionados entre ellos que abordan, desde diferentes perspectivas, las problemáticas en el ámbito de la seguridad alimentaria y la salud animal surgidas en campo de la acuicultura. En este bloque se desarrollan métodos analíticos para la determinación de pesticidas, hidrocarburos policíclicos aromáticos (PAHs) y bifenilos policlorados (PCBs) en ingredientes, piensos y pescado de 
acuicultura. En el primero de los trabajos presentados se estudia el potencial de la cromatografía de líquidos acoplada a espectrometría de masas híbrida cuadrupolo-tiempo de vuelo (LC-QTOF MS) y la cromatografía de gases acoplada a QTOF MS con fuente de ionización APCI (GC-APCI-QTOF MS) para el desarrollo de una estrategia de screening integral de pesticidas. A una primera etapa de validación cualitativa para 253 pesticidas a 10 y $50 \mathrm{ng} \cdot \mathrm{g}^{-1}$, le sigue la aplicación del método para el análisis de muestras mediante las aproximaciones target y suspect screening.

En el segundo trabajo, surgido a partir de los resultados obtenidos en el trabajo anterior, se desarrolla un método basado en la cromatografía de gases acoplada a espectrometría de masas en tándem con fuente de ionización APCI (GCAPCI-MS/MS) para la determinación de PAHs, PCBs y los pesticidas detectados en el screening anterior. El objetivo principal de este trabajo es estudiar el potencial de la fuente APCI junto con el analizador de triple cuadrupolo (QqQ) con el fin de explorar la posibilidad de reducir el efecto matriz mediante dilución simple del extracto y, en consecuencia, cuantificar usando curvas de calibración en solvente relativas a un patrón interno. El método final se valida satisfactoriamente a 2, 5 y $50 \mathrm{ng} \cdot \mathrm{g}^{-1}$ en diferentes matrices para la mayoría de compuestos mediante la cuantificación por calibrado en solvente.

Para finalizar, en el tercer trabajo de este bloque se desarrolla un método analítico basado en la cromatografía de líquidos acoplada a espectrometría de masas en tándem (LC-MS/MS) para la determinación de pirimiphos-methyl, chlopyrifos-methyl y sus principales metabolitos en pez cebra y salmón sometidos a la exposición dietaria de estos pesticidas. Este trabajo surge de los resultados obtenidos en los dos trabajos anteriores y pretende dar respuesta, 
desde una aplicación analítica en el ámbito de la toxicología, a la ausencia de límites máximos de residuo (MRLs) de los analitos mencionados en pescado. Los resultados obtenidos permitirán generar un modelo cinético de acumulación y eliminación de pirimiphos-methyl en el salmón que contribuirá a establecer MRLs seguros y objetivos en pescado.

El segundo bloque aborda el estudio de ácidos grasos poliinsaturados de cadena muy larga (VLC-PUFA) en muestras de retina de pescado. En el cuarto trabajo presentado en la Tesis Doctoral se estudia el potencial de la fuente APCI en el acoplamiento GC-APCI-QTOF MS, como alternativa a la ionización electrónica, para la identificación de las series $\omega 3$ y $\omega 6$ de estos compuestos. Para este fin, se genera un modelo estadístico basado en el análisis ortogonal de mínimos cuadrados parciales discriminantes (OPLS-DA) que destaca la abundancia relativa entre dos iones como la variable diferenciadora de ambos grupos. La aplicación del modelo al análisis de muestras reales, junto con la presencia de la molécula protonada en el espectro de masas, permite diferenciar e identificar satisfactoriamente los isómeros de las series $\omega 3$ y $\omega 6$. 



\section{SUMMARY}

Due to the stagnation of capture fisheries since the late 1980s, and the growing demand for fish and fishery products, the aquaculture industry faces a major sustainability challenge given its economic and ecological dependence on fishmeals and fish oils. Therefore, in the last decade plant ingredients have been introduced in the composition of feed, posing a new scenario in the field of food safety and animal health.

In this Doctoral Thesis the analytical potential and applicability of different chromatography-mass spectrometry couplings in the field of organic pollutants and endogenous compounds analysis in aquaculture samples have been studied. The variety and potential of the instrumental couplings has allowed optimizing the scope of the analysis and developing sensitive, selective and reliable analytical methodology, in both qualitative and quantitative approaches.

The work presented has been structured in two blocks: a first block focused on the analysis of organic pollutants, and a second one dedicated to the study of endogenous compounds.

The first block is formed by three consecutive and related works that address, from different perspectives, the problems in the field of food safety and animal health arising in the field of aquaculture. In this block, analytical methods for the determination of pesticides, polycyclic aromatic hydrocarbons (PAHs) and polychlorinated biphenyls (PCBs) in aquaculture ingredients, feed and fish are developed. In the first work, the potential of liquid chromatography coupled to hybrid quadrupole-time of flight mass spectrometry (LC-QTOF MS) and gas chromatography coupled to QTOF MS with APCI ionization source (GC- 
APCI-QTOF MS) are studied for the development of a comprehensive pesticide screening strategy. In a first step, the method is qualitatively validated for 253 pesticides at 10 and $50 \mathrm{ng} \cdot \mathrm{g}^{-1}$, and then it is applied to the analysis of samples using target and suspect screening approaches.

In the second work, a method based on gas chromatography coupled to tandem mass spectrometry with APCI ionization source (GC-APCI-MS/MS) is developed for the determination of PAHs, PCBs and the pesticides detected in the previous screening. The main objective of this work is to study the potential of the APCI source coupled to triple quadrupole mass analyzer (QqQ) in order to explore the possibility of reducing the matrix effect by simple dilution of the final extract and, consequently, quantify using calibration curves with standards in solvent. The final method is successfully validated at 2, 5 and $50 \mathrm{ng} \cdot \mathrm{g}^{-1}$ in different matrices for most compounds using calibration with standards in solvent for quantification.

Finally, in the third work of this block, an analytical method based on liquid chromatography coupled to tandem mass spectrometry (LC-MS/MS) is developed for the determination of pirimiphos-methyl, chlorpyrifos-methyl and their main metabolites in dietary exposure experiments in zebrafish and salmon. This work arises from the results obtained in the two previous works and aims to respond, from an analytical application in the field of toxicology, to the absence of maximum residue limits (MRLs) for the mentioned pesticides in fish. The results obtained will be essential for developing a kinetic model of accumulation and elimination of pirimiphos-methyl in salmon, and will contribute to establish relevant MRLs for fish.

The second block addresses the study of very long chain polyunsaturated fatty 
acids (VLC-PUFA) in fish retina. In the fourth paper presented in the Doctoral Thesis, the potential of the GC-APCI-QTOF MS coupling is studied, as an alternative to electron ionization, for the reliable identification of the $\omega 3$ and $\omega 6$ series of these compounds. To this aim, a statistical model is generated based on the orthogonal partial least squares discriminant analysis (OPLSDA) that highlights the relative abundance between two ions as the differentiating variable of both groups. The application of the model to the analysis of real samples, together with the presence of the protonated molecule in the mass spectrum, make it possible to differentiate and identify the isomers of the $\omega 3$ and $\omega 6$ series. 



\section{ÍNDICE GENERAL}

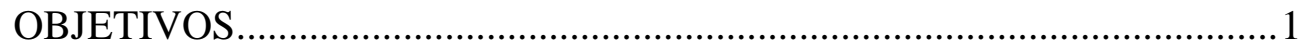

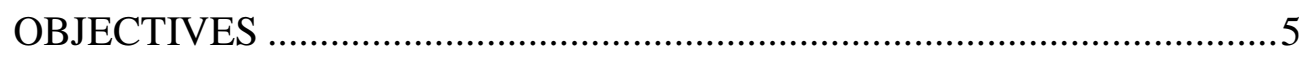

CAPÍTULO 1. INTRODUCCIÓN GENERAL........................................... 9

1.1. Retos actuales de la acuicultura ......................................................... 13

1.2. Seguridad alimentaria y salud animal............................................... 16

1.3. Técnicas analíticas para el control alimentario................................... 18

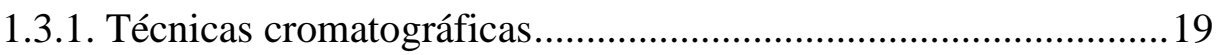

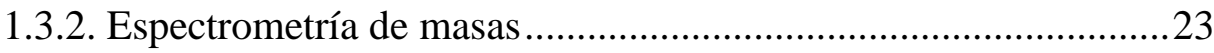

1.4. Estrategias analíticas para el control alimentario ................................33

1.5. Tratamiento de muestra en matrices de acuicultura. ...........................36

1.6. Estrategias de corrección del efecto matriz.........................................38

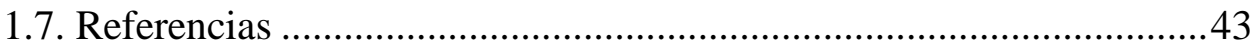

CAPÍTULO 2. DETERMINACIÓN DE COMPUESTOS EXÓGENOS MEDIANTE EL USO DE ESPECTROMETRÍA DE MASAS CON ANALIZADOR DE CUADRUPOLO-TIEMPO DE VUELO Y TRIPLE

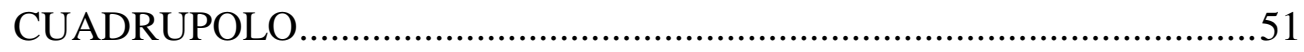

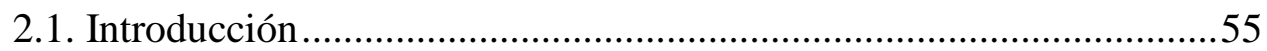

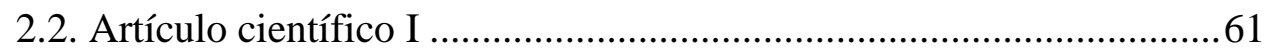


Comprehensive strategy for pesticide residue analysis through the production cycle of gilthead sea bream and Atlantic salmon

Chemosphere, 179, 242-253, 2017

2.3. Artículo científico II 105

Multi-class determination of undesirables in aquaculture samples by gas chromatography/tandem mass spectrometry with atmospheric pressure chemical ionization: A novel approach for polycyclic aromatic hydrocarbons

Talanta, 172, 109-119, 2017

2.4. Discusión de los resultados obtenidos 153

2.5. Referencias 163

CAPÍTULO 3. ESTUDIO DE LA TRANSFERENCIA DE CONTAMINANTES ORGÁNICOS A TRAVÉS DE LA DIETA EN SALMÓN ATLÁNTICO MEDIANTE CROMATOGRAFÍA DE LÍQUIDOS ACOPLADA A ESPECTROMETRÍA DE MASAS EN TÁNDEM ......... 167

3.1. Introducción 171

3.2. Artículo científico III 173

LC-MS/MS method for the determination of organophosphorus pesticides and their metabolites in salmon and zebrafish fed with plant-based feed ingredients

Analytical and Bioanalytical Chemistry, 2017

3.3. Discusión de los resultados obtenidos. 203 
CAPÍTULO 4. DETERMINACIÓN DE COMPUESTOS ENDÓGENOS MEDIANTE EL USO DE ESPECTROMETRÍA DE MASAS CON ANALIZADOR DE CUADRUPOLO-TIEMPO DE VUELO Y FUENTE DE IONIZACIÓN APCI .............................................................................209

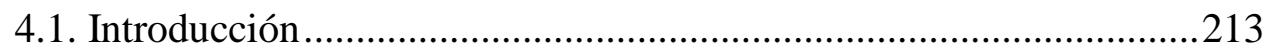

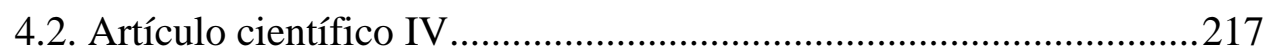

Identification of very long-chain (>C24) fatty acid methyl esters using gas chromatography coupled to quadrupole/time-of-flight mass spectrometry with atmospheric pressure chemical ionization source

Analytica Chimica Acta, 1051, 103-109, 2019

4.3. Discusión de los resultados obtenidos.

4.4. Referencias 251

CAPÍTULO 5. CONCLUSIONES/CONCLUSIONS .... .255

SUGERENCIAS PARA FUTUROS TRABAJOS .261

SUGGESTIONS FOR FUTURE WORKS .263

ARTÍCULOS RELACIONADOS/RELATED ARTICLES .265 



\section{ÍNDICE DE ACRÓNIMOS}

2-DAMP

AOAC

APCI

API

ARA

CEN

CI

CID

DC

DHA

d-SPE

EFSA

EI

ELOVL4

EPA

ESI

FAME

GAP

GC

GCB

GC-APCI-

MS/MS 2-(diethylamino)-6-methyl-4-pyrimidinol

Asociación de Comunidades Analíticas

Ionización química a presión atmosférica

Ionización a presión atmosférica

Ácido araquidónico

Comité Europeo de Normalización

Ionización química

Disociación inducida por colisión

Corriente continua

Ácido docosohexaenoico

Extracción en fase sólida dispersiva

Autoridad Europea de Seguridad Alimentaria

Ionización electrónica

Elongasa de ácidos grasos de cadena muy larga 4

Ácido eicosapentaenoico

Interfase electrospray

Éster metílico de ácido graso

Buenas prácticas agrícolas

Cromatografía de gases

Carbón negro grafitizado

Cromatografía de gases acoplada a espectrometría de masas en tándem con fuente de ionización química a presión atmosférica 
GC-APCI- Cromatografía de gases acoplada a espectrometría de QTOF MS masas híbrida cuadrupolo-tiempo de vuelo con fuente de ionización química a presión atmosférica

GC-MS Cromatografía de gases acoplada a espectrometría de masas

GC-MS/MS Cromatografía de gases acoplada a espectrometría de masas en tándem

GPC Cromatografía por permeación en gel

HE Función de alta energía

HPLC Cromatografía de líquidos de alta resolución

HRMS Espectrometría de masas de alta resolución

IP Punto de identificación

IS Patrón interno

LC Cromatografía de líquidos

LC-MS Cromatografía de líquidos acoplada a espectrometría de masas

LC-MS/MS Cromatografía de líquidos acoplada a espectrometría de masas en tándem

LC-QTOF MS Cromatografía de líquidos acoplada a espectrometría de masas híbrida cuadrupolo-tiempo de vuelo

LC-PUFA Ácido graso poliinsaturado de cadena larga

LC-PUFA-ME Éster metílico de ácido graso poliinsaturado de cadena larga

LE Función de baja energía

$m / z \quad$ Relación masa/carga

$\mathbf{M}^{+\cdot} \quad$ Ion molecular

$[\mathbf{M}+\mathbf{H}]^{+} \quad$ Molécula protonada 
MAE

MRL

MS

MS/MS

NCI

N-Des-PM

OPLS-DA

PAHs

PBDEs

PC

PCA

PCBs

PLE

POPs

PRM

PSA

PTV

Q

$\mathbf{q} / \mathbf{Q}$

QqQ

QTOF

QuEChERS

RF

$\mathbf{S} / \mathbf{N}$
Extracción asistida por microondas

Límites máximos de residuo

Espectrometría de masas

Espectrometría de masas en tándem

Ionización química negativa

O-[2-(ethylamino)-6-methylpyrimidin-4-yl]O,O-

dimethylphosphorothioate

Análisis ortogonal de mínimos cuadrados parciales

discriminante

Hidrocarburos policíclicos aromáticos

Difeniléteres polibromados

Fosfatidilcolina

Análisis de componentes principales

Bifenilos policlorados

Extracción líquida presurizada

Contaminantes orgánicos persistentes

Monitorización de la reacción paralela

Amina primaria-secundaria

Vaporización con temperatura programada

Filtro de masas cuadrupolar

Ratio iónica

Analizador de masas de triple cuadrupolo

Analizador de masas híbrido cuadrupolo-tiempo de vuelo

Rápido, fácil, barato, efectivo, robusto, seguro

Radiofrecuencia

Relación señal/ruido 
SDL

SFE

SIL-IS

SIM

SOFIA

SPE

SRM

TCP

TOF

UE

UHPLC

USE

VLC-PUFA

VLC-PUFA-ME Éster metílico de ácidos graso poliinsaturado de cadena muy larga

Límite de detección de screening

Extracción con fluidos supercríticos

Patrón interno marcado con isótopos estables

Monitorización del ion seleccionado

Estado Mundial de la Pesca y la Acuicultura

Extracción en fase sólida

Monitorización de la transición seleccionada

3,5,6-trichloropyridinol

Analizador de masas de tiempo de vuelo

Unión Europea

Cromatografía de líquidos de ultra alta resolución

Extracción mediante ultrasonidos

Ácido graso poliinsaturado de cadena muy larga 
OBJETIVOS 



\section{OBJETIVOS}

El objetivo principal de la presente Tesis Doctoral es explorar el potencial analítico de la cromatografía de gases (GC) y de líquidos de ultra alta resolución (UHPLC) acopladas a espectrometría de masas (MS), tanto en modo simple como tándem (MS/MS), usando analizadores de triple cuadrupolo (QqQ) e híbrido cuadrupolo-tiempo de vuelo (QTOF), para la determinación de compuestos exógenos y endógenos en el campo de la acuicultura. Con ello, se pretende avanzar en el conocimiento de los nuevos retos que este campo está abordando en aras de la rentabilidad y sostenibilidad.

En primer lugar, se diseña una estrategia integral, mediante el uso de GCQTOF MS con fuente de ionización química a presión atmosférica (APCI), UHPLC-QTOF MS con fuente electrospray (ESI) y GC-(APCI)-MS/MS con QqQ para el análisis de contaminantes orgánicos en muestras procedentes de la acuicultura. En segundo lugar, se desarrolla un método UHPLC-MS/MS con QqQ para llevar a cabo un estudio de migración de contaminantes de piensos a tejidos de pescado. Por último, se aplica el potencial de la técnica GC-(APCI)-QTOF MS para la elucidación y caracterización de ácidos grasos de cadena muy larga (VLC-PUFA) cuyos estándares y espectros de ionización electrónica no están disponibles.

Con el fin de alcanzar el objetivo principal, se establecen los siguientes objetivos específicos:

1. Desarrollar, validar y aplicar un método analítico basado en GC-(APCI)QTOF MS y UHPLC-QTOF MS para el screening de contaminantes orgánicos, tanto en modo target como suspect, en diversos tipos de muestras de acuicultura. 
2. Desarrollar, validar y aplicar un método analítico basado en GC-(APCI)MS/MS con QqQ para la cuantificación y confirmación de los contaminantes orgánicos detectados en el screening de las muestras analizadas anteriormente.

3. Explorar el potencial de la fuente APCI en combinación con GC-MS/MS con $\mathrm{QqQ}$, como técnica para la determinación de contaminantes orgánicos en un amplio número de matrices complejas. Estudiar el efecto matriz y el potencial del método con el fin de utilizar calibrado en solvente. Este objetivo específico pone especial énfasis en los hidrocarburos policíclicos aromáticos.

4. Desarrollar y validar un método analítico basado en UHPLC-MS/MS con QqQ para la cuantificación y confirmación de pirimiphos-methyl, chlorpyriphos-methyl y sus principales metabolitos en piensos y tejidos de pez cebra y salmón; y generar datos para un futuro estudio de migración de contaminantes de piensos a tejidos de pescado.

5. Estudiar el potencial del acoplamiento GC-(APCI)-QTOF MS para la elucidación y caracterización de VLC-PUFA, cuyos espectros de ionización electrónica no se encuentran en librerías comerciales y cuyos estándares analíticos no están disponibles comercialmente. Utilización de herramientas estadísticas para el estudio de espectros de masas de compuestos isoméricos. 


\section{OBJECTIVES}





\section{OBJECTIVES}

The main objective of this Doctoral Thesis is to explore the analytical capabilities of GC and UHPLC coupled to MS using triple quadrupole (QqQ) and hybrid quadrupole-time of flight (QTOF) for the determination of exogenous and endogenous compounds in the aquaculture field. With this, we intend to advance in the knowledge of the new challenges that this field is addressing in the interests of profitability and sustainability.

First, a comprehensive strategy is generated using GC-(APCI)-QTOF MS, UHPLC-QTOF MS and GC-(APCI)-MS/MS with QqQ for the analysis of organic contaminants in aquaculture samples. Secondly, a UHPLC-MS/MS with QqQ method is developed to carry out a migration study of feed contaminants to fish tissues. Finally, the potential of the GC-(APCI)-QTOF MS technique is explored for the elucidation and characterization of compounds whose standards and electron ionization spectra are not available.

Specific objectives of the Thesis are the following:

1. Development, validation and application of an analytical method based on GC-(APCI)-QTOF MS and UHPLC-QTOF MS for the screening of organic pollutants, both in target and suspect mode, in aquaculture samples.

2. Development, validation and application of an analytical method based on GC-(APCI)-MS/MS with QqQ for the quantification and confirmation of organic contaminants previously detected in the screening analysis.

3. Study the potential of APCI, in combination with GC-MS/MS with QqQ, as a technique for the determination of organic pollutants in complex matrices 
using calibration in solvent. Emphasis on polycyclic aromatic hydrocarbons.

4. Development and validation of an analytical method based on UHPLCMS/MS with QqQ for the quantification and confirmation of pirimiphosmethyl, chlorpyrifos-methyl and their main metabolites in feed and tissues of zebrafish and salmon, to generate analytical data for a future feed-to-fillet transfer study.

5. Investigation of the capabilities of GC-(APCI)-QTOF MS coupling for the elucidation and characterization of compounds whose EI spectra and analytical standards are not available. Use of statistical tools for the study of mass spectra of isomeric compounds. 


\section{CAPÍTULO 1}

\section{INTRODUCCIÓN GENERAL}





\section{CAPÍTULO 1: INTRODUCCIÓN GENERAL}

1.1. Retos actuales de la acuicultura

1.2. Seguridad alimentaria y salud animal

1.3. Técnicas analíticas para el control alimentario

1.3.1. Técnicas cromatográficas

1.3.2. Espectrometría de masas

1.3.2.1. Fuentes de ionización

1.3.2.2. Analizadores de masas

1.4. Estrategias analíticas para el control alimentario

1.5. Tratamiento de muestra en matrices de acuicultura.

1.6. Estrategias de corrección del efecto matriz

1.7. Referencias 



\subsection{Retos actuales de la acuicultura}

Ante la previsión de crecimiento de la población mundial por encima de los 9.700 millones de personas en el año 2050 [1], la comunidad mundial se enfrenta al gran reto de asegurar un suministro alimentario y nutricional adecuado a una población cada vez más numerosa, garantizando un desarrollo sostenible en términos económicos, sociales y ambientales.

Según el último informe del "Estado Mundial de la Pesca y la Acuicultura" (SOFIA) [2], el pescado - que representa aproximadamente el 17\% del consumo de proteínas de origen animal a escala mundial - registró un aumento en su consumo per cápita de 9,9 kg en la década de 1960 hasta superar los 20 $\mathrm{kg}$ en la actualidad. Asimismo, el comercio mundial de pescado y productos pesqueros destinados al consumo humano se ha quintuplicado en los últimos cuarenta años pese a que el estado de los recursos marinos mundiales no ha mejorado. Actualmente, casi un tercio de las poblaciones de peces con valor comercial se capturan a un nivel biológicamente insostenible. Por ello, la producción de pescado y productos pesqueros ha dejado de basarse mayoritariamente en la captura de peces salvajes [2].

Ante el estancamiento de la producción de la pesca de captura desde finales de la década de 1980, y la creciente demanda de pescado y productos pesqueros, la acuicultura ha sido la desencadenante del importante crecimiento del suministro mundial (figura 1). Si bien la acuicultura proporcionaba en torno al 6\% del pescado consumido en 1970, este porcentaje aumentó hasta el 30\% en el año 2000, hasta superar el 50\% en la actualidad; y las previsiones indican que la producción acuícola crecerá un 39\% respecto al periodo comprendido entre el 2013 y 2015 [2]. 


\section{PRODUCCIÓN MUNDIAL DE LA PESCA DE CAPTURA Y ACUICULTURA}

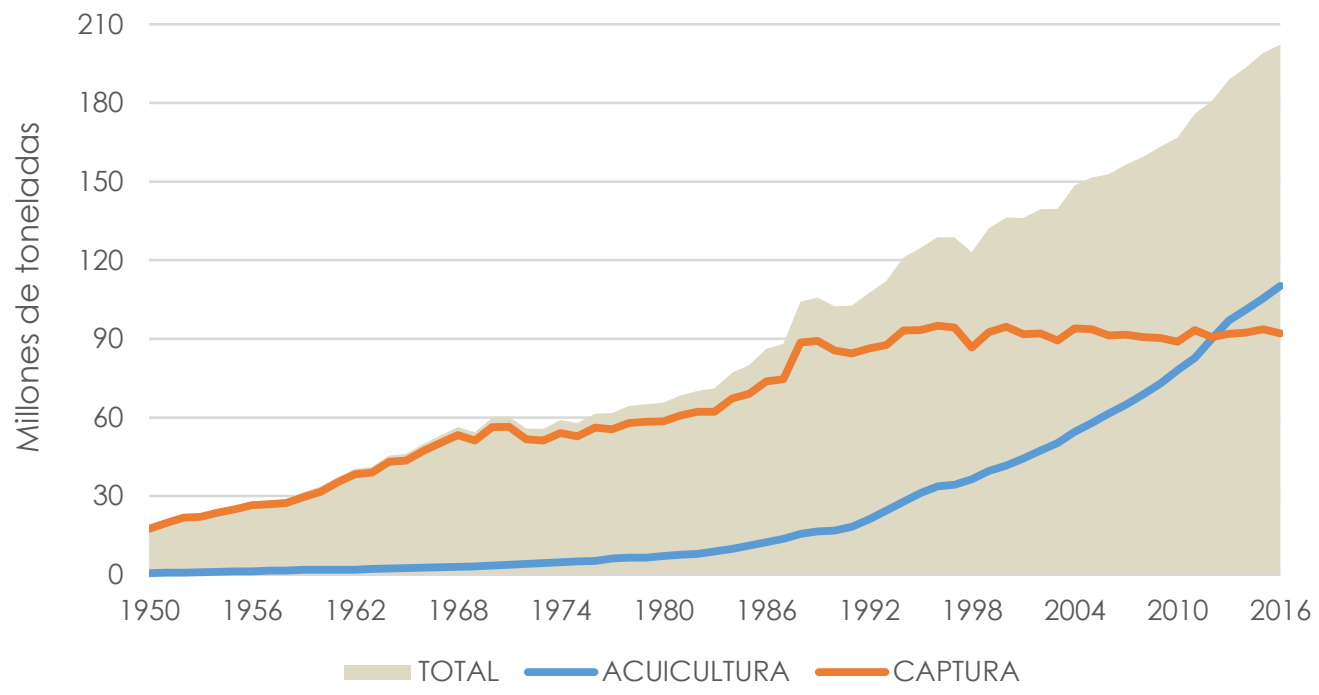

Figura 1: Producción mundial de pesca de captura y acuicultura. Datos extraídos de la web http://www.fao.org/fishery/topic/16140/es (visitada el 20/05/2019).

Así pues, en el contexto actual de rápido crecimiento y aumento de la demanda de productos de pesca, la industria acuícola se enfrenta a un importante reto de sostenibilidad dada su dependencia económica y ecológica con respecto a harinas y aceites de origen marino. Estas materias primas proceden de la pesca extractiva y se utilizan para la producción de piensos. Sin embargo, el suministro de estas se encuentra en su límite sostenible, lo que comporta que la expansión de esta industria deba realizarse usando fuentes alternativas de ingredientes. Por ello, en la última década se han introducido ingredientes vegetales en la composición de los piensos. A modo de ejemplo, en el caso del salmón atlántico, los piensos han pasado de estar formados en su totalidad por ingredientes de origen marino a contener un $70 \%$ de ingredientes vegetales, principalmente aceites [3]. 
Estos cambios en la composición de las dietas plantean varias problemáticas. En primer lugar, la acuicultura moderna depende de la adecuada provisión de ácidos grasos poliinsaturados de cadena larga (LC-PUFA) de la serie omega3 , esenciales para satisfacer los requerimientos fisiológicos [4]. No obstante, el uso de ingredientes vegetales, ricos en LC-PUFA omega-6, compromete la correcta provisión de LC-PUFA omega-3. Por un lado, la importancia de los LC-PUFA omega-3 ha sido puesta de manifiesto en numerosos estudios que resaltan el papel fundamental en diversos procesos fisiológicos y metabólicos que aseguran el correcto funcionamiento celular [5]. Por otra parte, el pescado representa la principal fuente de LC-PUFA omega-3 para el consumo humano. Así pues, el cambio en la composición de las dietas de los peces podría tener efectos negativos tanto en la composición nutricional del producto como en la salud de los individuos cultivados.

En segundo lugar, se ha demostrado que el uso de ingredientes vegetales, junto con técnicas comerciales de descontaminación [6-8], se ha traducido en la disminución de contaminantes orgánicos persistentes (POPs) en peces de cultivo $[9,10]$. Sin embargo, con la sustitución de los ingredientes tradicionales se han incrementado los niveles de otros contaminantes como hidrocarburos policíclicos aromáticos (PAHs), relacionados con el tratamiento térmico de los ingredientes vegetales, y se han introducido nuevos contaminantes no asociados a las actividades de cría, como plaguicidas [1113]. Para garantizar la seguridad alimentaria, la mayoría de alimentos tienen establecidos límites máximos de residuo (MRLs) por la Unión Europea (UE). Sin embargo, en el caso del pescado, piensos e ingredientes de acuicultura todavía no los tienen. Por ello, el conocimiento de los factores de migración y el efecto de estos contaminantes sobre los peces son necesarios para establecer límites máximos apropiados. 
Por consiguiente, el gran reto actual de la acuicultura es la producción de peces alimentados con dietas sostenibles y seguras que posibiliten el normal desarrollo y crecimiento del pez en cautividad y que garanticen la seguridad alimentaria al consumidor.

\subsection{Seguridad alimentaria y salud animal}

El Reglamento (CE) No 178/2002 [14] define los principios de la política de seguridad alimentaria de la UE con la finalidad de establecer una base común para las medidas aplicables a los productos en el ámbito nacional y comunitario, facilitar la libre circulación de productos entre los países de la UE, garantizar un nivel elevado de protección de la salud de las personas y de los animales, y proteger los intereses de los consumidores mediante acciones a lo largo de la cadena de producción alimentaria. Para este fin, la legislación se basa en datos científicos y en una evaluación minuciosa del riesgo proporcionado por agencias independientes, como la Autoridad Europea de Seguridad Alimentaria (EFSA), que tiene el cometido de prestar asesoramiento científico-técnico, emitir dictámenes y actuar ante las crisis de seguridad alimentaria.

Una de las principales competencias de la UE en materia de seguridad alimentaria es garantizar el bienestar animal de las especies cultivadas para la producción de alimentos. Este ámbito, que comprende factores como las condiciones de espacio y temperatura de cría, las condiciones de transporte o los métodos de sacrificio, está estrechamente vinculado con la salud animal y las enfermedades transmitidas por éstos, comprometiendo, por tanto, la seguridad de la cadena alimentaria. Por ello, todos los factores relacionados 
con el bienestar animal fueron abordados en 1976 en la European Convention for the Protection of Animals kept for Farming Purposes [15], donde se establecieron los principios comunes para la protección de animales cultivados.

De entre todos los factores, uno de los que más interés científico despierta y que mayor efecto tiene sobre el bienestar animal y la seguridad alimentaria, es la alimentación de los individuos de cría. Por una parte, según los principios acordados en la European Convention for the Protection of Animals kept for Farming Purposes, los animales deben ser provistos de alimentos que sean adecuados para sus necesidades fisiológicas y etológicas. Con este fin, y en relación con la problemática en la sostenibilidad de los piensos expuesta en el primer punto de la introducción, la acuicultura moderna está centrando sus esfuerzos en ampliar el conocimiento científico. De hecho, la UE ha financiado proyectos como "AQUAMAX", "ARRAINA" o "PUFAFEEDS", entre otros, dirigidos a esta materia. Por otra parte, dichos alimentos deben estar exentos de sustancias que puedan causar daños o lesiones innecesarias. Por ello, la UE ha establecido MRLs para determinadas sustancias tóxicas en ingredientes y piensos para peces - como PAHs, bifenilos policlorados (PCBs) o dioxinas [11] - con el objetivo de controlar y reducir los niveles de estas sustancias así como su seguridad. A pesar de todo, los avances en el campo de la acuicultura, con el desarrollo de nuevos piensos de composición principalmente vegetal, han planteado un escenario escasamente contemplado por la legislación vigente. Pese a la existencia de MRLs de plaguicidas para gran parte de alimentos de carácter vegetal, los cuales han sido establecidos en base a buenas prácticas agrícolas (GAP), los cultivos utilizados en la alimentación animal, piensos y productos de acuicultura no han sido contemplados. Es por ello que urge una evaluación del efecto de los residuos 
de los plaguicidas y de los posibles riesgos para la salud del consumidor y del animal, siendo estos estudios llevados a cabo normalmente por agencias como la EFSA. A partir de estos se establecerían los MRLs correspondientes.

Para controlar el cumplimiento de dichos MRLs es necesario realizar análisis periódicos, utilizando métodos analíticos fiables, robustos y estrictamente validados siguiendo las últimas versiones de guías de calidad analítica como la SANTE/11813/2017 [16]. Es aquí, pues, donde los últimos avances en la investigación analítica se han convertido en un elemento imprescindible en el área de la seguridad alimentaria. El desarrollo de metodología analítica sofisticada, que incorpore los últimos avances en el ámbito instrumental, resulta crucial a la hora de determinar residuos de plaguicidas $\mathrm{u}$ otras sustancias contaminantes con un alto grado de fiabilidad, y capaz de cumplir con las exigencias de la legislación vigente.

\subsection{Técnicas analíticas para el control alimentario}

En las últimas décadas, ha habido una creciente preocupación en el ámbito de la seguridad alimentaria. Ante esta preocupación, el desarrollo de metodologías analíticas para la determinación de contaminantes orgánicos y compuestos endógenos ha supuesto un avance evidente en el campo del control alimentario y ambiental. Sin embargo, su determinación continúa siendo un desafío. El elevado número de compuestos de interés con propiedades físico-químicas muy diferentes, la complejidad de las muestras a analizar y los bajos niveles de concentración a los que habitualmente se encuentran, requieren de instrumentación analítica poderosa. A este respecto, los acoplamientos GC-MS y LC-MS se han consolidado como las técnicas 
más ampliamente utilizadas en este ámbito [17]. Asimismo, la espectrometría de masas presenta mucha versatilidad, debido sobre todo a los diferentes analizadores que existen, así como las fuentes de ionización disponibles.

A lo largo de los trabajos presentados en esta tesis, y con el objetivo de abarcar un amplio abanico de contaminantes orgánicos de diferente naturaleza, se han utilizado tanto la GC como la LC acopladas a espectrometría de masas con diferentes tipos de analizadores. A continuación, se describirán brevemente los fundamentos de las técnicas utilizadas en esta Tesis.

\subsubsection{Técnicas cromatográficas}

La cromatografía se define como un método físico de separación en el que los componentes de una mezcla se distribuyen entre dos fases, una estacionaria y otra móvil que se mueve en una dirección determinada. El proceso cromatográfico ocurre como resultado de la interacción de los componentes con la fase estacionaria y la separación de éstos dependerá de las diferencias en sus coeficientes de distribución [18].

La clasificación de las técnicas cromatográficas se basa en la naturaleza física de la fase móvil, siendo un gas inerte en la cromatografía de gases (GC) y un líquido en la cromatografía de líquidos (LC).

\section{Cromatografía de gases}

La cromatografía de gases es una técnica de separación basada en la presión de vapor relativa de los analitos y la interacción de éstos con una fase estacionaria contenida en el interior de la columna cromatográfica [19]. Se 
trata de una técnica muy útil para la separación de compuestos volátiles o semivolátiles y necesariamente termoestables como, por ejemplo, los PAHs, PCBs o algunos plaguicidas.

El pilar central de la cromatografía de gases reside en la columna cromatográfica. Actualmente, la mayoría de las aplicaciones utilizan columnas capilares debido a su alta eficacia de separación y a la gran variedad de características químicas, dimensiones y espesor de la fase estacionaria disponibles comercialmente. Esto ha permitido optimizar sus propiedades a la naturaleza de los analitos y matrices, mejorando así la sensibilidad de su detección respecto a otras columnas. No obstante, una buena separación cromatográfica está estrechamente ligada a la primera etapa de todo proceso cromatográfico: la inyección de la muestra al sistema.

La inyección de la muestra en GC es una etapa crítica que debe realizarse adecuadamente para asegurar una óptima transferencia de los analitos a la columna. En función de las características de las muestras, la naturaleza de los analitos, la volatilidad del disolvente y el sistema cromatográfico, existen diferentes técnicas de inyección para columnas capilares. Entre las más utilizadas se encuentran:

Inyección con división de muestra o split: permite la introducción en la columna capilar de una fracción de la muestra inyectada a alta temperatura en la cámara de vaporización, mediante el ajuste de los flujos de gas portador y gas de purga. Se usa principalmente para evitar la saturación de la fase estacionaria al inyectar muestras muy concentradas o sucias [20].

Inyección sin división de muestra o splitless: utilizando el mismo sistema instrumental que la inyección en modo split, permite introducir 
prácticamente la totalidad de la muestra inyectada en la columna capilar ya que, a diferencia del anterior, la válvula de purga se encuentra cerrada en el momento de la inyección. Es la técnica ampliamente utilizada en el análisis de trazas pese a requerir un tratamiento de muestra severo [20]. En los artículos científicos I, II y IV se ha empleado la inyección mediante el sistema pulsed splitless. Se trata de un sistema splitless en el cual, cuando la muestra es inyectada, aumenta notablemente el flujo de gas portador, favoreciendo la transferencia de los analitos a la columna. Como resultado, se reducen posibles fenómenos de discriminación, adsorción y/o degradación de los analitos en la cámara de vaporización [21].

* Inyección en columna: permite la inyección de la muestra directamente en la columna capilar, sin necesidad de una cámara de vaporización. Los analitos se separan del disolvente mediante efectos térmico y de solvente. Esta técnica evita problemas de discriminación y posible degradación térmica. No obstante, requiere de mayor tratamiento de muestra para generar extractos limpios y así evitar el deterioro de la cabeza de columna [20].

* Inyección de vaporización con temperatura programada (PTV): se trata de un híbrido de las técnicas descritas anteriormente. La muestra se introduce a baja temperatura en un inyector split/splitless y, posteriormente, la cámara de vaporización se calienta rápidamente para desorber la muestra en la columna capilar. Esta técnica permite la inyección de grandes volúmenes de muestra, aportándole mayor versatilidad [20]. 


\section{Cromatografía de líquidos}

La cromatografía de líquidos es una técnica de separación basada en la diferencia de afinidad de los compuestos de una muestra entre una fase móvil, líquida, compuesta por una mezcla de disolventes con diferente fuerza eluotrópica; y una fase estacionaria, sólida, empaquetada en una columna. Se trata de una técnica muy versátil y especialmente útil para la separación de compuestos con carácter polar, poco volátiles y termolábiles.

Al igual que en GC, la columna cromatográfica es determinante en el proceso de separación. Así, en función del tipo de las partículas de relleno se producirá un tipo u otro. El tipo de separación cromatográfica más ampliamente utilizado en LC es la denominada fase reversa, es decir, la que utiliza una fase estacionaria apolar formada normalmente por sílice modificada con grupos octadecilo $\left(\mathrm{C}_{18}\right)$. Como fase móvil, se utilizan mezclas de agua con disolventes orgánicos, como metanol o acetonitrilo, que pueden contener modificadores para mejorar la retención, forma de pico y/o sensibilidad de ciertos compuestos. En este tipo de cromatografía, en la que la retención disminuye generalmente al aumentar la polaridad del analito, las interacciones entre analito y solvente son las que determinan su especificidad, ya que las interacciones de los analitos con la fase estacionaria son relativamente débiles e inespecíficas debido a interacciones de tipo Van der Waals.

Además del tipo de química de las fases estacionarias hay otros factores que afectan a la separación, como es el tamaño de partícula que, junto con el flujo de fase móvil, tiene un efecto directo sobre la eficacia cromatográfica según la ecuación de Van Deemter. Esta ecuación relaciona la velocidad lineal de la fase móvil con la eficacia de la columna para un determinado tamaño de partícula. Con el objetivo de mejorar la eficacia, en los últimos años se han 
desarrollado columnas cromatográficas con tamaño de partícula inferior a 2 $\mu \mathrm{m}$, frente a las tradicionales columnas HPLC de 3.5 y $5 \mu \mathrm{m}$. Estas columnas, denominadas UHPLC o de ultra alta resolución, aportan una mayor eficacia en un amplio rango de flujos elevados, a diferencia de las columnas HPLC cuyo rango de flujos óptimos es muy limitado. El hecho de permitir trabajar a flujos mayores sin afectar la eficacia, favorece la reducción de los tiempos de análisis. Además, al generar picos cromatográficos más estrechos también se incrementa la capacidad de picos de la columna.

La cromatografía UHPLC en fase reversa ha sido utilizada en los artículos científicos I y III presentados en los capítulos 2 y 3.

\subsubsection{Espectrometría de masas}

La espectrometría de masas es una técnica analítica que permite la separación de iones en base a una propiedad intrínseca de la materia ionizada: la relación masa/carga $(\mathrm{m} / \mathrm{z})$. Se trata de una técnica muy versátil y potente, habitualmente acoplada a cromatografía, que permite obtener información estructural, cualitativa y cuantitativa de las moléculas presentes en las muestras. Este acoplamiento ha supuesto un gran avance en las técnicas de análisis, y su potencial reside en el carácter bidimensional de separación que proporciona la cromatografía junto con la detección sensible y selectiva de la espectrometría de masas.

El espectrómetro de masas presenta tres componentes fundamentales: la fuente de ionización, el analizador de masas y el detector. A continuación, se describirán las dos primeras. 


\subsubsection{Fuentes de ionización}

El acoplamiento del sistema cromatográfico al espectrómetro de masas se realiza mediante una interfase. En el caso de GC, dada la naturaleza gaseosa de la técnica, esta interfase consiste en una línea de transferencia caliente (entre $200-350^{\circ} \mathrm{C}$ ) que contiene la parte final de la columna cromatográfica en su interior y que la conecta con la fuente de ionización. No obstante, en el caso de LC, son las propias interfases las que actúan como fuente de ionización.

\section{Ionización en GC}

\section{Ionización electrónica (EI)}

La ionización electrónica es la fuente más comúnmente empleada en el acoplamiento GC-MS. Se trata de una fuente robusta, reproducible y universal que opera en condiciones de vacío y cuyo mecanismo de ionización se basa en el bombardeo de las moléculas con un haz de electrones de alta energía (habitualmente $70 \mathrm{eV}$ ) producidos desde un filamento caliente. Estos electrones son acelerados mediante un campo eléctrico, interaccionan con las moléculas y les extraen un electrón. En este proceso, las moléculas adquieren un exceso energético que eliminan mediante movimientos vibracionales, rotacionales y de reordenación molecular, lo que provoca la fragmentación de las mismas.

La principal ventaja de la EI reside en la disponibilidad comercial de librerías de espectros de masas, lo que facilita la identificación de compuestos. No obstante, presenta una serie de inconvenientes. Debido a la elevada energía involucrada en el proceso de ionización, ciertos tipos de moléculas son 
altamente fragmentadas provocando, incluso, la pérdida total o parcial del ion molecular en el espectro de masas. Ante estas circunstancias, la identificación de compuestos -especialmente los que no están incluidos en las librerías espectrales- supone un reto por la complejidad en la interpretación del espectro y por la falta de información de la molécula intacta.

\section{Ionización química (CI)}

La ionización química es una técnica de ionización basada en la interacción de iones reactivos de baja energía -provenientes de un gas ionizado mediante el bombardeo con un haz de electrones de alta energía- con las moléculas de los analitos. El proceso de ionización en CI puede implicar la transferencia de un electrón, un protón u otra especie cargada. A diferencia de la EI, la presencia de una atmósfera rica en moléculas neutras de gas reactivo reduce la energía de los electrones emitidos y de las moléculas ionizadas, aportando a esta técnica un carácter de ionización suave.

La ionización química puede dar lugar a una especie positiva y/o negativa, y ambos procesos pueden ocurrir simultáneamente. En modo positivo, la ionización suele producirse mediante la transferencia de un protón, aunque también se producen otras reacciones ion-molécula como la formación de aductos con los iones reactivos, la extracción de hidruro o la transferencia de carga. En modo negativo, puede producirse la reacción ion-molécula de desprotonación, aunque los principales mecanismos son la captura de electrón por resonancia, la captura de electrón disociativa o la formación de pares iónicos. Al igual que en EI, la fragmentación de las moléculas dependerá de la energía involucrada en el proceso de ionización.

La principal ventaja de la CI reside en la selectividad y en la alta sensibilidad 
que presenta en modo negativo para la determinación de compuestos electrofílicos. Además, el carácter suave de ionización permite obtener, en algunos casos, información sobre la molécula prácticamente intacta, facilitando la identificación de compuestos desconocidos. Sin embargo, es una técnica poco popular ya que, a diferencia de EI, no es universal, no dispone de librerías espectrales y es poco robusta y reproducible.

\section{Ionización química a presión atmosférica (APCI)}

La ionización química a presión atmosférica combina la universalidad de la EI con el carácter de ionización suave de la CI. Se trata de una fuente de ionización a presión atmosférica (API) cuyo mecanismo se inicia con la ionización de un gas reactivo (generalmente $\mathrm{N}_{2}$ ) mediante una descarga eléctrica generada en un pin, originando un plasma de nitrógeno por efecto corona. Como puede observarse en la figura 2 , este plasma ioniza los analitos mediante dos mecanismos simultáneos y competitivos entre ellos: la transferencia de carga y/o la protonación (en presencia de humedad). La ionización mediante transferencia de carga origina normalmente el ion molecular $\left(\mathrm{M}^{+\cdot}\right)$ como pico base del espectro, mientras que la molécula protonada $\left([\mathrm{M}+\mathrm{H}]^{+}\right)$suele ser la más abundante en la ionización por protonación. Dada la dificultad de controlar las condiciones de humedad en la fuente, en moléculas que presentan algún grupo protonable, es común observar en el espectro de masas ambos iones. Para favorecer las condiciones de protonación se pueden añadir en la fuente de APCI modificadores próticos como agua, metanol o isopropanol, de modo que la abundancia de $[\mathrm{M}+\mathrm{H}]^{+}$ aumenta para aquellos compuestos cuya afinidad prótica es superior a la del modificador. 


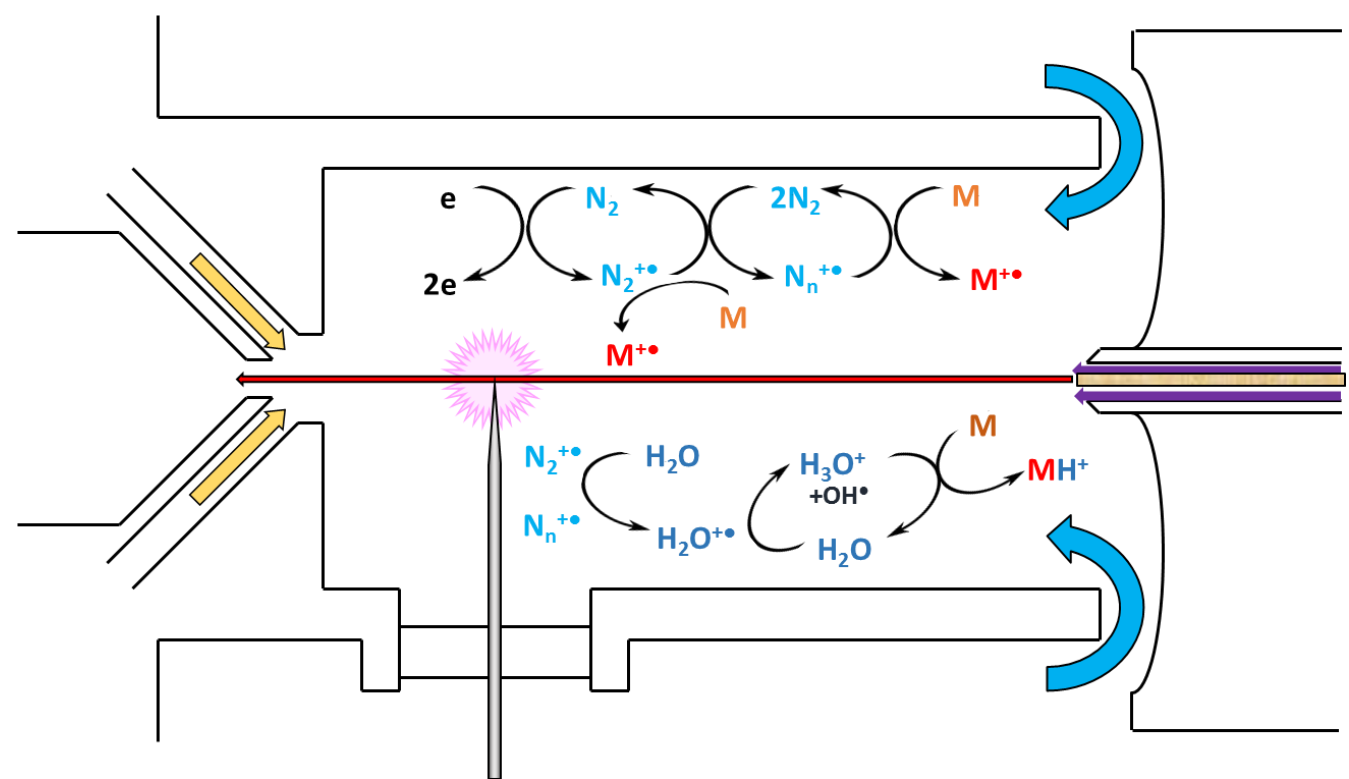

Figura 2: Esquema de la fuente APCI. Las flechas naranjas, azules y moradas indican los flujos de $\mathrm{N}_{2}$ provenientes del gas de cono, gas auxiliar y gas de make up, respectivamente. La flecha roja corresponde al eluato de la columna.

El potencial de la fuente APCI reside en la escasa o nula fragmentación producida durante el proceso de ionización. Pese a la ausencia, de momento, de amplias librerías espectrales, el carácter de ionización suave facilita la identificación de compuestos desconocidos ya que mantiene la información de la estructura molecular prácticamente intacta. Además, simplifica la interpretación de los espectros de masas, ya que la información estructural obtenida tras experimentos de masas en tándem (MS/MS) proviene, en la mayoría de casos, de $\mathrm{M}^{+\cdot}$ y/o $[\mathrm{M}+\mathrm{H}]^{+}$como iones precursores. Este hecho supone una gran ventaja en el desarrollo de métodos target o dirigidos mediante el uso de MS/MS, ya que al ser más abundantes y selectivos los iones precursores, las transiciones adquiridas serán también más sensibles y específicas. 


\section{$\underline{\text { Ionización en LC }}$}

\section{Ionización mediante electrospray (ESI)}

La interfase de ionización electrospray es una técnica API ampliamente utilizada en el acoplamiento LC-MS, que se basa en la producción de un aerosol formado por pequeñas gotas cargadas bajo la influencia de un campo eléctrico. Para ello, los analitos disueltos en la fase móvil pasan a través de un capilar cuya punta se encuentra a una diferencia de potencial de unos $3 \mathrm{kV}$ respecto al contraelectrodo. Esta diferencia de potencial produce un intenso campo eléctrico capaz de dispersar el eluato y generar un aerosol de pequeñas gotas cargadas ayudado por un gas de nebulización. Al atravesar la región a presión atmosférica, la mayor parte de las moléculas de disolvente se evaporan. Debido a los flujos utilizados en LC, el proceso de desolvatación se acelera mediante una corriente de nitrógeno caliente. A medida que se evapora el disolvente, las gotas van reduciendo su tamaño hasta que las fuerzas repulsivas entre los iones generados en su interior son capaces de superar las fuerzas cohesivas de tensión superficial, produciendo la ruptura de la gota y originando iones en fase gaseosa. Dado el carácter de ionización suave, los espectros obtenidos suelen estar dominados por las moléculas protonadas o desprotonadas, según la ionización se efectúe en modo positivo o negativo, respectivamente.

La interfase ESI utilizada en los artículos científicos I y III presenta la configuración Z-Spray. A diferencia de las fuentes ESI convencionales, en las que la trayectoria de los iones desde el capilar hasta el espectrómetro de masas es una línea recta, la configuración Z-Spray presenta una trayectoria en forma de $\mathrm{Z}$, como bien indica su nombre, permitiendo que únicamente las moléculas 
ionizadas fluyan hacia el espectrómetro de masas mediante la aplicación de potenciales. De este modo, se reduce la señal de fondo y se mejora la relación señal/ruido $(\mathrm{S} / \mathrm{N})$.

Uno de los puntos fuertes de la interfase ESI es la posibilidad de generar iones policargados. Esta característica ha facilitado el análisis de macromoléculas biológicas mediante MS, pudiendo extender el rango de masas del instrumento en un factor equivalente al número de cargas de la molécula del analito. Además, es una técnica muy versátil ya que permite el análisis de compuestos termolábiles, con un amplio rango de pesos moleculares y también de polaridades: desde compuestos iónicos a otros con cierto carácter lipofílico. Sin embargo, el principal inconveniente que presenta es el elevado efecto que tiene la presencia de compuestos de la matriz sobre la eficacia en la ionización.

\subsubsection{Analizadores de masas}

\section{Cuadrupolo simple (Q)}

El filtro de masas cuadrupolar o cuadrupolo simple consta de cuatro superficies hiperbólicas paralelas entre ellas a las que se les aplica una corriente continua (DC) y un voltaje de radiofrecuencia (RF). La combinación de ambos potenciales a cada par de superficies opuestas genera un campo eléctrico oscilante de alta frecuencia que permite establecer trayectorias estables, a través de la geometría del cuadrupolo, para iones con una determinada relación masa/carga $(\mathrm{m} / \mathrm{z})$. De este modo, el resto de iones con relación $\mathrm{m} / \mathrm{z}$ distinta a la estabilizada por los potenciales se pierden a lo largo del filtro de masas cuadrupolar. 
Este tipo de analizador de masas, por su modo de funcionamiento, permite adquirir en Full Scan, es decir, realizar barridos completos de iones en un determinado rango de $\mathrm{m} / \mathrm{z}$, obteniendo así el espectro de masas completo; o, por otra parte, trabajar en modo Selected Ion Monitoring (SIM), en el que se monitorizan únicamente unos iones previamente seleccionados, aumentando la sensibilidad y selectividad de la adquisición.

\section{Triple cuadrupolo (QqQ)}

El analizador de masas de triple cuadrupolo consiste en la combinación de dos cuadrupolos $\left(\mathrm{Q}_{1}, \mathrm{Q}_{2}\right)$ acoplados en serie a otro (q, habitualmente hexapolo $\mathrm{u}$ octapolo) situado entre ellos, que normalmente actúa como celda de colisión. Se trata de un sistema muy versátil ya que permite la adquisición en diferentes modos, tanto en espectrometría de masas simple (MS) como en tándem (MS/MS). Sin embargo, es la configuración MS/MS la que ofrece todo su potencial, aportando gran sensibilidad y selectividad; y proporcionando información estructural adicional de los compuestos por medio de la celda de colisión, que produce la fragmentación de los iones mediante la disociación por colisión inducida (CID) con un gas no reactivo (Ar, He o $\mathrm{N}_{2}$ ). Existen diferentes modos de adquisición en un QqQ (ver Tabla 1), aunque el más interesante en análisis cuantitativo es el modo Selected Reaction Monitoring (SRM). En este modo, el $\mathrm{Q}_{1}$ aísla un ion precursor previamente seleccionado, se fragmenta en la celda de colisión y el $\mathrm{Q}_{2}$ aísla un ion producto previamente establecido, mejorando así la selectividad y la relación S/N del método. 
Tabla 1: Modos de adquisición en analizadores de masas de triple cuadrupolo.

\begin{tabular}{|c|c|c|c|c|}
\hline MODO & $\mathbf{Q}_{1}$ & $\mathbf{q}$ & $\mathbf{Q}_{2}$ & APLICACIÓN \\
\hline Full Scan & - & - & Scan & Conocer la ionización de la molécula \\
\hline SIM & - & - & SIM & $\begin{array}{l}\text { Adquirir un ion específico de la } \\
\text { molécula }\end{array}$ \\
\hline $\begin{array}{l}\text { Product } \\
\text { Ion Scan }\end{array}$ & SIM & CID & Scan & $\begin{array}{l}\text { Obtener información estructural de la } \\
\text { molécula }\end{array}$ \\
\hline SRM & SIM & CID & SIM & $\begin{array}{l}\text { Adquirir una reacción CID (métodos } \\
\text { cuantitativos) }\end{array}$ \\
\hline $\begin{array}{l}\text { Precursor } \\
\text { Ion Search }\end{array}$ & Scan & CID & SIM & $\begin{array}{l}\text { Obtener información de compuestos } \\
\text { que presentan fragmentos idénticos }\end{array}$ \\
\hline $\begin{array}{l}\text { Neutral } \\
\text { Loss } \\
\text { Search }\end{array}$ & Scan & CID & Scan & $\begin{array}{l}\text { Obtener información de compuestos } \\
\text { que presentan pérdidas neutras por } \\
\text { fragmentación idénticas }\end{array}$ \\
\hline
\end{tabular}

El sistema instrumental Xevo TQ-S utilizado en los artículos científicos I, II y III, consiste en un triple cuadrupolo que dispone del sistema de transferencia de iones StepWave. Este sistema consiste en una serie de electrodos anulares apilados que se combinan para formar una lente de transmisión de iones fuera del eje (en forma de escalón). Este diseño permite eliminar los compuestos no ionizados que pudiesen entrar al sistema mediante el vacío, mientras que aquellos ionizados entran al sistema conducidos por una serie de potenciales aplicados a los electrodos. La principal ventaja que presenta es la mejora de la relación $\mathrm{S} / \mathrm{N}$ al eliminar parte de la señal de fondo, especialmente en matrices complejas. 


\section{Híbrido cuadrupolo - tiempo de vuelo (QTOF)}

El analizador de masas QTOF combina el filtro de masas cuadrupolar con la alta resolución del analizador TOF. El funcionamiento del TOF se basa en la separación de los iones en función del tiempo que tardan en atravesar un tubo de vuelo. Al entrar al analizador de masas, los iones son sometidos a un pulso de voltaje que los acelera a través del tubo de vuelo. Partiendo del principio de conservación de la energía cinética de los iones - adquirida al ser previamente acelerados a través de la fuente de ionización -, estos se separan a diferentes velocidades, que son inversamente proporcionales a la raíz cuadrada de su relación $\mathrm{m} / \mathrm{z}$. De este modo, para cada pulso de voltaje se obtiene un espectro de masas completo. El instrumento TOF requiere estos pulsos de voltaje para transferir de manera simultánea e instantánea los paquetes de iones, así como evitar el solapamiento entre éstos, ya que la frecuencia en la que son emitidos está determinada por el tiempo que tarda el último ion en llegar al detector.

Para optimizar la transferencia de iones, minimizar la dispersión espacial de los mismos y, por ende, aumentar la sensibilidad y determinar con mayor precisión los tiempos de vuelo, los instrumentos TOF presentan, habitualmente, la configuración de aceleración ortogonal; como es el caso del sistema instrumental Xevo G2 QTOF utilizado en los artículos científicos I, III y IV. En esta configuración, el haz de iones proveniente de la fuente de ionización accede al analizador desde una dirección perpendicular al tubo de vuelo. Además, los instrumentos TOF de alta resolución suelen disponer de reflectrones. El reflectrón consiste en una serie de electrodos colocados al final del tubo de vuelo que corrige los efectos de la dispersión espacial y energética iniciales. Su funcionamiento se basa en la reducción de la velocidad de los 
iones que entran al dispositivo mediante un campo eléctrico repelente, y su posterior aceleración hacia el detector. De esta manera, los iones con la misma relación $\mathrm{m} / \mathrm{z}$ pero con velocidades iniciales diferentes, se reenfocan para ser detectados simultáneamente. El sistema instrumental Xevo G2 QTOF utilizado en esta tesis, presenta la configuración en V (con un reflectrón), lo que permite duplicar la distancia de vuelo y, por tanto, el poder de resolución.

El hecho de combinar el cuadrupolo con el TOF permite trabajar en modos de adquisición como Full Spectrum, Product Ion Scan y Data Independent Acquisition $\left(\mathrm{MS}^{\mathrm{E}}\right.$, en el caso del instrumento utilizado en esta tesis). Para los dos últimos modos de adquisición, el QTOF dispone de la celda de colisión CID. En el modo Product Ion Scan, el ion precursor se aísla en el cuadrupolo, se fragmenta en la celda de colisión a unas energías determinadas y se detectan todos los iones producto en el TOF. En el modo $\mathrm{MS}^{\mathrm{E}}$, por su parte, los iones precursores no se aíslan, pero la celda de colisión actúa secuencialmente como elemento de transmisión (función de baja energía, LE) y como celda de colisión en la cual se aplica una rampa de potencial (función de alta energía, $\mathrm{HE}$ ). En este último modo, se adquieren en una única inyección ambas funciones, obteniendo información conjunta de las moléculas "intactas" y fragmentadas, permitiendo el análisis retrospectivo.

\subsection{Estrategias analíticas para el control alimentario}

En el apartado anterior se han descrito las diferentes opciones instrumentales utilizadas a lo largo de esta tesis ya que, desde el punto de vista analítico, resulta crucial conocer el potencial de cada instrumento y aprovecharlo para desarrollar estrategias que permitan mejorar el alcance de los análisis. A 
continuación se describen brevemente aquellas utilizadas a lo largo de esta tesis.

\section{Análisis pre-target}

Se trata de un modo de análisis en el que se definen previamente los compuestos de interés y se optimizan sus condiciones de medida con la finalidad de detectarlos, identificarlos $\mathrm{y}$, normalmente, cuantificarlos en las matrices de estudio. Para esta estrategia es habitual la utilización de analizadores de masas QqQ en modo MS/MS.

Las principales ventajas de este tipo de análisis residen en la posibilidad de optimización de todo el proceso analítico mediante el uso de patrones de referencia, incrementando así la sensibilidad del método. Además, este facilita el procesamiento de datos dado que se adquiere un número limitado de transiciones.

Por otra parte, el principal inconveniente de este modo de análisis se encuentra precisamente en la limitación a los compuestos incluidos en el método. El análisis pre-target, al centrar su alcance en una serie definida de compuestos, no permite el análisis retrospectivo, es decir, el que se realiza a partir de datos adquiridos en un análisis anterior, con el fin de investigar otros compuestos de interés no considerados inicialmente.

\section{Screening de amplio alcance}

La alternativa al análisis pre-target pasa por la adquisición en modo full-scan o full spectrum. Este tipo de adquisición permite llevar a cabo estrategias de screening de amplio alcance ya que, al no requerir de la preselección de $\mathrm{m} / \mathrm{z}$ determinadas se evita la limitación de compuestos a analizar y permite el 
análisis retrospectivo. Habitualmente, este tipo de análisis se lleva a cabo con espectrómetros de masas de alta resolución, como QTOF o QOrbitrap, que aportan espectros completos medidos con elevada exactitud de masa.

Sin embargo, este modo de análisis presenta el principal inconveniente de generar gran cantidad de datos, muchos de ellos irrelevantes desde el punto de vista analítico, que dificultan el procesamiento de los mismos. Por ello, es necesario establecer aproximaciones que filtren los datos correspondientes a los compuestos de interés. Basándonos en la nomenclatura utilizada por Hernández et al. [22], podemos distinguir tres tipos de aproximaciones para abordar el tratamiento de los datos:

- Target screening: se refiere al tipo de screening en el que, posteriormente a la adquisición de los datos, se seleccionan unos compuestos a investigar para los cuales se posee su información espectral y cromatográfica obtenida a partir de los respectivos patrones de referencia.

- Suspect screening: a diferencia del target screening, no se posee información espectral ni cromatográfica previa, dada la ausencia de patrones de referencia, y únicamente se dispone de información molecular.

- Non-target screening: es el tipo de screening en el que, mediante algoritmos de deconvolución espectral, se encuentran picos cromatográficos presentes en la muestra para la posterior elucidación e identificación de aquellos que puedan resultar relevantes analíticamente. En otras palabras, se investiga la presencia de compuestos para los cuales no se dispone de información espectral, ni cromatográfica, ni molecular previa. Esta aproximación no se ha utilizado en los trabajos presentados en la presente tesis. 


\subsection{Tratamiento de muestra en matrices de acuicultura.}

La aplicación de la química analítica en el campo de la acuicultura implica el análisis de una gran variedad de matrices de diferente naturaleza y complejidad, desde ingredientes de los piensos a pescado. Además, las propiedades físico-químicas de los analitos también son muy amplias, lo que dificulta encontrar métodos que funcionen correctamente para todas las combinaciones matriz/analito. Estos factores, junto a la baja concentración en la que suelen encontrarse los analitos en las muestras de análisis, hacen necesaria la aplicación de tratamientos de muestra eficaces que permitan la obtención de extractos limpios, compatibles con los sistemas instrumentales, para proporcionar resultados fiables.

El análisis de muestras sólidas requiere, en primer lugar, la extracción de los compuestos de interés de la matriz mediante el uso de disolventes orgánicos $\mathrm{y}$, en segundo lugar, la purificación o clean up del extracto para reducir o eliminar componentes de la matriz que puedan interferir en el análisis. Algunos de los sistemas de tratamiento de muestra tradicionalmente utilizados en el análisis de muestras de acuicultura son el Soxhlet, la extracción con fluidos supercríticos (SFE), la extracción asistida por microondas (MAE), la extracción mediante ultrasonidos (USE), la extracción líquida presurizada (PLE) y la cromatografía por permeación en gel (GPC) [23]. Sin embargo, estos sistemas son costosos en cuanto a tiempo y volumen de disolventes, como el Soxhlet; o en cuanto a equipamiento, en el caso de SFE, MAE, PLE y GPC. Debido al creciente interés en desarrollar métodos más rápidos, económicos, simples y verdes, la aplicación de QuEChERS goza de gran popularidad en la actualidad. 
Desde que fue diseñado en 2003 para la extracción de pesticidas en frutas y vegetales [24], basado en la extracción con acetonitrilo, el método QuEChERS original se ha sometido a modificaciones que lo convierten en un método versátil, adaptable a matrices y analitos de diversa naturaleza, así como a las características instrumentales. Entre las modificaciones desarrolladas, cabe destacar, en el análisis de residuos de plaguicidas, dos de ellas que mejoran la extracción del método original sobre pesticidas $\mathrm{pH}$-dependientes: el método 15662 del Comité Europeo de Normalización (CEN), que emplea tampón de citrato [25]; y el método oficial 2007.01 de la Asociación de Comunidades Analíticas (AOAC), que usa acetato sódico como tampón [26]. Pese a ser métodos de referencia en el análisis de plaguicidas en frutas y verduras, el uso de métodos basados en QuEChERS se ha extendido en la determinación de otros contaminantes como PAHs, PCBs o difeniléteres polibromados (PBDEs) en matrices de acuicultura [27, 28], cambiando, en algunos casos, el extractante a acetato de etilo para favorecer la extracción de los analitos [29, 30].

La versatilidad de QuEChERS no sólo reside en la etapa de extracción. Actualmente, existen diferentes adsorbentes que facilitan la optimización del proceso de clean up en función de las características de la matriz y de los analitos. De hecho, en el método original, la etapa de purificación se realiza mediante el uso de $\mathrm{MgSO}_{4}$ anhidro y amina primaria-secundaria (PSA). Sin embargo, ahora es habitual encontrar aplicaciones en las que también se utiliza carbón negro grafitizado (GCB), $\mathrm{C}_{18}$ o materiales de última generación como Z-Sep, que permiten obtener extractos más limpios [27, 31-33].

A pesar de la efectividad del tratamiento de muestra para reducir el efecto matriz, es decir, el efecto que tienen los compuestos coextraídos de la matriz 
sobre la respuesta de los analitos, éste puede ser notorio en algunos tipos de muestras. El efecto matriz puede originar errores de cuantificación y detección, así como afectar la sensibilidad, reproducibilidad y linealidad del método. Por estos motivos, es necesario evaluar cómo afecta la presencia de la matriz en los compuestos a determinar para así definir las estrategias que lo corrijan.

\subsection{Estrategias de corrección del efecto matriz.}

El mecanismo de supresión/exaltación iónica en cromatografía acoplada a espectrometría de masas puede variar en función del tipo de cromatografía e ionización.

Por un lado, en LC-MS con fuente de ionización ESI, se piensa que el efecto matriz se produce en la fuente de ionización y se debe probablemente a un proceso de competición entre los analitos y los componentes de la matriz coeluídos [34], bien por acceder a la superficie de las pequeñas gotas donde se produce el paso a fase gas - a mayor fuerzas atractivas para mantener las gotas, menor eficiencia de ionización [35] -, o bien porque la concentración de compuestos orgánicos es superior a $10^{-5} \mathrm{M}$, fijando esta concentración como máxima para obtener una ionización eficiente $[34,36]$. En este caso es común observar supresión de señal.

Por otro lado, en GC, y especialmente en combinación con la fuente EI, el efecto matriz se produce principalmente en el sistema de inyección y/o cromatográfico debido a la interacción de la matriz con los puntos activos del liner y de la columna cromatográfica. Los componentes de la matriz tienden a 
bloquear estos puntos activos, reduciendo así las pérdidas de analitos causadas por la adsorción i/o degradación en éstos y, por tanto, obteniendo una respuesta mayor (exaltación de señal) en los extractos en comparación con los estándares de solventes [37-39].

Independientemente del mecanismo de supresión/exaltación de la señal, existen diferentes estrategias comunes para eliminar o compensar el efecto matriz.

\section{Estrategias en el proceso de cuantificación}

Tienen como objetivo compensar el efecto que pueden producir los interferentes de matriz en el proceso de análisis. Entre las estrategias más utilizadas se encuentran: el uso de respuesta relativa, el calibrado en matriz y el método de adiciones estándar.

El uso de la respuesta relativa consiste en la utilización de un patrón interno, el cual debe estar ausente en las muestras y debe presentar un comportamiento similar al de los analitos estudiados. Su adición puede realizarse sobre la muestra cruda con el objetivo de corregir posibles pérdidas en el proceso de tratamiento de muestra y el efecto matriz (surrogate), o adicionarse al extracto final con el fin de corregir el efecto matriz y posibles variaciones en la inyección (internal standard, IS). La dificultad de encontrar un patrón interno que esté ausente en las muestras y presente un efecto matriz similar (además del comportamiento durante el tratamiento de muestra, en el caso de ser adicionado como surrogate) al de los compuestos de interés dificulta esta aproximación. No obstante, existe la posibilidad de utilizar patrones internos marcados isotópicamente (Stable Isotopically Labelled Internal Standards, SIL-IS), es decir, compuestos estructuralmente iguales a los analitos de interés 
- por lo que su comportamiento cromatográfico y espectrométrico es prácticamente idéntico al compuesto nativo - a los que se les sustituyen algunos átomos por sus respectivos isótopos. El principal requisito que deben cumplir los SIL-IS es que contengan suficientes átomos sustituidos por sus correspondientes isótopos para evitar el solapamiento entre la distribución isotópica del compuesto marcado con el nativo. En esta aproximación, la respuesta relativa entre la señal del compuesto de interés y la del SIL-IS - este último adicionado siempre a una concentración fija en todas las muestras - se utiliza para cuantificar la concentración del primero corrigiendo las variaciones debidas a la matriz. Aunque el uso de SIL-IS es la opción más adecuada, presenta como principales inconvenientes la limitada disponibilidad comercial y su elevado precio.

El uso del calibrado en matriz es otra aproximación ampliamente utilizada para la corrección del efecto matriz. Esta opción consiste en la preparación de curvas de calibrado sobre extracto blanco de la matriz, sometido al mismo tratamiento que las muestras a analizar, para cuantificar los analitos. De este modo, se compensa el efecto matriz de las muestras con el de los patrones de cuantificación. El principal requisito de esta alternativa es disponer de muestras blanco representativas ya que, de no serlo, se puede incurrir en errores de cuantificación debido a diferencias en la supresión/exaltación de la señal.

Por último, aunque menos utilizadas, las adiciones estándar son una posibilidad para corregir el efecto matriz. Esta alternativa consiste en añadir cantidades crecientes de analitos de interés a una cantidad fija de muestra. Esta aproximación presenta dos limitaciones principales: un aumento considerable del tiempo de análisis, ya que se necesitarán varias inyecciones por muestra; 
y la necesidad de prever el nivel de concentración esperado para poder realizar las adiciones correctas.

\section{Estrategias de reducción de la cantidad de matriz}

Tienen como objetivo evitar el efecto matriz mediante la reducción de interferentes inyectados en el sistema cromatográfico.

La opción más utilizada es la aplicación de etapas de purificación. Actualmente, estas etapas suelen consistir en una extracción en fase sólida (SPE) o extracción en fase sólida dispersiva (d-SPE), habitual en el método QuEChERS, debido a la gran variedad de adsorbentes disponibles para obtener una purificación adecuada. Aunque la SPE permite eliminar interferentes y realizar una preconcentración de los analitos, ésta requiere de mayores volúmenes de extracto a tratar, así como un aumento del tiempo de análisis, a diferencia de los métodos QuEChERS. Además, el uso de técnicas de purificación en métodos multianalito presenta limitaciones debido a las posibles pérdidas de compuestos dada la variedad de propiedades físicoquímicas de los mismos.

Por ello, una de las soluciones más sencillas que se adoptan en métodos multianalito es la dilución de los extractos. Con esta aproximación se consigue, sin producirse la pérdida de analitos, reducir la carga de matriz inyectada al sistema cromatográfico. Sin embargo, esta alternativa está muy condicionada por la sensibilidad del método. 
En la presente Tesis Doctoral se han utilizado técnicas basadas en cromatografía acoplada a espectrometría de masas para la determinación de compuestos endógenos y exógenos en matrices de acuicultura.

En el capítulo 2 se ha desarrollado metodología cuantitativa y cualitativa para el análisis de contaminantes orgánicos. El artículo científico I se ha centrado en el screening, utilizando UHPLC y GC con fuentes API acopladas al analizador (Q)TOF. A partir de los resultados obtenidos, se desarrolló un método multiresiduo basado en GC-APCI-QqQ MS/MS, focalizado en la determinación de PAHs, que se detalla en el artículo científico II.

En el capítulo 3, se detalla el método desarrollado para la determinación de chrlopyrifos-methyl, pirimiphos-methyl y sus principales metabolitos mediante UHPLC-QqQ MS/MS, en muestras de pez cebra y de tejidos de salmón. El objetivo final del artículo científico III es contar con un método avanzado para determinar la cinética de acumulación y eliminación de los plaguicidas de estudio y sus metabolitos principales en el tejido de los peces.

Por último, en el capítulo 4, compuesto por el artículo IV, se indaga en las características de la fuente APCI como alternativa para la caracterización de VLC-PUFA.

Los métodos analíticos presentados se han desarrollado con el fin de ampliar el conocimiento sobre un campo de creciente interés, como es la acuicultura. Además, a lo largo de este trabajo, se corrobora el potencial de la fuente APCI en GC para dar solución a problemas concretos desde un punto de vista espectrométrico. 


\subsection{Referencias}

1. United Nations, Department of Economic and Social Affairs, Population Division (2017) World Population Prospects: The 2017 revision

2. FAO (2018) El estado mundial de la pesca y la acuicultura 2018. Cumplir los objetivos de desarrollo sostenible. Roma. Licencia: CC BY-NC-SA 3.0 IGO

3. Shepherd CJ, Jackson AJ (2013) Global fishmeal and fish-oil supply: Inputs, outputs and markets. J Fish Biol 83:1046-1066. doi: $10.1111 /$ jfb. 12224

4. Monroig Ó, Navarro JC, Tocher DR (2011) Long-Chain Polyunsaturated Fatty Acids in fish: Recent advances on desaturases and elongases involved in their biosynthesis. Av en Nutr Acuícola XI Memorias del Décimo Prim Simp Int Nutr Acuícola, 23-25 Noviembre, San Nicolás los Garza, N L, México 257-283

5. Janssen CIF, Kiliaan AJ (2014) Long-chain polyunsaturated fatty acids (LCPUFA) from genesis to senescence: The influence of LCPUFA on neural development, aging, and neurodegeneration. Prog Lipid Res 53:1-17. doi: 10.1016/j.plipres.2013.10.002

6. Kawashima A, Watanabe S, Iwakiri R, Honda K (2009) Removal of dioxins and dioxin-like PCBs from fish oil by countercurrent supercritical CO2extraction and activated carbon treatment. Chemosphere 75:788-794. doi: 10.1016/j.chemosphere.2008.12.057 
7. Maes J, De Meulenaer B, Van Heerswynghels P, De Greyt W, Eppe G, De Pauw E, Huyghebaert A (2005) Removal of dioxins and PCB from fish oil by activated carbon and its influence on the nutritional quality of the oil. JAOCS, J Am Oil Chem Soc 82:593-597. doi: $10.1007 / \mathrm{s} 11746-005-1114-1$

8. Oterhals Å, Solvang M, Nortvedt R, Berntssen MHG (2007) Optimization of activated carbon-based decontamination of fish oil by response surface methodology. Eur J Lipid Sci Technol 109:691-705. doi: 10.1002/ejlt.200700083

9. Berntssen MHG, Olsvik PA, Torstensen BE, Julshamn K, Midtun T, Goksøyr A, Johansen J, Sigholt T, Joerum N, Jakobsen J V., Lundebye AK, Lock EJ (2010) Reducing persistent organic pollutants while maintaining long chain omega-3 fatty acid in farmed Atlantic salmon using decontaminated fish oils for an entire production cycle. Chemosphere 81:242-252. doi: 10.1016/j.chemosphere.2010.06.031

10. Nácher-Mestre J, Serrano R, Benedito-Palos L, Navarro JC, López FJ, Pérez-Sánchez J (2009) Effects of fish oil replacement and re-feeding on the bioaccumulation of organochlorine compounds in gilthead sea bream (Sparus aurata L.) of market size. Chemosphere 76:811-817. doi: 10.1016/j.chemosphere.2009.04.046

11. Berntssen MHG, Julshamn K, Lundebye A-K (2010) Chemical contaminants in aquafeeds and Atlantic salmon (Salmo salar) following the use of traditional- versus alternative feed ingredients. Chemosphere 78:637-646. doi: 10.1016/j.chemosphere.2009.12.021 
12. Nácher-Mestre J, Serrano R, Portolés T, Berntssen MHG, PérezSánchez J, Hernández F (2014) Screening of pesticides and polycyclic aromatic hydrocarbons in feeds and fish tissues by gas chromatography coupled to high-resolution mass spectrometry using atmospheric pressure chemical ionization. J Agric Food Chem 62:2165-2174. doi: $10.1021 /$ jf405366n

13. Nácher-Mestre J, Serrano R, Benedito-Palos L, Navarro JC, López FJ, Kaushik S, Pérez-Sánchez J (2010) Bioaccumulation of polycyclic aromatic hydrocarbons in gilthead sea bream (Sparus aurata L.) exposed to long term feeding trials with different experimental diets. Arch Environ Contam Toxicol 59:137-46. doi: 10.1007/s00244-0099445-1

14. (2002) Reglamento (CE) $\mathrm{N}^{\mathrm{o}} 178 / 2002$ del parlamento y del consejo de 28 de enero de 2002 por el que se establecen los principios y los requisitos generales de la legislación alimentaria.

15. Council of Europe (1976) European Convention for the Protection of Animals kept for Farming Purposes. Strasbourg

16. European Commission (2017) Analytical quality control and method validation procedures for pesticide residues analysis in food and feed; document no. SANTE/11813/2017

17. Hernández F, Ibáñez M, Portolés T, Cervera MI, Sancho J V., López FJ (2014) Advancing Towards Universal Screening for Organic Pollutants in Waters. J Hazard Mater 282:86-95. doi: 10.1016/j.jha zmat.2014.08.006 
18. Poole CF, Poole SK (1991) Chromatography today. Elsevier

19. McNair HM, Miller JM (1998) Basic gas chromatography. WileyInterscience

20. Grob RL, Barry EF (2004) Modern practice of gas chromatography, 4th ed. Wiley-Interscience

21. Godula M, Hajšlová J, Alterová K (1999) Pulsed splitless injection and the extent of matrix effects in the analysis of pesticides. HRC J High Resolut Chromatogr 22:395-402. doi: 10.1002/(SICI)1521-4168(1999 0701)22:7<395::AID-JHRC395>3.0.CO;2-O

22. Hernández F, Sancho J V, Ibáñez M, Abad E, Portolés T, Mattioli L (2012) Current use of high-resolution mass spectrometry in the environmental sciences. Anal Bioanal Chem 403:1251-64. doi: $10.1007 / \mathrm{s} 00216-012-5844-7$

23. Plaza-Bolaños P, Frenich AG, Vidal JLM (2010) Polycyclic aromatic hydrocarbons in food and beverages. Analytical methods and trends. J Chromatogr A 1217:6303-6326. doi: 10.1016/j.chroma.2010.07.079

24. Anastassiades M, Lehotay SJ, Štajnbaher D, Schenck FJ (2003) Fast and easy multiresidue method employing acetonitrile extraction/partitioning and "dispersive solid-phase extraction" for the determination of pesticide residues in produce. J AOAC Int 86:412431

25. Payá P, Anastassiades M, Mack D, Sigalova I, Tasdelen B, Oliva J, Barba A (2007) Analysis of pesticide residues using the Quick Easy 
Cheap Effective Rugged and Safe (QuEChERS) pesticide multiresidue method in combination with gas and liquid chromatography and tandem mass spectrometric detection. Anal Bioanal Chem 389:16971714. doi: 10.1007/s00216-007-1610-7

26. Lehotay SJ, Maštovská K, Lightfield AR (2005) Use of buffering and other means to improve results of problematic pesticides in a fast and easy method for residue analysis of fruits and vegetables. J AOAC Int 88:615-629

27. Sapozhnikova Y, Lehotay SJ (2013) Multi-class, multi-residue analysis of pesticides, polychlorinated biphenyls, polycyclic aromatic hydrocarbons, polybrominated diphenyl ethers and novel flame retardants in fish using fast, low-pressure gas chromatography-tandem mass spectrometry. Anal Chim Acta 758:80-92. doi: 10.1016/j.aca .2012 .10 .034

28. Johnson YS (2012) Determination of Polycyclic Aromatic Hydrocarbons in Edible Seafood by QuEChERS-Based Extraction and Gas Chromatography-Tandem Mass Spectrometry. J Food Sci 77. doi: 10.1111/j.1750-3841.2012.02758.x

29. Kalachova K, Pulkrabova J, Cajka T, Drabova L, Hajslova J (2012) Implementation of comprehensive two-dimensional gas chromatography-time-of-flight mass spectrometry for the simultaneous determination of halogenated contaminants and polycyclic aromatic hydrocarbons in fish. Anal Bioanal Chem 403:2813-2824. doi: 10.1007/s00216-012-6095-3 
30. Kalachova K, Pulkrabova J, Drabova L, Cajka T, Kocourek V, Hajslova J (2011) Simplified and rapid determination of polychlorinated biphenyls, polybrominated diphenyl ethers, and polycyclic aromatic hydrocarbons in fish and shrimps integrated into a single method. Anal Chim Acta 707:84-91. doi: 10.1016/j.aca.2011 .09 .016

31. Łozowicka B, Rutkowska E, Jankowska M (2017) Influence of QuEChERS modifications on recovery and matrix effect during the multi-residue pesticide analysis in soil by GC/MS/MS and GC/ECD/NPD. Environ Sci Pollut Res 24:7124-7138. doi: 10.1007/s11356-016-8334-1

32. Rodríguez-González N, González-Castro M-J, Beceiro-González E, Muniategui-Lorenzo S (2017) Development of a matrix solid phase dispersion methodology for the determination of triazine herbicides in marine sediments. Microchem J 133:137-143. doi: 10.1016/j. microc.2017.03.022

33. Ramos S, Homem V, Santos L (2019) Development and optimization of a QuEChERS-GC-MS/MS methodology to analyse ultravioletfilters and synthetic musks in sewage sludge. Sci Total Environ 651:2606-2614. doi: 10.1016/j.scitotenv.2018.10.143

34. Tang L, Kebarle P (1993) Dependence of Ion Intensity in Electrospray Mass Spectrometry on the Concentration of the Analytes in the Electrosprayed Solution. Anal Chem 65:3654-3668. doi: 10.1021/ac00072a020 
35. King R, Bonfiglio R, Fernandez-metzler C, Miller-stein C, Olah T (2000) Mechanistic Investigation of Ionization Suppression in Electrospray Ionization. 305:

36. Kebarle P, Verkerk UH (2009) Electrospray: from ions in solution to ions in the gas phase, what we know now. Mass Spectrom Rev 28:898917. doi: 10.1002/mas.20247

37. Fujiyoshi T, Ikami T, Sato T, Kikukawa K, Kobayashi M, Ito H, Yamamoto A (2016) Evaluation of the matrix effect on gas chromatography - mass spectrometry with carrier gas containing ethylene glycol as an analyte protectant. J Chromatogr A 1434:136141. doi: 10.1016/j.chroma.2015.12.085

38. Maštovská K, Lehotay SJ, Anastassiades M (2005) Combination of analyte protectants to overcome matrix effects in routine $\mathrm{GC}$ analysis of pesticide residues in food matrixes. Anal Chem 77:8129-8137. doi: $10.1021 / \mathrm{ac} 0515576$

39. Cherta L, Portolés T, Beltran J, Pitarch E, Mol JGJ, Hernández F (2013) Application of gas chromatography-(triple quadrupole) mass spectrometry with atmospheric pressure chemical ionization for the determination of multiclass pesticides in fruits and vegetables. $\mathrm{J}$ Chromatogr A 1314:224-40. doi: 10.1016/j.chroma.2013.09.029 



\section{CAPÍTULO 2}

DETERMINACIÓN DE COMPUESTOS EXÓGENOS MEDIANTE EL USO DE ESPECTROMETRÍA DE MASAS CON ANALIZADOR DE CUADRUPOLOTIEMPO DE VUELO Y TRIPLE CUADRUPOLO 

CAPÍTULO 2: DETERMINACIÓN DE COMPUESTOS EXÓGENOS MEDIANTE EL USO DE ESPECTROMETRÍA DE MASAS CON ANALIZADOR DE CUADRUPOLO-TIEMPO DE VUELO Y TRIPLE CUADRUPOLO

\subsection{Introducción}

\subsection{Artículo científico I}

"Comprehensive strategy for pesticide residue analysis through the production cycle of gilthead sea bream and Atlantic salmon"

Chemosphere, 179, 242-253, 2017.

\subsection{Artículo científico II}

"Multi-class determination of undesirables in aquaculture samples by gas chromatography/tandem mass spectrometry with atmospheric pressure chemical ionization: A novel approach for polycyclic aromatic hydrocarbons" Talanta, 172, 109-119, 2017.

2.4. Discusión de los resultados obtenidos

2.5. Referencias 



\subsection{Introducción}

Como se ha expuesto en la introducción general de la tesis, la industria acuícola se enfrenta a un gran reto en términos de rentabilidad y sostenibilidad, planteando un nuevo escenario en el ámbito de la seguridad alimentaria.

Estudios previos en proyectos de la UE como "AQUAMAX" han demostrado que la sustitución de aceites y harinas de pescado por ingredientes vegetales en piensos de acuicultura, junto con técnicas comerciales de descontaminación, han supuesto un cambio en el perfil de los contaminantes presentes en los mismos. Por una parte, la sustitución de los ingredientes tradicionales se ha traducido en la disminución de contaminantes orgánicos persistentes (POPs), como dioxinas y PCBs, en los peces de cultivo [1, 2]. Sin embargo, también ha derivado en el incremento de los niveles de contaminantes relacionados con el tratamiento térmico de los ingredientes vegetales, como los hidrocarburos policíclicos aromáticos (PAHs), y la introducción de otros asociados a la agricultura, como plaguicidas [3-5].

Ante la relevancia del cambio composicional de los piensos de acuicultura en el ámbito socioeconómico y medioambiental [6], el desarrollo de métodos analíticos para la determinación de contaminantes orgánicos se ha convertido en una herramienta esencial para obtener datos fiables que contribuyan a mejorar el proceso de producción y a asegurar la calidad del producto final al consumidor. Así pues, este nuevo escenario en el campo de la acuicultura plantea un desafío analítico dado el elevado número de potenciales contaminantes, la diversidad de propiedades físico-químicas de los mismos, la complejidad y variedad de matrices a analizar y los bajos niveles de concentración a los que se pueden encontrar. Por ello, como se ha comentado 
en el capítulo 1, resulta imprescindible establecer estrategias analíticas basadas en el acoplamiento cromatografía-espectrometría de masas que permitan mejorar el alcance de los análisis.

Tradicionalmente, la determinación de contaminantes orgánicos se ha llevado a cabo mediante métodos pre-target basados en GC-MS/MS y LC-MS/MS [7-10]. Sin embargo, estos métodos únicamente permiten el análisis de un número preestablecido de compuestos, lo que supone un inconveniente a la hora de ampliar el alcance del análisis. Por ello, en el ámbito de la investigación de contaminantes orgánicos en el medio ambiente, ha crecido el interés por los métodos de screening basados en la espectrometría de masas de alta resolución (HRMS), dada la posibilidad de obtener rápidamente una respuesta cualitativa sobre la presencia o ausencia de un mayor número de compuestos de interés para su posterior confirmación y/o cuantificación. Estos últimos métodos deben ser rápidos, fácilmente actualizables, con un tratamiento de muestra lo más genérico posible y lo suficientemente sensibles para poder controlar el cumplimiento de los MRLs. Y, además, deben ser fiables, por lo que, al igual que los métodos pre-target cuantitativos, también han de someterse a un proceso de validación.

El proceso de validación de métodos de screening basados en HRMS pretende establecer el nivel de concentración mínimo (o límite de detección de screening, SDL), mediante el análisis de muestras fortificadas a diferentes niveles de concentración, para el cual el método detecta los compuestos de interés con un grado determinado de confianza. Sin embargo, los criterios de identificación que establecen dichos límites son objeto de debate entre la comunidad científica. Por una parte, la directiva 2002/657/CE de la Comisión Europea fundamenta la identificación en base a puntos de identificación (IPs), 
es decir, cuantifica el grado de confianza de la identificación teniendo en cuenta el número de iones diagnóstico que cumplen unas tolerancias establecidas para la relación q/Q, así como el tipo de analizador de masas utilizado [11]. Por otra parte, la guía SANTE/11813/2017 fundamenta la identificación en base a la presencia y la exactitud de masa del ion precursor y de, al menos, un ion fragmento [12]. Pese a que ambas guías tienen en cuenta la resolución de los analizadores utilizados, únicamente la segunda de ellas se centra en la exactitud de masa, valorando objetivamente la selectividad instrumental. Por este motivo, los criterios de identificación en métodos de screening seguidos en esta tesis han adoptado aquellos de la guía SANTE/11813/2017, si bien se ha adaptado la nomenclatura a la utilizada por Hernández et al [13] en función del uso o no de patrones de referencia para confirmar la identidad de compuestos mediante el tiempo de retención cromatográfico (ver figura 1).

Por definición, la identificación implica asegurar que la respuesta obtenida se corresponde inequívocamente a un analito concreto. En caso contrario, es habitual referirse a la detección o identificación tentativa de un compuesto, requiriendo un segundo análisis para su identificación. Sin embargo, la guía SANTE/11813/2017 también la define como el "resultado cualitativo de un método capaz de proporcionar información estructural que cumple con criterios aceptables para el propósito del análisis" [12]; y aclara en el apartado D8 que aunque "los diferentes tipos de analizadores de masas y modos de adquisición proporcionan diferentes grados de selectividad - lo que se relaciona con la confianza en la identificación - los requisitos para la identificación deben considerarse como criterios de orientación, no como criterios absolutos para demostrar la presencia o ausencia de un analito" [12]. Tal es así que esta guía únicamente requiere un porcentaje menor del 5\% de 
falsos negativos en la validación de métodos de screening pero no contempla un porcentaje mínimo de falsos positivos, recayendo la confirmación de los mismos en un método de identificación, es decir, en el reanálisis de la muestra mediante una metodología independiente a la utilizada [14]. Por esta razón, posterior al screening, es habitual y recomendable desarrollar, validar y aplicar métodos basados en analizador de QqQ, para la confirmación y cuantificación de los compuestos identificados reportados.

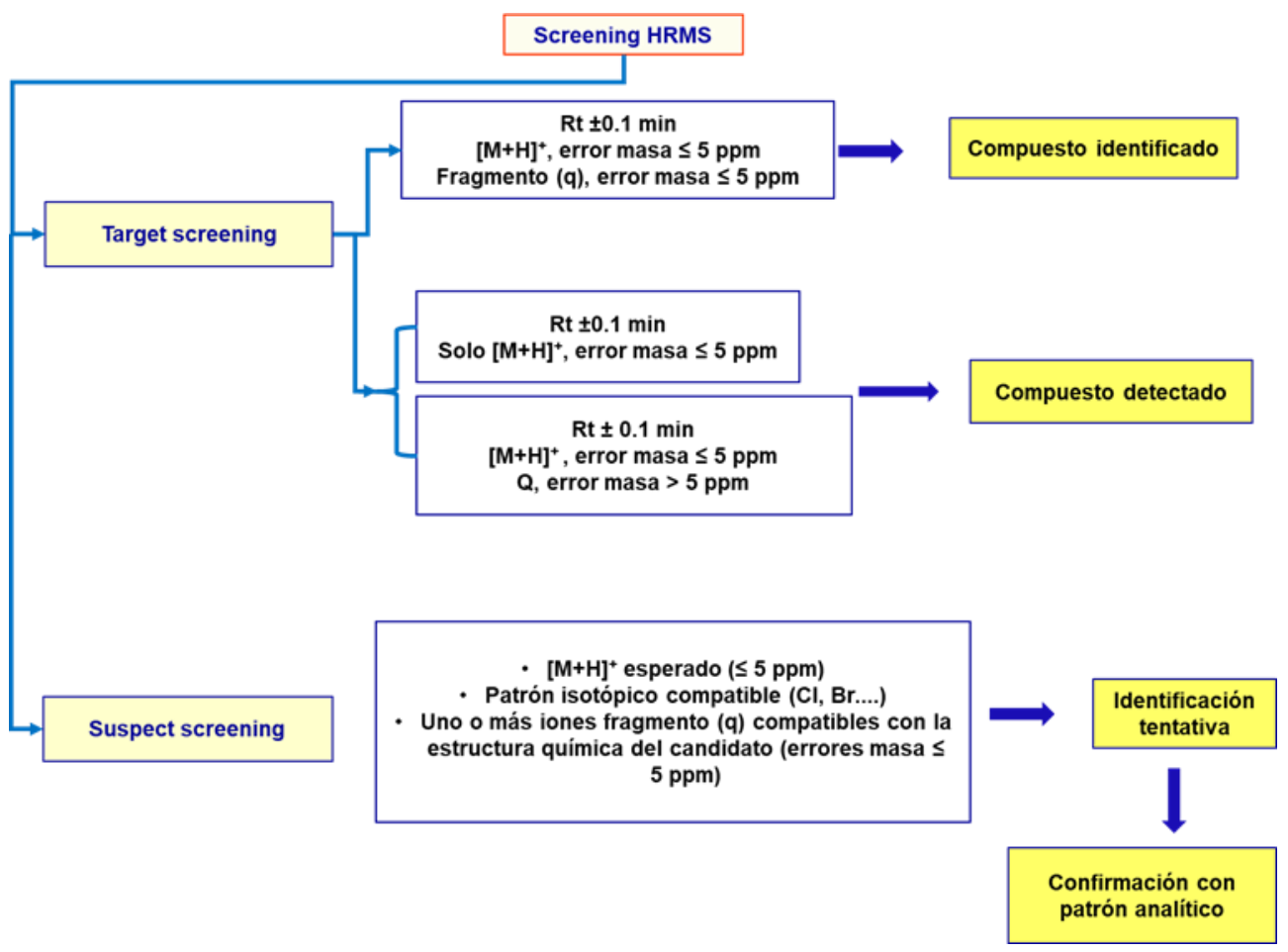

Figura 1: Esquema general del procesamiento de datos en métodos de screening. 
En el presente capítulo se discute el desarrollo, validación y aplicación de una estrategia analítica integral para la identificación, confirmación y cuantificación de PAHs y pesticidas en muestras de acuicultura. La estrategia propuesta en este capítulo se presenta como una herramienta de evaluación de riesgos disponible para la industria acuícola con el objetivo de ampliar el conocimiento sobre los nuevos ingredientes introducidos en los piensos, los mismos piensos y las partes comestibles de las especies cultivadas.

En primer lugar, y como objetivo principal de artículo científico I, se valida un método de screening de pesticidas para el análisis de más de veinte matrices de acuicultura diferentes mediante el uso combinado de los acoplamientos LCQTOF MS y GC-APCI-QTOF MS. Tras la validación, se aplica a las muestras siguiendo las aproximaciones target screening y suspect screening reportando la identificación de dieciséis pesticidas diferentes. Con el propósito de confirmar los compuestos reportados, cuantificarlos y ampliar el alcance del análisis con la determinación de PAHs i PCBs, en el artículo científico II se desarrolla, valida y aplica un método basado únicamente en GC-APCIMS/MS con analizador QqQ. Además, en este artículo se evalúa el potencial de la técnica GC-APCI-MS/MS para realizar la cuantificación de matrices complejas mediante el uso de calibrado en solvente.

Todos los trabajos realizados en este capítulo se han desarrollado en el marco del proyecto europeo ARRAINA (Advanced Research Initiatives for Nutrition and Aquaculture). 



\subsection{Artículo científico I}

Chemosphere 179 (2017) 242-253

Contents lists available at ScienceDirect

Chemosphere

journal homepage: www.elsevier.com/locate/chemosphere

Comprehensive strategy for pesticide residue analysis through the production cycle of gilthead sea bream and Atlantic salmon

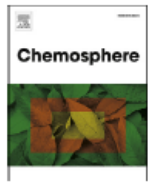

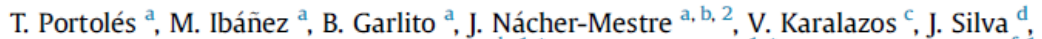

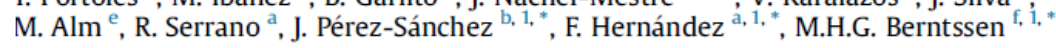

a Research Institute for Pesticides and Water (IUPA), Avda. Sos Baynat, s/n, University Jaume I, 12071 Castellón, Spain

b Institute of Aquaculture of Torre la Sal (IATS, CSIC), 12595 Ribera de Cabanes, Castellón, Spain

'BioMar R\&D, Grangemouth, FK3 8UL, UK

¿ BioMar AS, N-7010 Trondheim, Norway

'European Fat Processors and Renderers Assodiation (EFPRA), Boulevard Baudouin, 1518, 4th Fioor, BE - 1000, Brussels, Belgium

${ }^{f}$ National Institute of Nutrition and Seafood Research, PO Box 2029 Nordnes, N-5817 Bergen, Norway

H I G H L I G H T S

- Complementary use of GC and UHPLC coupled to single QTOF MS platform. - 800 pesticides were investigated in matrices from the marine food production chain.

- SDLs and LOQs at 0.01 and $0.005 \mathrm{mg} /$ $\mathrm{kg}$ achieved by GC\&LC-QTOF and GCAPCI-MS/MS.

- Plant material showed highest pesticide indices, with no feed-tot-fillet transfer.

- Processed animal proteins had low pesticide indices.

\section{A R T I C L E I N F O}

Article history:

Received 23 January 2017

Received in revised form

22 March 2017

Accepted 24 March 2017

Available online 27 March 2017

Handling Editor: David Volz

\section{Keywords:}

Fish

Processed animal products

Processed

Screening

Quadrupole time-of-flight
G R A P H I C A L A B S T R A C T

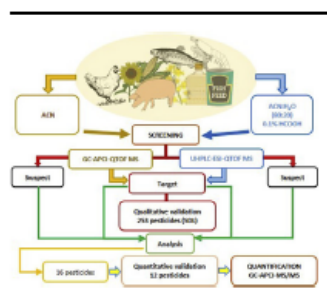

\section{A B S T R A C T}

Plant ingredients and processed animal proteins are altemative feedstuffs for fish feeds in aquaculture. However, their use can introduce contaminants like pesticides that are not previously associated with marine Atlantic salmon and gilthead sea bream farming. This study covers the screening of around 800 pesticides by gas chromatography (GC) and liquid chromatography (LC) coupled to high resolution timeof-flight mass spectrometry in matrices throughout the entire marine food production chain. Prior to analysis of real-world samples, the screening methodology was validated for 252 pesticides to establish the screening detection limit. This was $0.01 \mathrm{mg} \mathrm{kg}^{-1}$ for 113 pesticides (45\%), $0.05 \mathrm{mg} \mathrm{kg}^{-1}$ for 73 pesticides (29\%) and $>0.05 \mathrm{mg} \mathrm{kg}^{-1}$ for 66 pesticides (26\%). After that, a quantitative methodology based on GC coupled to tandem mass spectrometry with atmospheric pressure chemical ionization source (GCAPCI-MS/MS) was optimized for the pesticides found in the screening. Although several polar pesticides, of which pirimiohos methvl and chlorovriphos-methvl were most dominant. were found in plant material and feeds based on these ingredients, none of them were observed in fillets of Atlantic salmon and gilthead sea bream fed on these feeds.

\footnotetext{
- Corresponding authors

E-mail addresses: jaime.perez.sanchez@csices (J. Pérez-Sánchez), felix.

hernandez@uji.es (F. Hernández), Marc.Berntssen@nifes,no (M.H.G. Berntssen).

1 Equally shared senior authorship.

2 Current address: Nutrigenomics and Fish Growth Endocrinology Group, Insti-

tute of Aquaculture Torre la Sal, IATS-CSIC, Ribera de Cabanes, Castellón, Spain. 
Chemosphere 179 (2017) 242-253

\section{Comprehensive strategy for pesticide residue analysis through the production cycle of gilthead sea bream and Atlantic salmon}

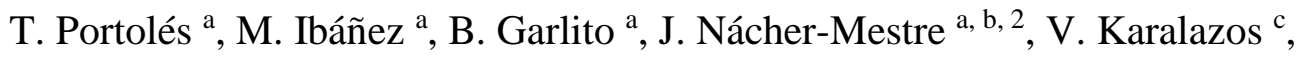

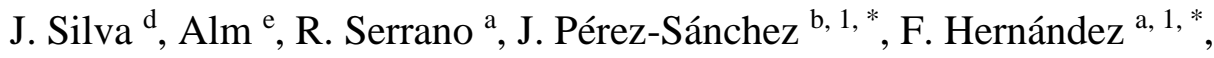
M.H.G. Berntssen ${ }^{\mathrm{f}, 1, *}$

${ }^{a}$ Research Institute for Pesticides and Water (IUPA), Avda. Sos Baynat, s/n, University Jaume I, 12071 Castellón, Spain

${ }^{\mathrm{b}}$ Institute of Aquaculture of Torre la Sal (IATS, CSIC), 12595 Ribera de Cabanes, Castellón, Spain

${ }^{\mathrm{c}}$ BioMar R\&D, Grangemouth, FK3 8UL, UK

${ }^{d}$ BioMar AS, N-7010 Trondheim, Norway

${ }^{\mathrm{e}}$ European Fat Processors and Renderers Association (EFPRA), Boulevard Baudouin, 1518, 4th Floor, BE - 1000, Brussels, Belgium

${ }^{\mathrm{f}}$ National Institute of Nutrition and Seafood Research, PO Box 2029 Nordnes, N-5817 Bergen, Norway

\section{Abstract}

Plant ingredients and processed animal proteins are alternative feedstuffs for fish feeds in aquaculture. However, their use can introduce contaminants like pesticides that are not previously associated with marine Atlantic salmon and gilthead sea bream farming. This study covers the screening of around 800 pesticides by gas chromatography (GC) and liquid chromatography (LC) coupled to high resolution time-of-flight mass spectrometry in matrices throughout the entire marine food production chain. Prior to analysis of real- 
world samples, the screening methodology was validated for 252 pesticides to establish the screening detection limit. This was $0.01 \mathrm{mg} \cdot \mathrm{kg}^{-1}$ for 113 pesticides (45\%), $0.05 \mathrm{mg} \cdot \mathrm{kg}^{-1}$ for 73 pesticides (29\%) and $>0.05 \mathrm{mg} \cdot \mathrm{kg}^{-1}$ for 66 pesticides (26\%). After that, a quantitative methodology based on GC coupled to tandem mass spectrometry with atmospheric pressure chemical ionization source (GC-APCI-MS/MS) was optimized for the pesticides found in the screening. Although several polar pesticides, of which pirimiphos methyl and chlorpyriphos-methyl were most dominant, were found in plant material and feeds based on these ingredients, none of them were observed in fillets of Atlantic salmon and gilthead sea bream fed on these feeds.

\section{Highlights}

- Complementary use of GC and UHPLC coupled to single QTOF MS platform. 800 pesticides were investigated in matrices from the marine food production chain. SDLs and LOQs at 0.01 and $0.005 \mathrm{mg} \cdot \mathrm{kg}^{-1}$ achieved by GC\&LC-QTOF and GC-APCI-MS/MS. Plant material showed highest pesticide indices, with no feed-to-fillet transfer. Processed animal proteins had low pesticide indices.

\section{Keywords}

Fish, feed, processed animal products, screening, pesticides, quadrupole timeof-flight. 


\section{Graphical abstract}

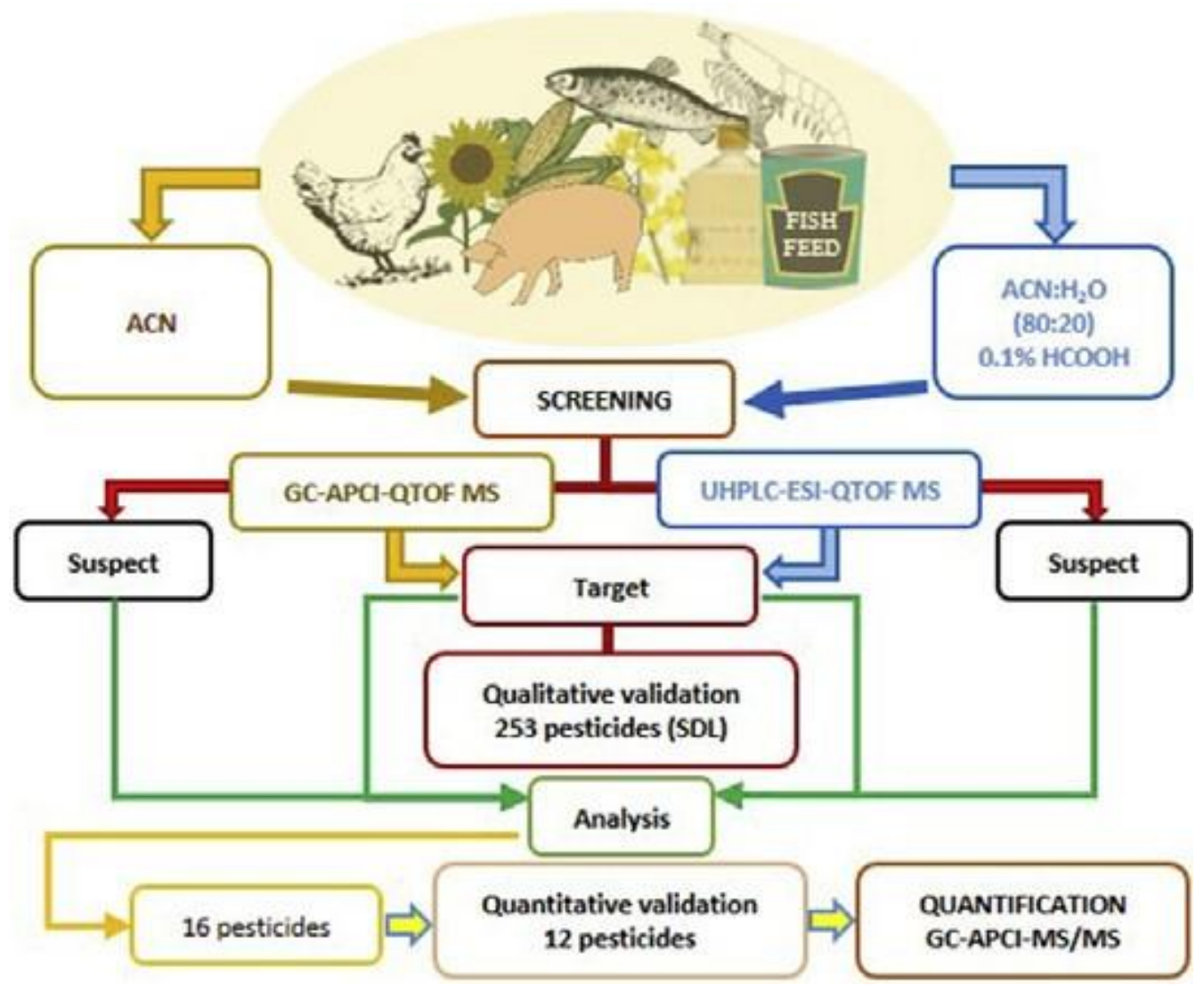




\section{Introduction}

The availability of wild fishery-derived raw materials is finite and the rapid and sustained growth rate of global aquaculture have forced the industry to explore alternative and more sustainable feed ingredients (Tacon and Metian, 2013). Much attention has been paid to plant ingredients and experimental evidence supports a successful replacement of marine feedstuffs at relatively high levels in most carnivorous farmed fish, such as Atlantic salmon (Salmo salar) and gilthead seabream (Sparus aurata) (Benedito-Palos et al., 2016; Ytrestøyl et al., 2015). Processed animal proteins (PAPs) from the rendering industry, re-authorized for use in aquafeeds in the European Union (EU) in 2013 (EC, 2013a), are another valuable source of feed ingredients for farmed marine fish (Hatlen et al., 2015).

The use of these alternative feed ingredients can introduce contaminants that were previously not associated with marine salmon and gilthead sea bream farming. One example are pesticides that are world-wide pre and post-harvest used on crops or as anti-parasite agent in farming of terrestrial animals. Well known organochlorine pesticides (OCP) such as DDT and HCB have been mostly banned for agricultural use and are associated with fish oil (Berntssen et al., 2010; Friesen et al., 2008; Nácher-Mestre et al., 2009). These OCP pesticides have been replaced by less persistent and more water soluble pesticides (Seiber, 2002). EU Maximum Residue Level (MRL) legislation for non-OCP pesticides comprises most food commodities (EC, 2005), but for feed ingredients and fish, specific harmonized EU MRLs are not yet established (EC, 2013b). This emphasizes the need for data on the occurrence of pesticides in feed ingredients and the edible part of fish farmed on plantbased feeds. Extensive EU surveillance programmes exist on pesticide 
residues in food (EFSA, 2013). Several surveillance studies report on pesticides in terrestrial animals feed (i.e (Gómez-Pérez et al., 2015)) as well as potential transfer of the pesticides to edible part of animals such as meat milk and eggs (Kan and Meijer, 2007; Leeman et al., 2007). For farmed fish, occurrence and feed-to-fillet transfer data on most (non POPs) pesticides, is limited (Lovell et al., 1996; Nácher-Mestre et al., 2014).

In addition to the above findings, the different physicochemical characteristics of pesticides, together with the low concentration levels established by current legislation and the complexity of the matrices make necessary the use of last generation analytical techniques. Multi-residue methods (MRM) are applied with a clear tendency to liquid chromatography-mass spectrometry (LC-MS), although gas chromatography-MS (GC-MS) is still required to widen the number of compounds investigated. Thus, the combined use of GC and LC with tandem MS with last generation triple quadrupole (QqQ) instruments is one of the best options to get the sensitivity and selectivity required (Golge and Kabak, 2015; Hernández et al., 2012, 2013). Additionally, accurate-mass full-spectrum data obtained by high resolution MS opens the possibility to provide a complete overview of pesticide pollution, and not only those compounds initially targeted can be investigated. LC coupled to quadrupoletime of flight (QTOF) MS with electrospray (ESI) source has been widely explored for the screening of polar contaminants, their metabolites and transformation products (TPs) (Hernández et al., 2014, 2015a; Nácher-Mestre et al., 2013). In relation to GC-MS, the soft ionization obtained from atmospheric pressure chemical ionization (APCI) source in GC-MS instruments has offered attractive features for screening purposes (Portolés et al., 2010, 2014). All this, thereby, opens fascinating perspectives in the analytical field (Hernández et al., 2015b; Pitarch et al., 2016) towards the 
screening of thousands of contaminants without standards (Castillo et al., 2016; Hernández et al., 2015b; Krauss et al., 2010).

The present work is based on our previous research on screening of pesticide residues (Nácher-Mestre et al., 2013, 2014) in farmed fish. A comprehensive strategy is presented for screening, identification and quantification of around 800 pesticides in commercially available plant and novel PAP feed ingredients and their transfer to the edible part of farmed Atlantic salmon and gilthead sea bream (two main species of the European aquaculture). The screening considers an initial qualitative validation of 252 pesticides using GC(APCI)QTOF MS and UHPLC-(ESI)QTOF MS, followed by a target quantitative assessment by GC-(APCI)MS/MS QqQ for those pesticides identified in the qualitative validation.

\section{Materials and methods}

\subsection{Chemicals and reagents}

All pesticides and isotopically labelled reference standards were purchased from Dr. Ehrenstorfer (Augsburg, Germany) and Sigma Aldrich (St Louis, MO, USA). Isotopically labelled internal standards (ILIS) Hexachlorobenzene- ${ }^{13} \mathrm{C}_{6}$, Tebuconazole- $\mathrm{D}_{6}$ and $4,4^{\prime}-\mathrm{DDE}-\mathrm{D}_{8}$ were also purchased from Dr. Ehrenstorfer. All standards had purities higher than 95\%. Stock standard solutions (around $500 \mathrm{mg} \cdot \mathrm{L}^{-1}$ ) were prepared in acetone and were stored at $-20^{\circ} \mathrm{C}$. Twenty-two mixtures of pesticide standards (individual concentration of each pesticide around $50 \mathrm{mg} \cdot \mathrm{L}^{-1}$ ) were prepared by dilution of stock individual solutions in acetone. Working standard solutions 
containing all pesticides were prepared by dilution of mixtures with acetone (for sample fortification in GC), hexane (GC injection), methanol (for sample fortification in LC) and water (instrument injection in LC). Stock standard solutions were stored at $-20^{\circ} \mathrm{C}$, whereas working solutions were stored at $4^{\circ} \mathrm{C}$.

HPLC-grade water was obtained from a MilliQ water purification system (Millipore Ltd., Bedford, MA, USA). HPLC-grade methanol, HPLCsupragradient acetonitrile, acetone (pesticide residue analysis quality) and nhexane (all ultra-trace quality) were purchased from Scharlab (Barcelona, Spain). Formic acid $(\mathrm{HCOOH}$, content $>98 \%)$, sodium hydroxide $(\mathrm{NaOH}$, reagent grade) and ammonium acetate $\left(\mathrm{NH}_{4} \mathrm{Ac}\right.$, reagent grade) were supplied by Scharlab. Anhydrous magnesium sulfate (extra pure) and anhydrous sodium acetate (reagent grade) were purchased from Scharlab. Leucine enkephalin (used as lock mass in LC) and heptacosa (for GC calibration) were purchased from Sigma Aldrich.

QuEChERS commercial clean-up kits were purchased from Teknokroma (Barcelona, Spain). Each kit contains $50 \mathrm{mg}$ of primary-secondary amine (PSA), $150 \mathrm{mg}$ of anhydrous magnesium sulfate, and $50 \mathrm{mg}$ of $\mathrm{C}_{18}$, in $2 \mathrm{~mL}$ microcentrifuge tubes for d-SPE.

\subsection{Samples}

A total of 76 samples were studied in this work as detailed in Table S1. The list contains ingredients from different origin (plant, terrestrial animals and marine), and also feeds based on these feed ingredients, as well as fillets of Atlantic salmon and gilthead seabream reared on these feeds. Atlantic salmon 
and gilthead seabream were fed by the produced feeds for 7 and 18 months, respectively, and fillet samples were taken for analysis at the end of the exposure trial. The same feeds were provided throughout the feeding trial. The screening and quantification was performed on feed ingredients, feeds produced from the same feed ingredients, and fish fillets of fish fed on these feeds. The feed samples were analyzed at the beginning of the trial and no stability assessment was made by analyzing the feed during storage.

Commercially available plant and marine feed ingredients were provided by BioMar (Tech Center, Brande, Denmark) feed producer and PAPs from nonruminants were provided by the European Fat Processors and Renderers Association (EFPRA). All PAPs were produced according the EU regulation for PAP intended for use as feed-ingredients in animal feed (EC, 2001, EC, 2009). The ingredients selected represent the novelties in fish feed compositions to reduce the inclusion of fish derivatives. Fish feeds for feeding trials were based on plant feed ingredients, and not PAPs, as higher levels of pesticide residues were found in plant feed ingredients (see Section 3). The feeds were produced by BioMar under commercial aquafeed production techniques based on high-temperature extrusion processes, which potentially could affect pesticide residue levels. 


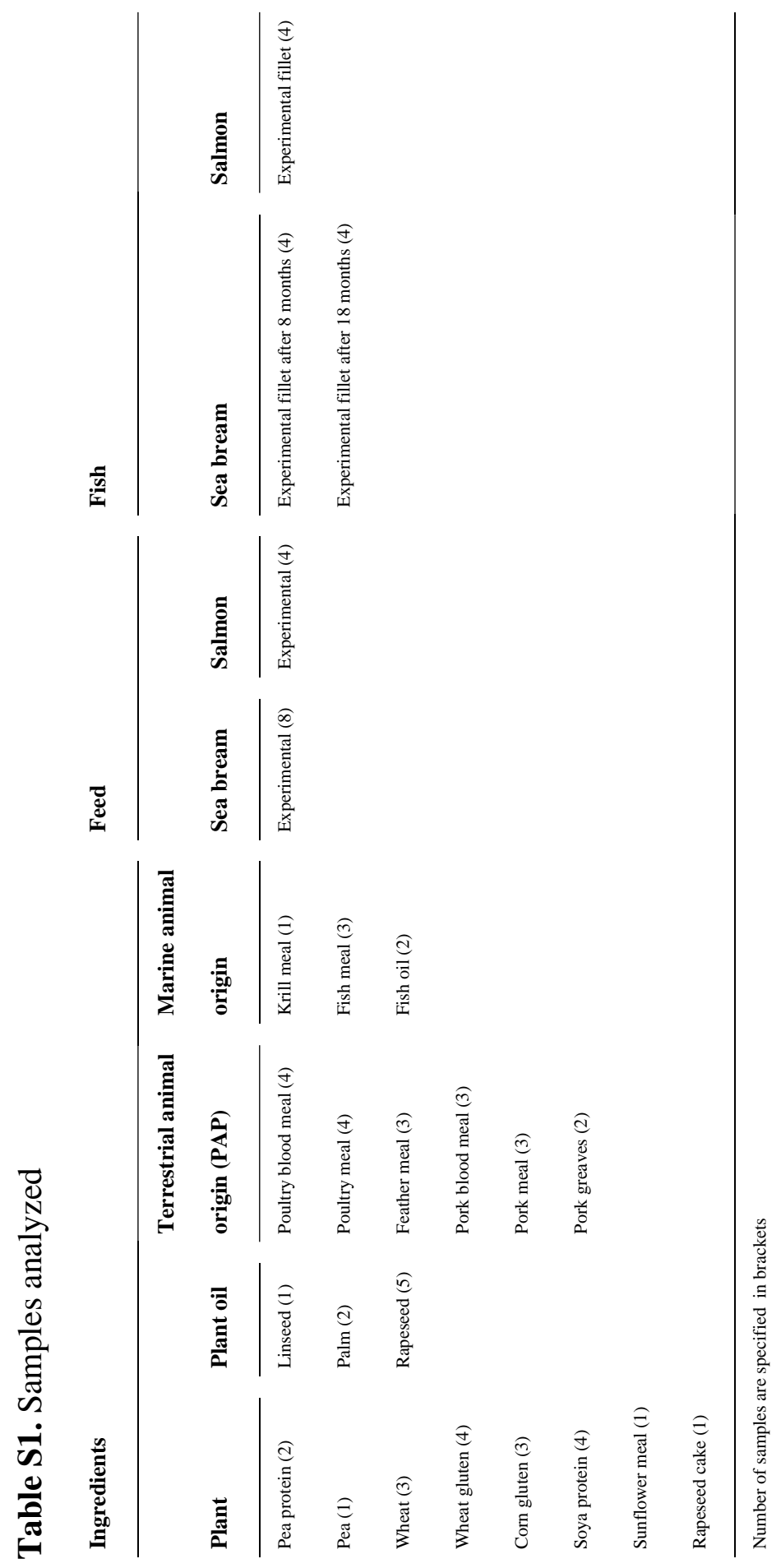




\subsection{Wide scope screening work-flow}

The sample procedure applied for pesticides screening and quantification is illustrated in Fig. 1. Briefly, samples were thawed at room temperature and 5 $\mathrm{g}$ were accurately weighed and transferred to centrifuge tubes $(50 \mathrm{~mL})$. For GC-analysis, samples were extracted with acetonitrile $(10 \mathrm{~mL})$ and the extract was subsequently left in a freezer (at least for $2 \mathrm{~h}$ to precipitate proteins and fix lipids to the tube walls). Then, a QuEChERS clean-up step was carried out prior injection in the GC-system (Nácher-Mestre et al., 2014). In the LCscreening, similar procedure was followed without any purification or preconcentration step (Fig. 1). In this case, extraction of the samples was carried out with acetonitrile/water 80:20 (0.1\% formic acid (Nácher-Mestre et al., 2013).

Pesticides found by the GC\&LC-QTOF MS screening were subsequently confirmed and quantified by GC-(APCI)MS/MS QqQ. Sample treatment was similar to that applied for GC-screening with two slight variations: i) $1 \mathrm{~g}$ (instead of $5 \mathrm{~g}$ ) of sample was spiked with isotopically labelled internal standards and extracted with $2 \mathrm{~mL}$ of acetonitrile (instead of $10 \mathrm{~mL}$ ); ii) just before injection, $50 \mu \mathrm{L}$ of the final acetonitrile extract was diluted with 300 $\mu \mathrm{L}$ of acetone and $650 \mu \mathrm{L}$ of hexane in order to make the solution miscible. 


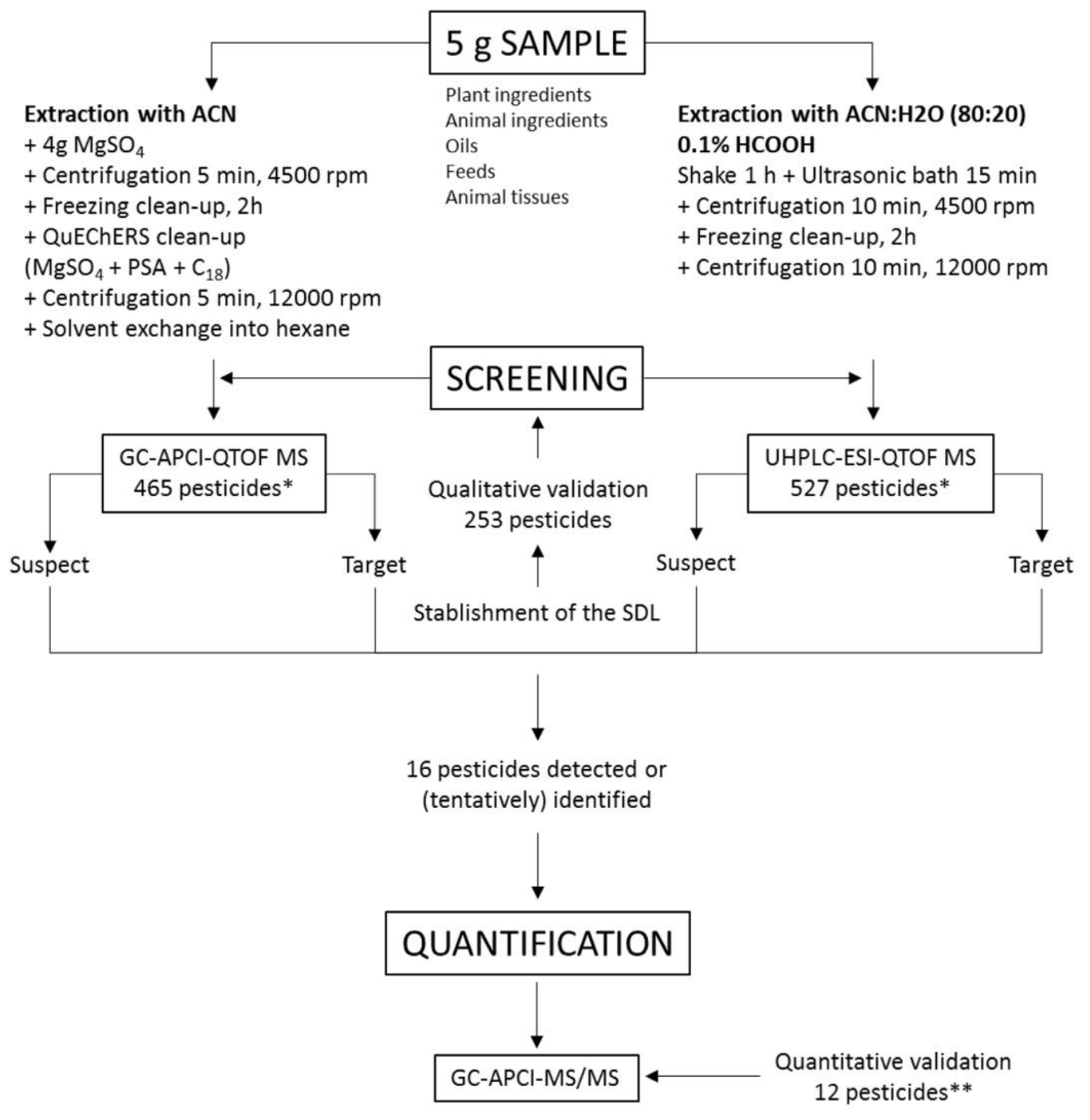

\footnotetext{
* Around 200 compounds were included in both databases; therefore, the total number of pesticides searched in the comprehensive screening was near 800 .

** 4 out of 16 pesticides were not GC-amenable and should be determined by LC-MS/MS
}

Fig. 1. Scheme of the sample procedure for screening and quantification of pesticides in aquaculture field. 


\subsection{Screening validation}

For qualitative analysis of GC-amenable compounds, an Agilent 7890A GC system (Palo Alto, CA, USA) equipped with an Agilent 7693 autosampler was coupled to the Xevo G2 QTOF (Waters, Manchester, UK), operating in APCI mode. For qualitative analysis of LC-amenable compounds, a Waters Acquity UHPLC system (Waters, Milford, MA, USA) was coupled to a XEVO G2 QTOF (Waters, Manchester, UK), with an orthogonal Z-spray-ESI interface operating in both positive and negative ionization modes.

\section{$\underline{\text { GC-(APCI)QTOF MS }}$}

The GC separation was performed using a fused silica DB-5MS capillary column with a length of $30 \mathrm{~m} \times 0.25 \mathrm{~mm}$ i.d. and a film thickness of $0.25 \mu \mathrm{m}$ (J\&W Scientific, Folson, CA, USA). The oven temperature was programmed as follows: $90^{\circ} \mathrm{C}(1 \mathrm{~min}) ; 5^{\circ} \mathrm{C} / \mathrm{min}$ to $315^{\circ} \mathrm{C}(2 \mathrm{~min})$. Pulsed splitless (50 psi) injections of $1 \mu \mathrm{L}$ of sample extracts were carried out with an injector temperature of $280^{\circ} \mathrm{C}$ and with a splitless time of 1 min. Helium $99.999 \%$ (Praxair, Valencia, Spain) was used as carrier gas at a constant flow of 2 $\mathrm{mL} / \mathrm{min}$. The interface and source temperatures were set to $310{ }^{\circ} \mathrm{C}$ and 150 ${ }^{\circ} \mathrm{C}$, respectively. The make-up gas $\left(\mathrm{N}_{2}\right)$ was set at $320 \mathrm{~mL} / \mathrm{min}$ flow, the auxiliary gas at $150 \mathrm{~L} / \mathrm{h}$ and the cone gas at $16 \mathrm{~L} / \mathrm{h}$. The voltage of the sampling cone was set at $20 \mathrm{~V}$, the voltage of the extraction cone was $4 \mathrm{~V}$, and the APCI corona pin was fixed at a current $1.7 \mu \mathrm{A}$. The ionization process occurred within an enclosed ion volume, which enabled control over the protonation/charge transfer processes. A scan time of $0.4 \mathrm{~s}$ was selected and MS data were acquired over an $\mathrm{m} / \mathrm{z}$ range of 50-650.

For $\mathrm{MS}^{\mathrm{E}}$ experiments, two acquisition functions with different collision 
energies were created and applied simultaneously in each sample injection: the low energy function (LE), selecting a collision energy of $4 \mathrm{eV}$, and the second one, the high energy function (HE), with a collision energy ramp ranging from 10 to $40 \mathrm{eV}$. TOF MS resolution was approximately 20,000 (FWHM) at $m / z 614$.

Two injections were performed for sample: the first one promoting the formation of the molecular ion, and the second one, promoting the formation of the protonated molecule. Full-spectrum acquisition data generated at low and high collision energy $\left(\mathrm{MS}^{\mathrm{E}}\right)$ were processed, using the specialized application manager ChromaLynxXS (within MassLynx).

Heptacosa was used for the daily mass calibration. Continuous internal calibration was performed using a background ion coming from the GCcolumn bleeding as lock mass $(\mathrm{m} / \mathrm{z}$ 223.0640).

\section{$\underline{\text { UHPLC-(ESI)QTOF MS }}$}

An Acquity UHPLC BEH C18 $1.7 \mu$ m particle size analytical column 100×2.1 $\mathrm{mm}$ (Waters) at a flow rate of $300 \mu \mathrm{L} / \mathrm{min}$ was employed for chromatographic separation. Mobile phase consisted of water/methanol gradient both with $0.01 \% \mathrm{HCOOH}$. The percentage of organic modifier (B) was changed linearly as follows: $0 \mathrm{~min}, 10 \%$; $14 \mathrm{~min}, 90 \%$; $16 \mathrm{~min}, 90 \%$; $16.01 \mathrm{~min}, 10 \%$; 18 $\min , 10 \%$. The column temperature was set at $40{ }^{\circ} \mathrm{C}$. Hybrid TOF MS resolution was approximately 20,000 at full width half maximum (FWHM), at $\mathrm{m} / \mathrm{z}$ 556.2771. MS data were acquired on the $\mathrm{m} / \mathrm{z}$ range of 50-1000. A capillary voltage of $0.7 \mathrm{kV}$ in positive mode and $2.5 \mathrm{kV}$ in negative mode were used with a cone voltage of $25 \mathrm{~V}$. Collision gas was argon 99.995\% (Praxair, Valencia, Spain). The interface temperature was set to $650{ }^{\circ} \mathrm{C}$ and the source 
temperature at $130{ }^{\circ} \mathrm{C}$.

Similarly to GC-QTOF MS, for $\mathrm{MS}^{\mathrm{E}}$ experiments two acquisition functions were created: the low energy function (LE), selecting a collision energy of 4 $\mathrm{eV}$, and the second one, the high energy function (HE), with a collision energy ramp ranging from 15 to $40 \mathrm{eV}$.

MS data were acquired in centroid mode and were processed by the ChromaLynx XS application manager (within MassLynx v 4.1; Waters Corporation).

Calibrations were conducted daily from $\mathrm{m} / \mathrm{z}, 50$ to 1000 with a 1:1 mixture of $0.05 \mathrm{M} \mathrm{NaOH}: 5 \% \mathrm{HCOOH}$ diluted (1:25) with acetonitrile: water (80:20), at a flow rate of $20 \mu \mathrm{L} / \mathrm{min}$. For automated accurate mass measurement, the lockspray probe was used, using as lock mass a solution of leucine enkephalin (10 $\mathrm{mg} / \mathrm{L})$ in acetonitrile:water (50:50) at $0.1 \% \mathrm{HCOOH}$ pumped at $30 \mu \mathrm{L} / \mathrm{min}$ through the lock-spray needle. The (de)protonated molecule of leucine enkephalin at $\mathrm{m} / \mathrm{z} 556.2771$ in positive mode and $\mathrm{m} / \mathrm{z} 554.2615$ in negative mode was used for recalibrating the mass axis and ensuring a robust accurate mass measurement along time.

Validation of the two screening methods applied (GC-QTOF MS for 170 pesticides and UHPLC-QTOF MS for 162 pesticides) was performed for qualitative purposes on the basis of European analytical guidelines (Sanco, 2013). To this aim, at least twenty sample matrices (including different feed ingredients, feed and fish) were spiked with pesticides at two concentrations, 0.01 and $0.05 \mathrm{mg} \cdot \mathrm{kg}^{-1}$ and, analyzed together with their respective non-spiked samples ("blanks") and method blanks to assure absence of contamination along the procedure. The main parameter evaluated was screening detection 
limit (SDL), which was the lowest concentration for which each pesticide was detected in $95 \%$ of the spiked samples tested (e.g. 19 out of 20 samples) independently of its recovery and precision. The detection of the compound was made by using the most abundant ion measured at its accurate mass (typically the molecular ion or (de)protonated molecule) in the LE function. This implied that at least one $\mathrm{m} / \mathrm{z}$ ion was observed at the expected retention time (Rt) (deviation accepted $\pm 0.2 \mathrm{~min}$, in comparison with the reference standard) with mass error below $5 \mathrm{ppm}$.

The GC-QTOF MS qualitative screening had been previously validated for 131 pesticides in twenty aquaculture samples in a previous work (NácherMestre et al., 2014). In this work, validation was widened with 39 pesticides in relation to our previous work and was tested for new sample matrices from the fish growing trials. To this aim, 4 additional matrices (gilthead sea bream fillet, salmon fillet and two additional fish feed) were spiked with the already validated 131 pesticides together with the new 39 pesticides. For those 4 new matrices, a criteria of 4 positives out of 4 analyzed was required to accept the SDL. This allowed us to check and confirm the SDLs previously established for the 131 pesticides, as well as establishing provisional SDLs for the additional 39 pesticides studied. Furthermore, 6 PAP matrices were also subjected to the same methodology, and spiked at the concentration levels indicated above. With a requirement of 6 positives out of the 6 samples analyzed, provisional SDLs were also established.

Regarding LC-QTOF MS screening, the validation has been performed in two steps as a function of the availability of the samples. Similarly to GC-QTOF MS, in a first step, the LC screening was qualitatively validated in twenty different sample matrices (feed ingredients, feed and fish) spiked with 125 
pesticides at two concentrations, 0.01 and $0.05 \mathrm{mg} \cdot \mathrm{kg}^{-1}$, and the SDL was established. The detection was made by using the (de)protonated molecule, so at least one $\mathrm{m} / \mathrm{z}$ ion was found at the expected Rt (deviation accepted \pm 0.2 min) with mass error below 5 ppm. The LC qualitative screening was widened, in a second step, with 36 pesticides. Also, 4 additional samples (the same as in GC-QTOF MS) were spiked with the already validated 125 compounds and 36 more pesticides. This allowed us to confirm the SDLs already established in the first step and also establish provisional SDLs for the 36 new pesticides. Additionally, 6 PAPs were also spiked at the concentration levels cited above and for those samples a criteria of 6 out of 6 was required to establish a provisional SDL.

\subsection{Qualitative screening of aquaculture samples}

The overall strategy proposed was applied to the screening of aquaculture samples from a multidisciplinary European funded project (EU Seventh Framework Programme ARRAINA Project 288925). Samples analyzed covered the whole production chain of Atlantic salmon and gilthead sea bream. For these purposes, plant and marine ingredients as raw materials for aquafeed compositions from feed producers were all studied (Table S1). Fish tissues from gilthead sea bream and salmon feeding trials were analyzed in parallel. After injection of the sample extracts, full-spectrum acquisition data generated at low and high collision energy $\left(\mathrm{MS}^{\mathrm{E}}\right)$ were processed, using the specialized application manager ChromaLynxXS (within MassLynx) in combination with a home-made database containing 465 pesticides for GC and 527 for LC. Around 200 compounds were included in both databases; 
therefore, the total number of pesticides searched in the comprehensive screening was near 800 . The screening was applied for those compounds that were qualitatively validated (thus, reference standards were available) and also for those other pesticides included in the database, for which reference standards were not available (suspect screening). The detection of a potential positive was based on the presence of the (de)protonated molecule/molecular ion (occasionally adducts), measured at its accurate mass, in the LE function (for both GC and LC-QTOF). For this purpose, nw-XICs at the $m / z$ of all compounds included in the database were automatically performed in the LE function (150 ppm mass window) (Hernández et al., 2015b). Data from HE function was used to confirm the identity based to the presence of fragment ions.

When a sample was analyzed, the presence of chromatographic peak at the expected Rt, together with the evaluation of the accurate-mass fragment ions and characteristic isotopic ions, allowed the unequivocal confirmation of the identity of the compound detected when the reference standard was available. In the case of suspect analysis, the tentative identification was supported by MS/MS product ions reported in the literature for the suspect compound (either in exact or nominal mass) and by the compatibility of the fragment ion with the chemical structure of the candidate. Tentative identification was finally confirmed by subsequent acquisition of the reference standard, which was made at a later step. MassFragment software (Waters) was used to propose compatible structures from accurate mass measurements of the observed fragment ions.

All compounds detected (only one ion with accurate mass and Rt agreement) and/or identified (minimum two accurate-mass ions, with Rt and ion ratio 
agreement) were included in the GC-(APCI)MS/MS quantitative method developed. Those compounds from the suspect list that were just tentatively identified were also included in the target quantitative method.

\subsection{Quantitative analyses of aquacultural samples}

Quantitative analysis of selected pesticides was performed in a GC system (Agilent 7890B, Palo Alto, CA, USA) equipped with an autosampler (Agilent 7693) and coupled to QqQ mass spectrometer (Xevo TQ-S, Waters Corporation, Manchester, UK), operating in APCI mode.

\section{$\underline{\text { GC-(APCI)MS/MS }}$}

The GC separation was performed using a fused silica DB-17MS (50\% phenyl-methylpolysiloxane) capillary column with a length of $30 \mathrm{~m} \times 0.25$ $\mathrm{mm}$ i.d. and a film thickness of $0.25 \mu \mathrm{m}$ with a $1 \mathrm{~m}$ x $0.25 \mathrm{~mm}$ i.d deactivated post-column (J\&W Scientific, Folson, CA, USA). The oven temperature was programmed as follows: $70^{\circ} \mathrm{C}(1 \mathrm{~min}) ; 20^{\circ} \mathrm{C} / \mathrm{min}$ to $230{ }^{\circ} \mathrm{C} ; 5^{\circ} \mathrm{C} / \mathrm{min}$ to 320 ${ }^{\circ} \mathrm{C}$ (6 min). The injector was operated in pulsed splitless mode (50 psi), injecting $1 \mu \mathrm{L}$ at $280{ }^{\circ} \mathrm{C}$. Helium was used as carrier gas at a ramped flow mode programmed as follows: $2 \mathrm{~mL} \cdot \mathrm{min}^{-1}(23 \mathrm{~min})$; a ramp of $4 \mathrm{~mL} \cdot \mathrm{min}^{-1}$ to $6 \mathrm{~mL} \cdot \mathrm{min}^{-1}$ (9 $\left.\mathrm{min}\right)$. In the SRM method, automatic dwell time (values ranging from 3 to $63 \mathrm{~ms}$ ) was applied in order to obtain 15 points per peak. The interface and source temperatures were set to $320{ }^{\circ} \mathrm{C}$ and $150{ }^{\circ} \mathrm{C}$ respectively using $\mathrm{N}_{2}$ as auxiliary gas at $275 \mathrm{~L} \cdot \mathrm{h}^{-1}$, as make-up gas at 300 $\mathrm{mL} \cdot \mathrm{min}^{-1}$ and as cone gas at $200 \mathrm{~L} \cdot \mathrm{h}^{-1}$. The APCI corona discharge pin was operated at $1.6 \mu \mathrm{A}$. 
The ionization process occurred within an enclosed ion volume, which enabled control over the protonation/charge transfer processes. In order to work under proton transfer conditions, an uncapped vial containing water was placed in a designed holder into the APCI source door to enhance protonation.

Targetlynx (a module of MassLynx) was used to process the data acquired.

A quantitative method was optimized for those pesticides found in the screening of samples. Validation of the GC-(APCI)MS/MS method was performed for 12 out of 16 pesticides detected and/or identified in the samples. The remaining four compounds -flufenoxuron, tebufenozide, teflubenzuron and carbofuran-3OH- were not included in the quantification step as they are not GC-amenable compounds. Accuracy (estimated by means of recovery experiments) was evaluated by analyzing quality control (QC) samples spiked at 0.005 and $0.05 \mathrm{mg} \cdot \mathrm{kg}^{-1}$ in 26 "blank" samples (corresponding to 19 different matrices). The limit of quantification (LOQ) was established as the lowest concentration for which the method showed satisfactory recovery (between 60 and 140\%). Isotopically labelled internal standards were used to correct matrix effects and potential errors associated to sample manipulation (Portolés et al., 2017). 


\section{Results and discussion}

\subsection{Target and suspect screening of feed ingredients, feed and transfer to farmed fish}

Regarding GC-QTOF screening validation, among the 131 pesticides already studied, 121 maintained the already established SDL: $0.01 \mathrm{mg} \cdot \mathrm{kg}^{-1}$ (69 pesticides), $0.05 \mathrm{mg} \cdot \mathrm{kg}^{-1}$ (34 pesticides) and $>0.05 \mathrm{mg} \cdot \mathrm{kg}^{-1}$ (18 pesticides), and 4 improved/lowered this value (carbophenothion, chlorfenson, pendimethalin and tau-fluvalinate) (see Table S2). Only six pesticides did not pass the new criteria of 4 out of 4 in the new samples and sacrificed the SDL from 0.01 to $>0.05 \mathrm{mg} \cdot \mathrm{kg}^{-1}$ (diphenylamine and leptophos), or from 0.05 to $>0.05 \mathrm{mg} \cdot \mathrm{kg}^{-1}$ (chlorothalonil, heptachlor epoxide A, heptachlor epoxide B and propoxur). For the 39 additional pesticides studied in four new samples (including two fish feed and two fish fillets), a provisional SDL was established as $0.01 \mathrm{mg} \cdot \mathrm{kg}^{-1}$ for 13 pesticides, $0.05 \mathrm{mg} \cdot \mathrm{kg}^{-1}$ for 17 pesticides and $>0.05 \mathrm{mg} \cdot \mathrm{kg}^{-1}$ for 9 pesticides based on the 4 out of 4 criteria. SDLs obtained for PAPs coincided with those of feed ingredients, feed and fish for the great majority of analytes (82\% of cases, corresponding to 141 compounds).

Regarding LC-QTOF screening validation, for the first 125 pesticides studied, SDLs were established as $0.01 \mathrm{mg} \cdot \mathrm{kg}^{-1}$ (49 pesticides), $0.05 \mathrm{mg} \cdot \mathrm{kg}^{-1}$ (31 pesticides) and $>0.05 \mathrm{mg} \cdot \mathrm{kg}^{-1}$ (25 pesticides) and $18 \mathrm{improved} /$ lowered this value (see Table S3). Only two pesticides (chlorpropham and parathion-ethyl) did not pass the new criteria of 4 out of 4 in the new samples and sacrificed the SDL from 0.05 to $>0.05 \mathrm{mg} \cdot \mathrm{kg}^{-1}$. For the new 36 pesticides studied in four matrices, a tentative/provisional SDL was established as $0.01 \mathrm{mg} \cdot \mathrm{kg}^{-1}$ for 6 
pesticides, $0.05 \mathrm{mg} \cdot \mathrm{kg}^{-1}$ for 24 pesticides and $>0.05 \mathrm{mg} \cdot \mathrm{kg}^{-1}$ for 6 pesticides. SDL obtained for PAPs coincided with those for feed ingredients, feed and fish in 136 cases $(84 \%)$ and for the rest showed worst results except for hexaflumuron, butachlor and omethoate.

In general, the evaluation of the SDL for ethoxyquin (ETQ) was troublesome due to the presence of the analyte at high concentrations in the samples used for validation.

Table S2. SDLs estimated by GC-APCI-QTOF MS for the pesticides based on ${ }^{\text {a) }} 20$ different sample matrices (feed ingredients, feed and fish), ${ }^{\text {b) }}$ widen with 4 additional samples (gilthead sea bream fillet, salmon fillet and two additional fish feed) and ${ }^{\mathrm{c}} 6$ PAPs samples.

\begin{tabular}{|c|c|c|c|c|c|}
\hline & & & $\mathrm{n}=20^{\mathrm{a}}$ & $\mathrm{n}=4^{\mathrm{b}}$ & $\mathrm{n}=6^{\mathrm{c}}$ \\
\hline 2-Phenylphenol & Diazinon & Parathion ethyl & \multirow{22}{*}{0.01} & \multirow{22}{*}{0.01} & \multirow{22}{*}{0.01} \\
\hline 4-4'-Dichlorobenzophenone & Dichlofenthion & Parathion methyl & & & \\
\hline Alachlor* & Dichloran & Pirimicarb & & & \\
\hline Atrazine & Dichlorvos & Pirimiphos methyl & & & \\
\hline Atrazine desethyl & Diflufenican & Procymidone & & & \\
\hline Atrazine desisopropyl & Endosulfan ether & Propham* & & & \\
\hline Azoxystrobin & EPN & Propiconazole & & & \\
\hline Bifenthrin* & Ethalfluralin & Propyzamide & & & \\
\hline Bromophos & Etofenprox* & Pyriproxyfen & & & \\
\hline Bromophos ethyl & Famphur & Quinalphos & & & \\
\hline Bromopropilate & Fenarimol & Resmethrin & & & \\
\hline Buprofezin & Fenitrothion & Simazine & & & \\
\hline Carfentrazone ethyl & Fenoxycarb & Terbacil* & & & \\
\hline Chinomethionat & Fenthion & Terbumeton & & & \\
\hline Chlorfenapyr & Fipronil & Terbumeton desethyl & & & \\
\hline Chlorfenvinphos & Folpet & Terbuthylazine desethyl & & & \\
\hline Chlorpropham* & Metalaxyl & Terbutryn & & & \\
\hline Chlorpyrifos ethyl & Methoxychlor* & Tetradifon & & & \\
\hline Chlorpyrifos methyl & Metolachlor & Tolclofos methyl & & & \\
\hline Coumaphos & Metribuzin & Triadimefon & & & \\
\hline Cyanophos & Molinate & Trifluralin & & & \\
\hline Cyprodinil & Oxyfluorfen & Vinclozolin & & & \\
\hline \multirow[t]{2}{*}{ Iprodione } & Malathion & Methiocarb* & 0.01 & 0.01 & 0.05 \\
\hline & Diphenylamine & Leptophos & 0.01 & - & - \\
\hline alpha-endosulphan & Endrin & p,p'-DDE & & & \\
\hline alpha-HCH* & Flucythrinate* & p,p'-DDT* & 0.05 & 0.05 & 0.05 \\
\hline beta-endosulfan & Fludioxonil & Pentachlorobenzene & & & \\
\hline
\end{tabular}


Table S2. (continuation)

\begin{tabular}{|c|c|c|c|c|c|}
\hline & & & $\mathrm{n}=20^{\mathrm{a}}$ & $\mathrm{n}=4^{\mathrm{b}}$ & $\mathrm{n}=6^{\mathrm{c}}$ \\
\hline beta-HCH* & gamma-HCH * & Phosmet & \multirow{6}{*}{0.05} & \multirow{6}{*}{0.05} & \multirow{6}{*}{0.05} \\
\hline Cadusafos & HCB & Tefluthrin & & & \\
\hline Carbaryl* & Heptachlor & Thiabendazole & & & \\
\hline delta-HCH* & lamba-Cyhalothrin & Permethrin* & & & \\
\hline Dieldrin & Methamidophos & & & & \\
\hline Dimethoate & p,p'-DDD* & & & & \\
\hline Carbofuran* & Phorate & Ethion & \multirow{3}{*}{0.05} & \multirow{3}{*}{0.05} & \multirow{3}{*}{0.01} \\
\hline Dioxathion* & Terbuthylazine & Fenamiphos & & & \\
\hline Oxadixyl & Cyanazine & Triflumizole & & & \\
\hline Chlorothalonil & Heptachlor epoxide B & Propoxur & \multirow{2}{*}{0.05} & \multirow{2}{*}{-} & \multirow{2}{*}{-} \\
\hline Heptachlor epoxide A & & & & & \\
\hline & Pendimethalin & Carbophenothion & - & 0.05 & 0.05 \\
\hline & Chlorfenson & tau-Fluvalinate & - & 0.05 & 0.01 \\
\hline \multirow[t]{2}{*}{ Cyfluthrin } & Deltamethrin & Endosulfan sulfate & - & - & 0.05 \\
\hline & & Ethoxyquin & $*$ & $*$ & $*$ \\
\hline Aldrin & Fenvalerate & Mirex* & - & - & - \\
\hline Azinphos methyl & Hexachlorobutadiene & Propetamphos & & & \\
\hline Captafol & Imazalil & Tolyfluanid* & & & \\
\hline Captan* & Isodrin & trans-Chlordane & & & \\
\hline Cypermethrin & Methidathion & & & & \\
\hline Azaconazole & Epoxyconazol & Propazine & & 0.01 & 0.01 \\
\hline Bromuconazole & Fluquinconazole & Prosulfocarb & & & \\
\hline Clodinafop-propargyl & Isopyrazam & Tebuconazole & & & \\
\hline Cyproconazole & Mephosfolan & & & & \\
\hline Dimethachlor & Metconazole & & & & \\
\hline Bixafen & Iprovalicarb & Pyraclostrobin & & 0.05 & 0.01 \\
\hline Difenoconazole & Mepanipyrim & Tepraloxydim & & & \\
\hline Indoxacarb & Metrafenon & & & & \\
\hline Ioxynil-Octanoate & Profenofos & & & & \\
\hline Carbetamide & Methabenzthiazuron & Quintocene & & 0.05 & 0.05 \\
\hline Fenpropimorph & Procloraz & & & & \\
\hline Isoxaben & Pymetrozine & & & & \\
\hline Acequinocyl $^{*}$ & Chlordecone & Oxydemeton-methyl* & & - & - \\
\hline Bromoxynyl & Flumetrine* & Prothioconazole & & & \\
\hline Carbosulfan & Ioxonyl & Spiromesifen & & & \\
\hline
\end{tabular}

* monitored as a fragment ion bold: charge transfer conditions 
Table S3. SDLs estimated by UHPLC-QTOF MS for the pesticides based on a) 20 different sample matrices (feed ingredients, feed and fish), ${ }^{\text {b) }}$ widen with 4 additional samples (gilthead sea bream fillet, salmon fillet and two additional fish feed) and ${ }^{\text {c) }} 6$ PAPs samples.

\begin{tabular}{|c|c|c|c|c|c|}
\hline & & & $\mathrm{n}=20^{\mathrm{a}}$ & $\mathrm{n}=4^{\mathrm{b}}$ & $\mathrm{n}=6^{\mathrm{c}}$ \\
\hline $\begin{array}{l}\text { Atrazine } \\
\text { Bentazone (-) } \\
\text { Buprofezin } \\
\text { Cadusafos } \\
\text { Carbaryl } \\
\text { Carbofuran } \\
\text { Clomazone } \\
\text { Coumaphos } \\
\text { Cyprodinil } \\
\text { Dichlorvos } \\
\text { Terbuthylazine desethyl } \\
\text { Diazinon } \\
\text { Dimethomorph } \\
\text { Fenamiphos }\end{array}$ & $\begin{array}{l}\text { Fipronil (-) } \\
\text { Fludioxonil (-) } \\
\text { Fluazifop-P-butyl } \\
\text { Flutriafol } \\
\text { Haloxyfop-2-ethoxyethyl } \\
\text { Imazalil } \\
\text { Linuron } \\
\text { Malaoxon } \\
\text { Malathion } \\
\text { Metolachlor } \\
\text { Paclobutrazol } \\
\text { Pirimicarb } \\
\text { Pirimiphos-methyl }\end{array}$ & $\begin{array}{l}\text { Promecarb } \\
\text { Pyrifenox } \\
\text { Propanil (-) } \\
\text { Pyridaphenthion } \\
\text { Pyriproxyfen } \\
\text { Quinalphos } \\
\text { Simazine } \\
\text { Tebuconazole } \\
\text { Terbumeton } \\
\text { Terbuthylazine } \\
\text { Terbutryn } \\
\text { Thiobencarb } \\
\text { Triflumizole }\end{array}$ & 0.01 & 0.01 & 0.01 \\
\hline $\begin{array}{l}\text { Dicrotophos } \\
\text { Fluazinam (-) } \\
\text { Haloxyfop-methyl }\end{array}$ & $\begin{array}{l}\text { Isoproturon } \\
\text { Metalaxyl } \\
\text { Propiconazole } \\
\end{array}$ & $\begin{array}{l}\text { Teflubenzuron (-) } \\
\text { Tetraconazole }\end{array}$ & 0.01 & 0.01 & 0.05 \\
\hline Haloxyfop-methyl & & Azinphos-methyl & 0.01 & 0.01 & - \\
\hline $\begin{array}{l}\text { Azoxystrobin } \\
\text { Chlorfenvinphos }\end{array}$ & Quizalofop-ethyl & Triadimenol & 0.01 & 0.05 & 0.05 \\
\hline $\begin{array}{l}\text { Bensulide } \\
\text { Fenoxycarb } \\
\end{array}$ & Spiroxamine & Thiodicarb & 0.01 & 0.05 & - \\
\hline $\begin{array}{l}\text { Atrazine desisopropyl } \\
\text { Boscalid } \\
\text { Carfentrazone ethyl } \\
\text { Chlorsulfuron } \\
\text { Diflubenzuron } \\
\text { Diflufenican } \\
\text { Diuron } \\
\text { Ethiofencarb } \\
\text { Ethion } \\
\text { Ethofumesate }\end{array}$ & $\begin{array}{l}\text { Ethoxyquin dimer } \\
\text { Fenhexamid } \\
\text { Fenoxaprop } \\
\text { Fenthion } \\
\text { Flufenoxuron } \\
\text { Methidathion } \\
\text { Methiocarb } \\
\text { Mevinphos } \\
\text { Monocrotophos } \\
\text { Oxadixyl }\end{array}$ & $\begin{array}{l}\text { Pendimethalin } \\
\text { Simazine } \\
\text { Tebufenpyrad } \\
\text { Terbacil (-) } \\
\text { Terbumeton desethyl } \\
\text { Thiabendazole } \\
\text { Thiacloprid } \\
\text { Thiophanate-methyl } \\
\text { Tolclofos-methyl } \\
\text { Tridemorph }\end{array}$ & 0.05 & 0.05 & 0.05 \\
\hline \multirow{3}{*}{ Ethofumesate } & & Hexaflumuron (-) & 0.05 & 0.05 & 0.01 \\
\hline & Chlorpropham & Parathion-ethyl & 0.05 & - & - \\
\hline & Butachlor & Omethoate & - & 0.05 & 0.05 \\
\hline $\begin{array}{l}\text { Acetamiprid } \\
\text { Aldicarb sulfone } \\
\text { Atrazine desethyl }\end{array}$ & $\begin{array}{l}\text { Clothianidin } \\
\text { Ethiofencarb sulfoxide } \\
\text { Hexythiazox }\end{array}$ & $\begin{array}{l}\text { Methiocarb sulfoxide } \\
\text { Propamocarb }\end{array}$ & - & 0.05 & - \\
\hline & & Ethoxyquin & $*$ & $*$ & $*$ \\
\hline $\begin{array}{l}\text { Simazine 2-hydroxy- } \\
\text { Terbuthylazine 2-hydroxy- }\end{array}$ & $\begin{array}{l}\text { Chloridazon } \\
\text { Ethiofencarb sulfone }\end{array}$ & $\begin{array}{l}\text { Oxamyl } \\
\text { Terbufos }\end{array}$ & - & - & - \\
\hline
\end{tabular}


Table S3. (continuation)

\begin{tabular}{|c|c|c|c|c|c|}
\hline & & & \\
\hline & & & $\mathrm{n}=20^{\mathrm{a}}$ & $\mathrm{n}=4^{\mathrm{b}}$ & $\mathrm{n}=6^{\mathrm{c}}$ \\
\hline Aldicarb sulfoxide & Fluroxypyr & Thiamethoxam & \multirow{5}{*}{-} & \multirow{5}{*}{-} & \multirow{5}{*}{-} \\
\hline Azinphos-ethyl & Imidacloprid & Thiram & & & \\
\hline Benomyl & Lufenuron & Tolyfluanid & & & \\
\hline Bifenazate & MCPA (-) & Trichlorfon & & & \\
\hline Butocarboxym & Methamidophos & Triforine & & & \\
\hline Carbendazim & \multirow{2}{*}{\multicolumn{2}{|c|}{$\begin{array}{l}\text { Methiocarb sulfone } \\
\text { Methomyl }\end{array}$}} & \multirow{2}{*}{-} & \multirow{2}{*}{ - } & \multirow{2}{*}{ - } \\
\hline Carbofuran-3-OH & & & & & \\
\hline Azaconazole & Fenpropimorph & Mephosfolane & & \multirow{2}{*}{0.01} & \multirow{2}{*}{0.05} \\
\hline Cyproconazole & Mepanipyrim & Propazine & & & \\
\hline Aldicarb & Ioxynil (-) & Prosulfocarb & & \multirow{8}{*}{0.05} & \multirow{8}{*}{0.05} \\
\hline Bixafen & Isoxaben & Pyraclostrobin & & & \\
\hline Bromuconazole & Metconazole & Tebufenozide & & & \\
\hline Clodinafop-Propargyl & Methabenzthiazuron & Tepraloxydim & & & \\
\hline Difenoconazole & Metrafenone & & & & \\
\hline Dimetachlor & Oxydemeton-methyl & & & & \\
\hline Fluquinconazole & Prochloraz & & & & \\
\hline Indoxacarb & Profenofos & & & & \\
\hline $\begin{array}{l}\text { Carbetamide } \\
\text { Iprovalicarb }\end{array}$ & Isopyrazam & Prothioconazole & & 0.05 & - \\
\hline Benoxacor & Carbosulfan & Pymethrozine & & & \\
\hline Bromoxynil (-) & Dalapon (-) & Trinexapac acid (-) & & - & - \\
\hline
\end{tabular}

* monitored as a fragment ion

bold: ESI in negative mode

It is worth to mention that in some cases the same pesticide was included in both screening methodologies, LC and GC. In those cases, the most favorable SDL was selected. In this way, Table 1 summarizes the final SDLs established for feed ingredient, feed and fish for the 252 pesticides studied (removing duplicities resulting from LC and GC analysis of the same compound). Overall, SDL values were $0.01 \mathrm{mg} \cdot \mathrm{kg}^{-1}$ for 113 pesticides $(45 \%), 0.05 \mathrm{mg} \cdot \mathrm{kg}^{-}$ ${ }^{1}$ for 73 pesticides (29\%) and a total of 66 pesticides could not be qualitatively validated $(26 \%)$ at these levels. For most of them, surely the method was not sensitive enough for the analyte/matrix tested, and higher analyte concentrations $\left(>0.05 \mathrm{mg} \cdot \mathrm{kg}^{-1}\right)$ should be tested. In addition, some pesticides and sample matrices might require specific sample treatments and/or 
measurement conditions in order to reach the low concentration levels tested

in this work.

Table 1. SDLs obtained for each pesticide studied by GC-APCI-QTOF MS and UHPLC-ESI-QTOF MS.

\begin{tabular}{|c|c|c|c|}
\hline $0.01 \mathrm{mg} \cdot \mathrm{kg}^{-1}$ & & $0.05 \mathrm{mg} \cdot \mathrm{kg}^{-1}$ & $>0.05 \mathrm{mg} \cdot \mathrm{kg}^{-1}$ \\
\hline 2-Phenylphenol & Folpet & alpha-endosulphan & Acetamiprid \\
\hline 4-4'-Dichlorobenzophenone & Haloxyfop-2-ethoxyethyl & alpha-HCH* & Aldicarb sulfone \\
\hline Alachlor* & Haloxyfop-methyl & Bensulide & Aldicarb sulfoxide \\
\hline Atrazine desethyl & Imazalil & beta-endosulfan & Aldrin \\
\hline Atrazine desisopropyl & Iprodione & beta-HCH* & Azinphos-ethyl \\
\hline Atrazine/Atrazine & Isoproturon & Boscalid & Benomyl \\
\hline Azinphos-methyl & Linuron & Chlorsulfuron & Bifenazate \\
\hline Azoxystrobin & Malaoxon & Cyanazine & Butachlor \\
\hline Bentazone (-) & Malathion/Malathion & delta-HCH* & Butocarboxym \\
\hline Bifenthrin* & Metalaxyl/Metalaxyl & Dieldrin & Captafol \\
\hline Bromophos & Methiocarb* & Diflubenzuron & Captan* \\
\hline Bromophos ethyl & Methoxychlor* & Dimethoate & Carbendazim \\
\hline Bromopropylate & Metolachlor/Metolachlor & Dioxathion* & Carbofuran-3-OH \\
\hline Buprofezin/Buprofezin & Metribuzin & Diuron & Carbophenothion \\
\hline Cadusafos & Molinate & Endrin & Chlorfenson \\
\hline Carbaryl & Oxyfluorfen & Ethiofencarb & Chloridazon \\
\hline Carbofuran & Paclobutrazol & Ethion/Ethion & Chlorothalonil \\
\hline Carfentrazone ethyl & Parathion ethyl & Ethofumesate & Clothianidin \\
\hline Chinomethionat & Parathion methyl & Ethoxyquin dimer & Cyfluthrin \\
\hline Chlorfenapyr & Pirimicarb/Pirimicarb & Fenhexamid & Cypermethrin \\
\hline Chlorfenvinphos & Pirimiphos/Pirimiphos & Fenoxaprop & Deltamethrin \\
\hline Chlorpropham* & Procymidone & Flucythrinate* & Diphenylamine \\
\hline Chlorpyrifos ethyl & Promecarb & Flufenoxuron & Endosulfan sulfate \\
\hline Chlorpyrifos methyl & Propanil (-) & gamma-HCH* & Ethiofencarb sulfone \\
\hline Clomazone & Propham* & $H C B$ & Ethiofencarb sulfoxide \\
\hline Coumaphos/Coumaphos & Propiconazole/Propiconazole & Heptachlor & Ethoxyquin/Ethoxyquin \\
\hline Cyanophos & Propyzamide & Hexaflumuron (-) & Fenvalerate \\
\hline Cyprodinil/Cyprodinil & Pyridaphenthion & lambda-Cyhalothrin & Fluroxypyr \\
\hline Diazinon/Diazinon & Pyrifenox & Methamidophos & Heptachlor epoxide A \\
\hline Dichlofenthion & Pyriproxyfen/Pyriproxyfen & Methidathion & Heptachlor epoxide B \\
\hline Dichloran & Quinalphos/Quinalphos & Mevinphos & Hexachlorobutadiene \\
\hline Dichlorvos/Dichlorvos & Resmethrin & Monocrotophos & Hexythiazox \\
\hline Dicrotophos & Simazine/Simazine & Oxadixyl/Oxadixyl & Imidacloprid \\
\hline Diflufenican & Tebuconazole & $p, p^{\prime}-D D D^{*}$ & Isodrin \\
\hline Dimethomorph & Teflubenzuron (-) & $p, p^{\prime}-D D E$ & Leptophos \\
\hline Endosulfan ether & Terbacil* ${ }^{*}$ & $p, p^{\prime}-D D T^{*}$ & Lufenuron \\
\hline EPN & Terbumeton/Terbumeton & Pendimethalin & MCPA (-) \\
\hline Ethalfluralin & Terbumeton desethyl & Pentachlorobenzene & Methiocarb sulfone \\
\hline Etofenprox* & Terbuthylazine & Permethrin* & Methiocarb sulfoxide \\
\hline Famphur & $\begin{array}{l}\text { Terbuthylazine-desethyl } \\
\text { /Terbuthylazine-desethyl }\end{array}$ & Phorate & Methomyl \\
\hline Fenamiphos & Terbutryn/Terbutryn & Phosmet & Mirex* \\
\hline Fenarimol & Tetraconazole & Quizalofop-ethyl & Omethoate \\
\hline Fenitrothion & Tetradifon & Spiroxamine & Oxamyl \\
\hline Fenoxycarb & Thiobencarb & Tebufenpyrad & Propamocarb \\
\hline Fenthion & Tolclofos methyl & Tefluthrin & Propetamphos \\
\hline Fipronil/Fipronil (-) & Triadimefon & Terbacil (-) & Propoxur \\
\hline Fluazifop-P-butyl & Triflumizole & $\begin{array}{l}\text { Thiabendazole } \\
\text { /Thiabendazole }\end{array}$ & Simazine 2-hydroxy \\
\hline Fluazinam (-) & Trifluralin & Thiacloprid & tau-Fluvalinate \\
\hline Fludioxonil* (-) & Vinclozolin & Thiodicarb & Terbufos \\
\hline
\end{tabular}


Table 1. (continuation)

\begin{tabular}{|c|c|c|}
\hline $0.01 \mathrm{mg} \cdot \mathrm{kg}^{-1}$ & $0.05 \mathrm{mg} \cdot \mathrm{kg}^{-1}$ & $>0.05 \mathrm{mg} \cdot \mathrm{kg}^{-1}$ \\
\hline Flutriafol & $\begin{array}{l}\text { Thiophanate-methyl } \\
\text { Triadimenol } \\
\text { Tridemorph }\end{array}$ & $\begin{array}{l}\text { Terbuthylazine 2-OH } \\
\text { Thiamethoxam } \\
\text { Thiram } \\
\text { Tolyfluanid*/Tolyfluanid } \\
\text { trans-Chlordane } \\
\text { Trichlorfon } \\
\text { Triforine }\end{array}$ \\
\hline $0.01 \mathrm{mg} \cdot \mathrm{kg}^{-1}$ & $0.05 \mathrm{mg} \cdot \mathrm{kg}^{-1}$ & $>0.05 \mathrm{mg} \cdot \mathrm{kg}^{-1}$ \\
\hline Azaconazole/Azaconazole & Aldicarb & Acequinocyl \\
\hline Bromuconazole & Bixafen/Bixafen & Benoxacor \\
\hline Clodinafop-propargyl & Carbetamide/Carbetamide & Bromoxynyl/Bromoxynil (-) \\
\hline Cyproconazole/Cyproconazole & Carbosulfan/Carbosulfan & Iprovalicarb/Iprovalicarb \\
\hline Dimethachlor & Indoxacarb/Indoxacarb & Chlordecone \\
\hline Epoxyconazol & Ioxynil (-) & Dalapon (-) \\
\hline Fenpropimorph & Ioxynil-Octanoate & Flumetrine \\
\hline Fluquinconazole & Difenoconazole & Oxydemeton-methyl \\
\hline Isopyrazam & Isoxaben/Isoxaben & Spiromesifen \\
\hline Mepanipyrim & Methabenzthiazuron/Methabenzthiazuron & Trinexapac acid (-) \\
\hline Mephosfolan/Mephosfolan & Metrafenon/Metrafenone & \\
\hline Metconazole & Oxydemeton-methyl & \\
\hline Propazine/Propazine & Procloraz/Procloraz & \\
\hline Prosulfocarb & Profenofos/Profenofos & \\
\hline \multirow[t]{6}{*}{ Tebuconazole } & Prothioconazole & \\
\hline & Pymetrozine & \\
\hline & Pyraclostrobin/Pyraclostrobin & \\
\hline & Quintocene & \\
\hline & Tebufenozide & \\
\hline & Tepraloxydim/Tepraloxydim & \\
\hline
\end{tabular}

italic: GC under charge transfer conditions

bold: LC

*: ion fragment

(-): ESI neg

All the samples described in the experimental section, which contain ingredients from different origin (plant, terrestrial animals and marine), and also different feed compositions and fish tissues, were analyzed following the recommended procedure by both GC-(APCI)QTOF MS and UHPLC(ESI)QTOF MS. Fig. 2 illustrates the pesticides detected, identified (confirmed with reference standard) and tentatively identified in the screening of these aquaculture samples. 


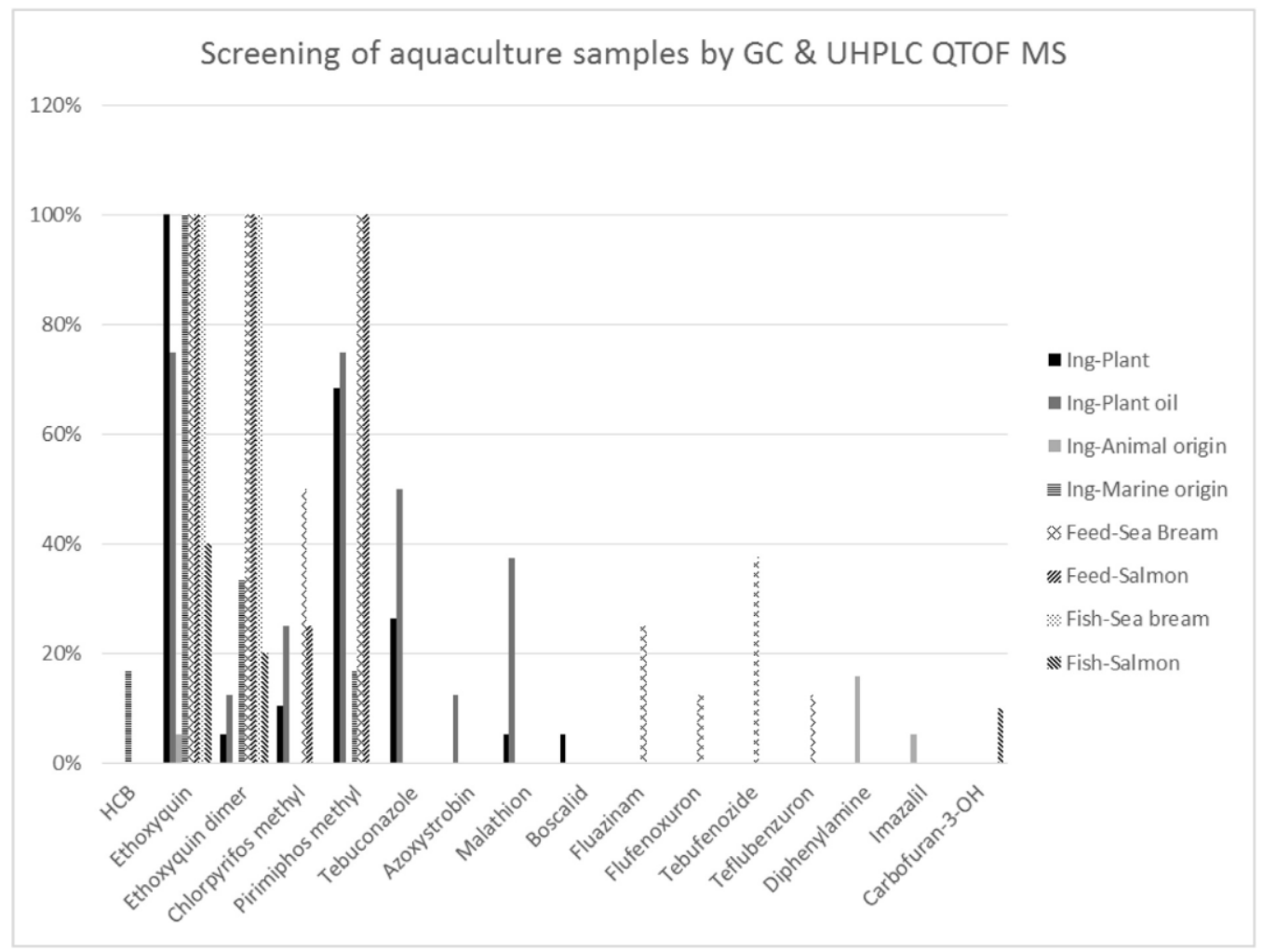

Fig. 2. Accumulated \% of samples positives to pesticides detected or identified in the screening of aquaculture samples by GC\&LC-QTOF MS.

Pirimiphos methyl, was the compound more frequently identified by both techniques in most ingredients (68\% of plant protein, $75 \%$ plant oil ingredients and $17 \%$ of marine ingredients) and in all the feed samples (salmon and sea bream). However, no residues were found in the fish samples suggesting none feed to fish fillet transfer. Similarly, chlorpyriphos methyl was detected, mainly by GC-(APCI)QTOF MS, in plant protein (11\%), plant oil ingredients (25\%), gilthead sea bream feed (50\%) and salmon feed (25\%) but not fish fillets. Foodborne chlorpyriphos-methyl is readily metabolized and eliminated by fish, and its relative low biomagnification potential compared to POPs (Varó et al., 2002) could explain the non-detectable fillet levels in fish that 
were fed on low background levels in the present study. In addition, long term storage at high temperatures could potentially affect the level of chlorpyrifosmethyl, but not pirimiphos-methyl residues in corn products (White et al., 1997). In the present trial, no assessment of the pesticide level during storage was made, which could have contributed to possible absence of detectable pesticides in the fish fillets of fish fed on the feeds. Earlier surveillance studies also identified chlorpyriphos methyl, and to a lesser extend pirimiphos methyl, as some of the most frequent pesticide residues in terrestrial animal feeds (Gómez-Pérez et al., 2015; Lovell et al., 1996). In contrast to the present study, chlorpyriphos-methyl was also detected in fish from Taiwan markets and fish feeds were suggested to be the main source of this compound in farmed fish (Sun and Chen, 2008).

Other pesticides like the organochlorine pesticide $\mathrm{HCB}$ was found by GC(APCI)QTOF MS in one marine origin ingredient, which is a well-known OCP pesticide that behaves as a POP with elevated levels in fish oil obtained from pelagic fish species (Berntssen et al., 2010). The none-OCP pesticides, tebuconazole, azoxystrobin, malathion and boscalid were found by UHPLC(ESI) QTOF MS in plant-based ingredients (specially in plant oil ingredients). In contrast to chlorpyriphos-methyl and pirimiphos-methyl, these pesticides were not found in feed samples. The absence of these pesticides in feed while present in the plant-based feed ingredients is likely due to the dilution effect occurred when plant ingredients are mixed with other ingredients such as fish oil and meal to produce fish feeds, causing levels below SDL. Then, flufenoxuron, tebufenozide and teflubenzuron were identified (tebufenozide only detected) by UHPLC-(ESI)QTOF MS in gilthead sea bream feed samples (among 13 and 38\% of the analyzed samples), but not in the feed ingredients used in these feeds or fillets of seabream fed on these feeds. Ethoxyquin, which 
use is currently authorized as a feed ingredient antioxidant supplement, was identified in all samples by both techniques except plant oil ingredients $(75 \%)$ and animal origin ingredients (only in 5\%).

All cited compounds had been included in the target screening list, as reference standards were available for them and had been previously included in the qualitative screening validation protocol. Oppositely, the fungicide fluazinam, included in the suspect list, was tentatively identified by UHPLC(ESI)QTOF MS in two gilthead sea bream feed samples. Fig. 3 illustrates the detection and tentative identification of this compound in a gilthead sea bream feed sample by UHPLC-QTOF MS. The deprotonated molecule of fluazinam was detected in the LE function in ESI negative mode, with a mass error of $1.9 \mathrm{ppm}$. As the reference standard was not available, chemical structures for the most abundant fragment ions were suggested based on their accurate masses, using the Mass-Fragment software (Waters). In the HE function, 2 fragments $(\mathrm{m} / \mathrm{z} 415.9433$ and 397.9768) were observed with chromatographic peaks at the same Rt, and mass errors lower than $1.2 \mathrm{ppm}$ in relation to the theoretical predicted exact masses. All structures proposed for the fragments were compatible with the chemical structure of fluazinam and were in accordance with the isotopic pattern observed for the chlorine atoms present in the structure, making the identification even more reliable. Moreover, the tentative identification was supported by the MS/MS product ions reported in the literature (Pizzutti et al., 2009). After this careful evaluation process, the reference standard was finally acquired and injected, allowing the ultimate confirmation of this compound in the sample. 


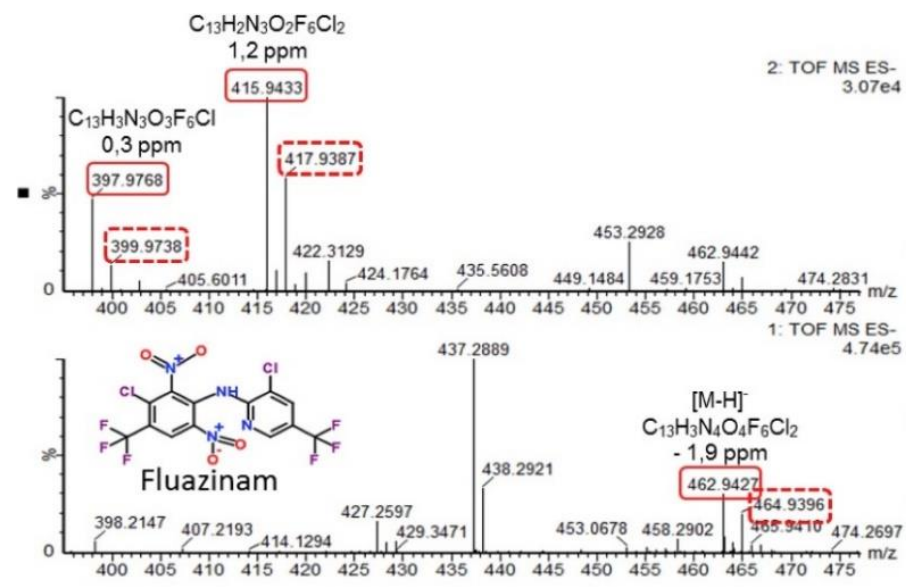

(A)

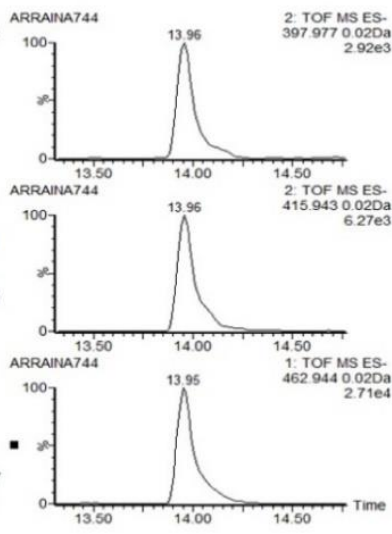

(B)

Fig. 3. Detection and identification of fungicide fluazinam by UHPLC-QTOF MS in a gilthead sea bream feed sample (the reference standard was not available at our laboratory in the time of the detection): (a) LE (bottom) and HE (top) spectra of the compound eluting at $13.96 \mathrm{~min}$. Proposed elemental compositions for fragment ions; (b) extracted-ion chromatograms (150 ppm mass width) for protonated molecule in LE function and different fragment ions in HE function

\subsection{Quantitative analysis of identified pesticides and feed-to fillet transfer}

QC recoveries were obtained at 0.005 and $0.05 \mathrm{mg} \cdot \mathrm{kg}^{-1}$ in 19 different matrices, ranging between $60 \%$ and $130 \%$ for most matrix/analyte combinations. A LOQ of $0.005 \mathrm{mg} \cdot \mathrm{kg}^{-1}$ was obtained for azoxystrobin, boscalid, malathion, pirimiphos-methyl, chlorpyriphos-methyl and ethoxyquin-dimer (ETQ-D) while it was $0.05 \mathrm{mg} \cdot \mathrm{kg}^{-1}$ for diphenylamine, tebuconazole and imazalil, this being the lower MRL established in the current legislation for crops that can be used as feed ingredients. Regarding ethoxyquin, the evaluation of its recovery was not feasible due to the presence of the analyte at high concentrations in the samples used for validation. For the remaining two compounds, fluazinam and hexachlorobenzene, the method 
was not suitable as they did not present satisfactory results in most of the matrices.

All compounds reported as identified by QTOF screening were confirmed and quantified by GC-(APCI)MS/MS. The only exceptions were fluazinam (2 samples), flufenoxuron (1 sample), teflubenzuron (1 sample) and carbofuran$3 \mathrm{OH}$ ( 1 sample) which were identified by UHPLC-QTOF MS but could not be included in GC-(APCI)MS/MS quantitative method due to their physicochemical characteristics. Additionally, there were another 37 detections in the screening, for which only one ion measured at accurate mass at expected Rt was found and therefore their identity could not be confirmed. 22 out of these 37 suspect positives could be confirmed and quantified by QqQ while for rest seemed to be false detections. The greater sensitivity of GC-MS/MS with QqQ in comparison to QTOF made it possible to report 47 new positive findings that had not been detected previously or identified by QTOF (ethoxyquin, ethoxyquin-dimer, boscalid, azoxystrobin, tebuconazole and imazalil). All of them were quantified by QqQ at levels below $0.05 \mathrm{mg} \cdot \mathrm{kg}^{-1}$ except for ethoxyquin and ethoxyquin-dimer whose concentrations exceeded 0.05 $\mathrm{mg} \cdot \mathrm{kg}^{-1}$ in most of the salmon fillets analyzed. As regards identification, all quantified pesticides were identified by the use of three transitions and the compliance of at least one $\mathrm{q} / \mathrm{Q}$ ratio.

Table 2 summarizes the pesticide concentrations determined in the analyzed samples by GC-(APCI)MS/MS. Ethoxyquin and ethoxyquin-dimer were found in all feed and fish samples. Concentrations were above $0.5 \mathrm{mg} \cdot \mathrm{kg}^{-1}$ in all feeds, in the range of $0.005-0.5 \mathrm{mg} \cdot \mathrm{kg}^{-1}$ in salmon fillet and above 0.05 $\mathrm{mg} \cdot \mathrm{kg}^{-1}$ in gilthead sea bream. ETQ was found at concentration levels above $0.05 \mathrm{mg} \cdot \mathrm{kg}^{-1}$ in all ingredients with the exception of one plant ingredient in 
the range of $0.005-0.05 \mathrm{mg} \cdot \mathrm{kg}^{-1}$. ETQ-D was found below $0.005 \mathrm{mg} \cdot \mathrm{kg}^{-1}$ except four plant ingredients in the range of $0.005-0.05 \mathrm{mg} \cdot \mathrm{kg}^{-1}$ and, above $0.005 \mathrm{mg} \cdot \mathrm{kg}^{-1}$ in all marine origin ingredients. Earlier studies also reported the overall presence of synthetic antioxidants such as ETQ in commercial feed and ETQ and ETQ-D in farmed fish including Atlantic salmon, halibut, cod, and rainbow trout, with mean (min.-max.) ETQ feed levels of 10 (1.4-32) $\mathrm{mg} \cdot \mathrm{kg}^{-1}$ and mean (min.-max.) ETQ and ETQ-D levels of 0.06 (0.013-0.17) and $0.7(0.29-1.5) \mathrm{mg} \cdot \mathrm{kg}^{-1}$, respectively, analyzed by means of HPLC coupled to fluorescence detection (Lundebye et al., 2010).

A concentration level around $0.01 \mathrm{mg} \cdot \mathrm{kg}^{-1}$ of fungicides boscalid and azoxystrobin were found in one feed sample $\left(0.009 \mathrm{mg} \cdot \mathrm{kg}^{-1}\right.$ for both analytes), one PAP (0.007 and $0.008 \mathrm{mg} \cdot \mathrm{kg}^{-1}$ respectively) and one plant oil (only boscalid at $0.007 \mathrm{mg} \cdot \mathrm{kg}^{-1}$ ) although not exceeding its MRL. The organophosphorous insecticides pirimiphos-methyl and chlorpyriphos-methyl were found in $66 \%$ and $25 \%$ of the feed samples in a range of $0.006-0.030$ $\mathrm{mg} \cdot \mathrm{kg}^{-1}$ and $0.005-0.009 \mathrm{mg} \cdot \mathrm{kg}^{-1}$, respectively. The highest concentration level of these two OP insecticides was found in a wheat gluten sample at 0.037 $\mathrm{mg} \cdot \mathrm{kg}^{-1}$ for chlorpyriphos-methyl and $0.191 \mathrm{mg} \cdot \mathrm{kg}^{-1}$ for pirimiphos-methyl. Additionally, pirimiphos-methyl was also found in five plant oil and three plant ingredient samples at concentration levels among $0.005-0.5 \mathrm{mg} \cdot \mathrm{kg}^{-1}$. No MRL exists for crop partly or exclusively used for feed ingredients (EC, 2013a). Until specific feed ingredient MRLs have been established, existing EU MRLs for food crop would apply, taking into account an appropriate processing (EFSA, 2015). As no standard factors are known for the processing of whole wheat into animal feed graded wheat gluten, no clear MRL can be set. However the wheat MRLs for chlorpyriphos-methyl and pirimiphosmethyl are respectively 3.0 and $5.0 \mathrm{mg} \cdot \mathrm{kg}^{-1}$ which is respectively 25 and 135 - 
fold higher than levels found in present study. Regarding tebuconazole, it was found in two rapeseed oil samples at concentration around $0.01 \mathrm{mg} \cdot \mathrm{kg}^{-1}$. As an illustrative example, Fig. 4 shows the GC-(APCI)MS/MS chromatograms obtained for the quantification and confirmation of boscalid in one salmon feed $\left(0.009 \mathrm{mg} \cdot \mathrm{kg}^{-1}\right)$, azoxystrobin in a poultry blood meal $\left(0.008 \mathrm{mg} \cdot \mathrm{kg}^{-1}\right)$ and chlorpyriphos-methyl in wheat gluten $\left(0.037 \mathrm{mg} \cdot \mathrm{kg}^{-1}\right)$. Also, Fig. S1 (a) shows the GC-(APCI)MS/MS chromatograms obtained for the quantification and confirmation of pirimiphos-methyl in wheat gluten at concentration level of $0.191 \mathrm{mg} \cdot \mathrm{kg}^{-1}$. This ingredient is used to prepare a gilthead sea bream feed shown at Fig. S1 (b) that contains the pirimiphos-methyl at concentration level of $0.007 \mathrm{mg} \cdot \mathrm{kg}^{-1}$. This feed represents a total replacement of $80 \%$ of fish meal by plant meal and $84 \%$ of the fish oil by alternative plant oils. The gilthead sea bream fish fillet reared on this feed does not shown any trace of pirimiphos methyl (Fig. S1(c)).

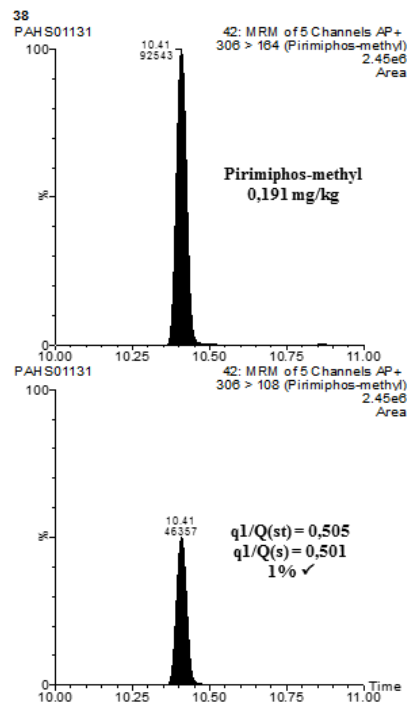

(A)

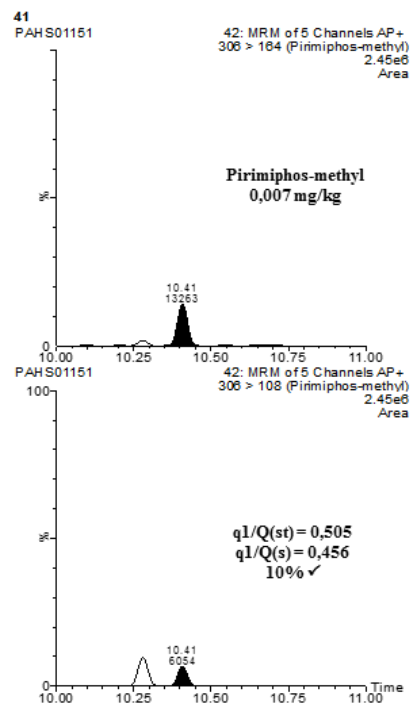

(B)

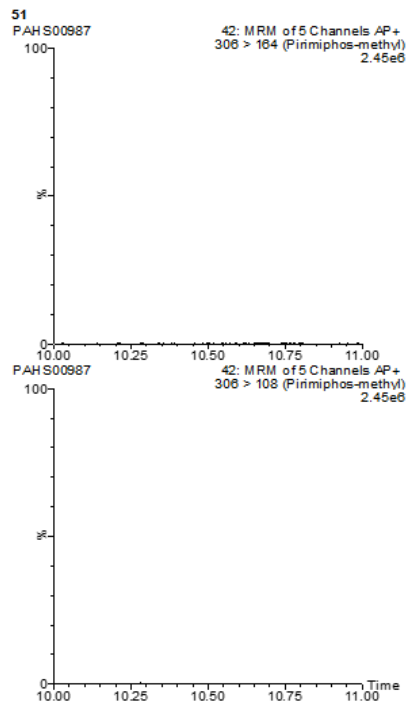

(C)

Figure S1. GC-APCI-MS/MS chromatograms obtained for the quantification and confirmation of pirimiphos-methyl in (a) plant ingredient, (b) feed and (c) gilthead sea bream fish fillet. Q: Quantification transition; $\mathrm{q}_{\mathrm{i}}$ : qualification transition. $\checkmark$ q/Q within accepted tolerances. 


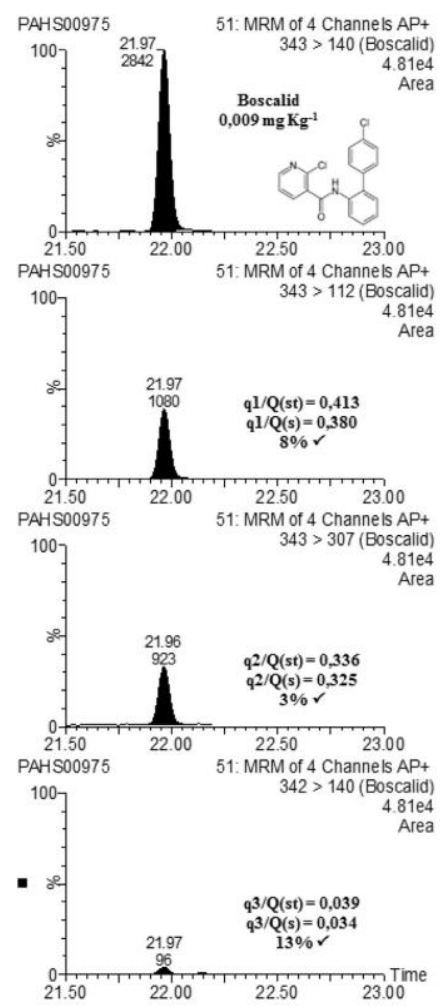

(A)

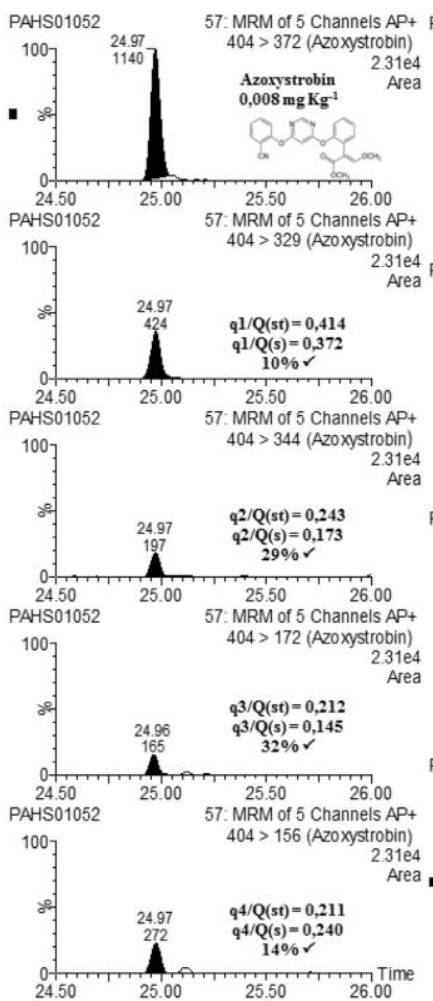

(B)

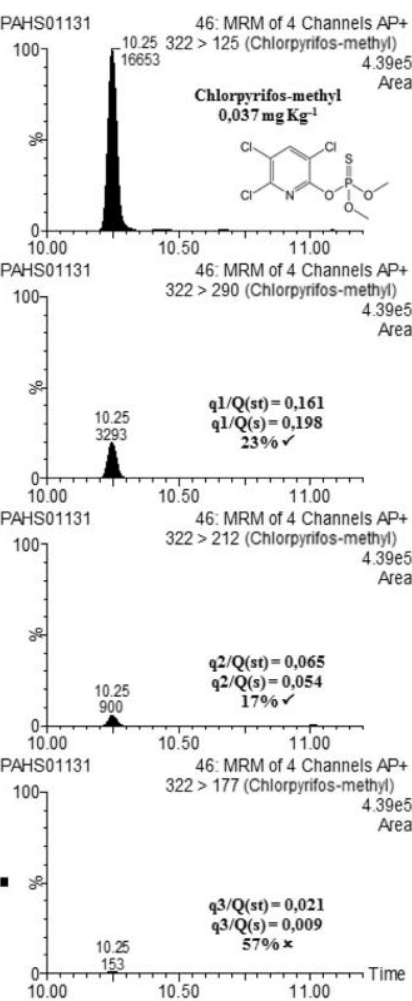

(C)

Fig. 4. GC-(APCI)MS/MS chromatograms obtained for the quantification and confirmation of boscalid in a) feed $\left(0.009 \mathrm{mg} \cdot \mathrm{kg}^{-1}\right)$; b) azoxystrobin in animal origin ingredient $\left(0.008 \mathrm{mg} \cdot \mathrm{kg}^{-1}\right)$ and; c) chlorpyriphos-methyl in plant oil $\left(0.037 \mathrm{mg} \cdot \mathrm{kg}^{-1}\right)$. Q: Quantification transition; qi: qualification transitions. $\checkmark$ q/Q within accepted tolerances. 


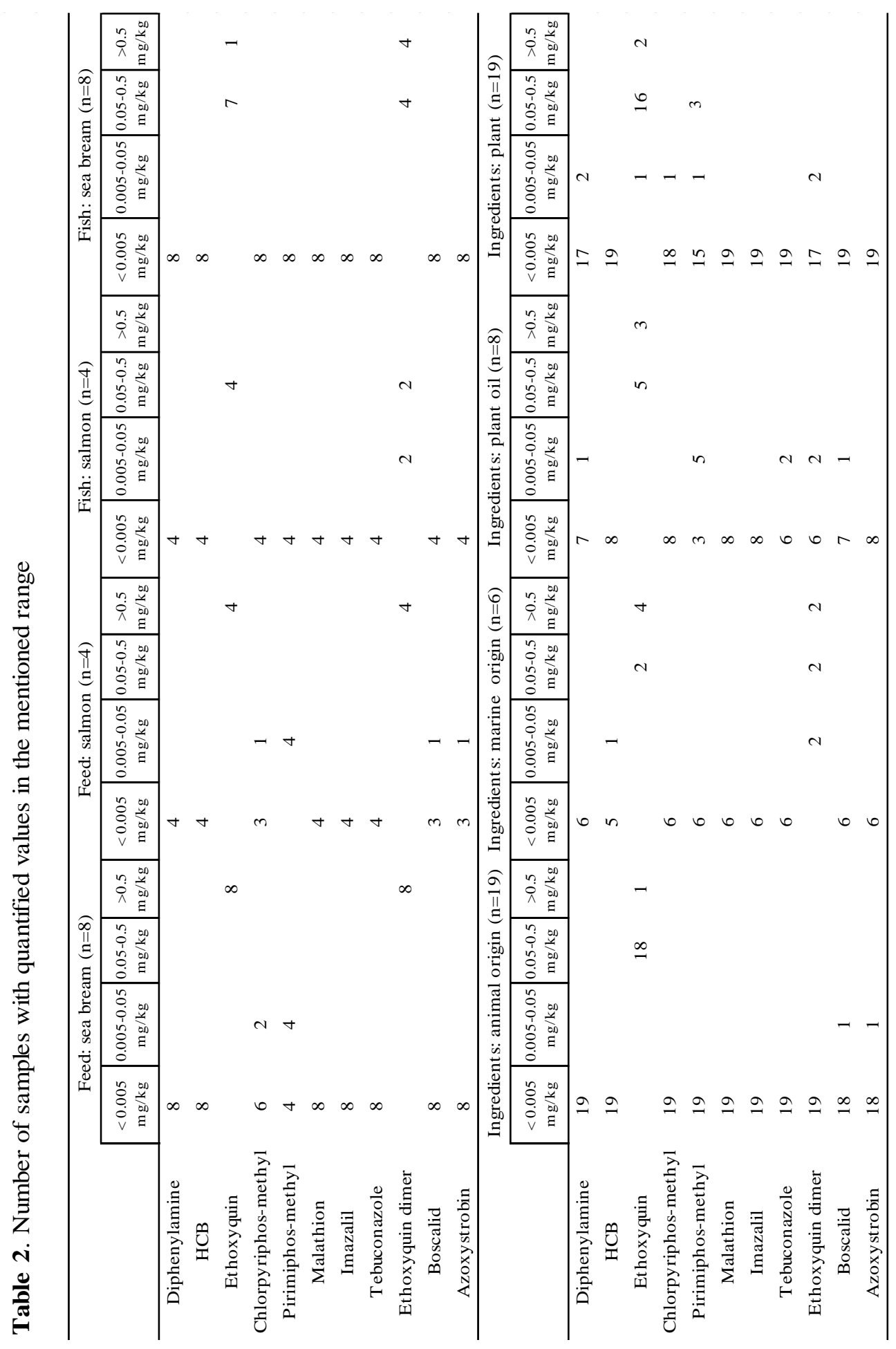




\section{Conclusions}

The developed strategy faces the "universal" pesticide analysis in aquaculture field by means of combined use of LC-QTOF MS and GC-QTOF MS for screening, followed by confirmation and quantification by GC-(APCI)MS/MS with QqQ, as most pesticide detected in the screening were GC-amenable. The strategy proposed is among the most comprehensive and informative in the pesticide analysis context as it covers a large list of pesticides from different families. The overall strategy is presented as a risk assessment tool available for the feed industry in order to widen the knowledge of novel and traditional ingredients, feed and edible parts of consumed animals. The most dominant polar pesticides found in plant feed ingredients and feed based on these ingredients were pirimiphos-methyl and chlorpyriphos-metyl. These pesticides were not found in the fillets of fish fed on these feeds.

\section{Acknowledgments}

This work has been funded by the EU Seventh Framework Programme ARRAINA Project 288925 (Advanced Research Initiatives for Nutrition and Aquaculture), and the Norwegian Research Council SAFETY-PAP project (227387) from the Sustainable Innovation in Food and Bio-based Industries (Bionær) program. Additional funding was obtained from Generalitat Valenciana (research group of excellence PROMETEOII/2014/085; PROMETEOII/2014/ 023; ISIC 2012/016). This work has been developed within the framework of the Research Unit of Marine Ecotoxicology (IATS (CSIC)-IUPA (UJI)). 


\section{References}

Benedito-Palos, L., Ballester-Lozano, G.F., Simó, P., Karalazos, V., Ortiz, Á., Calduch-Giner, J., Pérez-Sánchez, J., 2016. Lasting effects of butyrate and low FM/FO diets on growth performance, blood haematology/biochemistry and molecular growth-related markers in gilthead sea bream (Sparus aurata). Aquaculture 454, 8-18. http://dx.doi.org/10.1016/j.aquaculture.2015.12.008.

Berntssen, M.H.G., Julshamn, K., Lundebye, A.-K., 2010. Chemical contaminants in aquafeeds and Atlantic salmon (Salmo salar) following the use of traditional-versus alternative feed ingredients. Chemosphere 78, 637646. http://dx.doi.org/10.1016/j.chemosphere.2009.12.021.

Castillo, N.I., Ibáñez, M., Beltrán, E., Rivera-Monroy, J., Ochoa, J.C., PáezCastillo, M., Posada-Buitrago, M.L., Sulyok, M., Hernández, F., 2016. Identification of mycotoxins by UHPLC-QTOF MS in airborne fungi and fungi isolated from industrial paper and antique documents from the Archive of Bogotá. Environ. Res. 144, 130-138. http://dx.doi.org/10.1016/j.envre s.2015.10.031.

EC, 2001. Regulation (EC) no 999/2001 of the European Parliament and of the council of 22 May 2001 laying down rules for the prevention, control and eradication of certain transmissible spongiform encephalopathies. Official J. Eur. Union L147, 1-38.

EC, 2005. Regulation (EC) NO 396/2005 of the European Parliament and of the council of 23 February 2005 on maximum residue levels of pesticides in or on food and feed of plant and animal origin and amending Council Directive 91/414/EEC. Official J. Eur. Union. 
EC, 2009. Regulation (EC) No 1069/2009 of the European Parliament and of the council of 21 October 2009 laying down health rules as regards animal byproducts and derived products not intended for human consumption and repealing Regulation (EC) No 1774 (Animal by-products Regulation). Official J. Eur. Union L300, 1-33.

EC, 2013a. Commission regulation (EU) No 56/2013 of 16 January 2013 amending Annexes I and IV to Regulation (EC) No 999/2001 of the European Parliament and of the Council laying down rules for the prevention, control and eradication of certain transmissible spongiform encephalopathies. Official J. Eur. Union 21, 3-16.

EC, 2013b. Commission regulation (EU) No 212/2013 of 11 March 2013 replacing Annex I to regulation (EC) No 396/2005 of the European Parliament and of the council as regards additions and modifications with respect to the products covered by that Annex. Official J. Eur. Union.

EFSA, 2013. Scientific report of EFSA. The 2010 European Union report on pesticide residues in food. EFSA J. 11 (3130).

EFSA, 2015. Reporting Data on Pesticide Residues in Food and Feed According to Regulation (EC) No 396/2005 (2014 Data Collection) European Food Safety Authority http://www.efsa.europa.eu/ sites/default/_iles/scientific _output/fil (Accessed February 2016).

Friesen, E.N., Ikonomou, M.G., Higgs, D.A., Keng, P.A., Dubetz, C., 2008. Use of terrestrial based lipids in aquaculture feeds and the effects on flesh organohalogen and fatty acid concentrations in farmed Atlantic salmon. Environ. Sci.Technol. 42, 3519-3523. http://dx.doi.org/10.1021/es0714843. 
Golge, O., Kabak, B., 2015. Evaluation of QuEChERS sample preparation and liquid chromatography-triple-quadrupole mass spectrometry method for the determination of 109 pesticide residues in tomatoes. Food Chem. 176, 319322. http://dx.doi.org/10.1016/j.foodchem.2014.12.083.

Gómez-Pérez, M.L., Romero-González, R., Martínez Vidal, J.L., Garrido Frenich, A., 2015. Analysis of veterinary drug and pesticide residues in animal feed by high-resolution mass spectrometry: comparison between time-offlight and Orbitrap. Food Addit. Contam. - Part A Chem. Anal. control. Expo. Risk Assess. 32 http://dx.doi.org/10.1080/19440049. 2015.1023742.

Hatlen, B., Jakobsen, J.-V., Crampton, V., Alm, M., Langmyhr, E., Espe, M., Hevrøy, E.M., Torstensen, B.E., Liland, N., Waagbø, R., 2015. Growth, feed utilization and endocrine responses in Atlantic salmon (Salmo salar) fed diets added poultry by-product meal and blood meal in combination with poultry oil. Aquac. Nutr. 21, 214-725. http://dx.doi.org/10.1111/anu.12194.

Hernández, F., Ibáñez, M., Portolés, T., 2012. Comprehensive Environmental Mass Spectrometry. ILM Publications, Glendale (USA).

Hernández, F., Cervera, M.I., Portolés, T., Beltrán, J., Pitarch, E., 2013. The role of GC-MS/MS with triple quadrupole in pesticide residue analysis in food and the environment. Anal. Methods 5, 5875-5894. http://dx.doi.org/10.1039/ c3ay41104d.

Hernández, F., Ibáñez, M., Bade, R., Bijlsma, L., Sancho, J.V., 2014. Investigation of pharmaceuticals and illicit drugs in waters by liquid chromatography-high-resolution mass spectrometry. TrAC - Trends Anal. Chem. 63, 140-157. http:// dx.doi.org/10.1016/j.trac.2014.08.003. 
Hernández, F., Ibáñez, M., Botero-Coy, A.-M., Bade, R., Bustos-López, M.C., Rincón, J., Moncayo, A., Bijlsma, L., 2015a. LC-QTOF MS screening of more than 1,000 licit and illicit drugs and their metabolites in wastewater and surface waters from the area of Bogotá, Colombia. Anal. Bioanal. Chem. 407, 6405-6416. http:// dx.doi.org/10.1007/s00216-015-8796-x.

Hernández, F., Ibáñez, M., Portolés, T., Cervera, M.I., Sancho, J.V., López, F.J., 2015b. Advancing towards universal screening for organic pollutants in waters. J. Hazard. Mater. 282, 86-95. http://dx.doi.org/10.1016/j.jhazmat .2014 .08 .006 .

Kan, C.A., Meijer, G.A.L., 2007. The risk of contamination of food with toxic substances present in animal feed. Anim. Feed Sci. Technol 133, 81-108. http:// dx.doi.org/10.1016/j.anifeedsci.2006.08.005.

Krauss, M., Singer, H., Hollender, J., 2010. LC-high resolution MS in environmental analysis: from target screening to the identification of unknowns. Anal. Bioanal. Chem. 397, 943-951. http://dx.doi.org/10.1007 /s00216-010-3608-9.

Leeman, W.R., Van Den Berg, K.J., Houben, G.F., 2007. Transfer of chemicals from feed to animal products: the use of transfer factors in risk assessment. Food Addit. Contam. 24, 1-13. http://dx.doi.org/10.1080/ 02652030600815512 .

Lovell, R.A., Mcchesney, D.G., Price, W.D., 1996. Organohalogen and organophosphorus pesticides in mixed feed rations: findings from FDA's domestic surveillance during fiscal years 1989-1994. J. AOAC Int. 79, 544548. 
Lundebye, A.-K., Hove, H., Mage, A., Bohne, V.J., Hamre, K., 2010. Levels of synthetic antioxidants (ethoxyquin, butylated hydroxytoluene and butylated hydroxyanisole) in fish feed and commercially farmed fish. Food Addit. Contam. 27, 1652-1657.

Nácher-Mestre, J., Serrano, R., Benedito-Palos, L., Navarro, J.C., López, F.J., Pérez-Sánchez, J., 2009. Effects of fish oil replacement and re-feeding on the bioaccumulation of organochlorine compounds in gilthead sea bream (Sparus aurata L.) of market size. Chemosphere 76, 811-817. http://dx.doi.org/10.1016/j.chemosphere.2009.04.046.

Nácher-Mestre, J., Ibáñez, M., Serrano, R., Pérez-Sánchez, J., Hernández, F., 2013. Qualitative screening of undesirable compounds from feeds to fish by liquid chromatography coupled to mass spectrometry. J. Agric. Food Chem. 61, 2077-2087. http://dx.doi.org/10.1021/jf304478n.

Nácher-Mestre, J., Serrano, R., Portolés, T., Berntssen, M.H.G., PérezSánchez, J., Hernández, F., 2014. Screening of pesticides and polycyclic aromatic hydrocarbons in feeds and fish tissues by gas chromatography coupled to high-resolution mass spectrometry using atmospheric pressure chemical ionization. J. Agric. Food Chem. 62, 2165-2174. http://dx.doi.org/10.1021/jf405366n.

Pitarch, E., Cervera, M.I., Portolés, T., Ibáñez, M., Barreda, M., RenauPruñonosa, A., Morell, I., López, F., Albarrán, F., Hernández, F., 2016. Comprehensive monitoring of organic micro-pollutants in surface and groundwater in the surrounding of a solid-waste treatment plant of Castellón, Spain. Sci. Total Environ. 548-549, 211-220. http://dx.doi.org/10.1016/j. scitotenv.2015.12.166. 
Pizzutti, I.R., de Kok, A., Hiemstra, M., Wickert, C., Prestes, O.D., 2009. Method validation and comparison of acetonitrile and acetone extraction for the analysis of 169 pesticides in soya grain by liquid chromatography-tandem mass spectrometry. J. Chromatogr. A 1216, 4539-4552. http://dx.doi.org/10.1016/ j.chroma.2009.03.064.

Portolés, T., Sancho, J.V., Hernández, F., Newton, A., Hancock, P., 2010. Potential of atmospheric pressure chemical ionization source in GC-QTOF MS for pesticide residue analysis. J. Mass Spectrom. 45, 926-936. http://dx.doi.org/10.1002/ jms.1784.

Portolés, T., Mol, J.G.J., Sancho, J.V., Hernández, F., 2014. Use of electron ionization and atmospheric pressure chemical ionization in gas chromatography coupled to time-of-flight mass spectrometry for screening and identification of organic pollutants in waters. J. Chromatogr. A 1339, 145153. http://dx.doi.org/10.1016/j.chroma.2014.03.001.

Portolés, T., Garlito, B., Nácher-Mestre, J., Berntssen, M.H.G., PérezSánchez, J., 2017. Multi-class Determination of Undesirables in Aquaculture Samples by Gas Chromatography/tandem Mass Spectrometry with Atmospheric Pressure Chemical Ionization: a Novel Approach for Polycyclic Aromatic Hydrocarbons (Submitted).

Sanco, 2013. SANCO/12571/2013. Guidance Document on Analytical Quality Control and Validation Procedures for Pesticide Residues Analysis in Food and Feed.

Seiber, J., 2002. Environmental fate of pesticides. In: Wheeler, W.B. (Ed.), Pesticides in Agriculture and the Environment. New York. 
Sun, F., Chen, H.-S., 2008. Monitoring of pesticide chlorpyrifos residue in farmed fish: investigation of possible sources. Chemosphere 71, 1866-1869. http:// dx.doi.org/10.1016/j.chemosphere.2008.01.034.

Tacon, A.G.J., Metian, M., 2013. Fish Matters: importance of Aquatic foods in human nutrition and global food supply. Rev. Fish. Sci. 21, 22-38. http://dx.doi.org/ 10.1080/10641262.2012.753405.

Varó, I., Serrano, R., Pitarch, E., Amat, F., López, F.J., Navarro, J.C., 2002. Bioaccumulation of chlorpyrifos through an experimental food chain: study of protein HSP70 as biomarker of sublethal stress in fish. Arch. Environ. Contam. Toxicol. 42, 229-235. http://dx.doi.org/10.1007/s00244-001-0013-6.

White, N.D.G., Jayas, D.S., Demianyk, C.J., 1997. Degradation and biological impact of chlorpyrifos-methyl on stored wheat and pirimiphos-methyl on stored maize in Western Canada. J. Stored Prod. Res. 33, 125-135. http://dx.doi.org/10.1016/ S0022-474X(96)00049-5.

Ytrestøyl, T., Aas, T.S., Åsgård, T., 2015. Utilisation of feed resources in production of Atlantic salmon (Salmo salar) in Norway. Aquaculture 448, 365-374.http://dx.doi.org/10.1016/j.aquaculture.2015.06.023. 


\subsection{Artículo científico II}

Talanta 172 (2017) 109-119

Multi-class determination of undesirables in aquaculture samples by gas chromatography/tandem mass spectrometry with atmospheric pressure chemical ionization: A novel approach for polycyclic aromatic hydrocarbons

T. Portolés ${ }^{\mathrm{a}, \mathrm{s}}$, B. Garlito ${ }^{\mathrm{a}}$, Jaime Nácher-Mestre ${ }^{\mathrm{b}}$, M.H.G. Berntssen ${ }^{\mathrm{c}}$, J. Pérez-Sánchez ${ }^{\mathrm{b}}$

"Research Instưhute for Pesticides and Water, University Jaume I, 12071 Caste Í́n, Spain

'Institute of Aquaculture of Torre la Sal (LA TS, CSIC), 12595 Ribera de Cabanes, Castellbn, Spain

e National Instưute of Nutrǜion and Seafood Research, PO Box 2029 Nordnes, N-5817 Bergen, Nonway

A R T I C L E I N F O

\section{Keywords:}

Polycyclic aromatic hydrocarbons

Atmospheric pressure chemical ionization

Gas chromatography

Triple quadrupole

Aquaculture

Fish

Feed

\section{A B S T R A C T}

In this work, a method for the analysis of $24 \mathrm{PAHs}$ in 19 different matrices, including fish tissues, feeds and feed ingredients, has been developed using gas chromatography coupled to triple quadrupole tandem mass spectrometry with atmospheric pressure chemical ionization souroe (GC-APCI-MS/MS). The method is based on a modification of the unbuffered QuEChERS method, using freezing as an additional clean-up step and applying a 20-fold dilution factor to the final extract. The procedure was also tested for 15 pesticides and 7 polychlorinated biphenyl (PCB) congeners in order to widen the scope of the method.

The excellent sensitivity and selectivity provided by GC-APCI-MS/MS allowed the dilution of the sample extracts and quantification using calibration with standards in solvent for all the 19 matrices tested. The developed method was evaluated at 2,5 and $50 \mathrm{ng} \mathrm{g}^{-1}$ spiking levels. LOQs were $2 \mathrm{ng} \mathrm{g}^{-1}$ for most compounds, and LODs ranged from 0.5 to $2 \mathrm{ng} \mathrm{g}^{-1}$.

Analysis of real-world samples revealed the presence of naphthalene, fluorene, phenanthrene, fluoranthene and pyrene at concen tration levels ranging from 4.8 to $187 \mathrm{ng} \mathrm{g}^{-1}$. No PCBs, DDTs and pesticides were found in fillets from salmon and sea bream. 
Talanta 172 (2017) 109-119

\title{
Multi-class determination of undesirables in aquaculture samples by gas chromatography/tandem mass spectrometry with atmospheric pressure chemical ionization: A novel approach for polycyclic aromatic hydrocarbons
}

T. Portolés ${ }^{\mathrm{a}, *}$, B. Garlito ${ }^{\mathrm{a}}$, Jaime Nácher-Mestre ${ }^{\mathrm{b}}$, M.H.G. Berntssen ${ }^{\mathrm{c}}$, J. Pérez-Sánchez ${ }^{\mathrm{b}}$

${ }^{a}$ Research Institute for Pesticides and Water, University Jaume I, 12071 Castellón, Spain

${ }^{b}$ Institute of Aquaculture of Torre la Sal (IATS, CSIC), 12595 Ribera de Cabanes, Castellón, Spain

${ }^{c}$ National Institute of Nutrition and Seafood Research, PO Box 2029 Nordnes, N-5817 Bergen, Norway

\begin{abstract}
In this work, a method for the analysis of 24 PAHs in 19 different matrices, including fish tissues, feeds and feed ingredients, has been developed using gas chromatography coupled to triple quadrupole tandem mass spectrometry with atmospheric pressure chemical ionization source (GC-APCI-MS/MS). The method is based on a modification of the unbuffered QuEChERS method, using freezing as an additional clean-up step and applying a 20 -fold dilution factor to the final extract. The procedure was also tested for 15 pesticides and 7 polychlorinated biphenyl (PCB) congeners in order to widen the scope of the method.
\end{abstract}


The excellent sensitivity and selectivity provided by GC-APCI-MS/MS allowed the dilution of the sample extracts and quantification using calibration with standards in solvent for all the 19 matrices tested. The developed method was evaluated at 2, 5 and $50 \mathrm{ng} \cdot \mathrm{g}^{-1}$ spiking levels. LOQs were $2 \mathrm{ng} \cdot \mathrm{g}^{-1}$ for most compounds, and LODs ranged from 0.5 to $2 \mathrm{ng} \cdot \mathrm{g}^{-1}$.

Analysis of real-world samples revealed the presence of naphthalene, fluorene, phenanthrene, fluoranthene and pyrene at concentration levels ranging from 4.8 to $187 \mathrm{ng} \cdot \mathrm{g}^{-1}$. No PCBs, DDTs and pesticides were found in fillets from salmon and sea bream.

\section{Highlights}

- GC-APCI-MS/MS to determine 24 PAHs in 19 different matrices from aquaculture field. Elimination of matrix effect by a 20 -fold dilution factor of the final extract. Use of solvent calibration due to the excellent sensitivity and selectivity gained. Use of both $\mathrm{M}^{+\bullet}$ and $[\mathrm{M}+\mathrm{H}]^{+}$as an additional value to the selectivity. LOQs of $2 \mathrm{ng} \cdot \mathrm{g}^{-1}$ for most compounds, and LODs from 0.5 to $2 \mathrm{ng} \cdot \mathrm{g}^{-1}$.

\section{Keywords}

Polycyclic aromatic hydrocarbons, atmospheric pressure chemical ionization, gas chromatography, triple quadrupole, aquaculture, fish feed 


\section{Graphical abstract}
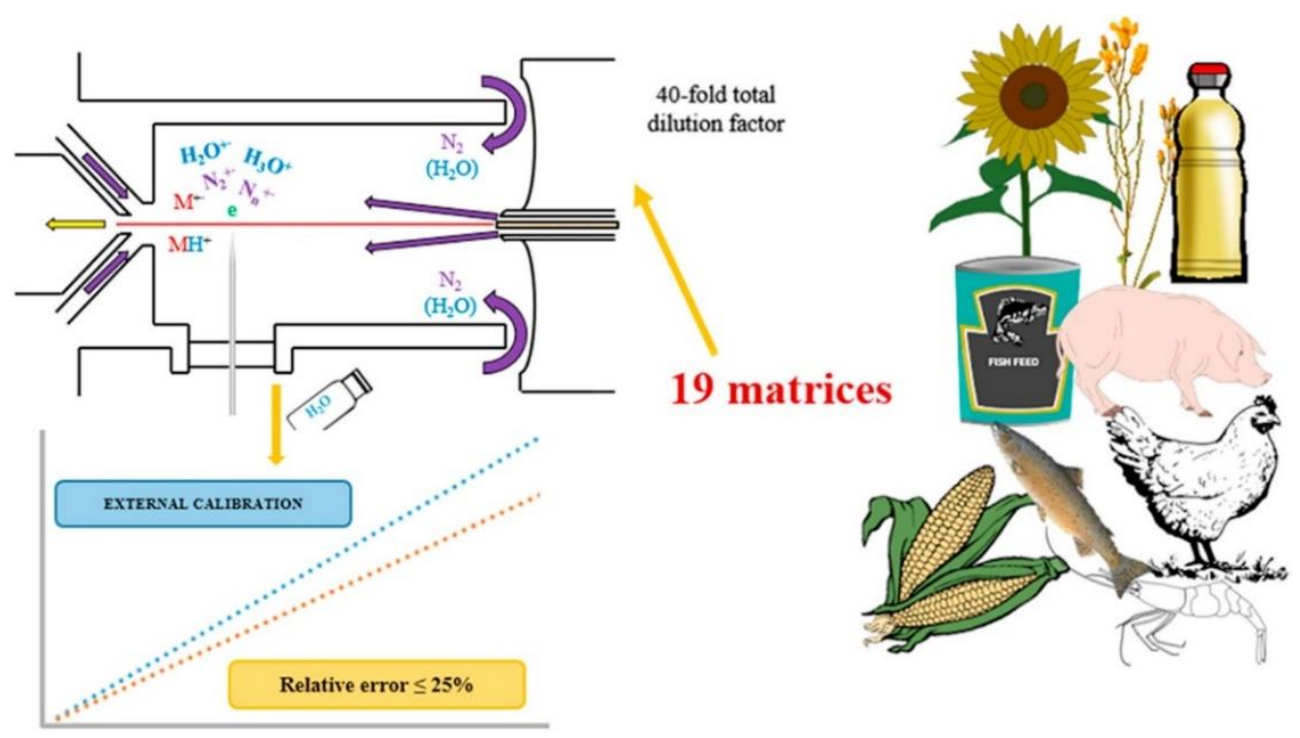


\section{Introduction}

Farming of carnivorous marine fish species such as Atlantic salmon (Salmo salar) and gilthead sea bream (Sparus aurata) has traditionally relied on the use of marine feed ingredients such as fish oil and meal in their formulated feeds [1-3]. Limited access to fish meal and fish oil for the rapidly growing aquaculture industry has led to a need to develop more sustainable aquafeeds that rely less on marine ingredients from feral fish stocks [4,5]. Vegetable oils and proteins are the main alternative to marine feed ingredients in aquafeeds $[2,5]$.

The development of new sustainable plant based feeds for marine fish farming introduces new challenges concerning contaminants that were previously not relevant when using traditional marine feed ingredients. Unrefined plant oils obtained from oilseeds such as soybeans, rapeseeds, olive seeds, and sunflower seeds are known to contain elevated levels of polyaromatic hydrocarbons (PAHs) [6-11]. Although fish oil also contains PAHs from environmental pollution [12], the use of plant oils causes increased PAH levels in plant-based salmon feeds compared to marine-based feeds [13]. In contrast, in a study on fish oil replacement in sea bream (Sparus aurata) feeds, plant oils did not have elevated PAH levels compared to fish oil, and it was concluded that feed PAH levels did not correlate with the amount of fish or plant oil used [14]. The genotoxic and carcinogenic "heavy" PAHs ( $>4-6$ rings), such as benzo[a]pyrene $(\mathrm{B}[\mathrm{a}] \mathrm{P})$, benzo[a]anthracene $(\mathrm{B}[\mathrm{a}] \mathrm{A})$, chrysene $(\mathrm{Chr})$, benzo[b]fluoranthene $(\mathrm{B}[\mathrm{b}] \mathrm{F})$, have received special attention with regards to food safety [15]. Studies related to plant oil PAH contamination, however, mainly focus on light (2-4 rings) PAHs such as fluoranthene, naphthalene, anthracene, phenanthrene, as they are most dominantly present 
in unrefined plant oils. These light PAHs are also on the US EPA (Environmental Protection Agency) list for environmental relevant PAHs but are mostly not carcinogenic and genotoxic $[10,16]$.

The European union has set an upper limit for 4 PAHs $(\mathrm{B}[\mathrm{a}] \mathrm{P}+\mathrm{B}[\mathrm{a}] \mathrm{A}+\mathrm{Chr}$ $+\mathrm{B}[\mathrm{b}] \mathrm{F})$ in food products to protect the consumer safety [15]. No upper limits for PAH in feed ingredients or animal feeds currently exist. The PAH levels of raw ingredients for feeds for farmed terrestrial animals such as cow, chicken, and pig have been reported in only few studies [11] and little is known on PAH levels in feeds for farmed fin fish species [17,18], especially for feed ingredients used in novel plant based fish feed $[13,14,19]$.

Traditionally, the determination of PAHs in solid fatty matrices have involved time-consuming extractions prior to GC-MS with electron ionization (EI) analysis [20]. However, the sensitivity restrictions of the GC-EI-MS(/MS) systems [21,22] in addition to the inherent matrix effects make preconcentration and time consuming clean-up steps, as gel permeation chromatography [23] or solid phase extraction [19,24], necessary. Recently, some methodologies have applied the QuEChERS procedure in aquaculture samples $[25,26]$, reducing notably the time and cost of sample treatment. However, despite all efforts to minimize the presence of interferences, the still remaining matrix effects make necessary to use matrix-matched calibration for quantification purposes [22]. In the last years, the application of atmospheric pressure chemical ionization (APCI) source in combination with last generation triple quadrupole instruments has made possible to notably increase sensitivity and selectivity of the determination of organic contaminants in food safety, environment and doping control fields [27-30] in selected reaction monitoring (SRM) based methods. The improved 
performance of GC-APCI-MS/MS is more than welcome in the aquaculture field, where the analysis of a wide diversity of "difficult" matrices (oils, plant ingredients, marine ingredients, terrestrial animal ingredients, fish, etc.) with this technique can be simplified by reducing the matrix content in the final extract by simple dilution which minimizes the matrix effect and avoids the need of using matrix-matched calibrations.

In this work, we explore the potential of the new GC-APCI-MS/MS technique for quantification and confirmation of PAHs, together with some selected pesticides and PCBs, in very different sample matrices from aquaculture field. Sensitivity of this new technique has been exploited in order to avoid the timeconsuming and expensive purification steps commonly used in these complex matrices and with the aim of obtaining a cheap and efficient sample treatment. The developed methodology has been applied to the quantification of compounds that were previously found in wide-scope screening of aquaculture samples by combined use of GC \& LC-QTOF MS. Up to our knowledge this is the first application of GC-APCI-MS/MS with triple quadrupole to the analysis of PAHs in samples from aquaculture field.

\section{Experimental}

\subsection{Reagents}

Benzo[j]fluoranthene $(\mathrm{B}[\mathrm{j}] \mathrm{F})$, 5-methylchrysene (5-MC), benzo[c]fluorene $(\mathrm{B}[\mathrm{c}] \mathrm{F}), \quad$ dibenzo[a,e $]$ pyrene $(\mathrm{D}[\mathrm{a}, \mathrm{e}] \mathrm{P}), \quad$ dibenzo[ $a, h]$ pyrene $\quad(\mathrm{D}[\mathrm{a}, \mathrm{h}] \mathrm{P})$, dibenzo[a,i]pyrene $\quad(\mathrm{D}[\mathrm{a}, \mathrm{i}] \mathrm{P}), \quad$ dibenzo[a,l]pyrene $\quad(\mathrm{D}[\mathrm{a}, 1] \mathrm{P}), \quad$ and cyclopenta[c,d]pyrene $(\mathrm{C}[\mathrm{c}, \mathrm{d}] \mathrm{P})$ individual standard solutions at $10 \mathrm{mg} \cdot \mathrm{L}^{-1}$ 
(100 mg $\cdot \mathrm{L}^{-1}$ for $\left.\mathrm{C}[\mathrm{c}, \mathrm{d}] \mathrm{P}\right)$, PAH MIX 9 containing $16 \mathrm{PAHs}\left(10 \mathrm{mg} \cdot \mathrm{L}^{-1}\right.$ in cyclohexane) and PCB mix $3\left(100 \mathrm{ng} \cdot \mu \mathrm{L}^{-1}\right.$ in isooctane) were purchased from Dr. Ehrenstorfer (Augsburg, Germany). Reference standards diphenylamine, ethoxyquin, p,p'-DDD, p,p'- DDT, tebuconazole, azoxystrobin, fluazinam and imazalil supplied by Dr. Ehrenstorfer GmbH (Augsburg, Germany); boscalid and malathion by Riedel-de Haën (Seelze, Germany); ethoxyquin dimer by Synthetica AS (Oslo, Norway) and hexachlorobenzene (HCB), pirimiphosmethyl and chlopyrifos-methyl by Sigma-Aldrich (St Louis, MO, USA) with a purity 97-99.9\% were used for standard preparation (see structures for all the compounds in Table S1). Stock standard solutions (around $500 \mathrm{mg} \cdot \mathrm{L}^{-1}$ ) were prepared in acetone. Two mixtures of pesticide standards (individual concentration of each pesticide around $50 \mathrm{mg} \cdot \mathrm{L}^{-1}$ ) were prepared by dilution of stock individual solutions in acetone. Working standard solutions containing all compounds were prepared by dilution of mixtures with acetone (for sample fortification in GC) and hexane (GC injection). Stock standard solutions and working solutions were stored in a freezer at $-20{ }^{\circ} \mathrm{C}$.

Stable isotopic labeled internal standards (SIL-IS) PCB $153-{ }^{13} \mathrm{C}_{12}$ and PAH surrogate cocktail containing acenaphthylene- $\mathrm{D}_{8}, \mathrm{~B}[\mathrm{a}] \mathrm{P}-\mathrm{D}_{12}, \mathrm{~B}(\mathrm{~g}, \mathrm{~h}, \mathrm{i}) \mathrm{Pe}-\mathrm{D}_{12}$, fluoranthene- $\mathrm{D}_{10}$, naphthalene- $\mathrm{D}_{8}$, phenanthrene- $\mathrm{D}_{10}$ and pyrene- $\mathrm{D}_{10}$ were purchased from Cambridge Isotope Laboratories (Andover, MA, USA). Hexachlorobenzene- $-{ }^{13} \mathrm{C}_{6}$, tebuconazole- $\mathrm{D}_{6}$ and $\mathrm{p}, \mathrm{p}^{\prime}-\mathrm{DDE}-\mathrm{D}_{8}$ were also purchased from Dr. Ehrenstorfer.

HPLC-supragradient acetonitrile, acetone (pesticide residue analysis quality) and n-hexane (ultra-trace quality) were purchased from Scharlab (Barcelona, Spain). Anhydrous magnesium sulfate (extra pure) and anhydrous sodium acetate (reagent grade) were purchased from Scharlab. The QuEChERS 
commercial clean-up kits were purchased from Teknokroma (Barcelona, Spain). Each kit contains $50 \mathrm{mg}$ of primary-secondary amine (PSA), $150 \mathrm{mg}$ of anhydrous magnesium sulfate, and $50 \mathrm{mg}$ of $\mathrm{C}_{18}$, in $2 \mathrm{~mL}$ microcentrifuge tubes for d-SPE.

Table S1. Structures for all the compounds

Acenaphthene


Table S1. (continuation)

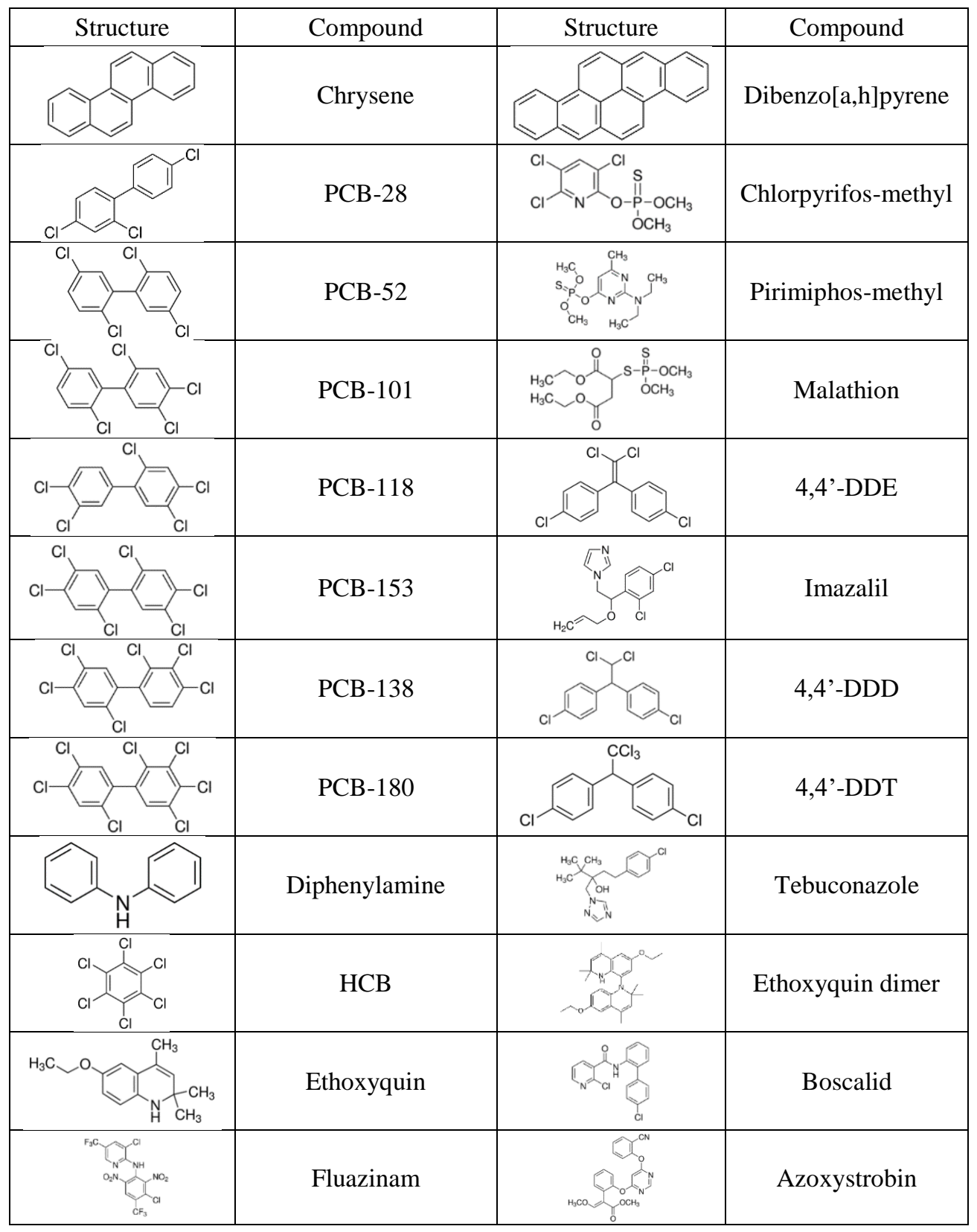




\subsection{Samples}

The sample material has been described before in detail [31]. A total of 76 samples (from 19 different matrices) were studied in this work. The list contains ingredients from different origin (plant, terrestrial animals and marine), and also feeds based on these ingredients (PAPs not included), as well as fillets of Atlantic salmon and gilthead sea bream reared on these feeds. Fish individuals were fed for, respectively, 7 and 18 months, and fillet samples were taken for analysis at the end of the exposure trial and, additionally, for sea bream at 8 months (commercial size). The same feed compositions were provided throughout the feeding trial. The quantification was performed on feed ingredients, feeds produced from the same feed ingredients, and fish fillets of fish fed on these feeds. The feed samples were analyzed at the beginning of the trial (additionally after 8 months for sea bream) and no stability assessment was made by analyzing the feed during storage (below $7^{\circ} \mathrm{C}$ for salmon and sea bream feeds).

Commercially available plant and marine feed ingredients were provided by Biomar (Tech Center, Brande, Denmark) feed producer and processed animal proteins (PAPs) from non-ruminants were provided by the European Fat Processors and Renderers Association (EFPRA). The ingredients selected represent the novelties in fish feed compositions to reduce the inclusion of fish derivatives. Fish feeds for feeding trials were based on plant feed ingredients, and not PAPs, as higher levels of PAHs were found in plant feed ingredients. The feeds were produced by Biomar under commercial aquafeed production techniques based on high-temperature extrusion processes, which potentially could affect pesticide residue levels. 


\subsection{Sample treatment}

Samples were thawed at room temperature and $1 \mathrm{~g}$ was accurately weighed and transferred to $15 \mathrm{~mL}$ falcon tubes and spiked with $0.2 \mathrm{~mL}$ of SIL-IS solution of $1 \mu \mathrm{g} \cdot \mathrm{mL}^{-1}$. After $30 \mathrm{~min}, 2 \mathrm{~mL}$ of acetonitrile were added and the tube was vigorously shaken by vortex for $30 \mathrm{~s}$. Then, $0.8 \mathrm{~g}$ of $\mathrm{MgSO}_{4}$ were added and the tube was immediately shaken for $30 \mathrm{~s}$. Subsequently, the tube was centrifuged at $1893 \mathrm{rcf} \cdot \mathrm{g}$ for $5 \mathrm{~min}$ and the upper layer of the extract was transferred to a $2 \mathrm{~mL}$ eppendorf tube and stored for at least two hours in a freezer to precipitate proteins and fix lipids to the tube walls (freezing cleanup). Then, a QuEChERS clean-up step was carried out prior injection in the GC-system [25]. Briefly, $1 \mathrm{~mL}$ of the extract was carefully transferred to the cleanup QuEChERS vial (50 mg of PSA $+150 \mathrm{mg}$ of $\mathrm{MgSO}_{4}+50 \mathrm{mg}$ of $\mathrm{C}_{18}$ ), and it was vigorously shaken for $30 \mathrm{~s}$ and centrifuged at $12,557 \mathrm{rcf} \cdot \mathrm{g}$ for

$5 \mathrm{~min}$. Then, $50 \mu \mathrm{L}$ of the final acetonitrile extract was diluted with $300 \mu \mathrm{L}$ of acetone and $650 \mu \mathrm{L}$ of hexane in order to make the solution miscible (20-fold dilution factor).

\subsection{Instrumentation}

\subsubsection{GC-APCI-MS/MS}

Data were acquired using a GC system (Agilent 7890A, Palo Alto, CA, USA) equipped with an autosampler (Agilent 7693) and coupled to a triple quadrupole (QqQ) mass spectrometer (Xevo TQ-S, Waters Corporation, Manchester, UK), operating in positive APCI mode. The GC separation was performed using a fused silica DB-17MS (50\% phenyl-methylpolysiloxane) 
capillary column with a length of $30 \mathrm{~m} \times 0.25 \mathrm{~mm}$ i.d. and a film thickness of $0.25 \mu \mathrm{m}$ with a $1 \mathrm{~m} \times 0.25 \mathrm{~mm}$ i.d deactivated post-column (J \& W Scientific, Folson, CA, USA). The oven temperature was programmed as follows: $70^{\circ} \mathrm{C}(1 \mathrm{~min}) ; 20^{\circ} \mathrm{C} \cdot \mathrm{min}^{-1}$ to $230^{\circ} \mathrm{C} ; 5^{\circ} \mathrm{C} \cdot \mathrm{min}^{-1}$ to $320^{\circ} \mathrm{C}(6 \mathrm{~min})$. The injector was operated in pulsed splitless mode (50 psi), injecting $1 \mu \mathrm{L}$ at $280^{\circ} \mathrm{C}$. Helium was used as carrier gas at a ramped flow mode programmed as follows: $2 \mathrm{~mL} \cdot \mathrm{min}^{-1}\left(23 \mathrm{~min}\right.$ ); a ramp of $4 \mathrm{~mL} \cdot \mathrm{min}^{-1}$ to 6 $\mathrm{mL} \cdot \mathrm{min}^{-1}(9 \mathrm{~min})$. In the SRM method, automatic dwell time (values ranging from 3 to $63 \mathrm{~ms}$ ) was applied in order to obtain 15 points per peak. The interface and source temperatures were set to $320^{\circ} \mathrm{C}$ and $150^{\circ} \mathrm{C}$ respectively using $\mathrm{N}_{2}$ as auxiliary gas at $275 \mathrm{~L} \cdot \mathrm{h}^{-1}$, as make-up gas at 300 $\mathrm{mL} \cdot \mathrm{min}^{-1}$ and as cone gas at $200 \mathrm{~L} \cdot \mathrm{h}^{-1}$. The APCI corona discharge pin was operated at $1.6 \mu \mathrm{A}$. The ionization process occurred within an enclosed ion volume, which enabled control over the protonation/charge transfer processes. In order to work under proton transfer conditions, an uncapped vial containing $1.25 \mathrm{~mL}$ of water was placed in a designed holder into the APCI source door to enhance protonation. Targetlynx (a module of MassLynx) was used to handle and process the acquired data.

\subsection{Study of matrix effects}

Nine out of nineteen different matrices (fish fillets, feed and PAPs) were selected for the study of matrix effects and different dilution factors were tested (crude extract, 5-fold, 10-fold and 20-fold dilution). To this aim, matrixmatched calibrations were prepared for each sample matrix by taking between 25 and $500 \mu \mathrm{L}$ of the "blank" sample extract (for crude extract, $500 \mu \mathrm{L}$ were 
evaporated to dryness) and adding $50 \mu \mathrm{L}\left(125 \mu \mathrm{L}\right.$ for the $25 \mathrm{ng} \cdot \mathrm{mL}^{-1}$ level) of the corresponding standard in hexane (between 10 and $100 \mathrm{ng} \cdot \mathrm{mL}^{-1}$ ), resulting in final analyte concentrations between 1 and $25 \mathrm{ng} \cdot \mathrm{mL}^{-1}$. The final volume of each calibration point was $500 \mu \mathrm{L}$ in all cases (30\% acetone, $5 \%$ acetonitrile and $65 \%$ hexane). Matrix effect was evaluated by comparing the calibration graphs obtained with standards in solvent and in matrix (at the different dilution factors) [32]. The accepted relative error between the slopes of calibration in solvent and matrix-matched calibration was $\pm 25 \%$. Once the optimum dilution factor was selected, the absence of matrix effect was also tested for the remaining 10 matrices.

\subsection{Validation and recovery experiments}

Eleven SIL-IS were added at the initial stage of the procedure as quality control (surrogates) in order to correct for possible losses during the overall procedure and instrumental deviations. Linearity of relative response of analytes was established by analyzing standard solutions injected in triplicate in the range of $0.01-25 \mathrm{ng} \cdot \mathrm{mL}^{-1}$ for all compounds except for $\mathrm{C}[c, d] \mathrm{P}(0.005-$ $\left.12.5 \mathrm{ng} \cdot \mathrm{mL}^{-1}\right)$. Linearity was assumed when the correlation coefficient $\left(\mathrm{R}^{2}\right)$ was higher than 0.99 with residuals lower than $30 \%$.

A full validation of the method was carried out for two sample matrices, salmon and sea bream fillets. Accuracy (estimated by means of recovery experiments) was evaluated by analyzing six replicates spiked at $2 \mathrm{ng} \cdot \mathrm{g}^{-1}$ (1 $\mathrm{ng} \cdot \mathrm{g}^{-1}$ for $\left.\mathrm{C}[c, d] \mathrm{P}\right)$ and $50 \mathrm{ng} \cdot \mathrm{g}^{-1}\left(25 \mathrm{ng} \cdot \mathrm{g}^{-1}\right.$ for $\left.\mathrm{C}[c, d] \mathrm{P}\right)$ for the two matrices tested. Precision was expressed as repeatability in terms of relative standard deviation (RSD, \%) $(n=6)$ calculated for each fortification level. The limit of 
quantification (LOQ) objective, for salmon and sea bream fillets, was defined as the lowest concentration level validated following SANTE/11945/2015 guide criteria [33] (recovery 70-120\% and RSDs below 20\%). For those compounds that could not be validated due to the high concentration in the "blank" sample a statistically calculated LOQ was estimated as the analyte concentration that produced a peak signal of ten times the background noise in the chromatogram at the lowest fortification level tested for each compound. The limit of detection (LOD) was estimated for all compounds considering a signal-to-noise $(\mathrm{S} / \mathrm{N})$ ratio of three.

The methodology was validated for the remaining 17 sample matrices by analysis of quality control (QC) samples, i.e. "blank" samples spiked at 5 and $50 \mathrm{ng} \cdot \mathrm{g}^{-1}$ injected in each batch. A total of 48 QCs prepared from 24 "blank" samples (corresponding to 17 different matrices) were analyzed. Recoveries between $60 \%$ and $140 \%$ for each individual sample were considered satisfactory following the acceptance criteria for routine recoveries according to SANTE/11945/ 2015 guide criteria [33].

The selectivity of the method was assured by choosing selective SRM transitions using $\mathrm{M}^{+\bullet}$ or $[\mathrm{M}+\mathrm{H}]^{+}$as precursor ion, when possible. Specificity was evaluated by verification of the absence of interfering peaks at the retention time of each compound in blank samples for the acquired SRM transitions.

The $\mathrm{q}_{\mathrm{i}} / \mathrm{Q}$ ratio, defined as the ratio between the intensity of the confirmation ion $\left(\mathrm{q}_{\mathrm{i}}\right)$ and the quantification ion $(\mathrm{Q})$, was used to confirm peak identity in real and spiked samples. The experimental qi/ Q value for each compound was calculated as the mean value obtained from three standard solutions injected 
in triplicate (RSD below 15\% in all cases) Confirmation of analytes detected in samples was considered positive when the $\mathrm{q}_{\mathrm{i}} / \mathrm{Q}$ ratio was within acceptable tolerances (30\% of the experimental $\mathrm{q}_{\mathrm{i}} / \mathrm{Q}$ value calculated from standards) according to SANTE/11945/2015 guide criteria [33].

\section{Results and discussion}

\subsection{Ionization and fragmentation behavior of PAHs in GC-APCI}

In this work, the ionization behavior of the APCI interface was tested using PAH standards in solvent. Two mechanisms of ionization were simultaneously observed: i) charge transfer in which the nitrogen plasma created by the corona discharge needle promotes the formation of $\mathrm{M}^{+\bullet}$, and ii) proton transfer, where the presence of water vapor traces in the source favors the formation of the $[\mathrm{M}+\mathrm{H}]^{+}$ion.

The PAHs studied showed a mixture of two ions, $\mathbf{M}^{+\bullet}$ and $[\mathrm{M}+\mathrm{H}]^{+}$, as base peak of the spectrum. In the case of acenaphthene, fluorene, phenanthrene, anthracene, fluoranthene, pyrene, $\mathrm{B}[c] \mathrm{F}$ and $\mathrm{C}[\mathrm{c}, \mathrm{d}] \mathrm{P}$, the $[\mathrm{M}+\mathrm{H}]^{+}$intensity was slightly higher than $\mathrm{M}^{+\bullet}$ (among 1.2 and 1.5 times higher). In contrast, the intensity of $\mathrm{M}^{+\bullet}$ was around 1.1 and 1.2 times higher than $[\mathrm{M}+\mathrm{H}]^{+}$for naphthalene, I[1,2,3-cd]P, B[g,h,i]Pe, D[a,h]A, D[a,h]P, D[a,e]P, D[a,i]P and $\mathrm{D}[\mathrm{a}, 1] \mathrm{P}$. For the rest of PAHs, the abundance of $\mathrm{M}^{+\bullet}$ and $[\mathrm{M}+\mathrm{H}]^{+}$was similar. Fig. 1 (up) shows the APCI spectrum of $\mathrm{D}[\mathrm{a}, 1] \mathrm{P}$ where $\mathrm{M}^{+\bullet}$ and $[\mathrm{M}+\mathrm{H}]^{+}$can be observed as base peak of the spectrum. After that, the fragmentation of the PAHs in the collision cell was studied. $\mathrm{M}^{+\bullet}$ and $[\mathrm{M}+\mathrm{H}]^{+}$were selected as precursor ions for all PAHs. Fragmentation was performed at collision 
energies between $10-60 \mathrm{eV}$. The losses of $\mathrm{H}^{\bullet}$ and $\mathrm{H}_{2}$ from both $\mathrm{M}^{+\bullet}$ and $[\mathrm{M}+\mathrm{H}]^{+}$were the most abundant and common to all PAHs studied. Losses as $\mathrm{CH}_{3}{ }^{\circ}$ or $\mathrm{C}_{2} \mathrm{H}_{2}$ among others were also commonly observed. The use of water as modifier favored the formation of the $[\mathrm{M}+\mathrm{H}]^{+}$and the $\mathrm{M}^{+\bullet}$ decreased in all cases (see Fig. 1, down). However, $\mathrm{M}^{+\bullet}$ still appeared in the spectra in a percentage among 35-80\%, depending on the $\mathrm{PAH}$.

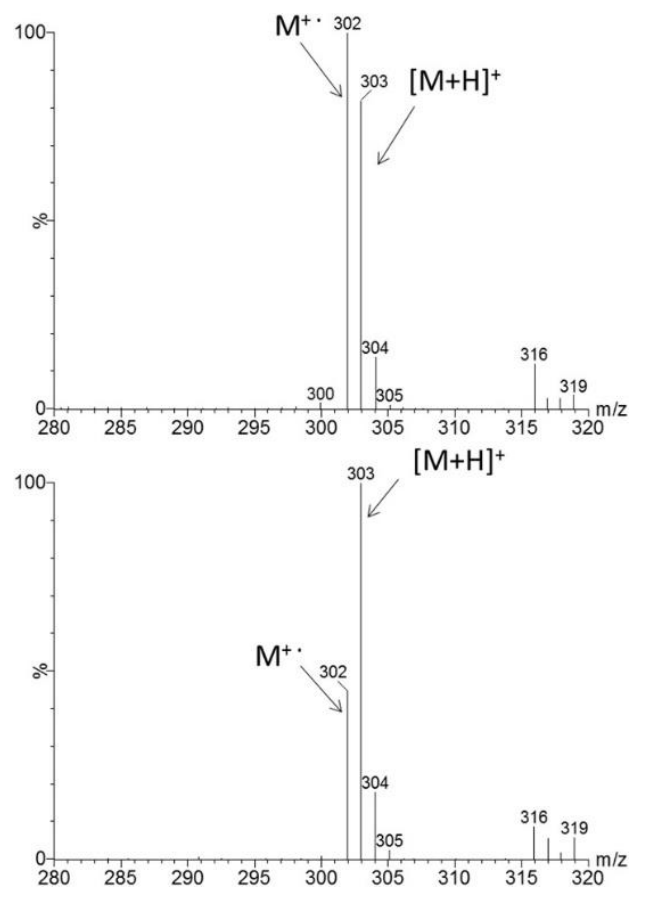

Fig. 1. APCI mass spectra of D[a, l]P under charge transfer conditions (up) and under proton transfer conditions with water as modifier (down).

\subsection{Sensitivity and repeatability. Effect of different modifiers.}

Once the SRM transitions were optimized, the sensitivity and repeatability of the GC-MS/MS signals were evaluated for all the transitions selected (those coming from $\mathrm{M}^{+\bullet}$ as well as from $[\mathrm{M}+\mathrm{H}]^{+}$). As explained above, both $[\mathrm{M}+\mathrm{H}]^{+}$ 
and $\mathrm{M}^{+\bullet}$ were observed in the APCI spectra of all PAHs even under "dry" conditions. Thus, we investigated the effect of different modifiers in order to promote the formation of the protonated molecules and to increase the sensitivity of SRM transitions coming from $[\mathrm{M}+\mathrm{H}]^{+}$. Water, $0.5 \%$ formic acid, methanol and isopropanol were added separately in an uncapped vial, which was located within a specially designed holder placed in the source door. The sensitivity and repeatability of the GC-MS/MS signals for PAHs were evaluated under the different conditions (with and without the use of modifiers).

As can be seen in Fig. 2 (up), under charge transfer conditions (without adding a modifier), SRM transitions coming from $\mathrm{M}^{+\bullet}$ were more sensitive than those coming from $[\mathrm{M}+\mathrm{H}]^{+}$for acenaphthene, fluorene, $\mathrm{B}(\mathrm{c}) \mathrm{F}, \mathrm{C}[\mathrm{c}, \mathrm{d}] \mathrm{P}$, chrysene, 5-MC, $\mathrm{B}(\mathrm{b}) \mathrm{F}$ and $\mathrm{B}(\mathrm{j}) \mathrm{F}$ (among 2 and 4 times higher). In contrast, the sensitivity of SRM transitions coming from $[\mathrm{M}+\mathrm{H}]^{+}$was higher than $\mathrm{M}^{+\bullet}$ (among 3 and 14 times) for naphthalene, acenaphthylene, phenanthrene, anthracene, fluoranthene, pyrene and B[g,h,i]Pe. For the rest of PAHs, they were mostly similar. When adding water as modifier, the sensitivity of transitions coming from the $\mathrm{M}^{+\bullet}$ decreased between 1.5 and 3 times for all compounds, except for $\mathrm{D}[\mathrm{a}, \mathrm{h}] \mathrm{A}$ which was rather similar; and consequently, the intensity for $[\mathrm{M}+\mathrm{H}]^{+}$transitions improved 1.5-2 times for high molecular weight PAHs (HMW-PAHs, with four or more aromatic rings).

When adding $\mathrm{HCOOH} 0.5 \%$, the sensitivity of $[\mathrm{M}+\mathrm{H}]^{+}$transitions remained almost the same as with only water (Fig. 2 (down)). Similar results were obtained using $\mathrm{MeOH}$ as modifier, except for some compounds, such as naphthalene, fluorene, phenanthrene, fluoranthene, chrysene and $\mathrm{B}(\mathrm{b}) \mathrm{F}$, among others, whose responses decreased considerably. Regarding 
isopropanol, its use was not beneficial because sensitivity extremely decreased for most of the compounds. Thus, the modifiers $\mathrm{MeOH}$ and isopropanol were discarded for further optimization.

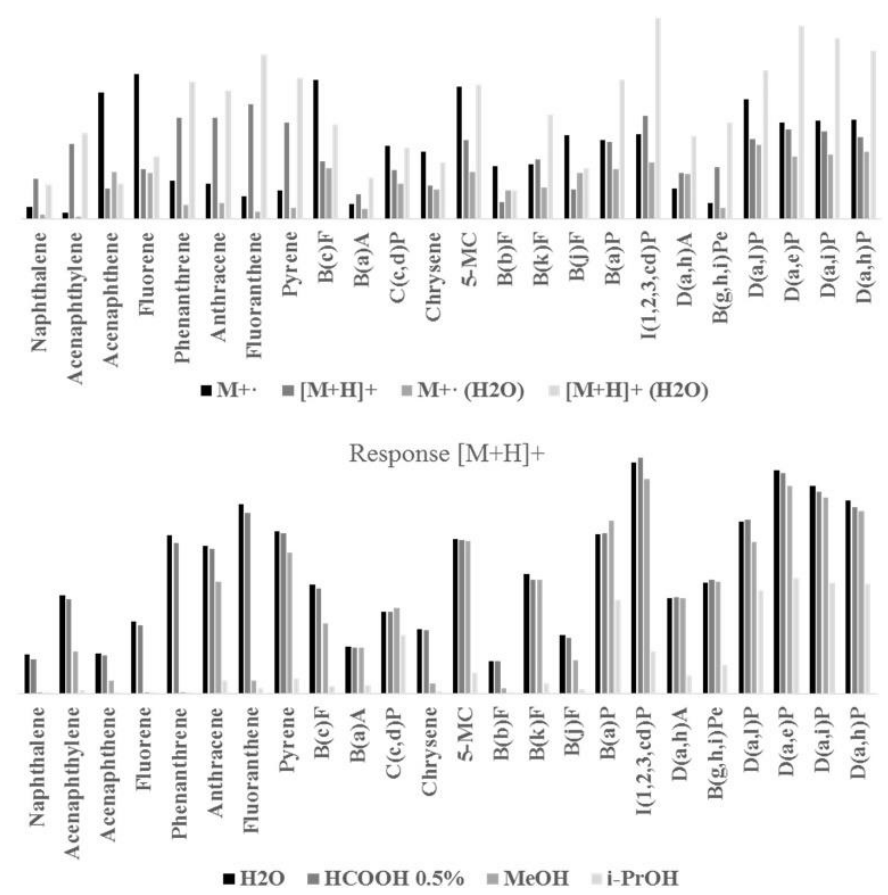

Fig. 2. Absolute sensitivity of SRM transitions coming from $\mathrm{M}^{+\cdot}$ and $[\mathrm{M}+\mathrm{H}]^{+}$ for PAHs under charge transfer and proton transfer (with water) ionization conditions (up); absolute sensitivity of SRM transitions coming from $[\mathrm{M}+\mathrm{H}]^{+}$ under proton transfer conditions using different modifiers (bottom).

Once these modifiers were discarded, the repeatability of the response $(n=10$ at $10 \mathrm{ng} \cdot \mathrm{mL}^{-1}$ ) was also evaluated under the remaining working conditions (without water, with water and with $\mathrm{HCOOH} 0.5 \%$ ) (Fig. S1). Our data showed a slightly poorer repeatability for $\mathrm{M}^{+\bullet}$ and $[\mathrm{M}+\mathrm{H}]^{+}$transitions working under dry conditions (relative standard deviations, RSD, between 20-30\% for most compounds) being a bit better (RSD 10-17\%) for fluoranthene, pyrene 
and low molecular weight PAHs (LMW-PAHs, 2-3 aromatic rings). This parameter was improved under wet conditions using water as modifier for $\mathrm{M}^{+\bullet}$ (RSD 7-20\%) and specially for $[\mathrm{M}+\mathrm{H}]^{+}$transitions (RSD 2-8\%), but dramatically get worst when adding $\mathrm{HCOOH} 0.5 \%$, especially for $\mathrm{M}+$. transitions (RSD 14-39\%).

Overall, the use of water as modifier was selected for further experiments, selecting the transitions from $[\mathrm{M}+\mathrm{H}]^{+}$for most of PAHs. In some particular cases, the most sensitive transitions using $\mathrm{M}^{+\bullet}$ as precursor ion were used for confirmation purposes (except for $\mathrm{b}[j] \mathrm{F}$ which was used for quantification) (Table 1).

In a later stage, the optimum conditions selected for PAHs were tested for the PCBs and pesticides in order to widen the applicability of the methodology to other relevant pollutants included in the method. In previous works, it was reported that sensitivity for halogenated hydrocarbons without any other heteroatoms, e.g. PCBs and many organochlorine pesticides (such as hexachlorobutadiene, pentachlorobenzene, hexachlorobenzene, $\mathrm{HCHs}$, DDTs, trans-chlordane, mirex) was negatively affected by the introduction of water in the source [34,35]. Despite this fact, the sensitivity and repeatability of PCBs, p,p'-DDT, p,p'-DDD, p,p'-DDE and HCB was still enough to reach the maximum residue level regulated. Regarding the other pesticides included in the method, ionization efficiency was favored under proton-transfer conditions, i.e. selecting $[\mathrm{M}+\mathrm{H}]^{+}$as precursor ion, except for ethoxyquin and ethoxyquin dimer that were scarcely affected. 


\section{RSD (\%): no modifier}
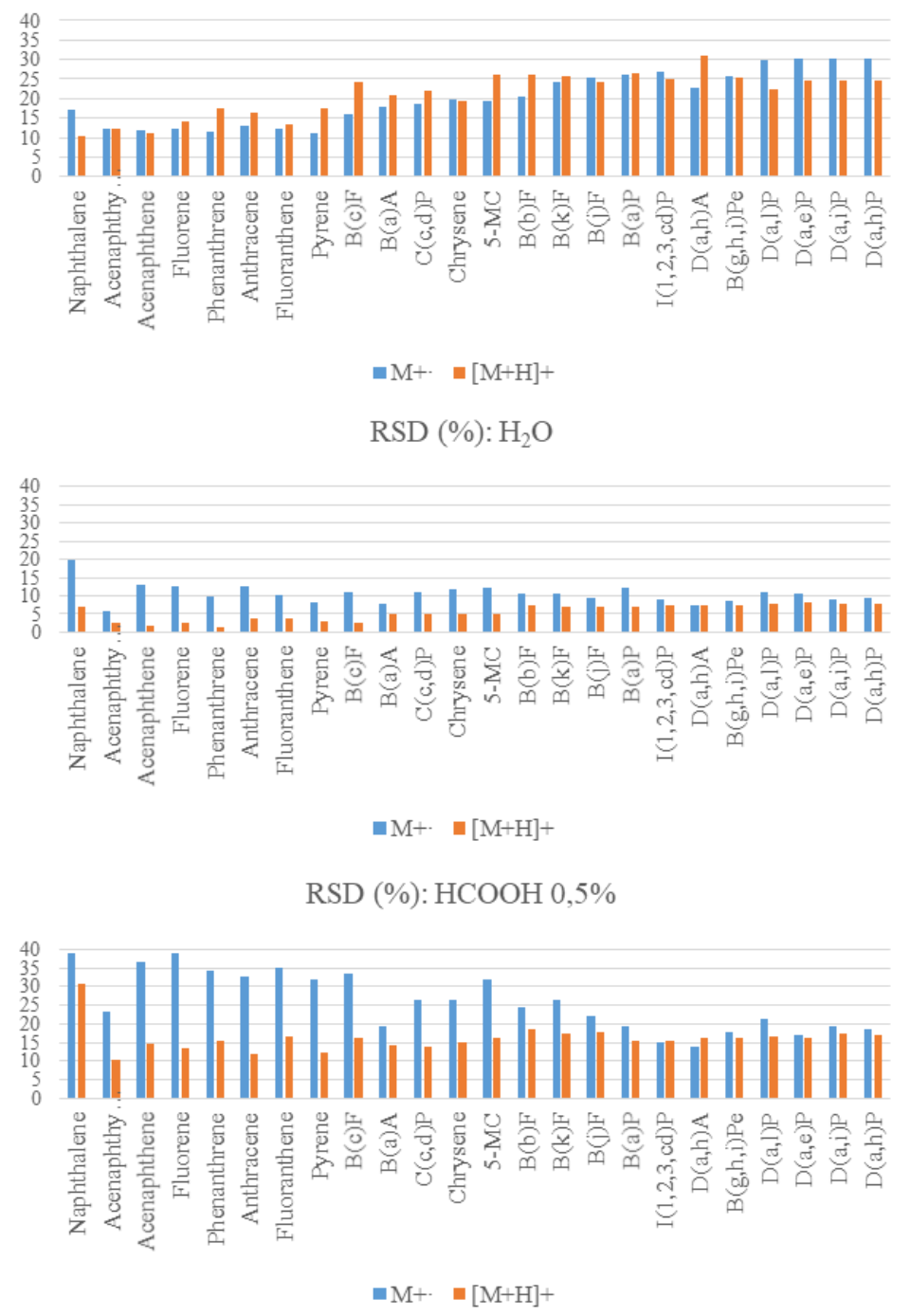

Figure S1. Repeatability of the response (n=10 at $10 \mathrm{ng} / \mathrm{mL}$ ) evaluated under the following working conditions (without water, with water and with $\mathrm{HCOOH} 0.5 \%$ ). 
Table 1. Experimental conditions of the optimized GC-APCI-MS/MS method using water as modifier. Quantifier (Q) and qualifier (q) transitions.

\begin{tabular}{|c|c|c|c|c|c|c|}
\hline Rt (min) & Compound & Internal Standard & Precursor ion & Product ion & $\mathrm{CE}(\mathrm{EV})$ & q/Q ratio \\
\hline 5.53 & Naphthalene- $\mathrm{D}_{8}$ & \multirow{6}{*}{ Naphthalene- $\mathrm{D}_{8}$} & 136 & 134.1 & 30 & Q \\
\hline \multirow[t]{5}{*}{5.55} & \multirow[t]{5}{*}{ Naphthalene } & & \multirow[t]{4}{*}{129} & 128.1 & 20 & $\mathrm{Q}$ \\
\hline & & & & 126.8 & 20 & 0.273 \\
\hline & & & & 103 & 20 & 0.011 \\
\hline & & & & 79 & 20 & 0.002 \\
\hline & & & 128 & 102.1 & 20 & 0.063 \\
\hline 7.65 & Acenaphthylene- $\mathrm{D}_{8}$ & \multirow{5}{*}{$\begin{array}{l}\text { Acenaphthylene- } \\
D_{8}\end{array}$} & 160 & 158.3 & 30 & Q \\
\hline \multirow[t]{4}{*}{7.66} & \multirow[t]{4}{*}{ Acenaphthylene } & & 153 & 152 & 20 & Q \\
\hline & & & & 150.1 & 30 & 0.010 \\
\hline & & & & 125.9 & 30 & 0.018 \\
\hline & & & 152 & 126.1 & 30 & 0.018 \\
\hline \multirow[t]{5}{*}{7.82} & \multirow[t]{5}{*}{ Acenaphthene } & \multirow[t]{5}{*}{$\begin{array}{l}\text { Acenaphthylene- } \\
D_{8}\end{array}$} & 155 & 154 & 20 & 0.539 \\
\hline & & & & 153 & 20 & Q \\
\hline & & & & 129.2 & 20 & 0.367 \\
\hline & & & & 128 & 30 & 0.317 \\
\hline & & & 154 & 153 & 20 & 0.852 \\
\hline \multirow[t]{5}{*}{8.42} & \multirow[t]{5}{*}{ Fluorene } & \multirow[t]{5}{*}{$\begin{array}{l}\text { Acenaphthylene- } \\
D_{8}\end{array}$} & 167 & 166 & 20 & 0.349 \\
\hline & & & & 165.1 & 20 & Q \\
\hline & & & & 152 & 20 & 0.956 \\
\hline & & & & 115 & 30 & 0.064 \\
\hline & & & 166 & 165.1 & 20 & 0.607 \\
\hline \multirow[t]{5}{*}{8.72} & \multirow[t]{5}{*}{ Diphenylamine } & \multirow[t]{5}{*}{ Tebuconazole- $\mathrm{D}_{6}$} & 170 & 93 & 30 & Q \\
\hline & & & & 168 & 30 & 0.035 \\
\hline & & & & 153 & 20 & 0.086 \\
\hline & & & & 152 & 20 & 0.070 \\
\hline & & & 169 & 168 & 20 & 0.506 \\
\hline \multirow[t]{4}{*}{8.87} & \multirow[t]{4}{*}{ HCB } & $\mathrm{HCB}-{ }^{13} \mathrm{C}_{6}$ & 282 & 247 & 30 & Q \\
\hline & & & & 212.1 & 30 & 0.718 \\
\hline & & & & 177 & 40 & 0.557 \\
\hline & & & & 142 & 50 & 0.435 \\
\hline 8.86 & $\mathrm{HCB}-{ }^{13} \mathrm{C}_{6}$ & & 292 & 222 & 40 & Q \\
\hline 9.01 & Ethoxyquin & Tebuconazole- $\mathrm{D}_{6}$ & 218 & 202 & 20 & 0.576 \\
\hline & & & & 174 & 20 & Q \\
\hline & & & & 148 & 20 & 0.671 \\
\hline & & & & 160 & 30 & 0.510 \\
\hline & & & 217 & 202 & 10 & 0.273 \\
\hline 9.81 & Phenanthrene- $\mathrm{D}_{10}$ & & 188 & 186.4 & 20 & Q \\
\hline 9.85 & Phenanthrene & Phenanthrene- $\mathrm{D}_{10}$ & 179 & 178.1 & 20 & Q \\
\hline & & & & 176.7 & 30 & 0.025 \\
\hline & & & & 176.1 & 40 & 0.044 \\
\hline & & & & 152.1 & 30 & 0.083 \\
\hline & & & 178 & 152 & 30 & 0.083 \\
\hline 9.88 & Anthracene & Phenanthrene- $\mathrm{D}_{10}$ & 179 & 178 & 20 & Q \\
\hline & & & & 176.7 & 30 & 0.025 \\
\hline & & & & 176.1 & 50 & 0.026 \\
\hline & & & & 152.1 & 30 & 0.069 \\
\hline & & & 178 & 152 & 30 & 0.112 \\
\hline 9.98 & PCB 28 & 4-4'-DDE D 8 & 256 & 221 & 20 & 0.060 \\
\hline & & & & 186 & 30 & Q \\
\hline & & & & 151 & 40 & 0.177 \\
\hline 10.07 & Fluazinam & Tebuconazole- $\mathrm{D}_{6}$ & 465 & 372.9 & 20 & Q \\
\hline & & & & 337.7 & 40 & 0.087 \\
\hline & & & & 303.9 & 40 & 0.077 \\
\hline & & & & 268.9 & 50 & 0.045 \\
\hline
\end{tabular}


Table 1 (continuation)

\begin{tabular}{|c|c|c|c|c|c|c|}
\hline Rt (min) & Compound & Internal Standard & Precursor ion & Product ion & CE (EV) & q/Q ratio \\
\hline \multirow[t]{4}{*}{10.25} & Chlorpyrifos-methyl & Tebuconazole- $\mathrm{D}_{6}$ & 322 & 290 & 10 & 0.161 \\
\hline & & & & 212 & 30 & 0.065 \\
\hline & & & & 177 & 40 & 0.021 \\
\hline & & & & 125 & 20 & $\mathrm{Q}$ \\
\hline \multirow[t]{4}{*}{10.39} & PCB 52 & 4-4'-DDE D 8 & 290 & 220 & 30 & $\mathrm{Q}$ \\
\hline & & & 292 & 257 & 20 & 0.605 \\
\hline & & & & 220 & 30 & 0.689 \\
\hline & & & & 150 & 50 & 0.334 \\
\hline \multirow[t]{4}{*}{10.41} & Pirimiphos-methyl & Tebuconazole- $\mathrm{D}_{6}$ & 306 & 164 & 20 & $\mathrm{Q}$ \\
\hline & & & & 108 & 40 & 0.505 \\
\hline & & & & 125 & 30 & 0.269 \\
\hline & & & & 95 & 20 & 0.145 \\
\hline \multirow[t]{5}{*}{10.71} & Malathion & Tebuconazole-- $\mathrm{D}_{6}$ & 331 & 211 & 10 & 0.026 \\
\hline & & & & 143 & 30 & 0.017 \\
\hline & & & & 125 & 30 & Q \\
\hline & & & & 117 & 20 & 0.047 \\
\hline & & & & 99 & 10 & 0.732 \\
\hline \multirow[t]{4}{*}{11.69} & PCB 101 & 4-4'-DDE D 8 & 324 & 254 & 40 & Q \\
\hline & & & 326 & 291 & 20 & 0.938 \\
\hline & & & & 256 & 40 & 0.936 \\
\hline & & & & 184 & 50 & 0.081 \\
\hline 12.17 & Fluoranthene- $\mathrm{D}_{10}$ & & 212.2 & 210.3 & 30 & Q \\
\hline \multirow[t]{5}{*}{12.22} & Fluoranthene & Fluoranthene- $\mathrm{D}_{10}$ & 203 & 202.1 & 30 & Q \\
\hline & & & & 200 & 40 & 0.069 \\
\hline & & & & 175.9 & 50 & 0.007 \\
\hline & & & & 152 & 50 & 0.014 \\
\hline & & & 202 & 200.8 & 30 & 0.053 \\
\hline 12.30 & 4,4'-DDE-D 8 & & 324 & 254 & 40 & $\mathrm{Q}$ \\
\hline \multirow[t]{4}{*}{12.34} & 4,4'-DDE & 4-4'-DDE D 8 & 316 & 246.1 & 30 & Q \\
\hline & & & & 210 & 40 & 0.083 \\
\hline & & & & 281 & 20 & 0.162 \\
\hline & & & & 176 & 50 & 0.483 \\
\hline \multirow[t]{5}{*}{12.51} & Imazalil & Tebuconazole- $\mathrm{D}_{6}$ & 297 & 254.8 & 10 & 0.031 \\
\hline & & & & 201.1 & 10 & 0.050 \\
\hline & & & & 176.3 & 20 & 0.334 \\
\hline & & & & 159 & 20 & Q \\
\hline & & & & 109 & 20 & 0.259 \\
\hline 12.93 & Pyrene- $\mathrm{D}_{10}$ & & 212.2 & 210.3 & 30 & $\mathrm{Q}$ \\
\hline \multirow[t]{5}{*}{12.97} & Pyrene & Pyrene- $\mathrm{D}_{10}$ & 203 & 202.2 & 30 & Q \\
\hline & & & & 200.8 & 40 & 0.067 \\
\hline & & & & 200 & 50 & 0.041 \\
\hline & & & & 176.1 & 50 & 0.003 \\
\hline & & & 202 & 200.8 & 30 & 0.039 \\
\hline \multirow[t]{4}{*}{13.03} & PCB 118 & 4-4'-DDE D 8 & 326 & 291 & 20 & 0.107 \\
\hline & & & & 256 & 40 & Q \\
\hline & & & & 184 & 50 & 0.470 \\
\hline & & & 324 & 254 & 40 & 0.968 \\
\hline \multirow[t]{4}{*}{13.28} & PCB 153 & ${ }^{13} \mathrm{C}_{12}$-PCB 153 & 360 & 325 & 20 & 0.478 \\
\hline & & & & 290 & 40 & Q \\
\hline & & & & 218 & 60 & 0.551 \\
\hline & & & 358 & 253 & 50 & 0.151 \\
\hline 13.27 & PCB $153-{ }^{13} \mathrm{C}_{12}$ & & 376 & 306 & 40 & Q \\
\hline \multirow[t]{3}{*}{13.65} & 4,4'-DDD & Tebuconazole- $\mathrm{D}_{6}$ & 235 & 165 & 20 & Q \\
\hline & & & & 115 & 50 & 0.028 \\
\hline & & & & 99 & 40 & 0.029 \\
\hline
\end{tabular}


Table 1 (continuation)

\begin{tabular}{|c|c|c|c|c|c|c|}
\hline $\begin{array}{l}\mathrm{Rt} \\
(\min )\end{array}$ & Compound & $\begin{array}{l}\text { Internal } \\
\text { Standard }\end{array}$ & $\begin{array}{l}\text { Precursor } \\
\text { Ion }\end{array}$ & $\begin{array}{l}\text { Product } \\
\text { Ion }\end{array}$ & $\begin{array}{l}\mathrm{CE} \\
(\mathrm{eV})\end{array}$ & $\begin{array}{l}\mathrm{q} / \mathrm{Q} \\
\text { ratio }\end{array}$ \\
\hline \multirow[t]{5}{*}{13.98} & $\mathrm{~B}[\mathrm{c}] \mathrm{F}$ & Pyrene- $\mathrm{D}_{10}$ & 217 & 215.9 & 20 & 0.129 \\
\hline & & & & 215 & 30 & 0.370 \\
\hline & & & & 202 & 30 & Q \\
\hline & & & & 200.1 & 40 & 0.048 \\
\hline & & & 216 & 215 & 30 & 0.393 \\
\hline \multirow[t]{4}{*}{14.27} & PCB 138 & ${ }^{13} \mathrm{C}_{12}$-PCB 153 & 360 & 325 & 20 & 0.683 \\
\hline & & & & 290 & 40 & Q \\
\hline & & & & 218 & 60 & 0.559 \\
\hline & & & 358 & 253 & 50 & 0.150 \\
\hline \multirow[t]{3}{*}{14.31} & 4,4'-DDT & 4-4'-DDE $\mathrm{D}_{8}$ & 235 & 165 & 20 & Q \\
\hline & & & & 115 & 50 & 0.026 \\
\hline & & & & 99 & 40 & 0.023 \\
\hline 14.64 & Tebuconazole- $\mathrm{D}_{6}$ & & 314 & 296 & 10 & Q \\
\hline \multirow[t]{4}{*}{14.70} & Tebuconazole & Tebuconazole-- $\mathrm{D}_{6}$ & 308 & 290 & 10 & Q \\
\hline & & & & 165 & 20 & 0.430 \\
\hline & & & & 151 & 20 & 0.246 \\
\hline & & & & 125 & 40 & 0.865 \\
\hline \multirow[t]{4}{*}{15.67} & PCB 180 & ${ }^{13} \mathrm{C}_{12}$-PCB 153 & 392 & 322 & 40 & 0.557 \\
\hline & & & 394 & 324 & 30 & Q \\
\hline & & & 396 & 361 & 20 & 0.454 \\
\hline & & & & 254 & 60 & 0.448 \\
\hline \multirow[t]{5}{*}{16.80} & $\mathrm{~B}[\mathrm{a}] \mathrm{A}$ & Pyrene- $\mathrm{D}_{10}$ & 229 & 228 & 40 & Q \\
\hline & & & & 226.9 & 30 & 0.262 \\
\hline & & & & 226 & 40 & 0.629 \\
\hline & & & & 202.2 & 30 & 0.148 \\
\hline & & & 228 & 226 & 40 & 0.568 \\
\hline \multirow[t]{4}{*}{17.07} & $\mathrm{C}[\mathrm{c}, \mathrm{d}] \mathrm{P}$ & Pyrene- $\mathrm{D}_{10}$ & 227 & 226 & 30 & Q \\
\hline & & & & 225 & 40 & 0.076 \\
\hline & & & & 200.8 & 40 & 0.002 \\
\hline & & & 226 & 224.9 & 40 & 0.039 \\
\hline \multirow[t]{5}{*}{17.11} & Chrysene & Pyrene- $\mathrm{D}_{10}$ & 229 & 227.9 & 40 & Q \\
\hline & & & & 227 & 30 & 0.440 \\
\hline & & & & 226 & 40 & 0.842 \\
\hline & & & & 202.1 & 30 & 0.219 \\
\hline & & & 228 & 226 & 40 & 0.579 \\
\hline \multirow[t]{5}{*}{18.75} & 5-MC & Pyrene- $\mathrm{D}_{10}$ & 243 & 242 & 30 & 0.043 \\
\hline & & & & 228 & 30 & Q \\
\hline & & & & 226.1 & 40 & 0.261 \\
\hline & & & & 202.1 & 40 & 0.066 \\
\hline & & & 242 & 241.1 & 20 & 0.227 \\
\hline \multirow[t]{5}{*}{19.96} & Ethoxyquin dimer & Tebuconazole- $\mathrm{D}_{6}$ & 433 & 418 & 10 & 0.076 \\
\hline & & & & 216 & 20 & Q \\
\hline & & & & 188 & 30 & 0.744 \\
\hline & & & 432 & 417 & 20 & 0.307 \\
\hline & & & & 173 & 50 & 0.354 \\
\hline \multirow[t]{5}{*}{21.06} & $\mathrm{~B}[\mathrm{~b}] \mathrm{F}$ & $\mathrm{B}[\mathrm{a}] \mathrm{P}-\mathrm{D}_{12}$ & 253 & 251.9 & 30 & Q \\
\hline & & & & 250.8 & 40 & 0.064 \\
\hline & & & & 250.1 & 50 & 0.349 \\
\hline & & & & 226 & 50 & 0.051 \\
\hline & & & 252 & 250 & 40 & 0.188 \\
\hline \multirow[t]{5}{*}{21.16} & $\mathrm{~B}[\mathrm{k}] \mathrm{F}$ & $\mathrm{B}[\mathrm{a}] \mathrm{P}-\mathrm{D}_{12}$ & 253 & 251.9 & 30 & Q \\
\hline & & & & 250.8 & 40 & 0.046 \\
\hline & & & & 250.1 & 50 & 0.174 \\
\hline & & & & 226 & 50 & 0.011 \\
\hline & & & 252 & 250 & 40 & 0.165 \\
\hline
\end{tabular}


Table 1 (continuation)

\begin{tabular}{|c|c|c|c|c|c|c|}
\hline $\begin{array}{l}\mathrm{Rt} \\
(\mathrm{min})\end{array}$ & Compound & $\begin{array}{l}\text { Internal } \\
\text { Standard }\end{array}$ & $\begin{array}{l}\text { Precursor } \\
\text { Ion }\end{array}$ & $\begin{array}{l}\text { Product } \\
\text { Ion }\end{array}$ & $\begin{array}{l}\mathrm{CE} \\
(\mathrm{eV})\end{array}$ & $\begin{array}{l}\mathrm{q} / \mathrm{Q} \\
\text { ratio }\end{array}$ \\
\hline \multirow[t]{5}{*}{22.28} & $\mathrm{~B}[\mathrm{j}] \mathrm{F}$ & $\mathrm{B}[\mathrm{a}] \mathrm{P}-\mathrm{D}_{12}$ & 253 & 251.9 & 30 & 0.899 \\
\hline & & & & 248.6 & 60 & 0.020 \\
\hline & & & & 226 & 50 & 0.269 \\
\hline & & & & 224.1 & 60 & 0.120 \\
\hline & & & 252 & 250 & 40 & $\mathrm{Q}$ \\
\hline \multirow[t]{4}{*}{21.97} & Boscalid & Tebuconazole-- $\mathrm{D}_{6}$ & 343 & 307 & 20 & 0.336 \\
\hline & & & & 140 & 20 & $\mathrm{Q}$ \\
\hline & & & & 112 & 40 & 0.413 \\
\hline & & & 342 & 140 & 20 & 0.039 \\
\hline 22.75 & $\mathrm{~B}[\mathrm{a}] \mathrm{P}-\mathrm{D}_{12}$ & & 264.3 & 262.3 & 30 & $\mathrm{Q}$ \\
\hline \multirow[t]{5}{*}{22.66} & $\mathrm{~B}[\mathrm{a}] \mathrm{P}$ & $\mathrm{B}[\mathrm{a}] \mathrm{P}-\mathrm{D}_{12}$ & 253 & 252.1 & 30 & $\mathrm{Q}$ \\
\hline & & & & 250.7 & 40 & 0.023 \\
\hline & & & & 250.2 & 50 & 0.201 \\
\hline & & & & 226 & 50 & 0.037 \\
\hline & & & 252 & 250 & 40 & 0.146 \\
\hline \multirow[t]{5}{*}{24.97} & Azoxystrobin & Tebuconazole-- $\mathrm{D}_{6}$ & 404 & 372 & 10 & \\
\hline & & & & 344 & 20 & 0.243 \\
\hline & & & & 329 & 30 & 0.414 \\
\hline & & & & 172 & 50 & 0.212 \\
\hline & & & & 156 & 50 & 0.211 \\
\hline \multirow[t]{3}{*}{25.19} & $\mathrm{I}[1,2,3-\mathrm{cd}] \mathrm{P}$ & $\mathrm{B}[\mathrm{g}, \mathrm{h}, \mathrm{i}] \mathrm{Pe}-\mathrm{D}_{12}$ & 277 & 276.1 & 30 & Q \\
\hline & & & & 275.4 & 50 & 0.123 \\
\hline & & & & 274.3 & 50 & 0.192 \\
\hline \multirow[t]{4}{*}{25.22} & $\mathrm{D}[\mathrm{a}, \mathrm{h}] \mathrm{A}$ & $\mathrm{B}[\mathrm{a}] \mathrm{P}-\mathrm{D}_{12}$ & 279 & 278.1 & 30 & Q \\
\hline & & & & 276.8 & 40 & 0.161 \\
\hline & & & & 275.9 & 40 & 0.333 \\
\hline & & & & 263.3 & 30 & 0.267 \\
\hline 25.87 & $\mathrm{~B}[\mathrm{~g}, \mathrm{~h}, \mathrm{i}] \mathrm{Pe}-\mathrm{D}_{12}$ & & 288.2 & 286.3 & 30 & $\mathrm{Q}$ \\
\hline \multirow[t]{5}{*}{25.93} & $\mathrm{~B}[\mathrm{~g}, \mathrm{~h}, \mathrm{i}] \mathrm{Pe}$ & $\mathrm{B}[\mathrm{g}, \mathrm{h}, \mathrm{i}] \mathrm{Pe}-\mathrm{D}_{12}$ & 277 & 276.2 & 40 & $\mathrm{Q}$ \\
\hline & & & & 275.1 & 50 & 0.153 \\
\hline & & & & 274 & 50 & 0.154 \\
\hline & & & & 272.7 & 60 & 0.005 \\
\hline & & & 276 & 275.1 & 50 & 0.053 \\
\hline \multirow{5}{*}{28.86} & $\mathrm{D}[\mathrm{a}, 1] \mathrm{P}$ & $\mathrm{B}[\mathrm{g}, \mathrm{h}, \mathrm{i}] \mathrm{Pe}-\mathrm{D}_{12}$ & 303 & 302.1 & 30 & $\mathrm{Q}$ \\
\hline & & & & 300.8 & 30 & 0.067 \\
\hline & & & & 300 & 50 & 0.455 \\
\hline & & & & 276 & 40 & 0.057 \\
\hline & & & 302 & 300 & 50 & 0.288 \\
\hline \multirow[t]{5}{*}{29.92} & $\mathrm{D}[\mathrm{a}, \mathrm{e}] \mathrm{P}$ & $\mathrm{B}[\mathrm{g}, \mathrm{h}, \mathrm{i}] \mathrm{Pe}-\mathrm{D}_{12}$ & 303 & 302.1 & 30 & Q \\
\hline & & & & 300.1 & 50 & 0.341 \\
\hline & & & & 298.6 & 60 & 0.008 \\
\hline & & & & 297.9 & 60 & 0.022 \\
\hline & & & 302 & 300 & 50 & 0.183 \\
\hline \multirow[t]{5}{*}{30.59} & $\mathrm{D}[\mathrm{a}, \mathrm{i}] \mathrm{P}$ & $\mathrm{B}[\mathrm{g}, \mathrm{h}, \mathrm{i}] \mathrm{Pe}-\mathrm{D}_{12}$ & 303 & 302.1 & 30 & $\mathrm{Q}$ \\
\hline & & & & 300.1 & 50 & 0.245 \\
\hline & & & & 297.9 & 60 & 0.019 \\
\hline & & & & 276 & 50 & 0.033 \\
\hline & & & 302 & 300 & 50 & 0.178 \\
\hline \multirow[t]{5}{*}{31.00} & $\mathrm{D}[\mathrm{a}, \mathrm{h}] \mathrm{P}$ & $\mathrm{B}[\mathrm{g}, \mathrm{h}, \mathrm{i}] \mathrm{Pe}-\mathrm{D}_{12}$ & 303 & 302.1 & 30 & $\mathrm{Q}$ \\
\hline & & & & 300.1 & 50 & 0.274 \\
\hline & & & & 297.9 & 60 & 0.019 \\
\hline & & & & 276 & 50 & 0.033 \\
\hline & & & 302 & 300 & 50 & 0.219 \\
\hline
\end{tabular}




\subsection{Selectivity of the SRM transitions for PAHs}

Selectivity of the selected SRM transitions, especially in cases where coelution occurred, was also studied during the optimization process. In such cases, the possibility of selecting different precursor ions for the same compound $\left(\mathrm{M}^{+\bullet}\right.$ or $\left.[\mathrm{M}+\mathrm{H}]^{+}\right)$was of great advance in terms of specificity. This was the case of the determination of cyclopenta(c,d)pyrene $\left(\mathrm{C}_{18} \mathrm{H}_{10}\right.$, $M W=226$ ), which nearly coelutes with chrysene $\left(\mathrm{C}_{18} \mathrm{H}_{12}, \mathrm{MW}=228\right)$ (see Fig. S2). Chrysene shows 226 as an in-source fragment (coming from $\mathbf{M}^{+\bullet} 228$ ). Thus, when monitoring $\mathrm{C}(\mathrm{c}, \mathrm{d}) \mathrm{P}$ with the transition coming from its $\mathrm{M}^{+\bullet} 226$, an interference from chrysene (coming from an in-source fragment) is observed in the chromatogram, which makes the peak area integration troublesome, especially when the concentration of chrysene is higher than cyclopenta(c,d)pyrene. However, quantification and confirmation transitions for $\mathrm{C}(\mathrm{c}, \mathrm{d}) \mathrm{P}$ coming from $[\mathrm{M}+\mathrm{H}]^{+} 227$ did not suffer from this interference and showed higher specificity, which is commonly observed on EI-based methods [36]. A similar case occurred for the determination of indeno(1,2,3-cd)pyrene $\left(\mathrm{C}_{22} \mathrm{H}_{12}, \mathrm{MW}=276\right)$ due to the nearly coelution of dibenzo(a,h)anthracene $\left(\mathrm{C}_{22} \mathrm{H}_{14}, \mathrm{MW}=278\right)$. $\mathrm{D}(\mathrm{a}, \mathrm{h}) \mathrm{A}$ shows an in-source fragment at $\mathrm{m} / \mathrm{z} 276$, so the transition coming from $\mathrm{M}^{+\bullet} 276$ for $\mathrm{I}(1,2,3, \mathrm{~cd}) \mathrm{P}$ was interfered by $\mathrm{D}(\mathrm{a}, \mathrm{h}) \mathrm{A}$, while those coming from $[\mathrm{M}+\mathrm{H}]^{+} 277$ were much cleaner. 


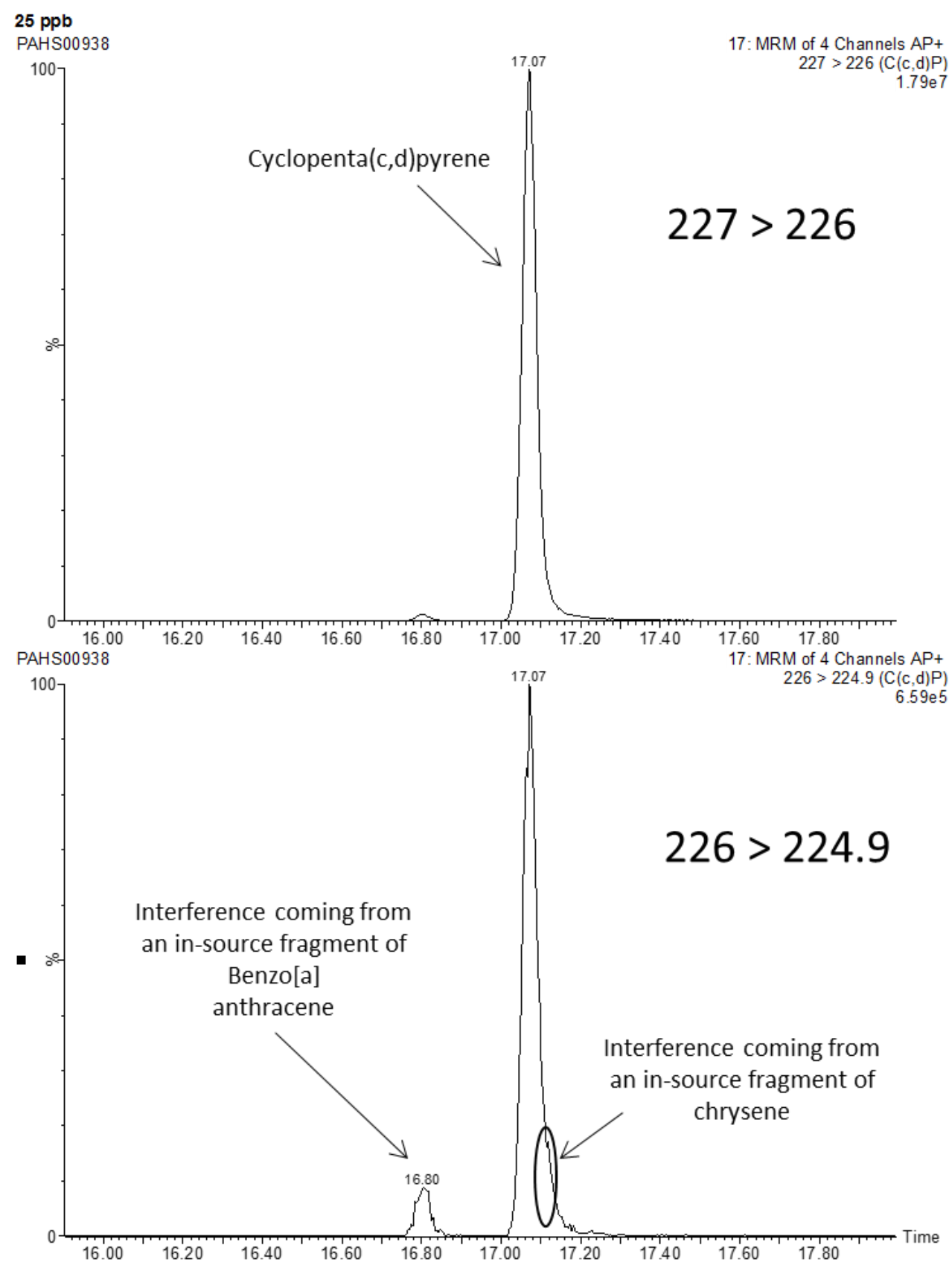

Figure S2. GC-APCI-MS/MS chromatogram of the triplet B[a]A, C[c,d]P and chrysene for (up) SRM transition coming from $[\mathrm{M}+\mathrm{H}]^{+}$and (down) SRM transition coming from $\mathrm{M}^{+\cdot}$. 


\subsection{Study of matrix effects}

Matrix effects observed under GC-APCI-MS come from the GC liner (normally signal enhancement) and from the APCI source (normally signal suppression) [27]. As a summary of the matrix effect study for 9 out of 19 matrices (where different dilution factors were tested: crude extract, 5-fold, 10-fold and 20-fold dilution), signal enhancement/suppression was observed for: i) $36 \%$ of the combinations matrix/PAHs, $58 \%$ for matrix/pesticides and $52 \%$ for matrix/PCBs (crude extract); ii) $35 \%$ for matrix/PAHs, $46 \%$ for matrix/pesticides and $17 \%$ for matrix/PCBs (5-fold dilution factor); iii) $26 \%$ of matrix/PAHs, $33 \%$ for matrix/pesticides and $14 \%$ for matrix/PCBs (10-fold dilution factor); and iv) $11 \%$ for matrix/pesticides (20-fold dilution factor). As an illustrative example, Fig. 3 shows how the matrix effect for PAHs in sea bream fillet decreases when the different dilution factors studied are applied. Thus, 20-fold dilution of the final extract was finally selected for further experiments.

As a summary, for a 20 -fold dilution, signal enhancement was observed only for ethoxyquin and ethoxyquin-dimer, whereas signal suppression was observed for boscalid and azoxystrobin (mainly in plant and marine ingredients). No significant matrix effect was observed for PAHs, PCBs and the rest of pesticides (Fig. S3). According to our data, 20-fold dilution of the final sample extract eliminated matrix effect for most analyte/matrix combinations, and this allowed us to perform the quantification in the analysis of the 19 aquaculture matrices using calibration curve in solvent. The remaining matrix effects for boscalid and azoxystrobin could be corrected with the use of SIL-IS. Matrix effect for ethoxyquin and ethoxyquin-dimer could not be properly evaluated in feed, krill meal and fishmeal matrices because the 
analyte concentration in these samples was typically higher than the spiking levels assayed.

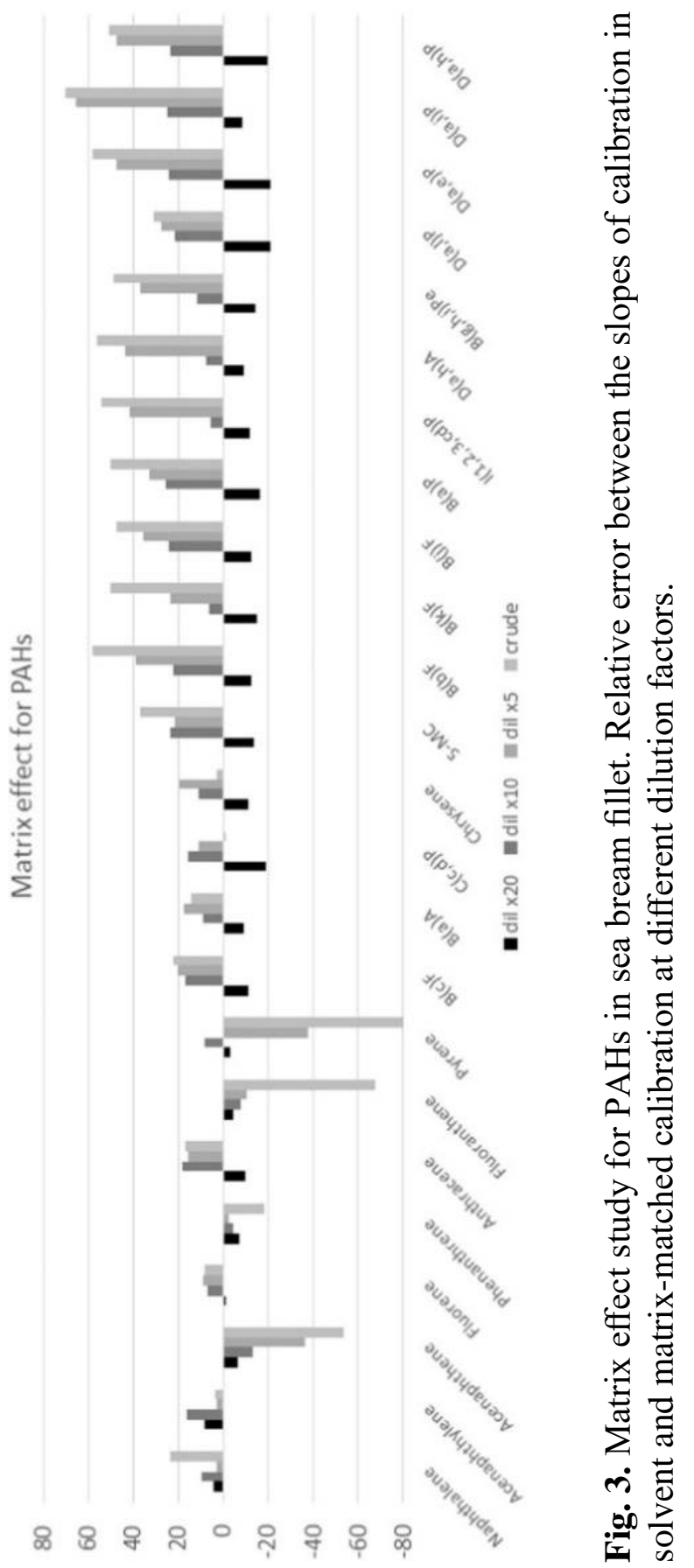

T. Portolés et al., Talanta 172 (2017) 109-119 

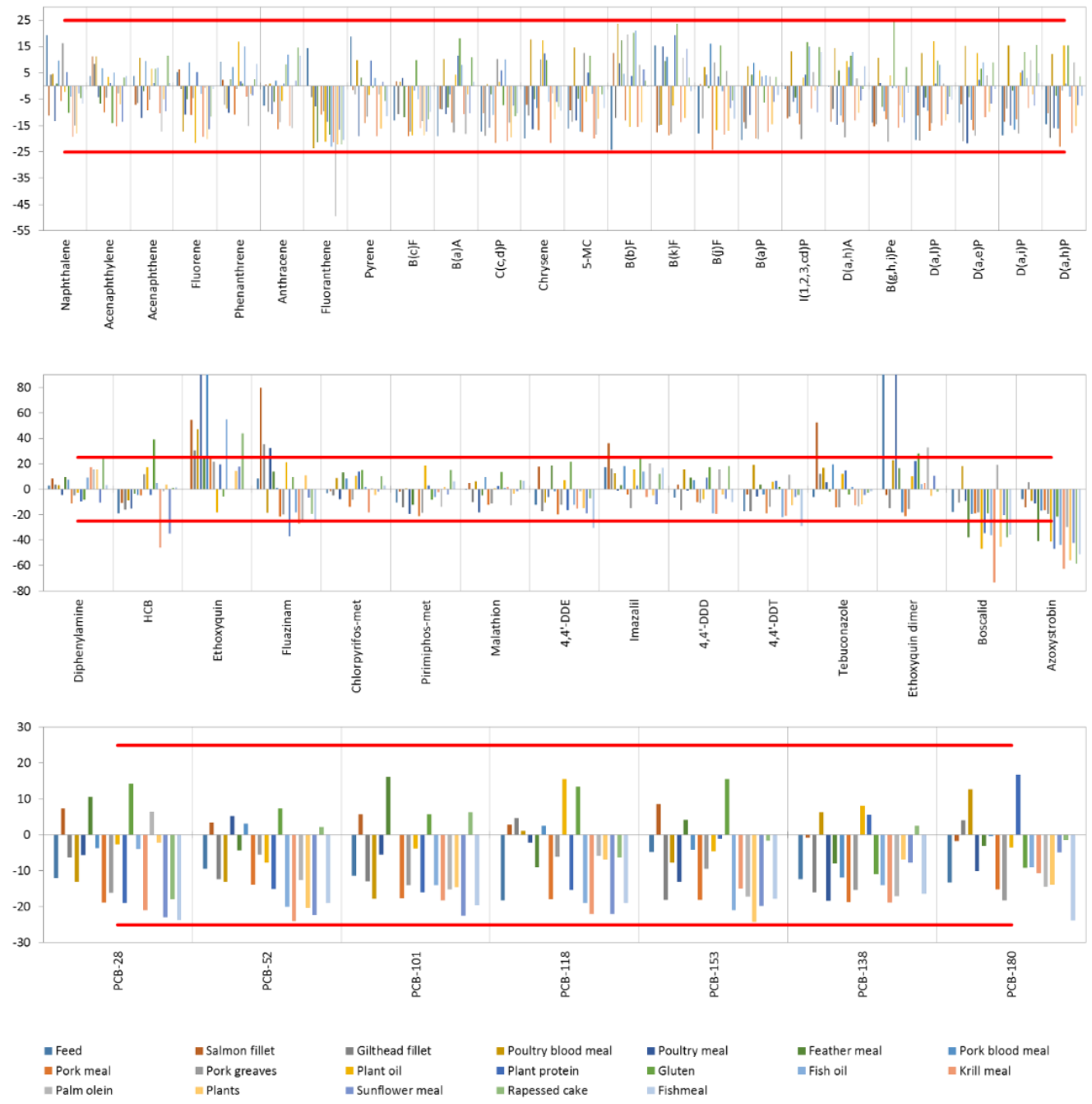

Figure S3. Matrix effect observed for a 20-fold dilution factor.

\subsection{Analytical parameters}

Validation of the analytical procedure was carried out in salmon and sea bream fillets considering the parameters of linearity, accuracy, precision, LODs and LOQs. Relative responses to the selected SIL-IS were used (see Table 1). 
The study of the linearity revealed that correlation coefficients $\left(\mathrm{R}^{2}\right)$ were higher than 0.99 , with residuals lower than $30 \%$ for most compounds in the range $0.01-25 \mathrm{ng} \cdot \mathrm{mL}^{-1}$. Some exceptions were: $0.0125-12.5 \mathrm{ng} \cdot \mathrm{mL}^{-1}$ $(\mathrm{C}[\mathrm{c}, \mathrm{d}] \mathrm{P}) ; 0.025-25 \mathrm{ng} \cdot \mathrm{mL}^{-1}$ (naphthalene, acenaphthylene, acenaphthene, anthracene, B[c]F, B[a]A, chrysene, B[b]F, B[k]F, B[j]F, D[a,h]A, PCB 153 and 180, diphenylamine, tebuconazole, ethoxyquin dimer, boscalid and azoxystrobin); 0.1-25 ng. $\mathrm{mL}^{-1}$ (D[a,l] P and D[a,e]P, HCB and p, $\left.\mathrm{p}^{\prime}-\mathrm{DDE}\right)$; 0.5-25 ng. $\mathrm{mL}^{-1}\left(\mathrm{D}[\mathrm{a}, \mathrm{i}] \mathrm{P}, \mathrm{D}[\mathrm{a}, \mathrm{h}] \mathrm{P}\right.$, ethoxyquin, fluazinam, imazalil, $\mathrm{p}, \mathrm{p}^{\prime}-\mathrm{DDD}$ and $\left.\mathrm{p}, \mathrm{p}^{\prime}-\mathrm{DDT}\right)$.

Trueness and precision data for salmon and sea bream fillets are shown in Table 2 which shows satisfactory recoveries and precision for the wide majority of compounds at the two concentrations studied, 2 and $50 \mathrm{ng} \cdot \mathrm{g}^{-1}$. A LOQ objective of $2 \mathrm{ng} \cdot \mathrm{g}^{-1}$ was empirically demonstrated for most compounds in both matrices, using samples spiked at this level and subjected to the overall analytical procedure. A statistical LOQ of $5 \mathrm{ng} \cdot \mathrm{g}^{-1}(\mathrm{~S} / \mathrm{N}=10)$ was estimated for naphthalene, fluorene, fluoranthene and pyrene, as the high concentrations present in the "blank" samples did not allow the calculation of recoveries and precision below that concentration. Dibenzopyrenes have poor response, and therefore the LOQ was established in $50 \mathrm{ng} \cdot \mathrm{g}^{-1}$. The same occurred for HCB, fluazinam, imazalil, $\mathrm{p}, \mathrm{p}^{\prime}$-DDE, $\mathrm{p}, \mathrm{p}^{\prime}$-DDD and $\mathrm{p}, \mathrm{p}^{\prime}$ - DDT which could not be detected at the low level of $2 \mathrm{ng} \cdot \mathrm{g}^{-1}$ being $50 \mathrm{ng} \cdot \mathrm{g}^{-1}$ still the normally applied MRL for these compounds (as commented above, these compounds were negatively affected by the introduction of water as modifier in the source). Similarly to some light PAHs, ETQ and ETQ-D were found at quite high concentrations in the samples impeding validation at $2 \mathrm{ng} \cdot \mathrm{g}^{-1}$ level. Thus, LOQs were statistically calculated for $\mathrm{S} / \mathrm{N}=10$. LODs were found to be between $0.5-2 \mathrm{ng} \cdot \mathrm{g}^{-1}$ for $80 \%$ of the PAHs, all the PCBs and $50 \%$ of the 
pesticides studied. The rest of compounds showed LODs between 5 and 50 $\mathrm{ng} \cdot \mathrm{g}^{-1}$.

In relation to the remaining 17 matrices, a total of 48 QC samples, spiked at 5 $\mathrm{ng} \cdot \mathrm{g}^{-1}$ and $50 \mathrm{ng} \cdot \mathrm{g}^{-1}$, were analyzed. Fig.4 shows the boxplot diagrams representing the recovery values for PAHs in all matrices at the two concentrations assayed. Some recoveries could not be calculated (e.g. napthalene, fluorene, phenanthrene, pyrene, $\mathrm{D}[\mathrm{a}, \mathrm{e}] \mathrm{P}, \mathrm{D}[\mathrm{a}, \mathrm{i}] \mathrm{P}$ and $\mathrm{D}[\mathrm{a}, \mathrm{h}] \mathrm{P})$ at $5 \mathrm{ng} \cdot \mathrm{g}^{-1}$ spiking level due to the high analyte concentration present in "blank" sample. It can be emphasized that all QC recoveries were in the range 60 $140 \%$, with median values between $88 \%$ and $115 \%$, at $5 \mathrm{ng} \cdot \mathrm{g}^{-1}$, and between $92 \%$ and $116 \%$ at $50 \mathrm{ng} \cdot \mathrm{g}^{-1}$. Among the studied matrices, PAPs showed higher complexity giving individual recoveries out of 70-120\% range without a clear tendency for specific compounds. Data from above illustrate that the methodology applied was robust and satisfactory for the determination of very low PAH concentrations in different sample matrices, some of them of high complexity. The excellent sensitivity of GC-APCI-MS/MS allowed the extra dilution (x20) of the sample extracts, minimizing matrix effects but still reaching low LOQs, comparable and, in some cases, even lower than those reported in the literature $[21,22]$ with the great advantage of using solvent calibration for quantification of the compounds in all matrices tested. 
Table 2: Mean recoveries (\%) and precision (RSD, \%) for PAHs, PCBs and pesticides after application of overall analytical procedure to salmon fillet and gilthead fillet $(n=6)$, LOQs objective of the method.

\begin{tabular}{|c|c|c|c|c|c|c|}
\hline \multirow[t]{3}{*}{ Compounds } & \multicolumn{3}{|c|}{ Salmon fillet } & \multicolumn{3}{|c|}{ Sea bream fillet } \\
\hline & \multicolumn{2}{|c|}{$\begin{array}{l}\text { Spiking levels } \\
\left(\mathrm{ng} \cdot \mathrm{g}^{-1}\right)\end{array}$} & \multirow[t]{2}{*}{$\begin{array}{l}\text { LOQ } \\
\text { objective } \\
\left(\mathrm{ng} \cdot \mathrm{g}^{-1}\right)\end{array}$} & \multicolumn{2}{|c|}{$\begin{array}{l}\text { Spiking levels } \\
\left(\text { ng. } \mathrm{g}^{-1}\right)\end{array}$} & \multirow[t]{2}{*}{$\begin{array}{l}\text { LOQ } \\
\text { objective } \\
\left(\mathrm{ng} \cdot \mathrm{g}^{-1}\right)\end{array}$} \\
\hline & 2 & 50 & & 2 & 50 & \\
\hline Naphthalene & $\mathrm{a}$ & $98(18)$ & $5^{b}$ & a & $98(17)$ & $5^{\mathrm{b}}$ \\
\hline Acenaphthylene & $119(11)$ & $101(7)$ & 2 & $106(8)$ & $103(2)$ & 2 \\
\hline Acenaphthene & 74 (19) & $72(6)$ & 2 & $93(12)$ & $73(3)$ & 2 \\
\hline Fluorene & a & $95(11)$ & $5^{\mathrm{b}}$ & a & $108(6)$ & $5^{\mathrm{b}}$ \\
\hline Phenanthrene & a & $116(9)$ & $2^{\mathrm{b}}$ & a & $113(9)$ & $2^{\mathrm{b}}$ \\
\hline Anthracene & $91(8)$ & $104(5)$ & 2 & $101(8)$ & $107(6)$ & 2 \\
\hline Fluoranthene & a & $103(7)$ & $5^{\mathrm{b}}$ & a & $96(11)$ & $5^{\mathrm{b}}$ \\
\hline Pyrene & a & $106(7)$ & $5^{\mathrm{b}}$ & a & 99 (14) & $5^{\mathrm{b}}$ \\
\hline $\mathrm{B}(\mathrm{c}) \mathrm{F}$ & $98(11)$ & $94(8)$ & 2 & $90(3)$ & $90(2)$ & 2 \\
\hline $\mathrm{B}(\mathrm{a}) \mathrm{A}$ & $114(5)$ & $101(5)$ & 2 & $113(9)$ & $73(2)$ & 2 \\
\hline $\mathrm{C}(\mathrm{c}, \mathrm{d}) \mathrm{P}^{\mathrm{c}}$ & $108(7)$ & $115(4)$ & 1 & $112(19)$ & $112(7)$ & 1 \\
\hline Chrysene & $107(12)$ & $101(4)$ & 2 & $116(8)$ & $76(6)$ & 2 \\
\hline 5-MC & $117(5)$ & $102(5)$ & 2 & $108(7)$ & $75(3)$ & 2 \\
\hline $\mathrm{B}(\mathrm{b}) \mathrm{F}$ & $80(13)$ & $104(7)$ & 2 & $106(20)$ & $96(4)$ & 2 \\
\hline $\mathrm{B}(\mathrm{k}) \mathrm{F}$ & $71(8)$ & $103(6)$ & 2 & $78(7)$ & $86(4)$ & 2 \\
\hline$B(j) F$ & $104(17)$ & $76(4)$ & 2 & $115(18)$ & $102(5)$ & 2 \\
\hline $\mathrm{B}(\mathrm{a}) \mathrm{P}$ & $104(3)$ & $88(7)$ & 2 & $113(14)$ & $86(5)$ & 2 \\
\hline $\mathrm{I}(1,2,3, \mathrm{~cd}) \mathrm{P}$ & $83(12)$ & $104(5)$ & 2 & $112(9)$ & $102(3)$ & 2 \\
\hline $\mathrm{D}(\mathrm{a}, \mathrm{h}) \mathrm{A}$ & $113(11)$ & $100(5)$ & 2 & $109(11)$ & $81(6)$ & 2 \\
\hline $\mathrm{B}(\mathrm{g}, h, \mathrm{i}) \mathrm{Pe}$ & $84(8)$ & $101(4)$ & 2 & $98(20)$ & $101(3)$ & 2 \\
\hline $\mathrm{D}(\mathrm{a}, \mathrm{l}) \mathrm{P}$ & - & $97(4)$ & 50 & - & $77(6)$ & 50 \\
\hline $\mathrm{D}(\mathrm{a}, \mathrm{e}) \mathrm{P}$ & - & $95(8)$ & 50 & - & $72(9)$ & 50 \\
\hline $\mathrm{D}(\mathrm{a}, \mathrm{i}) \mathrm{P}$ & - & $86(13)$ & 50 & - & $95(13)$ & 50 \\
\hline $\mathrm{D}(\mathrm{a}, \mathrm{h}) \mathrm{P}$ & - & $81(10)$ & 50 & - & $73(6)$ & 50 \\
\hline Diphenylamine & $119(20)$ & $100(17)$ & 2 & - & $98(17)$ & 50 \\
\hline $\mathrm{HCB}$ & - & $112(11)$ & 50 & - & $116(17)$ & 50 \\
\hline Ethoxyquin & a & a & $15^{\mathrm{b}}$ & a & a & $75^{\mathrm{b}}$ \\
\hline Fluazinam & - & $76(4)$ & 50 & - & $107(15)$ & 50 \\
\hline $\begin{array}{l}\text { Chlorpiriphos- } \\
\text { methyl }\end{array}$ & $77(10)$ & $100(6)$ & 2 & $113(13)$ & $80(7)$ & 2 \\
\hline Pirimiphos-methyl & $92(12)$ & $82(4)$ & 2 & $115(13)$ & $110(9)$ & 2 \\
\hline Malathion & $95(20)$ & $94(13)$ & 2 & $90(11)$ & $104(10)$ & 2 \\
\hline $4,4^{\prime}-\mathrm{DDE}$ & - & $95(19)$ & 50 & - & $76(19)$ & 50 \\
\hline Imazalil & - & $87(8)$ & 50 & - & $112(14)$ & 50 \\
\hline $4,4^{\prime}-\mathrm{DDD}$ & - & $112(9)$ & 50 & - & $114(18)$ & 50 \\
\hline $4,4^{\prime}$-DDT & - & $109(9)$ & 50 & - & $115(11)$ & 50 \\
\hline Tebuconazole & $103(19)$ & $109(11)$ & 2 & $99(16)$ & $113(12)$ & 2 \\
\hline Ethoxyquin dimer & a & a & $5^{\mathrm{b}}$ & a & a & $15^{\mathrm{b}}$ \\
\hline Boscalid & $115(7)$ & $103(17)$ & 2 & $103(4)$ & $106(11)$ & 2 \\
\hline Azoxystrobin & $95(16)$ & $102(14)$ & 2 & $119(10)$ & $109(9)$ & 2 \\
\hline
\end{tabular}


Table 2 (continuation)

\begin{tabular}{|c|c|c|c|c|c|c|}
\hline \multirow[t]{3}{*}{ Compounds } & \multicolumn{3}{|c|}{ Salmon fillet } & \multicolumn{3}{|c|}{ Sea bream fillet } \\
\hline & \multicolumn{2}{|c|}{$\begin{array}{l}\text { Spiking levels } \\
\left(n g \cdot g^{-1}\right)\end{array}$} & \multirow[t]{2}{*}{$\begin{array}{l}\text { LOQ } \\
\text { objective } \\
\left(\mathrm{ng} \cdot \mathrm{g}^{-1}\right)\end{array}$} & \multicolumn{2}{|c|}{$\begin{array}{l}\text { Spiking levels } \\
\left(\mathrm{ng} \cdot \mathrm{g}^{-1}\right)\end{array}$} & \multirow[t]{2}{*}{$\begin{array}{l}\text { LOQ } \\
\text { objective } \\
\left(\mathrm{ng} \cdot \mathrm{g}^{-1}\right)\end{array}$} \\
\hline & 2 & 50 & & 2 & 50 & \\
\hline PCB-28 & $106(13)$ & $117(7)$ & 2 & $110(11)$ & $120(8)$ & 2 \\
\hline PCB-52 & 107 (19) & $100(12)$ & 2 & $98(20)$ & 97 (12) & 2 \\
\hline PCB-101 & $106(17)$ & $120(3)$ & 2 & $109(15)$ & $118(3)$ & 2 \\
\hline PCB-118 & $110(21)$ & $105(3)$ & 2 & $98(19)$ & $121(3)$ & 2 \\
\hline PCB-153 & $95(20)$ & $120(14)$ & 2 & $87(15)$ & $115(16)$ & 2 \\
\hline PCB-138 & $115(6)$ & $118(13)$ & 2 & $117(8)$ & $116(13)$ & 2 \\
\hline PCB-180 & $105(11)$ & $111(13)$ & 2 & $81(18)$ & $108(3)$ & 2 \\
\hline
\end{tabular}

${ }^{\mathrm{a}}$ Recoveries could not be calculated due to the high concentration in the blank samples.

${ }^{b}$ LOQ was estimated as the analyte concentration that produced a peak signal of ten times the background noise in the chromatogram at the lowest fortification level studied for each compound.

${ }^{\mathrm{c}} \mathrm{C}[\mathrm{c}, \mathrm{d}] \mathrm{P}$ spiked at $1 \mathrm{ng} \cdot \mathrm{g}^{-1}$ and $25 \mathrm{ng} \cdot \mathrm{g}^{-1}$. 

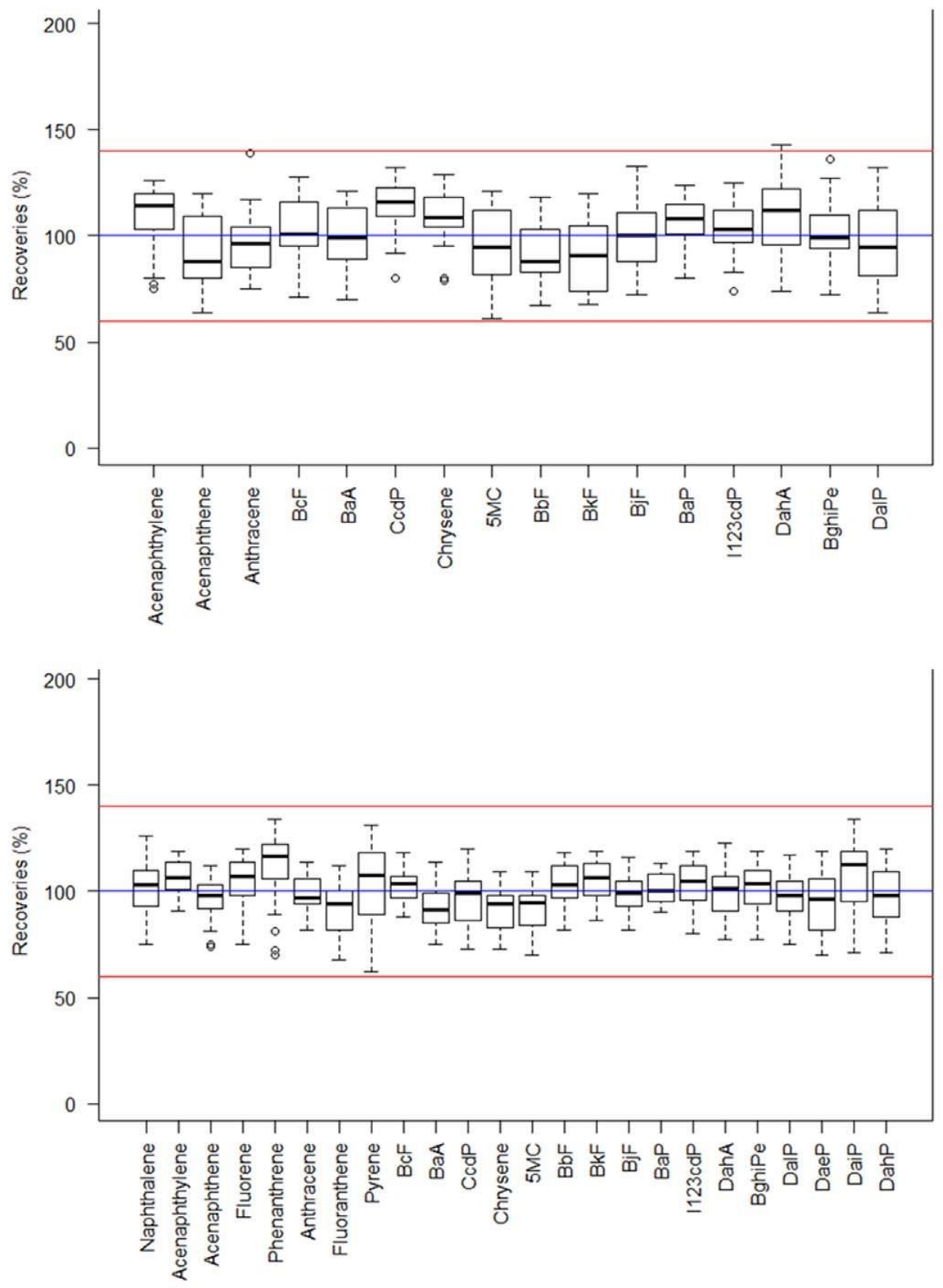

* Recoveries for naphthalene, fluorene, phenanthrene, pyrene, $D(a, e) P, D(a, i) P$ and $D(a, h) P$ could not be calculated at $5 \mathrm{ng} / \mathrm{g}$ spiking level due to the high concentration present in blank sample

Fig. 4. Box plots that shows the recoveries of the $48 \mathrm{QCs}$ (corresponding to 17 different matrices) spiked at 5 (up) and $50 \mathrm{ng} \cdot \mathrm{g}^{-1}$ (down). 


\subsection{Analysis of samples}

In order to demonstrate the applicability of the methodology developed in this paper, it was applied to the analysis of a notable number of samples from aquaculture production: 12 diets, 12 fish fillets, 19 terrestrial animal ingredients, 6 marine ingredients, 19 plant ingredients and 8 plant oils. A reagent blank and two spiked samples (5 and $50 \mathrm{ng} \cdot \mathrm{g}^{-1}$ ) for each matrix analyzed were included in each batch. The results, in Table S2, are expressed in a wet weight basis. The $\mathrm{q}_{\mathrm{i}} / \mathrm{Q}$ ratios obtained for all positive samples were within the range of the tolerance accepted (30\%) around the experimental $\mathrm{q}_{\mathrm{i}} / \mathrm{Q}$ value obtained from reference standards.

LMW-PAHs together with HMW-PAHs as fluoranthene and pyrene were found in most of the samples. Regarding diets, fish fillets, plant ingredients and PAPs, concentrations ranged from $<5 \mathrm{ng} \cdot \mathrm{g}^{-1}$ for acenaphthene to 126.6 , $77.1,88.6$ and $177.5 \mathrm{ng} \cdot \mathrm{g}^{-1}$ for naphthalene, respectively. In marine ingredients, they ranged from $<5 \mathrm{ng} \cdot \mathrm{g}^{-1}$ for acenaphthene and acenaphthylene to $129.0 \mathrm{ng} \cdot \mathrm{g}^{-1}$ for phenanthrene. For plant oil ingredients, concentrations ranged from $<5 \mathrm{ng} \cdot \mathrm{g}^{-1}$ for acenaphthylene to $186.9 \mathrm{ng} \cdot \mathrm{g}^{-1}$ for phenanthrene. In the present study only two fish oils were analyzed, and clearly a large variation exist in the environmental background levels of PAHs in fish oils $[13,14]$. Fig. $\mathbf{S 4}$ shows the identification of 5-MC in one fish meal. This PAH was below the LOQ in all samples analyzed. As can be seen, three transitions were acquired and $q_{i} / Q$ ratios were in agreement with SANTE/11945/2015 identification criteria followed in the current research [33].

Regarding pesticides, the non-organochlorine pesticides that are currently used on crop such as chlorpiriphos-methyl and pirimiphos-methyl were only 
detected in the novel plant ingredients and not in marine feed ingredients such as fish oil and meal [25]. Malathion, imazalil and tebuconazole were only found in some ingredients while boscalid and azoxystrobin were indeed found in feed. It is worth to mention that studied PCBs, DDTs and pesticides were not found in fillets from salmon and sea bream. The anti-oxidant ethoxyquin and its main metabolite ethoxyquin dimer are deposited to marine feed ingredients such as fish meal to prevent lipid oxidation and spontaneous combustion during overseas transport and storage (Lundebye et al., 2010). The ethoxyquin levels were highest in fish meal and krill (32,462 and 40,076 $\mathrm{ng} \cdot \mathrm{g}^{-1}$, respectively), but surprisingly high levels were also found in fish oil $\left(37,137 \mathrm{ng} \cdot \mathrm{g}^{-1}\right)$ where normally other antioxidant such as BHT and BHA are used [37]. All other feed ingredients, including terrestrial and plant, also contained ethoxyquin, albeit at 100-150 fold lower levels than the marine ingredients (Table S2). PCB congeners were not detected in any sample. 


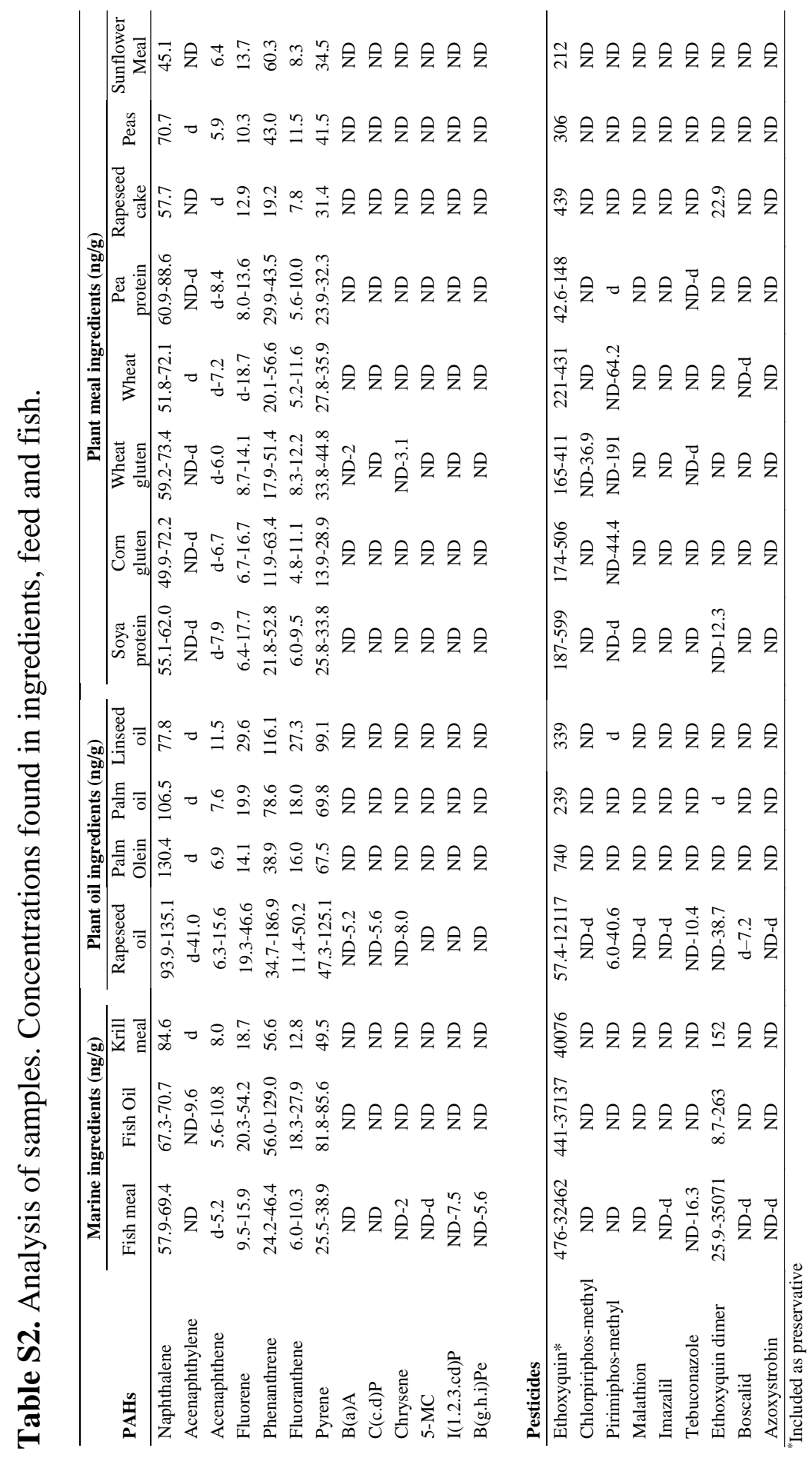




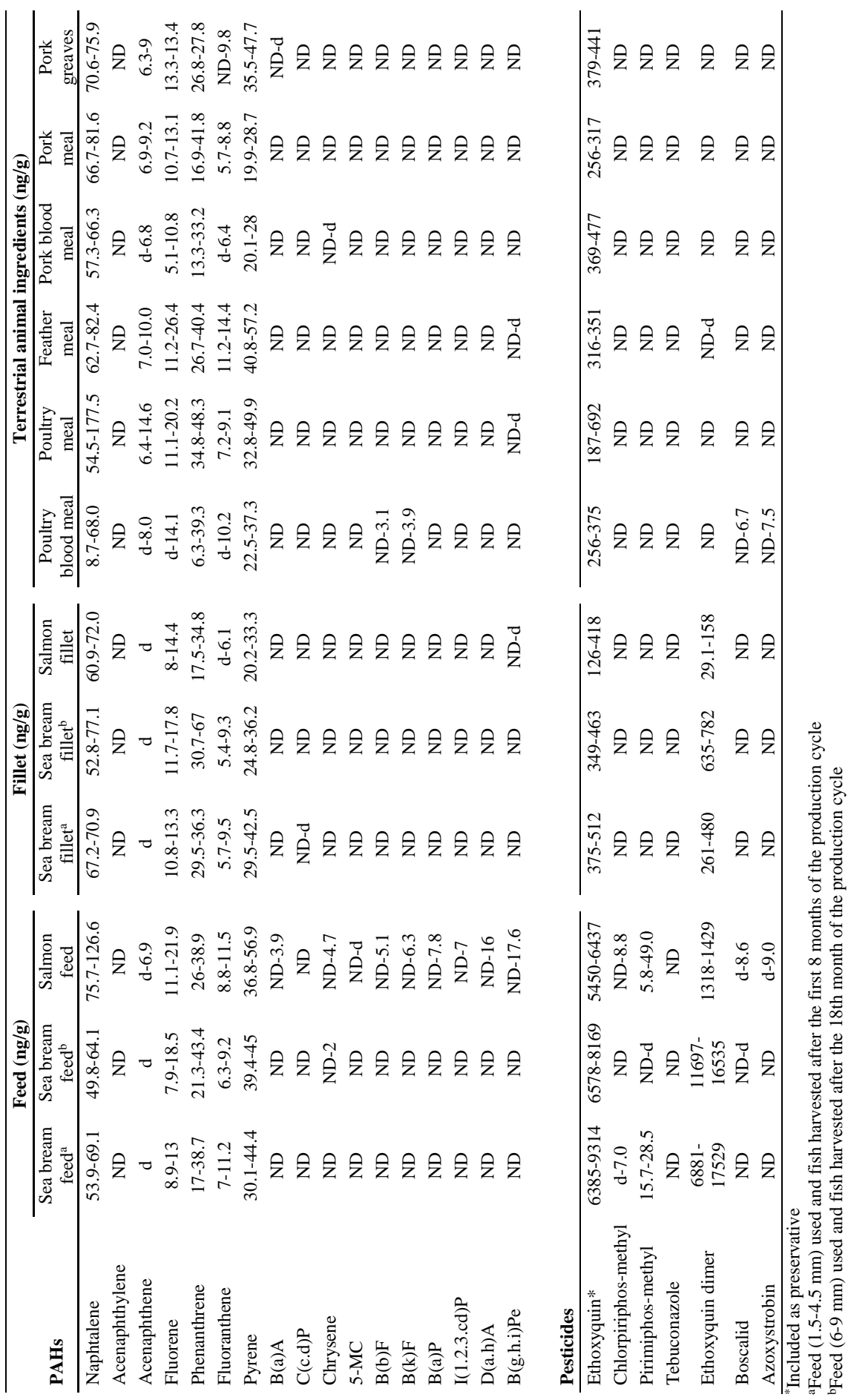




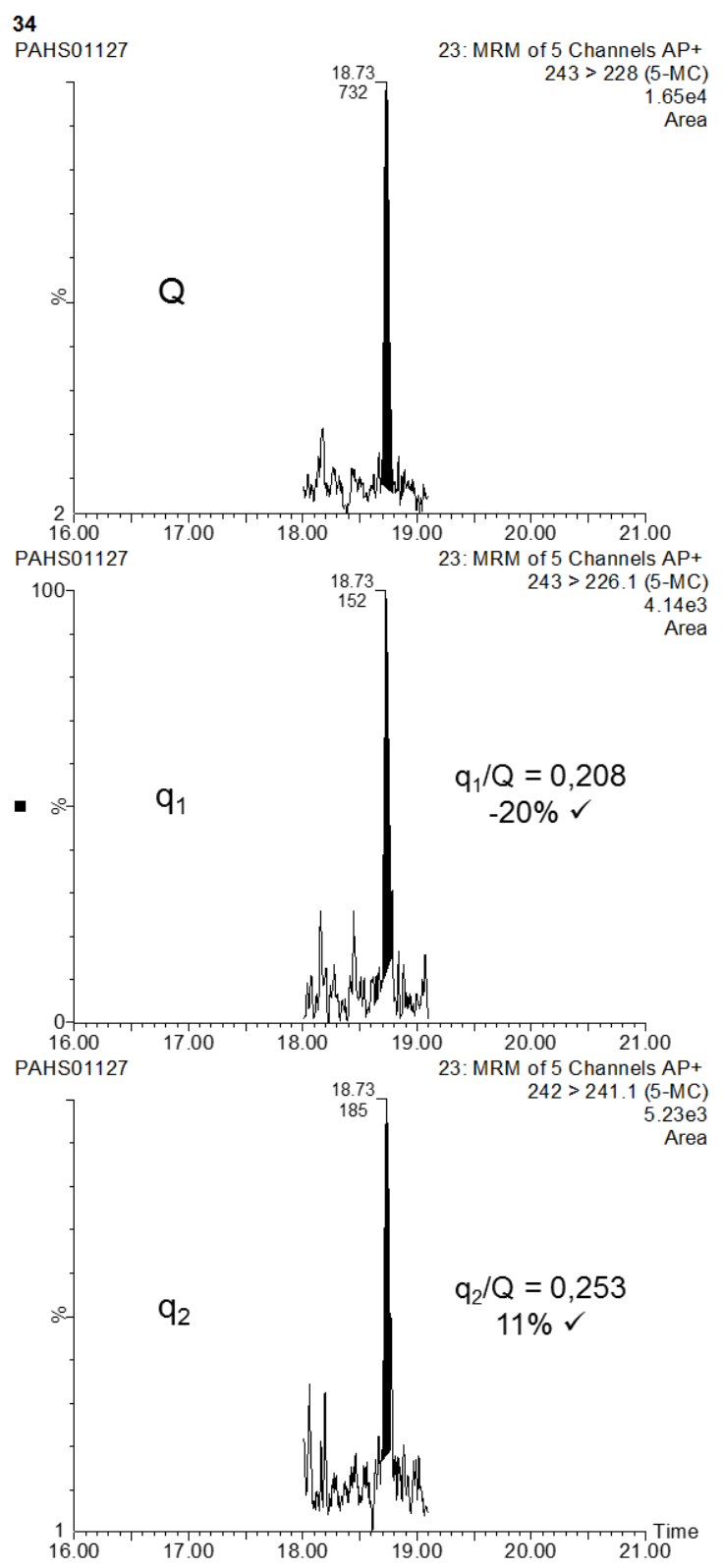

Figure S4. Positive finding of 5-MC in fish meal $\left(<5 \mathrm{ng} \cdot \mathrm{g}^{-1}\right)$ determined and identified by applying GC-APCI-MS/MS in SRM mode. Q: Quantification ion; $\mathrm{q}_{\mathrm{i}}$ : confirmation ion. $\checkmark$, q/Q ratio within tolerance limits; $\times, \mathrm{q} / \mathrm{Q}$ ratio out of tolerance limits. 


\section{Conclusions}

The use of APCI has been evaluated for GC-MS/MS analysis of PAHs. The high sensitivity of this technique allowed the simultaneous quantification of 19 different complex matrices (from aquaculture field) using solvent calibration. The key aspect for this aim was the elimination of matrix effect, without the need of time-consuming purification steps, only by a 20 -fold dilution factor of the final QuEChERs extract, being this aspect a great contribution of the present work. Despite this, LOQs of the developed method were $2 \mathrm{ng} \cdot \mathrm{g}^{-1}$ for most analytes, in the same order or better than those reported in previously published methods for similar matrices [21,22] showing higher efficiency [19]. Also, the use of both $\mathrm{M}^{+\bullet}$ or $[\mathrm{M}+\mathrm{H}]^{+}$gave an additional value to the selectivity in the determination/identification capabilities.

\section{Acknowledgment}

This work has been funded by the EU Seventh Framework Programme ARRAINA Project 288925 (Advanced Research Initiatives for Nutrition and Aquaculture), and the Norwegian Research Council SAFETY-PAP project (227387) from the Sustainable Innovation in Food and Bio-based Industries (Bionær) program. Additional funding was obtained from Generalitat Valenciana (research group of excellence PROMETEOII/2014/085; PROMETEOII/2014/023; ISIC 2012/016). This work has been developed within the framework of the Research Unit of Marine Ecotoxicology (IATS (CSIC)-IUPA (UJI)). We also thank the Spanish Ministry of Economy and Competitiveness and European funding from FEDER program (project AGL2012-37201). 


\section{References}

[1] L. Benedito-Palos, J.C. Navarro, A. Sitjà-Bobadilla, J.G. Bell, S. Kaushik, J. Pérez- Sánchez, High levels of vegetable oils in plant protein-rich diets fed to gilthead sea bream (Sparus aurata L.): growth performance, muscle fatty acid profiles and histological alterations of target tissues, Br. J. Nutr. 100 (2008) 992-1003. http:// dx.doi.org/10.1017/S0007114508966071.

[2] B.E. Torstensen, J.G. Bell, G. Rosenlund, R.J. Henderson, I.E. Graff, D.R. Tocher, et al., Tailoring of Atlantic salmon (Salmo salar L.) flesh lipid composition and sensory quality by replacing fish oil with a vegetable oil blend, J. Agric. Food Chem. 53 (2005) 10166-10178. http://dx.doi.org/ 10.1021/jf051308i.

[3] N.S. Liland, G. Rosenlund, M.H.G. Berntssen, T. Brattelid, L. Madsen, B.E. Torstensen, Net production of Atlantic salmon (FIFO, Fish in Fish out < 1) with dietary plant proteins and vegetable oils, Aquac. Nutr. 19 (2013) 289300. http://dx.doi.org/10.1111/j.1365-2095.2012.00958.x.

[4] A.G.J. Tacon, M. Metian, Feed Matters: satisfying the feed demand of aquaculture, Rev. Fish. Sci. Aquac. 23 (2015) 1-10. http://dx.doi.org/10. 1080/ 23308249.2014.987209.

[5] T. Ytrestøyl, T.S. Aas, T. Åsgård, Utilisation of feed resources in production of Atlantic salmon (Salmo salar) in Norway, Aquaculture 448 (2015) 365-374. http:// dx.doi.org/10.1016/j.aquaculture.2015.06.023.

[6] M. Benísek, L. Bláha, K. Hilscherová, Interference of PAHs and their Nheterocyclic analogs with signaling of retinoids in vitro, Toxicol. Vitr. 22 (2008) 1909-1917. http://dx.doi.org/10.1016/j.tiv.2008.09.009. 
[7] M.J. Dennis, R.C. Massey, G. Cripps, I. Venn, N. Howarth, G. Lee, Factors affecting the polycyclic aromatic hydrocarbon content of cereals, fats and other food products, Food Addit. Contam. 8 (1991) 517-530. http://dx.doi.org/10.1080/ 02652039109374004.

[8] A. Fromberg, A. Højgård, L. Duedahl-Olesen, Analysis of polycyclic aromatic hydrocarbons in vegetable oils combining gel permeation chromatography with solid-phase extraction clean-up, Food Addit. Contam. 24 (2007) 758-767. http:// dx.doi.org/10.1080/02652030601150505.

[9] S. Moret, G. Purcaro, L.S. Conte, Polycyclic aromatic hydrocarbons in vegetable oils from canned foods, Eur. J. Lipid Sci. Technol. 107 (2005) 488496. http:// dx.doi.org/10.1002/ejlt.200501060.

[10] V.H. Teixeira, S. Casal, M.B.P.P. Oliveira, PAHs content in sunflower, soybean and virgin olive oils: evaluation in commercial samples and during refining process, Food Chem. 104 (2007) 106-112. http://dx.doi.org/10.1016 /j.food- chem.2006.11.007.I.

[11] Yebra-Pimentel, R. Fernández-González, E. Martínez Carballo, J. SimalGándara, Searching ingredients polluted by polycyclic aromatic hydrocarbons in feeds due to atmospheric or pyrolytic sources, Food Chem. 135 (2012) 2043-2051. http:// dx.doi.org/10.1016/j.foodchem.2012.06.069.

[12] E.A. Pena, L.M. Ridley, W.R. Murphy, J.R. Sowa, C.S. Bentivegna, Detection of polycyclic aromatic hydrocarbons (PAHs) in raw menhaden fish oil using fluorescence spectroscopy: method development, Environ. Toxicol. Chem. 34 (2015) 1946-1958. http://dx.doi.org/10.1002/etc.3015.

[13] M.H.G. Berntssen, K. Julshamn, A.-K. Lundebye, Chemical 
contaminants in aquafeeds and Atlantic salmon (Salmo salar) following the use of traditional- versus alternative feed ingredients, Chemosphere 78 (2010) 637-646. http://dx.doi.org/ 10.1016/j.chemosphere.2009.12.021.

[14] J. Nácher-Mestre, R. Serrano, L. Benedito-Palos, J.C. Navarro, F.J. López, S. Kaushik, et al., Bioaccumulation of polycyclic aromatic hydrocarbons in gilthead sea bream (Sparus aurata L.) exposed to long term feeding trials with different experimental diets, Arch. Environ. Contam. Toxicol. 59 (2010) 137-146. http:// dx.doi.org/10.1007/s00244-009-9445-1.

[15] EC, Commission regulation (EU) No 835/2011 of 19 August 2011 amendingRegulation (EC) No 1881/2006 as regards maximum levels for polycyclic aromatic hydrocarbons in foodstuffs. Off. J. Eur. Union L215, 4-8., n.d, 2011.

[16] M. Ciecierska, M.W. Obiedziński, Polycyclic aromatic hydrocarbons in vegetable oils from unconventional sources, Food Control. 30 (2013) 556562. http:// dx.doi.org/10.1016/j.foodcont.2012.07.046.

[17] M.D.L. Easton, D. Luszniak, E. Von der Geest, Preliminary examination of contaminant loadings in farmed salmon, wild salmon and commercial salmon feed, Chemosphere 46 (2002) 1053-1074. http://dx.doi.org/10.1016/ S0045-6535(01) 00136-9.

[18] J. Hellou, K. Haya, S. Steller, L. Burridge, Presence and distribution of PAHs, PCBs and DDE in feed and sediments under salmon aquaculture cages in the Bay of Fundy, New Brunswick, Canada, Aquat. Conserv. Mar. Freshw. Ecosyst. 15 (2005) 349-365. http://dx.doi.org/10.1002/aqc.678.

[19] J. Nácher-Mestre, R. Serrano, T. Portolés-Nicolau, F. Hernández, L. 
Benedito- Palos, J. Pérez-Sánchez, A reliable analytical approach based on gas chromatography coupled to triple quadrupole and time-of-flight mass analyzers for the determination and confirmation of polycyclic aromatic hydrocarbons in complex matrices from aquaculture activities, Rapid Commun. Mass Spectrom. 23 (2009) 2075-2086. http://dx.doi.org/10.1002 /rcm.4120.

[20] P. Plaza-Bolaños, A.G. Frenich, J.L.M. Vidal, Polycyclic aromatic hydrocarbons in food and beverages. Analytical methods and trends, J. Chromatogr. A. 1217 (2010) 6303-6326. http://dx.doi.org/10.1016/j.chroma. 2010.07.079.

[21] H. Ziarrusta, M. Olivares, a. Delgado, O. Posada-Ureta, O. Zuloaga, N. Etxebarria, Multiscreening determination of organic pollutants in molluscs using matrix solid phase dispersion, J. Chromatogr. A. 1391 (2014) 18-30. http://dx.doi.org/ 10.1016/j.chroma.2015.02.072.

[22] Y. Sapozhnikova, S.J. Lehotay, Multi-class, multi-residue analysis of pesticides, polychlorinated biphenyls, polycyclic aromatic hydrocarbons, polybrominated diphenyl ethers and novel flame retardants in fish using fast, low-pressure gas chromatography-tandem mass spectrometry, Anal. Chim. Acta 758 (2013) 80-92. http://dx.doi.org/10.1016/j.aca.2012.10.034.

[23] M. Jánská, M. Tomaniová, J. Hajšlová, V. Kocourek, Appraisal of "classic" and "novel" extraction procedure efficiencies for the isolation of polycyclic aromatic hydrocarbons and their derivatives from biotic matrices, Anal. Chim. Acta 520 (2004) 93-103. http://dx.doi.org/10.1016/j.aca. 2004.05.073. 
[24] J. Djinovic, A. Popovic, W. Jira, Polycyclic aromatic hydrocarbons (PAHs) in traditional and industrial smoked beef and pork ham from Serbia, Eur. Food Res.Technol. 227 (2008) 1191-1198. http://dx.doi.org/10.1007/ s00217-008-0836-8.

[25] J. Nácher-Mestre, R. Serrano, T. Portolés, M.H.G. Berntssen, J. PérezSánchez, F. Hernández, Screening of pesticides and polycyclic aromatic hydrocarbons in feeds and fish tissues by gas chromatography coupled to highresolution mass spectrometry using atmospheric pressure chemical ionization, J. Agric. Food Chem. 62 (2014) 2165-2174. http://dx.doi.org/10. 1021/jf405366n.

[26] Y.S. Johnson, Determination of polycyclic aromatic hydrocarbons in edible seafood by QuEChERS-based extraction and gas chromatographytandem mass spectrometry, J. Food Sci. 77 (2012). http://dx.doi.org/10.1111 /j.1750- 3841.2012.02758.x.

[27] L. Cherta, T. Portolés, J. Beltran, E. Pitarch, J.G.J. Mol, F. Hernández, Application of gas chromatography-(triple quadrupole) mass spectrometry with atmospheric pressure chemical ionization for the determination of multiclass pesticides in fruits and vegetables, J. Chromatogr. A. 1314 (2013) 224-240. http://dx.doi.org/ 10.1016/j.chroma.2013.09.029.

[28] M. Raro, T. Portolés, J.V. Sancho, E. Pitarch, F. Hernández, J. Marcos, et al., Mass spectrometric behavior of anabolic androgenic steroids using gas chromatography coupled to atmospheric pressure chemical ionization source. Part I: ionization, J. Mass Spectrom. 49 (2014) 509-521 http://dx.doi.org/ 10.1002/jms.3367. 
[29] T. Portolés, L.E. Rosales, J.V. Sancho, F.J. Santos, E. Moyano, Gas chromatography-tandem mass spectrometry with atmospheric pressure chemical ionization for fluorotelomer alcohols and perfluorinated sulfonamides determination, J. Chromatogr. A. 1413 (2015) 107-116. http://dx.doi.org/10.1016/j.chro- ma.2015.08.016.

[30] T. Portolés, J.G.J. Mol, J.V. Sancho, F. Hernández, Advantages of atmospheric pressure chemical ionization in gas chromatography tandem mass spectrometry: pyrethroid insecticides as a case study, Anal. Chem. 84 (2012) 9802-9810. http:// dx.doi.org/10.1021/ac301699c.

[31] J. Nácher-Mestre, R. Serrano, E. Beltrán, J. Pérez-Sánchez, J. Silva, V. Karalazos, et al., Occurrence and potential transfer of mycotoxins in gilthead sea bream and Atlantic salmon by use of novel alternative feed ingredients, Chemosphere 128 (2015) 314-320. http://dx.doi.org/10.1016/j.chemosphere .2015.02.021.

[32] A.M. Botero-Coy, J.M. Marín, R. Serrano, J.V. Sancho, F. Hernández, Exploring matrix effects in liquid chromatography-tandem mass spectrometry determination of pesticide residues in tropical fruits, Anal. Bioanal. Chem. 407 (2015) 3667-3681. http://dx.doi.org/10.1007/s00216-015-8586-5.

[33] SANTE/11945/2015. Guidance document on analytical quality control and method validation procedures for pesticides residues analysis in food and feed.

[34] T. Portolés, J.G.J. Mol, J.V. Sancho, F. Hernández, Use of electron ionization and atmospheric pressure chemical ionization in gas chromatography coupled to time- of-flight mass spectrometry for screening 
and identification of organic pollutants in waters, J. Chromatogr. A. 1339 (2014) 145-153. http://dx.doi.org/10.1016/ j.chroma.2014.03.001.

[35] T. Portolés, J.V. Sancho, F. Hernández, A. Newton, P. Hancock, Potential of atmospheric pressure chemical ionization source in GC-QTOF MS for pesticide residue analysis, J. Mass Spectrom. 45 (2010) 926-936. http://dx.doi.org/ 10.1002/jms.1784.

[36] K. Ziegenhals, H.-J. Hübschmann, K. Speer, W. Jira, Fast-GC/HRMS to quatify the EU priority PAH, J. Sep. Sci. 31 (2008). http://dx.doi.org/10.1002/ jssc. 200700641.

[37] A.-K. Lundebye, H. Hove, A. Mage, V.J. Bohne, K. Hamre, Levels of synthetic antioxidants (ethoxyquin, butylated hydroxytoluene and butylated hydroxyanisole) in fish feed and commercially farmed fish, Food Addit. Contam. 27 (2010) 1652-1657. 


\subsection{Discusión de los resultados obtenidos}

En el ámbito de la investigación de contaminantes orgánicos resulta de enorme importancia diseñar estrategias analíticas integrales capaces de abordar el análisis de gran variedad de matrices y compuestos de una manera fiable, y lo más económica, simple y verde posible; para dar respuesta a nuevas problemáticas medioambientales. Dada la gran cantidad de contaminantes con propiedades físico-químicas diferentes, resulta interesante desarrollar estrategias como la descrita en este capítulo, que combine LC y GC para abarcar el mayor número de analitos posible.

En primer lugar, y como objetivo principal del artículo científico I, se validó y aplicó un método de screening de pesticidas en ingredientes, piensos y peces de acuicultura mediante GC-APCI-QTOF MS y LC-QTOF MS. Primero, se amplió con 39 nuevos pesticidas el screening por GC-APCI-QTOF MS, validado previamente por Nácher-Mestre et al [15], que contenía 131 pesticidas en las principales matrices de acuicultura. Para ello, al tratarse de una ampliación del método, se analizaron 10 matrices diferentes fortificadas a 0.01 y $0.05 \mathrm{mg} \cdot \mathrm{kg}^{-1}$ con los 170 pesticidas, tanto bajo condiciones de transferencia de carga como de protonación. Siguiendo un criterio del 0\% de falsos negativos, dado el reducido número de QCs, se confirmaron los SDLs de la validación previa y se establecieron SDLs provisionales para los nuevos 39 compuestos. La validación del screening por LC-QTOF MS se llevó a cabo en veinte matrices diferentes para 125 pesticidas siguiendo la máxima de un 5\% de falsos negativos como indica la guía SANCO/12571/2013 [16]. Surgido el interés de incrementar el número de compuestos, esta se amplió en 36 nuevos pesticidas de la misma manera que en la validación por GC. En conjunto, se establecieron SDLs o SDLs provisionales para 207 y 46 
compuestos, respectivamente. A efectos prácticos los SDLs provisionales se trataron como SDLs puramente validados, ya que el criterio que se tomó no permitía ningún falso negativo. Además, un tercio de los nuevos compuestos añadidos a la validación se analizaron mediante las dos técnicas, mejorando así la confianza en la detección.

Tras la validación, ambos métodos de screening se aplicaron en el análisis de muestras reales. El tratamiento de datos se abordó desde las aproximaciones target y suspect screening. Para el tratamiento target, se utilizó una base de datos experimental creada por nuestro grupo de investigación que contenía información cromatográfica i espectrométrica de los compuestos incluidos en la validación. Para la aproximación suspect, se utilizó otra base de datos que únicamente contenía información molecular de contaminantes para los cuales no se disponía de estándares de referencia. Independientemente del modo de tratamiento de los datos, se siguieron los criterios de identificación de la guía SANCO/12571/2013 a excepción de la q/Q ratio, para la cual se adoptó cierta laxitud, ya que la selectividad instrumental del QTOF se consideró suficiente para identificar correctamente los compuestos. De hecho, como puede observarse en la Tabla 1, la última versión de la guía ya no contempla un valor orientativo de q/Q ratio. De los aproximadamente 800 pesticidas incluidos en ambas bases de datos, se detectaron 16 de ellos, 12 de los cuales eran analizables por GC y comprendían 162 de los 167 casos reportados como identificados o detectados.

A fin de confirmar y cuantificar los compuestos detectados e identificados en el screening, se desarrolló y validó un método basado en GC-APCI-MS/MS con analizador QqQ. Además, el método se amplió a PAHs y PCBs debido al interés en su monitorización para evaluar el cambio de los niveles de 
concentración en función de la composición de las dietas.

Tabla 1: Resumen de los criterios de identificación para analizadores HRMS en modo de adquisición full spectrum según las diferentes versiones de la guía SANCO/SANTE.

\begin{tabular}{cccc} 
& SANCO/12571/2013 & SANTE/11945/2015 & SANTE/11813/2017 \\
\hline $\begin{array}{c}\text { Iones } \\
\text { diagnóstico }\end{array}$ & $\begin{array}{c}\text { 2 (incluyendo, al } \\
\text { menos, 1 ion } \\
\text { fragmento) }\end{array}$ & $\begin{array}{c}2 \text { (incluyendo, al } \\
\text { menos, 1 ion } \\
\text { fragmento) }\end{array}$ & $\begin{array}{c}2 \text { (incluyendo, al } \\
\text { menos, 1 ion } \\
\text { fragmento) }\end{array}$ \\
\hline $\begin{array}{c}\text { Exactitud de } \\
\text { masa }\end{array}$ & $<5 \mathrm{ppm}$ & $\leq 5 \mathrm{ppm}$ & $\leq 5 \mathrm{ppm}$ \\
\hline q/Q ratio & $\pm 30 \%$ & $\pm 30 \%$ & $\begin{array}{c}\text { Sin valor orientativo } \\
\text { a }\end{array}$ \\
\hline
\end{tabular}

${ }^{a} \mathrm{La}$ variabilidad de la q/Q ratio no solo se ve afectada por la relación $\mathrm{S} / \mathrm{N}$ de los picos en los XICs, sino que también puede verse afectada por la forma en que se generan los iones fragmento y por la matriz. Debido al valor añadido de la HRMS, las q/Q ratio son menos críticas.

Tras una primera etapa de optimización de las condiciones espectrométricas, se llevó a cabo el estudio de la ionización bajo condiciones de transferencia de carga y de protonación. La mayoría de los compuestos incluidos en el método tendían a la protonación de la molécula, excepto los pesticidas organoclorados y los $\mathrm{PCBs}$, por lo que adquiriendo un compromiso entre sensibilidad y repetitividad de la señal se decidió trabajar en condiciones favorables a este mecanismo de ionización. Además, bajo estas condiciones se observó una mayor selectividad de las transiciones para el C[c,d]P y el $\mathrm{D}(\mathrm{a}, \mathrm{h}) \mathrm{A}$, resolviendo la problemática en el proceso de cuantificación comúnmente reportada en métodos de EI [17]. Relativo a la cromatografía, se decidió utilizar una columna DB-17, de mayor polaridad que la 5-MS utilizada en el screening, para poder separar cromatográficamente el triplete $\mathrm{B}(\mathrm{b}) \mathrm{F}$, B(k)F y B(j)F. Sin embargo, para esta columna se observó una mayor retención de los PAHs menos volátiles, especialmente los dibenzopirenos. Por este motivo, y gracias a la posibilidad de trabajar a flujos más altos en sistemas 
GC-APCI-MS, se estableció una rampa de flujo, manteniendo $2 \mathrm{~mL} \cdot \mathrm{min}^{-1}$ en los dos primeros tercios del cromatograma y subiéndolo a $6 \mathrm{~mL} \cdot \mathrm{min}^{-1}$ en el tercio final, obteniendo así picos cromatográficos más estrechos. Otra problemática que se observó fue la degradación de la columna en la línea de transferencia provocando distorsiones cromatográficas a lo largo de la secuencia (ver figura 1, izquierda). A diferencia de los sistemas de EI, la línea de transferencia en GC-APCI-MS es más larga, lo que puede provocar la degradación de una porción significativa de la columna. Este problema se resolvió utilizando una post-columna desactivada (ver figura 1, derecha).

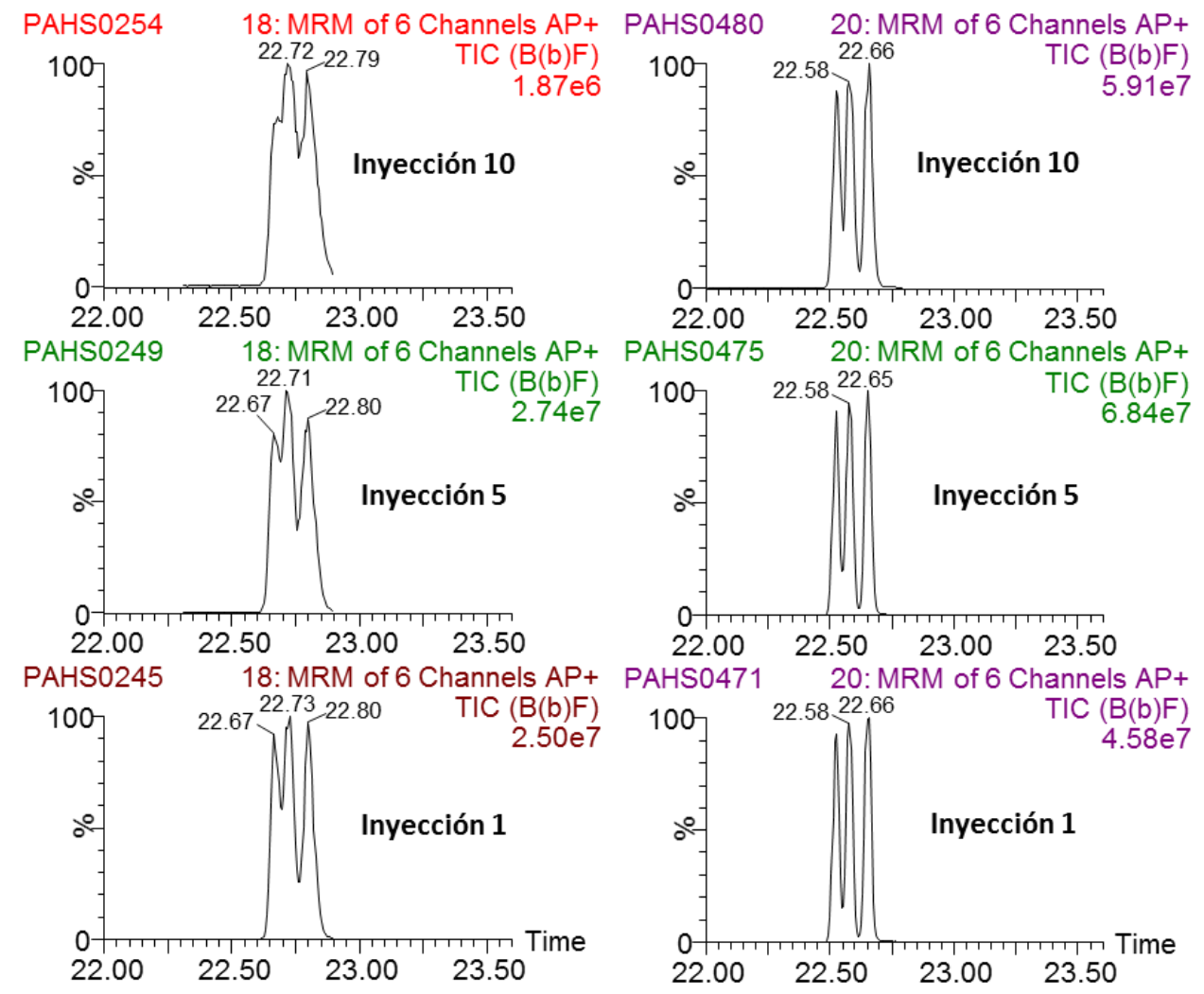

Figura 1: Efecto de la degradación de la columna sobre la resolución cromatográfica del triplete $\mathrm{B}(\mathrm{b}) \mathrm{F}, \mathrm{B}(\mathrm{k}) \mathrm{F}$ y $\mathrm{B}(\mathrm{j}) \mathrm{F}$. A la izquierda, sin postcolumna desactivada; a la derecha, con post-columna desactivada. 
Una vez optimizadas las condiciones cromatográficas, se llevó a cabo el estudio del efecto matriz. Como se ha comentado en la introducción general de la tesis, el efecto matriz en GC se debe principalmente a la interacción de la matriz con los puntos activos del liner y de la columna; y requiere de estrategias de corrección para cuantificar correctamente los analitos. Para este propósito, únicamente se contempló la dilución del extracto final y el uso de SIL-IS, ya que la intención de la estrategia desarrollada era poder utilizar los mismos extractos del screening para su posterior cuantificación. En términos generales, no se observó un efecto matriz significativo en la mayoría de combinaciones matriz/analito para los extractos diluidos 20 veces, lo que dio pie a la cuantificación usando curvas de calibración en solvente relativas a SIL-IS. Este hecho pone en valor el potencial de la fuente APCI y supone un avance en las aplicaciones analíticas en campos como la acuicultura, donde la simplificación del método facilita enormemente el análisis de matrices complejas muy variadas.

Sin embargo, la cuantificación aplicada en este trabajo plantea varias cuestiones. Por un lado, las relacionadas con la corrección del efecto matriz y, por otro, las relacionadas con la corrección de las recuperaciones al utilizar los SIL-IS como surrogate. Idealmente, el uso de SIL-IS para la corrección del efecto matriz requiere que el compuesto a corregir y el compuesto marcado corrector tengan un comportamiento similar en el sistema instrumental. Además, si el SIL-IS se utiliza como surrogate, el compuesto a corregir también se debe comportar idénticamente durante el tratamiento de muestra. No obstante, la situación descrita anteriormente es poco habitual ya que, para que esta ocurra, es prácticamente necesario el uso de SIL-IS de cada 
compuesto nativo incluido en el método, lo que lo hace poco viable económicamente. Así pues ¿sería correcto el uso de un compuesto marcado que no se comporta idénticamente al compuesto que corrige, pero que en términos de recuperación global, es decir, teniendo en cuenta la suma del efecto matriz y del tratamiento de muestra, lo corrige correctamente de manera aparente? A primera vista, parece incorrecto ya que esta corrección podría ser azarosa, es decir, poco robusta y repetible, aplicable únicamente para una matriz homogénea concreta. Pero, ¿y si se valida en diferentes matrices, heterogéneas, y en diferentes días?

Para resolver esta cuestión, se procedió a validar el método. Debido a la gran cantidad de matrices diferentes a analizar, se decidió validarlo siguiendo los criterios de la guía SANTE/11945/2015 [18], a 2 y 50 ng·g-1 ${ }^{-1}$ en salmón y dorada. La decisión de utilizar solo estas dos matrices se fundamentó en el hecho de ser representativas de los productos finales del proceso de producción acuícola. El resto de matrices fueron validadas mediante QCs individuales a 5 y $50 \mathrm{ng} \cdot \mathrm{g}^{-1}$ inyectados en cada secuencia. El método cumplió los requisitos de validación en salmón y dorada para la mayoría de compuestos a ambos niveles. Referente a los QCs individuales, la tabla 2 resume el total de QCs inyectados en función de su clasificación según la guía SANTE/11945/2015 [18]. Como puede observarse, pese a la gran variedad de matrices analizadas, el método se mostró adecuado para la mayoría de compuestos, demostrando, además, la robustez del uso de señales relativas a los SIL-IS para su cuantificación.

Finalmente, el método se aplicó al análisis de las muestras. Por lo que respeta al índice de falsos positivos reportados en el método de screening, todos los compuestos identificados se confirmaron por GC-APCI-MS/MS, excepto 5 
casos que no se pudieron confirmar por incompatibilidad cromatográfica o inadecuación del método. Además, cabe destacar que de los 37 casos reportados como "detectados" se confirmó la identidad de 22 de ellos. Únicamente 4 de los detectados por LC no se pudieron identificar por incompatibilidad con la cromatografía. Referente a los falsos negativos, gracias a la mayor sensibilidad del acoplamiento GC-APCI-MS/MS se reportaron 47 nuevos positivos, todos ellos a concentraciones inferiores a los SDL de los compuestos detectados en el screening. Así pues, la estrategia desarrollada demostró ser adecuada y de gran utilidad para el análisis de muestras de acuicultura. 


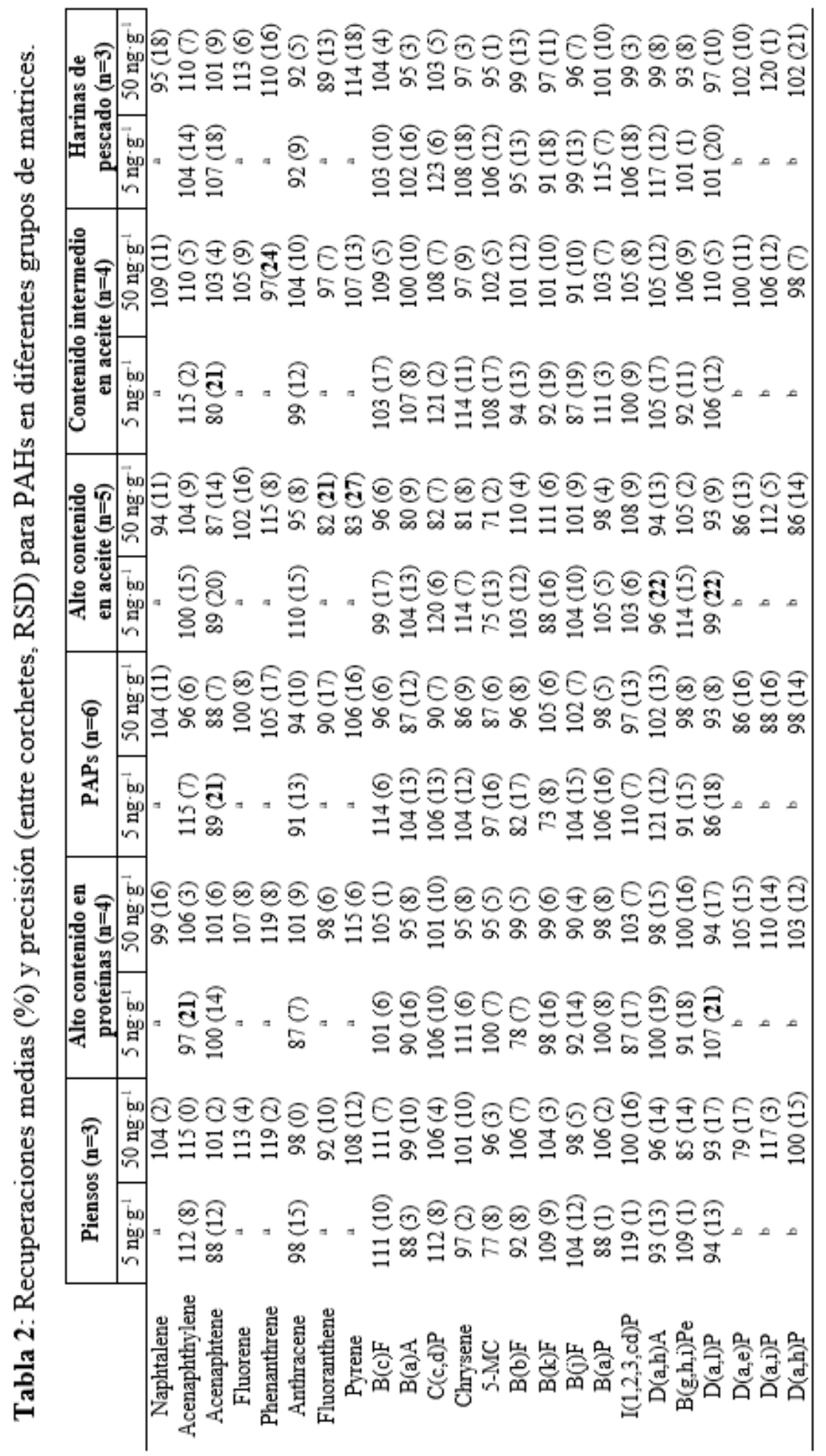




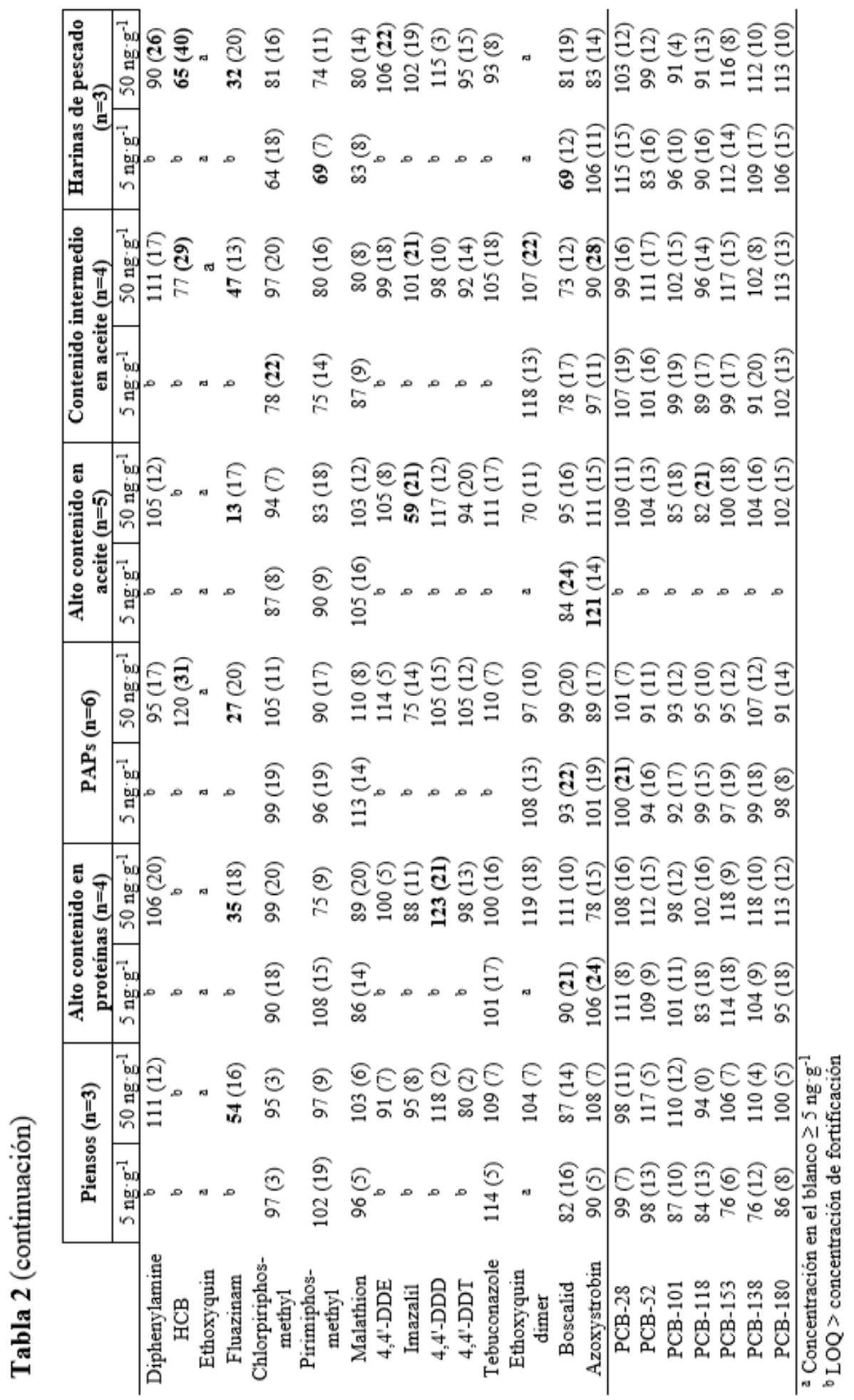





\subsection{Referencias}

1. Berntssen MHG, Olsvik PA, Torstensen BE, Julshamn K, Midtun T, Goksøyr A, Johansen J, Sigholt T, Joerum N, Jakobsen J V., Lundebye AK, Lock EJ (2010) Reducing persistent organic pollutants while maintaining long chain omega-3 fatty acid in farmed Atlantic salmon using decontaminated fish oils for an entire production cycle. Chemosphere 81:242-252. doi: 10.1016/j.chemosphere.2010.06.031

2. Nácher-Mestre J, Serrano R, Benedito-Palos L, Navarro JC, López FJ, Pérez-Sánchez J (2009) Effects of fish oil replacement and re-feeding on the bioaccumulation of organochlorine compounds in gilthead sea bream (Sparus aurata L.) of market size. Chemosphere 76:811-817. doi: 10.1016/j.chemosphere.2009.04.046

3. Berntssen MHG, Julshamn K, Lundebye A-K (2010) Chemical contaminants in aquafeeds and Atlantic salmon (Salmo salar) following the use of traditional- versus alternative feed ingredients. Chemosphere 78:637-646. doi: 10.1016/j.chemosphere.2009.12.021

4. Nácher-Mestre J, Serrano R, Portolés T, Berntssen MHG, PérezSánchez J, Hernández F (2014) Screening of pesticides and polycyclic aromatic hydrocarbons in feeds and fish tissues by gas chromatography coupled to high-resolution mass spectrometry using atmospheric pressure chemical ionization. J Agric Food Chem 62:2165-74. doi: 10.1021/jf405366n

5. Nácher-Mestre J, Serrano R, Benedito-Palos L, Navarro JC, López FJ, Kaushik S, Pérez-Sánchez J (2010) Bioaccumulation of polycyclic 
aromatic hydrocarbons in gilthead sea bream (Sparus aurata L.) exposed to long term feeding trials with different experimental diets. Arch Environ Contam Toxicol 59:137-146. doi: 10.1007/s00244-0099445-1

6. $\quad$ FAO (2018) El estado mundial de la pesca y la acuicultura 2018. Cumplir los objetivos de desarrollo sostenible. Roma. Licencia: CC BY-NC-SA 3.0 IGO

7. Hernández F, Pozo OJ, Sancho J V., Bijlsma L, Barreda M, Pitarch E (2006) Multiresidue liquid chromatography tandem mass spectrometry determination of 52 non gas chromatography-amenable pesticides and metabolites in different food commodities. Journal of Chromatography A

8. Moreno JLF, Frenich AG, Bolaños PP, Vidal JLM (2008) Multiresidue method for the analysis of more than 140 pesticide residues in fruits and vegetables by gas chromatography coupled to triple quadrupole mass spectrometry. J Mass Spectrom. doi: 10.1002/jms.1400

9. Careri M, Bianchi F, Corradini C (2002) Recent advances in the application of mass spectrometry in food-related analysis. J. Chromatogr. A

10. Sapozhnikova Y, Lehotay SJ (2013) Multi-class, multi-residue analysis of pesticides, polychlorinated biphenyls, polycyclic aromatic hydrocarbons, polybrominated diphenyl ethers and novel flame retardants in fish using fast, low-pressure gas chromatography-tandem mass spectrometry. Anal Chim Acta 758:80-92. doi: 
10.1016/j.aca.2012.10.034

11. Comisión Europea (2002) Decisión de la Comisión Europea 2002/657/CE, por la que se aplica la Directiva 96/23/CE del Consejo en cuanto al funcionamiento de los métodos analíticos y la interpretación de los resultados. D Of las Comunidades Eur 29. doi: 10.7326/L14-5033

12. SANTE/11813/2017 (2017) Guidance document on analytical quality control and validation procedures for pesticide residues analysis in food and feed. Eur Comm Heal Consum Prot Dir 2-44. doi: 10.13140/RG.2.2.33021.77283

13. Hernández F, Ibáñez M, Portolés T, Cervera MI, Sancho J V., López FJ (2014) Advancing Towards Universal Screening for Organic Pollutants in Waters. J Hazard Mater 282:86-95. doi: 10.1016/j.jhazmat.2014.08.006

14. Lehotay SJ, Sapozhnikova Y, Mol HGJ (2015) Current issues involving screening and identification of chemical contaminants in foods by mass spectrometry. TrAC - Trends Anal Chem 69:62-75. doi: 10.1016/j.trac.2015.02.012

15. Nácher-Mestre J, Serrano R, Portolés T, Berntssen MHG, PérezSánchez J, Hernández F (2014) Screening of pesticides and polycyclic aromatic hydrocarbons in feeds and fish tissues by gas chromatography coupled to high-resolution mass spectrometry using atmospheric pressure chemical ionization. J Agric Food Chem 62:2165-2174. doi: 10.1021/jf405366n 
16. European Commission (2014) Analytical quality control and method validation procedures for pesticide residues analysis in food and feed; document no. SANCO/12571/2013

17. Veyrand B, Brosseaud A, Sarcher L, Varlet V, Monteau F, Marchand P, Andre F, Le Bizec B (2007) Innovative method for determination of 19 polycyclic aromatic hydrocarbons in food and oil samples using gas chromatography coupled to tandem mass spectrometry based on an isotope dilution approach. J Chromatogr A 1149:333-344. doi: 10.1016/j.chroma.2007.03.043

18. European Commission (2015) Analytical quality control and method validation procedures for pesticide residues analysis in food and feed; document no. SANTE/11945/2015 


\section{CAPÍTULO 3}

\section{ESTUDIO DE LA TRANSFERENCIA}

\section{DE CONTAMINANTES ORGÁNICOS}

A TRAVÉS DE LA DIETA EN

SALMÓN ATLÁNTICO MEDIANTE CROMATOGRAFÍA DE LÍQUIDOS ACOPLADA A ESPECTROMETRÍA DE MASAS EN TÁNDEM 

CAPÍtUlO 3: ESTUDIO DE LA TRANSFERENCIA DE CONTAMINANTES ORGÁNICOS A TRAVÉS DE LA DIETA EN SALMÓN ATLÁNTICO MEDIANTE CROMATOGRAFÍA DE LÍQUIDOS ACOPLADA A ESPECTROMETRÍA DE MASAS EN TÁNDEM

\subsection{Introducción}

3.2. Artículo científico III

"LC-MS/MS method for the determination of organophosphorus pesticides and their metabolites in salmon and zebrafish fed with plant-based feed ingredients"

Analytical and Bioanalytical Chemistry, 2017.

3.3. Discusión de los resultados obtenidos

3.4. Referencias 



\subsection{Introducción}

Ante el nuevo escenario generado en el ámbito de la acuicultura en relación a la composición de los piensos, los trabajos expuestos en el capítulo 2 de la presente tesis confirmaron la tendencia descrita en estudios anteriores $[1,2]$, reportando PAHs y pesticidas como los principales contaminantes orgánicos presentes en ingredientes vegetales y piensos, si bien la transferencia a la parte comestible del pescado era baja o no detectable. De los aproximadamente 800 pesticidas incluidos en las bases de datos para realizar el screening del artículo científico I, el pirimiphos-methyl y el chlorpyrifos-methyl fueron los principales principios activos detectados en ingredientes vegetales y piensos. De hecho, el 100\% de los piensos contenían pirimiphos-methyl.

Pese a estar regulados por la UE en la mayoría de productos alimenticios, sus MRLs en pescado, piensos e ingredientes de acuicultura son aún inexistentes, por lo que resulta imprescindible conocer el efecto de estos y de sus metabolitos en peces de cría para establecer límites apropiados que garanticen la salud de los peces y la seguridad alimentaria al consumidor. De hecho, el informe elaborado por la UE "Draft Renewal Assessment Report prepared according to the Commission Regulation (EU) N ${ }^{\circ} 1107 / 2009$ " de septiembre de 2017 sobre el pirimiphos-methyl [3], no dispone de información sobre metabolismo y estudios de alimentación para peces, mientras que sí está disponible para rumiantes, cerdos y aves de corral. Así pues, fruto de los resultados extraídos de proyectos como ARRAINA y la falta de conocimiento sobre la transferencia de pesticidas del pienso al pescado [4], en el año 2016 se inició el proyecto "AQUASAFE (254807)": un proyecto multidisciplinar que pretende contribuir a la regulación del pirimiphos-methyl mediante su evaluación toxicológica in vitro e in vivo en salmón atlántico. 
En el ámbito de la toxicología, la química analítica juega un papel fundamental, especialmente en los experimentos de exposición in vivo. Estos requieren de métodos analíticos sensibles y fiables que permitan detectar compuestos activos y sus metabolitos a bajas concentraciones en matrices habitualmente complejas para, así, generar datos que permitan crear modelos toxicológicos de bioacumulación y eliminación. Los metabolitos pueden presentar una toxicidad semejante al compuesto activo y pueden contribuir a la toxicidad general, razón por la cual se recomienda su análisis [5]. Además, también pueden tener propiedades físico-químicas muy diferentes al compuesto precursor aunque, por lo general, suelen ser más polares. Por este motivo, la técnica analítica ampliamente usada para su determinación es la LC.

En el presente capítulo se discute el desarrollo, validación y aplicación de un método analítico basado en el acoplamiento LC-MS/MS con analizador QqQ para la determinación de chlorpyrifos-methyl, pirimiphos-methyl y sus principales metabolitos en muestras de pez cebra y diferentes tejidos de salmón. El trabajo descrito en el artículo científico III se presenta como una herramienta para evaluar la cinética de bioacumulación y eliminación del pirimiphos-methyl que contribuye a ampliar el conocimiento sobre el comportamiento de este principio activo en salmón sometido a una exposición dietaria prolongada.

El trabajo realizado en este capítulo se ha desarrollado en el marco del proyecto AQUASAFE (Evaluation of contaminant interactions using integrative high-throughput technology for aquafeed safety). 


\title{
3.2. Artículo científico III
}

Analytical and Bioanalytical Chemistry (2019)

\section{LC-MS/MS method for the determination of organophosphorus pesticides and their metabolites in salmon and zebrafish fed with plant- based feed ingredients}

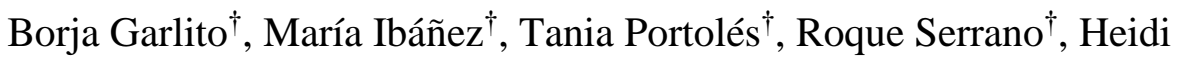
Amlund $^{\#}$, Anne-Katrine Lundebye ${ }^{\S}$, Monica Sanden ${ }^{\S}$, Marc H.G. Berntssen $^{\S *}$, Félix Hernández ${ }^{\dagger *}$

${ }^{\dagger}$ Research Institute for Pesticides and Water (IUPA), Avda. Sos Baynat, s/n, University Jaume I, 12071 Castellón, Spain

\# Technical University of Denmark (DTU), Anker Engelunds Vej 1, 2800 Kgs. Lyngby, Denmark

$\S$ National Institute of Nutrition and Seafood Research, PO Box 2029 Nordnes, N-5817 Bergen, Norway

\begin{abstract}
The composition of Atlantic salmon feed has changed considerably over the last two decades from being marine-based (fishmeal and fish oil) to mainly containing plant ingredients. Consequently, concern related to traditional persistent contaminants typically associated with fish-based feed has been replaced by other potential contaminants not previously associated with salmon farming. This is the case for many pesticides, which are used worldwide to increase food production, and may be present in plant ingredients. Earlier studies have identified two organophosphorus pesticides,
\end{abstract}


chlorpyrifos-methyl and pirimiphos-methyl, in plant ingredients used for aquafeed production. In the present study, we developed a reliable and sensitive analytical method, based on liquid chromatography coupled to tandem mass spectrometry, for the determination of these pesticides and their main metabolites in warm-water (zebrafish) and cold-water (Atlantic salmon) species, where possible differences in metabolites could be expected. The method was tested in whole zebrafish and in different salmon tissues, such as muscle, bile, kidney, fat and liver. The final objective of this work was to assess kinetics of chlorpyrifos-methyl and pirimiphos-methyl and their main metabolites in fish tissue, in order to fill the knowledge gaps on these metabolites in fish tissues when fed over prolonged time.

\section{Keywords}

Chlorpyrifos-methyl; Pirimiphos-methyl; Metabolites; Atlantic salmon, Zebrafish; LC-MS/MS 


\section{Introduction}

Plant ingredients are the main substitutes for fish oil and fishmeal and currently typically constitute about $70 \%$ of the ingredients in commercial salmon feed in Norway $(1,2)$. The use of plant ingredients, together with commercial decontamination techniques, decreases the content of persistent organic pollutants (POPs) traditionally associated with fish oil and other marine ingredients $(3,4)$. However, plant ingredients may introduce novel contaminants not previously associated with salmon farming (4). Among them, pesticides are the group of major concern (5). Earlier studies in the EU projects "AQUAMAX" and "ARRAINA" identified novel feed contaminants, such as polyaromatic hydrocarbons (PAHs), mycotoxins and none organochlorine pesticides (OCP) in plant ingredients and fish feed with low or non-detectable transfer of the parent compounds to the edible part of the fish $(4,5)$.

Until recently, research has focused on the analysis of organochlorine compounds in fish, and less information has been available concerning other groups of pesticides. In the last five years the number of scientific articles related to pesticides in fish matrices has notably increased reflecting growing concern regarding these contaminants (6-8). Most recent literature dealing with pesticide residue analysis is based on the use of liquid chromatography (LC) coupled to tandem mass spectrometry (MS/MS) with triple quadrupole (QqQ) (6-10). This technique is applicable for currently used pesticides, mostly polar in nature, and is especially suitable for metabolites and transformation products (TPs), which are usually more polar than the parent compound. LC-MS/MS is a powerful technique in this field due to its excellent sensitivity and selectivity, as well as robustness and less sample treatment 
required (e.g. in comparison with GC-MS methods).

Our previous work indicated that from all new compounds screened, pesticides were the major contaminants present in novel fish feed (11). Among more than 400 pesticides investigated, chlorpyrifos-methyl and pirimiphosmethyl were found in several vegetable feed ingredients as well as in salmon feed. Further surveillance of commercially produced Norwegian salmon feed and feed ingredients showed that $55 \%$ of the analyzed rapeseed oils contained pirimiphos-methyl. For most food products, maximum residue levels (MRLs) for none OCP pesticides have been established in the EU; however, no specific MRLs have been defined yet for fish or seafood and default precautionary MRLs are currently applied. Knowledge on the effect of dietary plant-derived pesticides and their metabolites in Atlantic salmon (Salmo salar) is needed to set appropriate limits for pesticides to ensure good fish health and food safety.

In a benefit-risk assessment of fish and fish products, it was highlighted that knowledge on the feed-to-fillet transfer of plant-derived pesticides from feed to fish is lacking (12). With regards to chlorpyrifos-methyl and pirimiphosmethyl, one might expect that bioavailability and accumulation are high due to their lipophilic nature and relatively small molecular size. Bioaccumulation of chlorpyrifos-ethyl has been reported in body, head and viscera of tilapia (Oreochromis mossambicus) (13). However, biotransformation may be crucial in the process of accumulation of the parent compound. Particularly, for non-persistent pesticides metabolism plays an important role in the bioavailability and potential transfer to edible parts of fish. It is known that 3,5,6-trichloropyridinol (TCP free and conjugated) is the major metabolite of both chlorpyrifos-ethyl and chlorpyrifos-methyl in products of animal and plant origin $(14,15)$, while pirimiphos-methyl is mainly metabolized into 2- 
(diethylamino)-6-methyl-4-pyrimidinol (2-DAMP), O-[2-(ethylamino)-6methylpyrimidin-4-yl]O,O-dimethylphosphorothioate (N-Des-PM) and 2amino-6-methyl-4-pyrimidinol (2-AMP). The first two metabolites are considered of toxicological significance by the European Food Safety Authority (EFSA) (16).

In the project "Aquasafe" the main objective was to investigate the bioaccumulation, biotransformation and elimination kinetics of dietary chlorpyrifos-methyl and pirimiphos-methyl in whole zebrafish (Danio rerio) and Atlantic salmon tissues. For this purpose, the present study is aimed to develop a modern, fast and sensitive analytical method, based on LC-MS/MS with QqQ, for the quantification of these two pesticides and their main metabolites in zebrafish, and also in salmon muscle, bile, kidney, fat and liver.

\section{Materials and methods}

\subsection{Chemicals and reagents}

Pirimiphos-methyl (PM), chlorpyrifos-methyl (CLP-M), 3,5,6-trichloro-2pyridinol (TCP), chlorpyrifos-methyl-oxon (CLP-M-oxon), N-desethylpirimiphos-methyl (N-Deset-PM) and 2-diethylamino-6-methyl-4pyrimidinol (2-DAMP) were purchased from Sigma-Aldrich (Pestanal ® analytical standard, St Louis, MO, USA). Stock standard solutions (around $500 \mathrm{mg} \cdot \mathrm{L}^{-1}$ ) were prepared in acetone. Working standard solutions containing all compounds were prepared by dilution of mixtures with acetonitrile. Both stock standard solutions and working solutions were stored in a freezer at -27 ${ }^{\circ} \mathrm{C}$.

B. Garlito et al., Anal. Bioanal. Chem (2019) 
Stable Isotopic Labelled Internal Standards (SIL-IS) CLP-M D 6 , PM D6 and ${ }^{T C P}{ }^{13} \mathrm{C}_{3}$ were purchased from Dr. Ehrenstorfer (Augsburg, Germany).

HPLC-grade water was obtained from water passed through a Milli-Q water purification system (Millipore LTD, Bedford, MA, USA). LC-MS grade acetonitrile $(\mathrm{ACN})$ and methanol $(\mathrm{MeOH})$, residue analysis grade acetone, extra pure anhydrous magnesium sulphate $\left(\mathrm{MgSO}_{4}\right)$, sodium hydroxyde and LC-MS grade formic acid (FA) were obtained from Scharlau (Barcelona, Spain). $\mathrm{MgSO}_{4}$ was dried overnight at $300^{\circ} \mathrm{C}$ before its use. Leucine enkephaline was provided by Sigma-Aldrich.

\subsection{Instrumentation}

\section{UHPLC-MS/MS.}

A UPLC ${ }^{\mathrm{TM}}$ system (Acquity, Waters, Milford, MA, USA) was interfaced to a triple quadrupole mass spectrometer (Xevo TQ-S, Waters Corporation, Manchester, UK). LC separation was performed with a $50 \times 2.1 \mathrm{~mm}, 1.7 \mu \mathrm{m}$ particle size Acquity UPLC BEH $\mathrm{C}_{18}$ analytical column (Waters). The mobile phases employed consisted on water (A) and acetonitrile (B) both with $0.0025 \% \mathrm{HCOOH}$, at a flow rate of $0.3 \mathrm{~mL} \cdot \mathrm{min}^{-1}$. The gradient program started with $50 \%$ B, increased linearly to $90 \%$ of B for 1.5 min and maintained during $1.5 \mathrm{~min}$. Finally the gradient was held to initial conditions in order to re-equilibrate the column. Temperature column was set to $25^{\circ} \mathrm{C} .2 \mu \mathrm{L}$ were selected as injection volume.

In the Selected Reaction Monitoring (SRM) method applied, dwell time values ranging from 5 to $90 \mathrm{~ms}$ were used in order to obtain 12 points per 
peak. Source temperature was set to $150^{\circ} \mathrm{C}$. Drying and nebulising gas was nitrogen (Praxair, Valencia, Spain). Desolvation gas flow was set to $1200 \mathrm{~L} \cdot \mathrm{h}^{-}$ ${ }^{1}$ and the cone gas to $250 \mathrm{~L} \cdot \mathrm{h}^{-1}$. For operating in MS/MS mode, argon (99.995\%; Praxair, Valencia, Spain) was used as collision gas at $0.25 \mathrm{~mL} \cdot \mathrm{min}^{-}$ 1). Capillary voltage and desolvation gas temperature were set at $3.2 \mathrm{kV}$ (1.9 $\mathrm{kV}$ in $\mathrm{ESI}^{-}$mode) and $650^{\circ} \mathrm{C}$ respectively. TargetLynx (MassLynx v. 4.1, Waters, Manchester, UK) software was used to process the quantitative data.

\section{UHPLC-(Q)TOF MS.}

UHPLC-(Q)TOF MS analysis was performed following the conditions used by Portolés et al. [42]. A UPLC ${ }^{\mathrm{TM}}$ system (Acquity, Waters) was coupled to a hybrid QTOF mass spectrometer (XEVO G2, Waters Micromass, Manchester, UK) with an orthogonal Z-spray electrospray ionization interface. The chromatographic separation was performed using a Cortecs C18 (Waters) $(100 \times 2.1 \mathrm{~mm}, 2.7 \mu \mathrm{m})$ analytical column at a flow rate of $0.3 \mathrm{~mL} \cdot \mathrm{min}^{-1}$. The column temperature was set to $40^{\circ} \mathrm{C}$. The mobile phases used were $\mathrm{H}_{2} \mathrm{O}$ with $0.01 \% \mathrm{HCOOH}(\mathrm{A})$ and $\mathrm{MeOH}$ with $0.01 \% \mathrm{HCOOH}(\mathrm{B})$ performing a phase gradient as follows: $10 \%$ of B at 0 min, $90 \%$ of B at 14 min linearly increased, $90 \%$ of B at 16 min, and finally $10 \% \mathrm{~B}$ at $18 \mathrm{~min}$ to return to initial conditions. The injection volume was $20 \mu \mathrm{L}$.

For $\mathrm{MS}^{\mathrm{E}}$ experiments, two acquisition functions with different collision energies were created and applied sequentialy in each sample injection: the low energy function (LE), selecting a collision energy of $4 \mathrm{eV}$, and the second one, the high energy function (HE), with a collision energy ramp ranging from 15 to $40 \mathrm{eV}$. The TOF resolution was 20.000 at FWHM at $m / z$ 556,2771. 


\subsection{Samples}

Muscle, liver, kidney, bile and fat tissue samples were obtained from seawater adapted Atlantic salmon, that was fed with pirimiphos-methyl spiked diets to a level of $15.2 \mathrm{mg} \cdot \mathrm{kg}^{-1}$ for 81 days. The pirimiphos-methyl was vacuum top coated to commercially produced (Skretting ARC, Stavanger, Norway) salmon feed pellets with $2 \%$ fish oil at an ambient temperature of $15^{\circ} \mathrm{C}$. No pirimiphos-methyl was detected in the unspiked feed pellets. Post-smolt Atlantic salmon (Salmo salar L.) of both genders (SalmoBreed strain) were distributed among fifteen flow-through fiberglass tanks $(100 \mathrm{~L} ; 0.80 \mathrm{~m} \times 0.95 \mathrm{~m}$ $\mathrm{x} 0.5 \mathrm{~m}$ ). Initial weight and length (fork-tail) were respectively $132 \pm 25 \mathrm{~g}$ and $18 \pm 2 \mathrm{~cm}$ (mean \pm standard deviation; $n=375$ ). The experiment complied with the guidelines of the Norwegian Regulation on Animal Experimentation and EC Directive 86/609/EEC. The experiment was ethically approved by the Norwegian Animal Research Authority (now the Norwegian Food Safety Authority; approval number 12091) and performed according to national and international ethical standards.

\subsection{Sample treatment}

$\underline{\text { LC-QTOF MS screening of salmon liver, kidney and muscle }}$

For each matrix, a control sample (not exposed to contaminants) and the most exposed one to contaminated diets were subjected to a screening analysis, in order to identify potential metabolites of the pesticides under study To this aim, $1 \mathrm{~g}$ of muscle ( $0.5 \mathrm{~g}$ for liver and kidney) was accurately weighed into a $15 \mathrm{~mL}$ Falcon tube and $2 \mathrm{~mL}$ of ACN:acetone (80:20) with $1 \% \mathrm{HCOOH}(1$ $\mathrm{mL}$ in the case of liver and kidney) was added, and the tube was vigorously shaken by Vortex for $1 \mathrm{~min}$. After that, $0.5 \mathrm{~g}$ of $\mathrm{MgSO}_{4}$ per gram of sample

B. Garlito et al., Anal. Bioanal. Chem (2019) 
were added and the tube was immediately shaken for $1 \mathrm{~min}$. Subsequently, the tube was centrifuged at $6,000 \mathrm{rcf}$ for $5 \mathrm{~min}$, and $200 \mu \mathrm{L}$ of the supernatant were evaporated to dryness at $30^{\circ} \mathrm{C}$ under a gentle stream of nitrogen. The residue was dissolved in $200 \mu \mathrm{L}$ of water and filtered through $0.45 \mu \mathrm{m}$ nylon filters (Phenomenex, Torrance, CA, USA). Finally, $20 \mu \mathrm{L}$ of the extract was injected into the LC-QTOF MS system.

\section{$\underline{\text { LC-MS/MS QqQ analysis (see Figure 1A) }}$}

For LC-MS/MS analysis, $1 \mathrm{~g}$ of zebrafish or salmon muscle $(0.5 \mathrm{~g}$ for liver and kidney, and $0.1 \mathrm{~g}$ for fat) was accurately weighed into a $15 \mathrm{~mL}$ Falcon tube ( $2 \mathrm{~mL}$ Eppendorf tube for fat). Then, $2 \mathrm{~mL}$ per gram of ACN:acetone (80:20) with $1 \% \mathrm{HCOOH}$ were added for zebrafish, muscle, liver and kidney ( $5 \mathrm{~mL}$ per gram for fat), and the tube was vigorously shaken by Vortex for 1 min. After that, $0.5 \mathrm{~g}$ of $\mathrm{MgSO}_{4}$ per gram of sample was added and the tube was immediately shaken for $1 \mathrm{~min}$. Subsequently, the tube was centrifuged at $6000 \mathrm{rcf}$ for $5 \mathrm{~min}$ and $100 \mu \mathrm{L}$ of the supernatant was diluted with $800 \mu \mathrm{L}$ of water and $100 \mu \mathrm{L}$ of $25 \mathrm{ng} \cdot \mathrm{mL}^{-1}$ SIL-IS solution. Finally, the diluted extracts were filtered through $0.45 \mu \mathrm{m}$ nylon filters and $2 \mu \mathrm{L}$ were injected into the LC-MS/MS system.

For the analysis of bile samples, $400 \mu \mathrm{L}$ of $\mathrm{ACN}$ :acetone (80:20) with $1 \%$ $\mathrm{HCOOH}$ were added to $100 \mu \mathrm{L}$ of bile in a $2 \mathrm{~mL}$ Eppendorf tube. The tube was shaken by Vortex for $1 \mathrm{~min}$ and centrifruged at $12600 \mathrm{rcf}$ for $5 \mathrm{~min}$. Then, $250 \mu \mathrm{L}$ of the extract were 4 -fold diluted with $650 \mu \mathrm{L}$ of water and $100 \mu \mathrm{L}$ of $25 \mathrm{ng} \cdot \mathrm{mL}^{-1}$ SIL-IS solution. Finally, the diluted extract was filtered through $0.45 \mu \mathrm{m}$ nylon filters and $2 \mu \mathrm{L}$ were injected into the LC-MS/MS system. 
The procedure for feed samples was as follows: $1 \mathrm{~g}$ of feed was accurately weighed into a $15 \mathrm{~mL}$ Falcon tube. Then, $10 \mathrm{~mL}$ of ACN:acetone (80:20) with $1 \% \mathrm{HCOOH}$ were added and the tube was vigorously shaken by Vortex for 1 min. After that, $0.5 \mathrm{~g}$ of $\mathrm{MgSO}_{4}$ was added and the tube was immediately shaken for $1 \mathrm{~min}$. Subsequently, the tube was centrifuged at $6000 \mathrm{rcf}$ for 5 $\min .20 \mu \mathrm{L}$ of the supernatant were diluted with $880 \mu \mathrm{L}$ of water and $100 \mu \mathrm{L}$ of $25 \mathrm{ng} \cdot \mathrm{mL}^{-1}$ SIL-IS solution. Finally, the diluted extracts were filtered through $0.45 \mu \mathrm{m}$ nylon filters and $2 \mu \mathrm{L}$ were injected into the LC-MS/MS system.

\section{Thermal stability experiment (see Figure 1B)}

$1 \mathrm{~g}$ of feed was accurately weighed into a $15 \mathrm{~mL}$ Falcon tube (in quadruplicate). Then, $150 \mu \mathrm{L}$ of a $20 \mathrm{ng} \cdot \mu \mathrm{L}^{-1}$ standard solution containing CLP-M and PM were added in each tube and kept aging for 30 min (spiking level, $\left.3 \mathrm{mg} \cdot \mathrm{kg}^{-1}\right)$. Then, $2 \mathrm{~mL}$ of ACN:acetone (80:20) with $1 \% \mathrm{HCOOH}$ were added to one tube (QC tube) which was vigorously shaken by Vortex for 1 $\min$. The other three tubes were subjected to the simulated conditions of the feed production process. To this aim, samples were heated in an oven at $50^{\circ} \mathrm{C}$ for one hour. After that, they were extracted identically to the QC tube. The samples were centrifuged at $6000 \mathrm{rcf}$ for $5 \mathrm{~min}$ and $100 \mu \mathrm{L}$ of the extract were diluted to $100 \mathrm{~mL}$ with water. Finally, $100 \mu \mathrm{L}$ of $25 \mathrm{ng} \cdot \mathrm{mL}^{-1} \mathrm{SIL}-\mathrm{IS}$ solution were added to $1 \mathrm{~mL}$ of the diluted extract, which was filtered through $0.45 \mu \mathrm{m}$ nylon filters, and $2 \mu \mathrm{L}$ were injected into the LC-MS/MS QqQ system. 

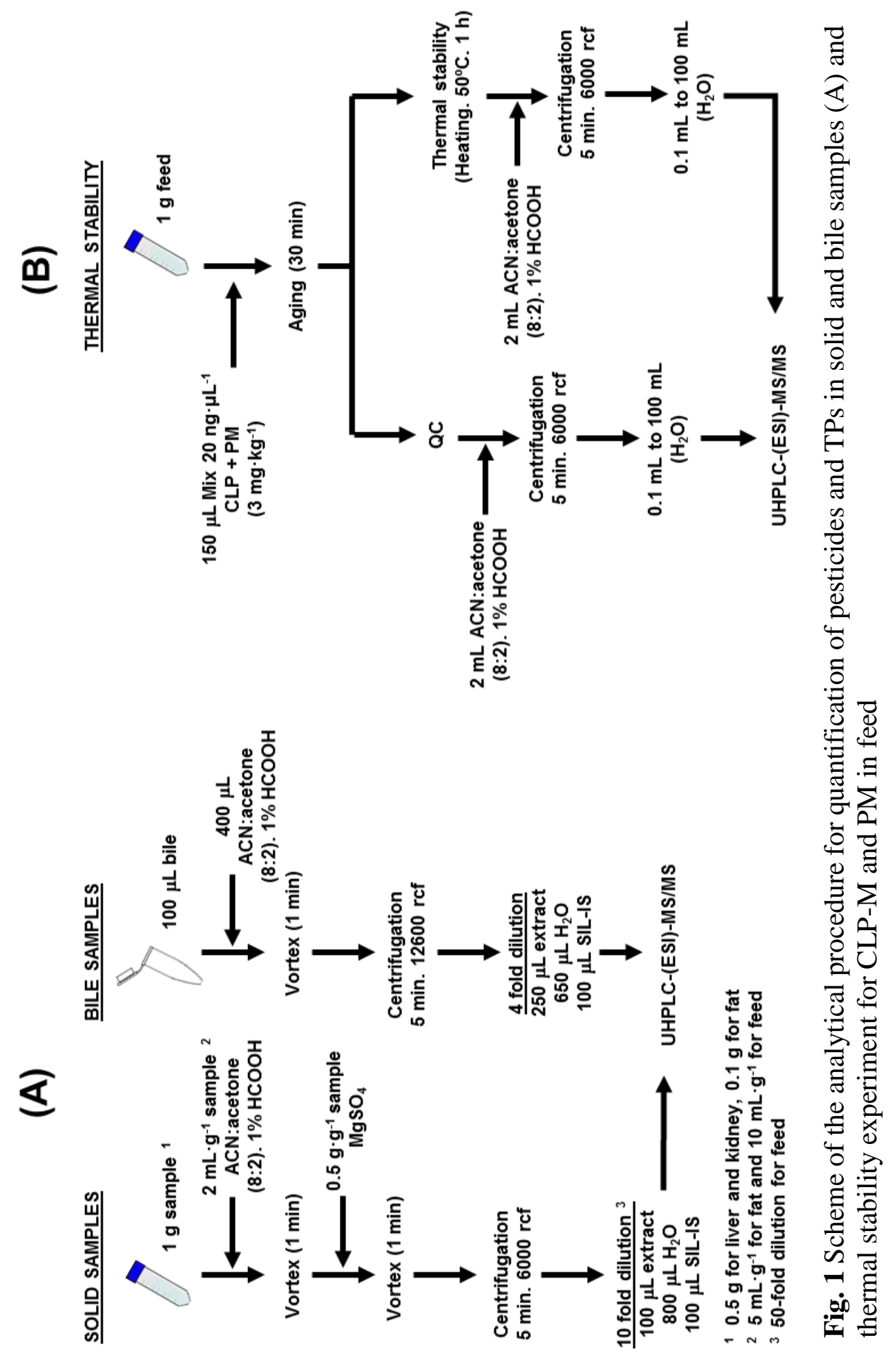

B. Garlito et al., Anal. Bioanal. Chem (2019) 


\subsection{Validation study}

Quantitative validation of the method was performed by evaluating the following parameters:

-Linearity: The calibration curves were obtained by injecting ten reference standards in solvent (except for bile, where matrix-matched calibration was applied) in the range $0.025-25 \mathrm{ng} \cdot \mathrm{mL}^{-1}$ at the beginning and the end of the validation batch. Linearity was assumed when the regression coefficient was higher than 0.99 with residuals lower than $20 \%$ and the difference between initial and final calibration curves did not exceed $30 \%$ (RSD $\leq 30 \%$ of the SIL-IS signal for those compounds whose quantification was carried out using relative areas).

-Trueness and precision: Trueness was evaluated by means of recovery experiments, analyzing zebrafish, muscle, liver and bile matrices in sextuplicates at three concentrations: 1,10 and $100 \mu \mathrm{g} \cdot \mathrm{kg}^{-1}\left(\mathrm{ng} \cdot \mathrm{mL}^{-1}\right.$ for bile). Blank matrices were not available for kidney and fat tissue hence validation was performed by the analysis of the lowest contaminated samples spiked at 10 and $100 \mu \mathrm{g} \cdot \mathrm{kg}^{-1}$, and 500 and $5000 \mu \mathrm{g} \cdot \mathrm{kg}^{-1}$, respectively. No replicates could be performed for fat tissue, due to the small amount of sample available. Feed matrix was validated at 500 and $5000 \mu \mathrm{g} \cdot \mathrm{kg}^{-1}$ due to the characteristics of the samples. Precision, expressed as the repeatability of the method, was evaluated in terms of relative standard deviation (RSD) from recovery experiments at each fortification level $(n=6)$. Quantification was performed by means of calibration curves in solvent using relative responses to the selected SIL-IS (see Table 1), except for bile which was quantified using matrixmatched calibration curves. Recoveries (between 70-120\%) and RSDs (below

B. Garlito et al., Anal. Bioanal. Chem (2019) 
20\%) were considered as satisfactory, according to SANTE/11813/2017 guideline (17).

-Limit of quantification (LOQ) was defined as the lowest concentration satisfactorily validated, following the SANTE/11813/2017 guideline criteria (recoveries 70-120 and RSDs < 20\%) (17).

-Limit of detection (LOD) was estimated, from the quantification transition, as the analyte concentration that produced a peak signal with a signal-to-noise ratio of 3 from the chromatogram at the lowest fortification level.

-Specificity was evaluated by verification of the absence of interfering peaks at the retention times of each compound in blank samples. To this aim, the response of a potential peak in the blank sample should be lower than $30 \%$ of the lowest level validated.

\section{Results and discussion}

\subsection{Screening of salmon liver, kidney and muscle using LC-(Q)TOF MS}

As stated in the "Reasoned opinion on the review of the existing maximum residue levels (MRLs) for pirimiphos-methyl according to Article 12 of Regulation (EC) No 396/2005" (16), PM is mainly metabolized into the metabolites shown in Table S1 in the case of lactating goat milk, muscle, liver, kidney and fat. However, to our knowledge, information regarding dietary pirimiphos-methyl metabolism in teleost fish is currently lacking. Therefore, LC-(Q)TOF MS screening was applied in order to investigate the potential PM metabolites present in our samples. The Extracted Ion Chromatograms 
(XICs) at LE (0.005 Da mass window) were obtained for the theoretical masses of the (de)protonated molecules of the expected metabolites. As shown in Figure 2, PM seemed to be metabolized mainly into 2-DAMP (R46382) and N-Des-PM (R36341) in muscle, liver and kidney. Both metabolites have been reported to be toxicologically significant by the EFSA in order to generate appropriate MRLs (16). The other hydroxypyrimidine metabolites reported in warm-blooded animals were not detected in the fish samples. The identity of the compounds was determined by comparing the LE and HE spectra with those of the standards in solvent. Mass errors for the protonated molecules were in all cases below $\pm 1.5 \mathrm{ppm}$, and the main fragment ions did not exceeded \pm 4 ppm mass errors.

Table S1. List of the main pirimiphos-methyl metabolites and their related structural formula.

\begin{tabular}{|c|c|c|c|}
\hline $\begin{array}{l}\text { Common } \\
\text { name }\end{array}$ & IUPAC name & Abbreviation & Structural formula \\
\hline R46382 & $\begin{array}{l}\text { 2-(diethylamino)-4-hydroxy-6- } \\
\text { methylpyrimidin }\end{array}$ & 2-DAMP & \\
\hline $\mathrm{R} 35510$ & $\begin{array}{c}\text { 2-(ethylamino)-6-methyl pyrimidin-4- } \\
\text { ol }\end{array}$ & 2-EAMP & \\
\hline R36341 & $\begin{array}{l}\text { O-[2-(ethylamino)-6-methylpyrimidin- } \\
\text { 4- yl] O,O-dimethyl phosphorothioate }\end{array}$ & N-Des-PM & \\
\hline R4039 & 2-amino-4-hydroxy-6-methylpyrimidin & 2-AMP & \\
\hline R4041 & 2-hydroxy-6-methylpyrimidin-4-ol & 2-OH-MP & \\
\hline
\end{tabular}




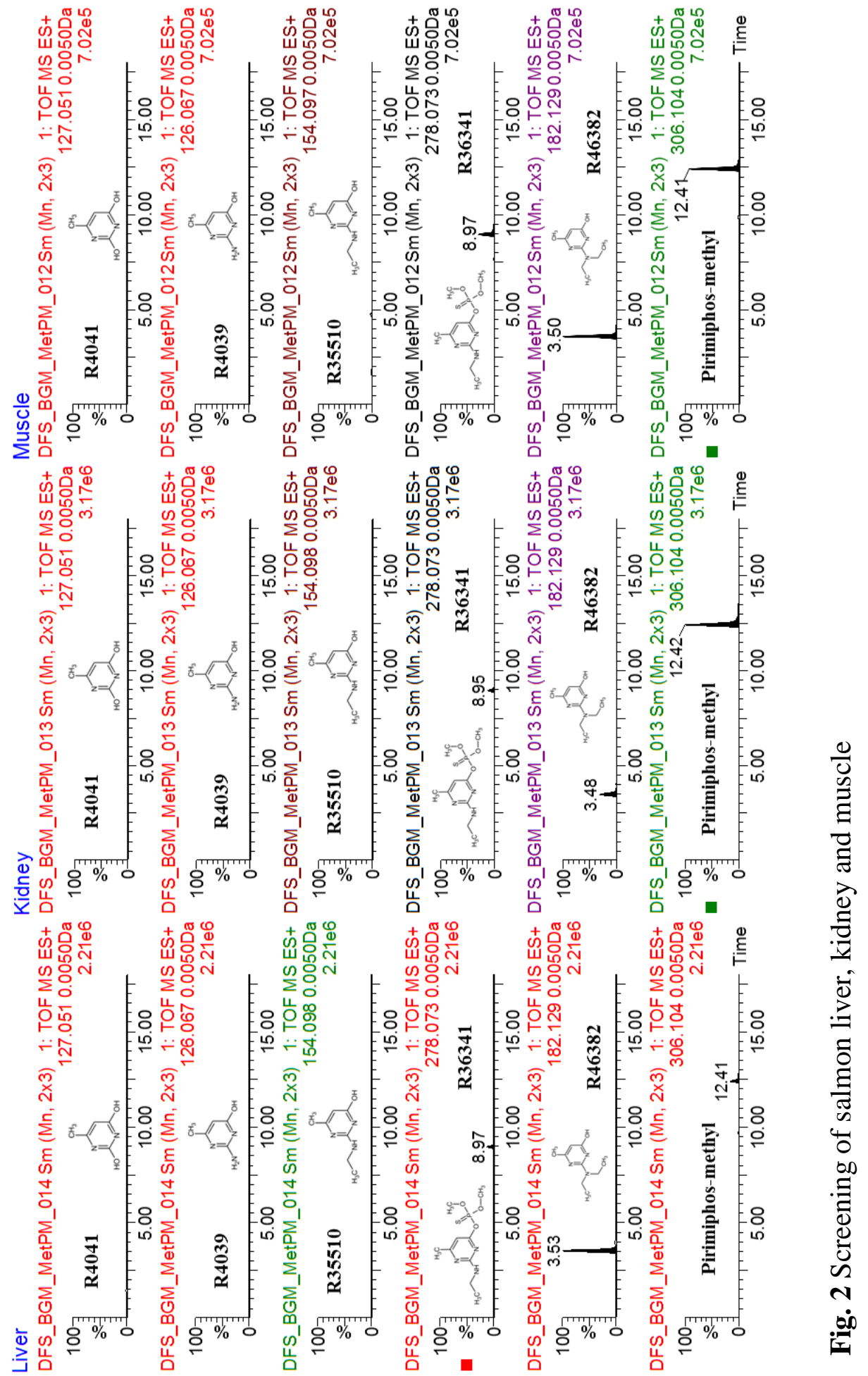


From the results obtained after screening of metabolites, a LC-MS/MS QqQ quantitative method was developed for the determination of PM, 2-DAMP and N-Des-PM in different fish tissues.

\subsection{Optimization of LC-MS/MS QqQ conditions}

The MS parameters were optimized by direct infusion of $0.1 \mathrm{ng} \cdot \mu \mathrm{L}^{-1}$ individual standard solutions in methanol:water $(1: 1) 0.01 \% \mathrm{FA}$ at a flow rate of $10 \mu \mathrm{L} \cdot \mathrm{min}^{-1}\left(25 \mu \mathrm{L} \cdot \mathrm{min}^{-1}\right.$ for CLP and TCP $)$. The optimal cone voltage and collision energies finally selected are shown in Table 1.

Regarding LC conditions, different mobile phases $\left(\mathrm{H}_{2} \mathrm{O}, \mathrm{MeOH}\right.$ and $\left.\mathrm{ACN}\right)$ and additives ( $\mathrm{HCOOH}$ and $\left.\mathrm{NH}_{4} \mathrm{OAc}\right)$ were tested. For most of the compounds except TCP, sensitivity improved using a mobile phase containing $0.01 \% \mathrm{HCOOH}$. Decreasing the $\mathrm{HCOOH}$ concentration to $0.0025 \%$, improved the peak shape for TCP and sensitivity was not substantially affected. Finally, $\mathrm{H}_{2} \mathrm{O}: \mathrm{ACN}$ with $0.0025 \% \mathrm{HCOOH}$ was used for the analysis of samples.

The $\mathrm{q}_{\mathrm{i}} / \mathrm{Q}$ ratio ( $\mathrm{q}_{\mathrm{i}}$ identification transition; $\mathrm{Q}$ quantification transition), of the chromatographic peaks in samples were compared with those of the reference standard (average value for standard solutions at $1,5,10$ and $25 \mathrm{ng} \cdot \mathrm{mL}^{-1}$; see Table 1) for identification of the compounds, with a tolerance in deviations $\pm 30 \%$. 
Table 1. Experimental conditions of the optimized UHPLC-ESI-MS/MS method. Quantification $(\mathrm{Q})$ and identification $\left(\mathrm{q}_{\mathrm{i}}\right)$ ions, collision energy $(\mathrm{CE})$, cone voltage $(\mathrm{CV}), \mathrm{q}_{\mathrm{i}} / \mathrm{Q}$ ratio and linear range.

\begin{tabular}{|c|c|c|c|c|c|c|c|c|c|}
\hline $\begin{array}{c}\mathrm{Rt} \\
(\min )\end{array}$ & Compound & $\begin{array}{l}\text { Internal } \\
\text { standard }\end{array}$ & & $\begin{array}{l}\text { Precursor } \\
\text { ion }\end{array}$ & $\begin{array}{l}\text { Product } \\
\text { ion }\end{array}$ & $\begin{array}{l}\mathrm{CE} \\
(\mathrm{eV})\end{array}$ & $\begin{array}{l}\text { CV } \\
\text { (V) }\end{array}$ & $\mathrm{q}_{\mathrm{i}} / \mathrm{Q}$ & $\begin{array}{l}\text { Linear } \\
\text { range } \\
\left(\mathrm{ng} \cdot \mathrm{mL}^{-1}\right)\end{array}$ \\
\hline \multirow[t]{5}{*}{0,53} & 2-DAMP & PM D6 & $\mathrm{Q}$ & 182.1 & 84.1 & 20 & 30 & & \multirow{5}{*}{$\begin{array}{c}0.025- \\
25\end{array}$} \\
\hline & & & $\mathrm{q}_{1}$ & & 109.1 & 25 & & 0.41 & \\
\hline & & & $\mathrm{q}_{2}$ & & 137.1 & 20 & & 0.38 & \\
\hline & & & $\mathrm{q}_{3}$ & & 126.1 & 20 & & 0.21 & \\
\hline & & & $\mathrm{q}_{4}$ & & 99.0 & 20 & & 0.14 & \\
\hline 1,13 & $\mathrm{TCP}{ }^{13} \mathrm{C}_{3}$ & & $\mathrm{Q}$ & 203 & 203 & 5 & 20 & & \\
\hline \multirow[t]{3}{*}{1,14} & \multirow[t]{3}{*}{$\mathrm{TCP}$} & \multirow{3}{*}{$\begin{array}{l}\mathrm{TCP} \\
{ }^{13} \mathrm{C}_{3}\end{array}$} & Q & 196 & 196 & 5 & 10 & & \multirow{3}{*}{$0.25-25$} \\
\hline & & & $\mathrm{q}_{1}$ & 198 & 197.9 & 5 & & 0.86 & \\
\hline & & & $\mathrm{q}_{2}$ & 200 & 199.8 & 5 & & 0.26 & \\
\hline \multirow[t]{5}{*}{1,24} & \multirow[t]{5}{*}{ N-Des-PM } & \multirow[t]{5}{*}{$\mathrm{PM} \mathrm{D}_{6}$} & $\mathrm{Q}$ & 278,1 & 125.1 & 25 & 40 & & \multirow{5}{*}{$\begin{array}{c}0.025- \\
25\end{array}$} \\
\hline & & & $\mathrm{q}_{1}$ & & 67.1 & 35 & & 1.2 & \\
\hline & & & $\mathrm{q}_{2}$ & & 108.1 & 25 & & 1.0 & \\
\hline & & & $\mathrm{q}_{3}$ & & 246 & 15 & & 0.62 & \\
\hline & & & $\mathrm{q}_{4}$ & & 100.1 & 20 & & 0.46 & \\
\hline 2,79 & CLP-M D6 & & Q & 330 & 131 & 20 & 20 & & \multirow{6}{*}{$0.25-25$} \\
\hline \multirow[t]{5}{*}{2,82} & \multirow[t]{5}{*}{ CLP-M } & \multirow[t]{5}{*}{$\begin{array}{c}\text { CLP-M } \\
\text { D6 }\end{array}$} & Q & 322 & 290 & 15 & 30 & & \\
\hline & & & $\mathrm{q}_{1}$ & & 125.1 & 20 & & 2.6 & \\
\hline & & & $\mathrm{q}_{2}$ & & 79.1 & 30 & & 0.62 & \\
\hline & & & $\mathrm{q}_{3}$ & & 109.1 & 20 & & 0.38 & \\
\hline & & & $\mathrm{q}_{4}$ & & 212 & 30 & & 0.21 & \\
\hline 2,86 & $\mathrm{PM} \mathrm{D}_{6}$ & & $\mathrm{Q}$ & 312,2 & 284.2 & 20 & 10 & & \\
\hline \multirow[t]{5}{*}{2,87} & PM & PM D6 & Q & 306,1 & 108.1 & 30 & 10 & & \multirow{5}{*}{$\begin{array}{c}0.025- \\
25\end{array}$} \\
\hline & & & $\mathrm{q}_{1}$ & & 67.1 & 40 & & 0.90 & \\
\hline & & & $\mathrm{q}_{2}$ & & 164.1 & 20 & & 0.84 & \\
\hline & & & $\mathrm{q}_{3}$ & & 95.1 & 25 & & 0.45 & \\
\hline & & & $\mathrm{q}_{4}$ & & 136.2 & 25 & & 0.26 & \\
\hline
\end{tabular}

\subsection{Sample treatment optimization and matrix effect study}

Sample treatment for solid matrices was optimized in order to get the maximum recovery with the simplest method possible. Different extraction 
systems, followed by several clean-up sorbents were tested. Recovery experiments were carried out at $50 \mu \mathrm{g} \cdot \mathrm{kg}^{-1}$ in triplicate using salmon fillet as the reference matrix (spiked samples were aged for $45 \mathrm{~min}$ ). Quantification was performed by matrix-matched calibration in each experiment.

The following solvents were firstly tested: ACN, ACN:acetone (80:20) and ACN:acetone (80:20) containing 1\% FA using mechanical agitator for 1 hour. It was found that CLP-M-oxon was rapidly converted to TCP after spiking the sample, causing the overestimation of TCP. This instability indicated that CLP-M-oxon should not be present in the samples, and therefore it was removed from the analytical method. Using ACN the less polar compounds (PM and CLP-M) showed low recoveries (68 and $56 \%$, respectively), which improved using ACN:acetone (80:20). The addition of 1\% FA to the later solvent mixture improved extraction efficiency (83-103\% recoveries) with a maximum RSD of $11 \%$ (see Figure 3.A). Thus, ACN:acetone (80:20) 1\% FA was chosen as the extractant solution in further studies.

Once the extractant was selected, different extraction times and techniques were evaluated. For this purpose, mechanical agitator (1 hour), vortex (1 min +1 min after adding $\mathrm{MgSO}_{4}$ ) and ultrasonic assisted extraction (US, $15 \mathrm{~min}$ ) were tested, selecting finally 2 min Vortex, as the most suitable and simplest system (see Figure 3.B). In order to ensure its extraction efficiency, an extra experiment consisting on the analysis of three spiked samples aged for 2 days at $7^{\circ} \mathrm{C}$ was performed, obtaining recoveries between 83 and $93 \%$, with $\mathrm{RSD}<5 \%$.

Several clean-up treatments were also evaluated: Z-Sep, Z-Sep ${ }^{+}$, freezing and 10-fold dilution. As can be seen in Figure 3.C, 10-fold dilution showed 
excellent recoveries (72-108\%), with RSD $<6 \%$, and was selected for the analysis of samples.

Prior to the analysis of samples, we performed an evaluation of matrix effects in the samples under study. To this aim, matrix-matched calibrations were prepared according to the sample treatment showed in Figure 1, in which 100 $\mu \mathrm{L}$ of the corresponding standard solution in $\mathrm{ACN}$ (between 1 and 250 $\mathrm{ng} \cdot \mathrm{mL}^{-1}$ ), instead of $100 \mu \mathrm{L}$ of the SIL-IS solution, were added to the final extract, resulting in final analyte concentrations between 0.1 and $25 \mathrm{ng} \cdot \mathrm{mL}^{-1}$. Matrix effect was evaluated by calculating the relative error between the slopes of the calibration graphs obtained with standards in solvent and in matrix (10).

Bile showed strong matrix effects for 2-DAMP and N-Des-PM (77 and 41\% signal suppression, respectively), whereas the rest of the compounds were not substantially affected (suppression of 7-21\%). Despite the notable ionization suppression observed, the required concentrations were still reached due to the high sensitivity of the method. In order to compensate matrix effects, the accurate quantification in bile samples was ensured by using matrix-matched calibration (with relative responses to SIL-IS only for PM, CLP and TCP). Regarding salmon fillet and liver, matrix effect ranged 4-28\% signal suppression for 2-DAMP, N-Des-PM, PM and TCP. CLP-M signal was 46 and 50\% suppressed in salmon and liver, respectively. Quantification using calibration in solvent with relative responses to the selected SIL-IS (see Table 1) provided satisfactory results in salmon fillet, liver, fat, kidney and feed. 


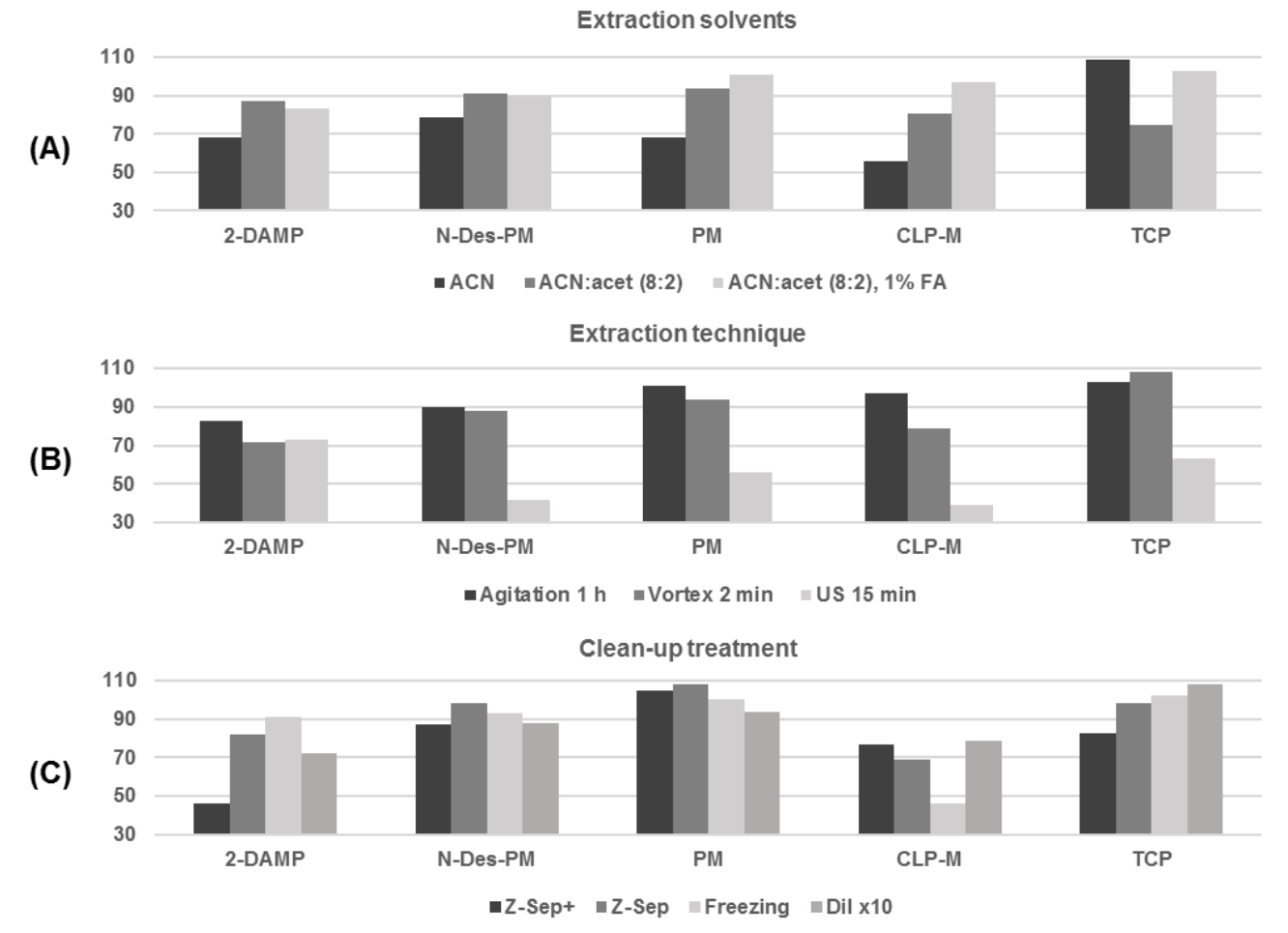

Fig. 3 Sample treatment optimization (A) extraction solvent, (B) extraction technique and $(\mathrm{C})$ clean-up treatment. Percentage recoveries are calculated as means of triplicate experiments at $50 \mu \mathrm{g} \cdot \mathrm{kg}^{-1}$

\subsection{Method validation}

Validation of the method was carried out with zebrafish, salmon tissues (fillet, liver, kidney, bile and fat), and salmon feed. The study of linearity in solvent revealed that correlation coefficients $\left(\mathrm{R}^{2}\right)$ were higher than 0.99 with residuals lower than 20\% for 2-DAMP, N-Des-PM and PM in the range 0.025-25 $\mathrm{ng} \cdot \mathrm{mL}^{-1}$ and $0.25-25 \mathrm{ng} \cdot \mathrm{mL}^{-1}$ for CLP-M and TCP. Matrix matched calibration for bile analysis also showed correlation coefficients $\left(\mathrm{R}^{2}\right)$ higher than 0.99 with residuals lower than $20 \%$ for PM and its TPs in the range 0.025 $25 \mathrm{ng} \cdot \mathrm{mL}^{-1}$, and $0.25-25 \mathrm{ng} \cdot \mathrm{mL}^{-1}$ for CLP-M and TCP.

B. Garlito et al., Anal. Bioanal. Chem (2019) 
Blank samples were pre-analyzed (except salmon kidney and salmon fat which were not available) in order to ensure the absence of interfering peaks at the retention time of the analytes of study. The method was found to be highly specific as no relevant signals were observed.

Trueness and precision data are shown in Table 2. For zebrafish, salmon muscle, liver and bile, recoveries ranged from 72 to $106 \%$, with RSD $\leq 16 \%$, for PM and its metabolites; and from 71 to $112 \%$, with RSD $\leq 12 \%$, for CLPM and TCP. CLP-M and TCP could only be validated at 10 and $100 \mu \mathrm{g} \cdot \mathrm{kg}^{-1}$ $\left(\mathrm{ng} \cdot \mathrm{mL}^{-1}\right)$ spiking levels. Although no EU regulations exist for marine products, the concentrations tested were lower than the precautional maximum residue limits (MRLs). Thus, LOQs were established at $1 \mu \mathrm{g} \cdot \mathrm{kg}^{-1}\left(\mathrm{ng} \cdot \mathrm{mL}^{-1}\right.$ in bile) for PM and its metabolites, and $10 \mu \mathrm{g} \cdot \mathrm{kg}^{-1}$ for CLP-M and TCP. For these matrices, LODs were in the range $0.1-0.6 \mu \mathrm{g} \cdot \mathrm{kg}^{-1}\left(\mathrm{ng} \cdot \mathrm{mL}^{-1}\right.$ in bile) and $2.5-8,0 \mu \mathrm{g} \cdot \mathrm{kg}^{-1}\left(\mathrm{ng} \cdot \mathrm{mL}^{-1}\right.$ in bile), respectively.

Blank samples were not available for kidney and fat tissue. Consequently, analyzed samples with the lowest contamination levels were subsequently spiked for validation experiments, at a level at least three times the concentration present. Recoveries were then calculated by subtracting "blank" concentration. In kidney, the spiking levels were 10 and $100 \mu \mathrm{g} \cdot \mathrm{kg}^{-1}$ as the concentrations of PM and 2-DAMP in the "blank" sample were 2.4 and 2.9 $\mu \mathrm{g} \cdot \mathrm{kg}^{-1}$, respectively. Trueness and precision were estimated in sextuplicates, obtaining recoveries between $70-82 \%$ (RSD < 9\%) for PM and its metabolites, and 72 - 87\% (RSD < 15\%) for CLP-M and TCP. LODs were calculated from the "blank" samples used. Fat could be validated by a single QC spiked at 500 and $5000 \mu \mathrm{g} \cdot \mathrm{kg}^{-1}$ due to the low amount of sample available. The spiking levels were selected based on the concentrations found in the 
"blank" samples $\left(666,56.5\right.$ and $102 \mu \mathrm{g} \cdot \mathrm{kg}^{-1}$ for PM, 2-DAMP and N-Des-PM, respectively). Recoveries ranged 71 to $105 \%$.

Salmon feed was validated at 500 and $5000 \mu \mathrm{g} \cdot \mathrm{kg}^{-1}$ as the experimental design of the study established $3000 \mu \mathrm{g} \cdot \mathrm{kg}^{-1}$ as the approximated concentration of PM and CLP for feeding trials. Recoveries ranged $74-84 \%$ with $\mathrm{RSD}<6 \%$ for parent compounds. N-Des-PM and TCP were not evaluated as they were not of interest in the analysis.

Table 2. Validation of the analytical method. Mean recoveries (\%) and RSD $(\%$, in brackets) of the overall procedure $(n=6)$. Estimated limits of detection (LOD).

\begin{tabular}{ccccc} 
& \multicolumn{4}{c}{ Zebrafish $\left(\mu \mathrm{g} \cdot \mathrm{kg}^{-1}\right)$} \\
\cline { 2 - 5 } & 1 & 10 & 100 & LOD \\
\hline PM & $73(6)$ & $89(7)$ & $91(4)$ & 0.1 \\
2-DAMP & $96(8)$ & $83(9)$ & $83(6)$ & 0.2 \\
N-Des-PM & $91(13)$ & $87(9)$ & $82(8)$ & 0.3 \\
CLP-M & $-{ }^{\mathrm{a}}$ & $80(6)$ & $81(6)$ & 2.5 \\
TCP & $-^{\mathrm{a}}$ & $71(2)$ & $105(10)$ & 3.3
\end{tabular}

\begin{tabular}{cccc}
\multicolumn{4}{c}{ Salmon muscle $\left(\mu \mathrm{g} \cdot \mathrm{kg}^{-1}\right)$} \\
\hline 1 & 10 & 100 & LOD \\
\hline $84(7)$ & $82(7)$ & $83(11)$ & 0.1 \\
$97(10)$ & $94(10)$ & $101(14)$ & 0.2 \\
$82(6)$ & $86(9)$ & $87(11)$ & 0.6 \\
$-^{\mathrm{a}}$ & $90(12)$ & $86(8)$ & 2.0 \\
- $^{\mathrm{a}}$ & $112(9)$ & $100(12)$ & 8.0
\end{tabular}

\begin{tabular}{ccccc} 
& \multicolumn{4}{c}{ Salmon liver $\left(\mu \mathrm{g} \cdot \mathrm{kg}^{-1}\right)$} \\
\cline { 2 - 5 } & 1 & 10 & 100 & LOD \\
\hline PM & $77(1)$ & $80(4)$ & $82(9)$ & 0.1 \\
2-DAMP & $91(10)$ & $83(4)$ & $72(10)$ & 0.3 \\
N-Des-PM & $107(10)$ & $95(2)$ & $92(6)$ & 0.4 \\
CLP-M & $-^{\mathrm{a}}$ & $111(4)$ & $104(8)$ & 2.0 \\
TCP & $-^{\mathrm{a}}$ & $96(3)$ & $105(7)$ & 7.6
\end{tabular}

\begin{tabular}{cccc}
\multicolumn{4}{c}{ Salmon bile $\left(\mathrm{ng} \cdot \mathrm{mL}^{-1}\right)$} \\
\hline 1 & 10 & 100 & LOD \\
\hline $90(6)$ & $94(9)$ & $106(5)$ & 0.1 \\
$89(16)$ & $89(10)$ & $101(15)$ & 0.3 \\
$75(5)$ & $72(11)$ & $77(5)$ & 0.3 \\
-a $^{-a}$ & $100(9)$ & $107(4)$ & 1.8 \\
$-{ }^{-}$ & $92(11)$ & $107(4)$ & 4.5
\end{tabular}

\begin{tabular}{|c|c|c|c|c|c|c|c|c|c|}
\hline & \multicolumn{3}{|c|}{ Salmon kidney $\left(\mu \mathrm{g} \cdot \mathrm{kg}^{-1}\right)$} & \multicolumn{3}{|c|}{ Salmon fat $\left(\mu \mathrm{g} \cdot \mathrm{kg}^{-1}\right)$} & \multicolumn{3}{|c|}{ Feed $\left(\mu \mathrm{g} \cdot \mathrm{kg}^{-1}\right)$} \\
\hline & 10 & 100 & LOD & 500 & 5000 & LOD & 500 & 5000 & LOD \\
\hline PM & $80(9)$ & $82(6)$ & 0.1 & $-\mathrm{b}$ & 87 & d & $74(2)$ & $75(2)$ & d \\
\hline 2-DAMP & $73(3)$ & $70(5)$ & 0.3 & 96 & 105 & d & $85(3)$ & $92(4)$ & d \\
\hline N-Des-PM & $80(8)$ & $78(5)$ & 0.4 & 94 & 89 & d & $-^{c}$ & -c $^{\mathrm{c}}$ & d \\
\hline CLP-M & $72(15)$ & $74(7)$ & 2.0 & 81 & 78 & d & $81(2)$ & $84(6)$ & d \\
\hline TCP & $80(6)$ & $87(15)$ & 7.3 & 71 & 95 & d & $-^{\mathrm{c}}$ & $-^{\mathrm{c}}$ & d \\
\hline
\end{tabular}

${ }^{\mathrm{a}}$ Limit of detection $>$ lowest spiking level $\left(1 \mu \mathrm{g} \cdot \mathrm{kg}^{-1}\left(\mathrm{ng} \cdot \mathrm{mL}^{-1}\right)\right)$.

${ }^{\mathrm{b}}$ Blank concentration $>$ spiking level.

${ }^{\mathrm{c}}$ Compounds out of interest from the purpose of the analysis.

${ }^{d}$ Very high concentrations to calculate LODs 


\subsection{Thermal stability study of parent compounds}

In order to assess the thermal stability of CLP and PM in feed, a trial simulating the conditions employed in feed production process $\left(1 \mathrm{~h}, 50^{\circ} \mathrm{C}\right)$ was carried out. The experiment was performed in triplicate, and results were compared with a QC that was not subjected to elevated temperature. The percentage of pesticide degradation was calculated by using Equation 1:

$$
\% \text { degradation }=100-\frac{\% \text { recovery Trial }}{\% \text { recovery } \mathrm{QC}} \times 100
$$

As shown in Table S2, CLP and PM did not show relevant degradation at the production temperature conditions, with partial degradation of 15 and $17 \%$, respectively. It was found that $\mathrm{PM}$ was degraded to 2-DAMP, generating a considerable background in the final diets (see Table $\mathbf{3}$ ).

Table S2. Thermal stability results. Numbers in bold are the mean values of $\%$ degradation for PM and CLP with their RSD (in brackets).

\begin{tabular}{|c|c|c|c|c|c|c|}
\hline \multicolumn{4}{|c|}{ Pirimiphos-methyl } & \multicolumn{3}{|c|}{$\underline{\text { Chlorpyrifos-methyl }}$} \\
\hline & $\mathrm{mg} \cdot \mathrm{kg}^{-1}$ & $\begin{array}{c}\text { Recovery } \\
(\%)\end{array}$ & $\begin{array}{c}\text { Degradation } \\
(\%)\end{array}$ & $\mathrm{mg} \cdot \mathrm{kg}^{-1}$ & $\begin{array}{c}\text { Recovery } \\
(\%)\end{array}$ & $\begin{array}{c}\text { Degradation } \\
(\%)\end{array}$ \\
\hline QC & 2.27 & 75.6 & & 2.47 & 82.3 & \\
\hline Feed 1 & 1.85 & 61.6 & 18 & 2.07 & 69.2 & 16 \\
\hline Feed 2 & 1.90 & 63.3 & 16 & 2.09 & 69.6 & 15 \\
\hline Feed 3 & 1.88 & 62.8 & 17 & 2.13 & 71.1 & 14 \\
\hline & & & $17(6)$ & & & $15(8)$ \\
\hline
\end{tabular}

\subsection{Quantitative analysis of samples in dietary exposed fish}

The developed method was applied for the analysis of zebrafish samples, salmon fillet, salmon liver, salmon kidney, salmon bile and diets. A reagent 
blank, a reagent blank spiked with SIL-IS (to evaluate SIL-IS stability), a blank (non-spiked) sample and 9 spiked samples ( 3 at each validation level) were included in each batch. Each matrix was analyzed in different batches. The results summarized in Table 3 corresponding to the analysis of solid fish tissues are expressed in a wet weight basis, whereas those which correspond to bile analysis, are expressed in $\mathrm{ng} \cdot \mathrm{mL}^{-1}$. The $\mathrm{q}_{\mathrm{i}} / \mathrm{Q}$ ratios obtained for all positive samples were in agreement with those of the reference standards with deviations lower than the maximum tolerance accepted (30\%). This data confirmed the identity of the compounds in samples according to the SANTE/11813/2017 guideline (17).

In whole zebrafish fed with CLP-M, TCP was the main metabolite and was present in higher concentrations (approximately two fold higher) than the parent compound. For PM, both 2-DAMP and N-Des-PM metabolites were identified in whole zebrafish, but at lower levels than the parent compound (see Figure 4). As for zebrafish, also for Atlantic salmon the main PM metabolites were 2-DAMP and N-Des-PM. The distribution of the PM metabolites showed highest concentrations for 2-DAMP, higher than the parent compound, in the liver which is likely the main organ of metabolisation. This is confirmed by the higher concentrations of 2-DAMP in the bile. The second metabolite, N-Des-PM, was found in all tissues (muscle, liver, kidney) at concentrations in the same range $\left(3-6 \mu \mathrm{g} \cdot \mathrm{kg}^{-1}\right)$. The parent compound, PM, had highest levels in the fat tissue. Similarly, EFSA concludes that PM in commodities of animal origin is fat soluble and, in goat, parent pirimiphosmethyl was the main compound, accounting for $55 \%$ of the total radioactive residue (16). 
Trial 2

AQUASAFE 1143

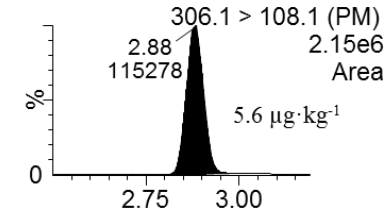

AQUASAFE 1143

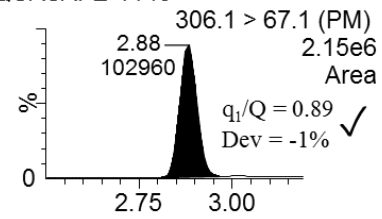

AQUASAFE 1143

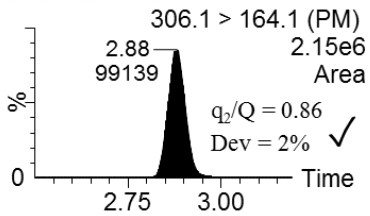

(A)
Trial 2

AQUASAFE 1143

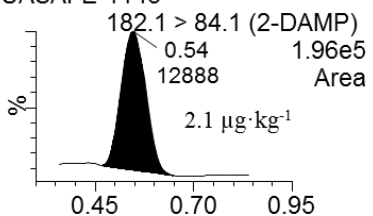

AQUASAFE 1143

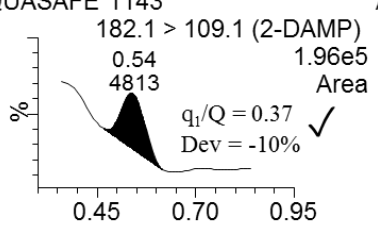

AQUASAFE 1143

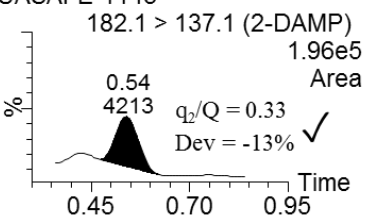

(B)
Trial 2

AQUASAFE 1143

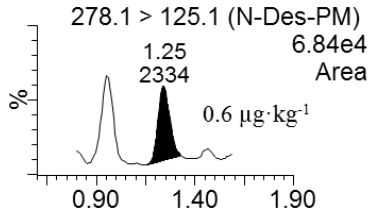

AQUASAFE 1143

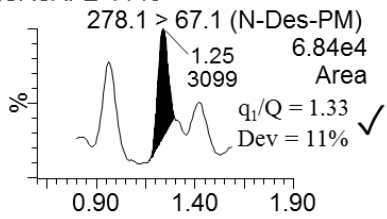

AQUASAFE 1143

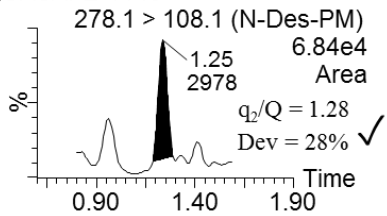

(C)
Trial 1

AQUASAFE 1142

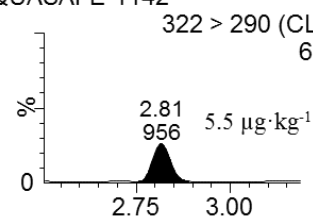

AQUASAFE 1142

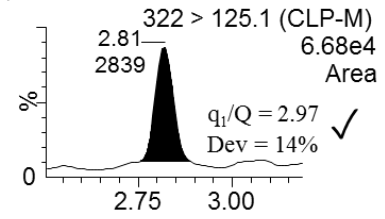

AQUASAFE 1142

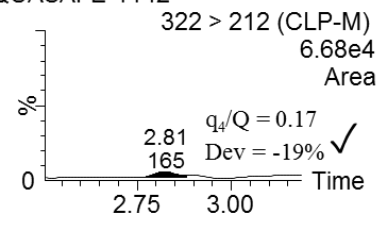

(D)
Trial 1

AQUASAFE 1142

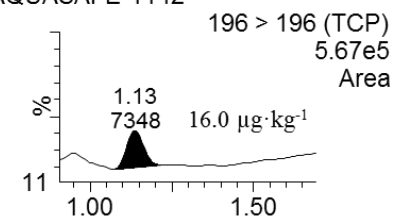

AQUASAFE 1142

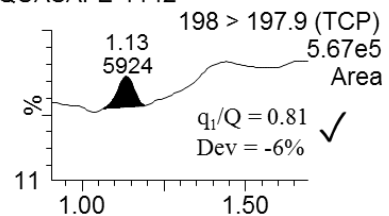

AQUASAFE 1142

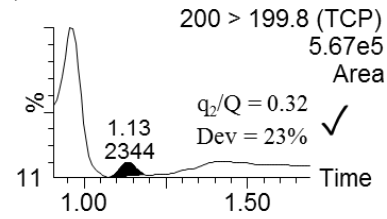

(E)

Fig. 4 UHPLC-(ESI)-MS/MS chromatograms obtained for the quantification and identification of A) PM $\left(5.6 \mu \mathrm{g} \cdot \mathrm{kg}^{-1}\right)$, B) 2-DAMP $\left.\left(2.1 \mu \mathrm{g} \cdot \mathrm{kg}^{-1}\right), \mathrm{C}\right) \mathrm{N}$ Des-PM (0.6 $\left.\mu \mathrm{g} \cdot \mathrm{kg}^{-1}\right)$, D) CLP-M $\left(5.5 \mu \mathrm{g} \cdot \mathrm{kg}^{-1}\right)$ and E) TCP $\left(16.0 \mu \mathrm{g} \cdot \mathrm{kg}^{-1}\right)$; in zebrafish samples. Q: quantification transition; $\mathrm{q}_{\mathrm{i}}$ : identification transitions. $\checkmark$ $\mathrm{q} / \mathrm{Q}$ within accepted tolerances 
Table 3. Concentration of PM, 2-DAMP, N-Des-PM, CLP-M and TCP in zebrafish, salmon muscle, liver, kidney, fat and bile.

\begin{tabular}{ccccccc} 
& $\left(\mu \mathrm{g} \cdot \mathrm{kg}^{-1}\right)$ & PM & 2-DAMP & N-Des-PM & CLP-M & TCP \\
\hline \multirow{4}{*}{ Zebrafish } & Trial 1 & n.d & 0.7 & n.d & 5.5 & 16.0 \\
& Trial 2 & 5.6 & 2.1 & 0.6 & n.d \\
Trial 4 & n.d & 0.6 & n.d & n.d & n.d \\
\hline \multirow{2}{*}{ Feed } & Trial 1 & n.d & 200 & n.d & 1600 & n.d \\
& Trial 2 & 2300 & 500 & n.d & n.d & n.d \\
& Trial 4 & n.d & 200 & n.d & n.d & n.d \\
muscle & T81 & 28.2 & 18.0 & 3.4 & n.d & n.d \\
liver & T81 & 6.1 & 28.8 & 5.9 & n.d & n.d \\
Fidney & T81 & 22.4 & 16.8 & 3.1 & n.d & n.d \\
& T81 & 2757 & 75.5 & 346 & n.d & n.d \\
\hline \multirow{2}{*}{ Bile } & T81 & 48.0 & 205 & 89.1 & n.d & n.d \\
\hline
\end{tabular}

n.d: not detected. Concentration < LOD

\section{Conclusions}

A fast, simple and sensitive method for the determination of PM, CLP-M and their main metabolites in different fish tissues has been developed. Previous LC-(Q)TOF screening demonstrated that cold-blooded fish show a different metabolism of PM than in warm-blooded animals, with 2-DAMP and N-DesPM being the most abundant metabolites in salmon. This was supported by analysis performed in the present work. The application of this method to zebrafish fed with CLP-M also allowed the identification of TCP as the most abundant metabolite. This work has generated analytical information essential for developing a kinetic model of accumulation and elimination of PM in salmon, and will contribute to establish relevant MRLs for fish. 


\section{Acknowledgements}

The present work was financed by the Norwegian Research Council (NFR) project "AQUASAFE" (254807). The authors wish to thank the staff at the Skretting ARC, Lerang Research Station for their excellent help with sampling and conducting the feeding trial. Tania Portolés acknowledges Ramon y Cajal Program from Ministry of Economy and Competitiveness (RYC-2017-22525) for funding her research.

\section{Compliance with ethical standards}

Conflict of interest: The authors state that there is no conflict of financial and non-financial interest.

Research involving animals: The experiment complied with the guidelines of the Norwegian Regulation on Animal Experimentation and EC Directive 86/609/EEC. The National Animal Research Authority approved the protocol (ID 12091).

\section{References}

1. Shepherd CJ, Jackson AJ. Global fishmeal and fish-oil supply: Inputs, outputs and marketsa. J Fish Biol. 2013;83(4):1046-66.

2. Ytrestøyl T, Aas TS, Åsgård T. Resource utilisation of Norwegian salmon farming in 2012 and 2013. Nofima Report 36/2014. 2014. Available from: https://nofima.no (accessed on $10^{\text {th }}$ September 2019). 
3. Berntssen MHG, Lundebye A-K, Torstensen BE. Reducing the levels of dioxins and dioxin-like PCBs in farmed Atlantic salmon by substitution of fish oil with vegetable oil in the feed. Aquac Nutr. 2005;11(3):219-31.

4. Berntssen MHG, Julshamn K, Lundebye A-K. Chemical contaminants in aquafeeds and Atlantic salmon (Salmo salar) following the use of traditionalversus alternative feed ingredients. Chemosphere. 2010;78(6):637-46.

5. Nácher-Mestre J, Serrano R, Portolés T, Berntssen MHG, Pérez-Sánchez J, Hernández F. Screening of pesticides and polycyclic aromatic hydrocarbons in feeds and fish tissues by gas chromatography coupled to high-resolution mass spectrometry using atmospheric pressure chemical ionization. J Agric Food Chem. 2014;62(10):2165-74.

6. Kaczyński P, Łozowicka B, Perkowski M, Szabuńko J. Multiclass pesticide residue analysis in fish muscle and liver on one-step extraction-cleanup strategy coupled with liquid chromatography tandem mass spectrometry. Ecotoxicol Environ Saf. 2017;138:179-89.

7. Belenguer V, Martinez-Capel F, Masiá A, Picó Y. Patterns of presence and concentration of pesticides in fish and waters of the júcar river (eastern spain). J Hazard Mater. 2014;265:271-9.

8. Zhang H, Wang J, Li L, Wang Y. Determination of 103 Pesticides and Their Main Metabolites in Animal Origin Food by QuEChERS and Liquid Chromatography-Tandem Mass Spectrometry. Food Anal Methods. 2017;10(6):1826-43.

9. Gan J, Lv L, Peng J, Li J, Xiong Z, Chen D, et al. Multi-residue method for the determination of organofluorine pesticides in fish tissue by liquid

B. Garlito et al., Anal. Bioanal. Chem (2019) 
chromatography triple quadrupole tandem mass spectrometry. Food Chem. 2016;207:195-204.

10. Botero-Coy AM, Marín JM, Serrano R, Sancho JV, Hernández F. Exploring matrix effects in liquid chromatography-tandem mass spectrometry determination of pesticide residues in tropical fruits. Anal Bioanal Chem. 2015 May;407(13):3667-81.

11. Portolés T, Ibáñez M, Garlito B, Nácher-Mestre J, Karalazos V, Silva J, et al. Comprehensive strategy for pesticide residue analysis through the production cycle of gilthead sea bream and Atlantic salmon. Chemosphere. 2017;179:242-53.

12. VKM. Benefit-risk assessment of fish and fish products in the Norwegian diet - an update. Scientific Opinion of the Scientific Steering Committee. VKM Report 15 [293 pp] 2014. Available online: www.vkm.no (accessed on $10^{\text {th }}$ September 2019)

13. Rao JV, Rani CHS, Kavitha P, Rao RN, Madhavendra SS. Toxicity of chlorpyrifos to the fish Oreochromis mossambicus. Bull Environ Contam Toxicol. 2003;70(5):985-92.

14. European Food Safety Authority. Modification of the existing MRLs for chlorpyrifos-methyl in various crops. EFSA J 2011;9(6):2219. doi:10.2903/j.efsa.2011.2219. Available online: www.efsa.europa.eu/ efsajournal (accessed on $10^{\text {th }}$ September 2019)

15. European Commission. Refined risk assessment regarding certain maximum residue levels (MRLs) of concern for the active substance chlorpyrifos. European Food Safety Authority (EFSA) 2015, Available 
online: https://www.efsa.europa.eu/en/efsajournal/pub/4142 (accessed on $10^{\text {th }}$ September 2019)

16. EFSA (European Food Safety Authority). Reasoned opinion on the review of the existing maximum residue levels (MRLs) for pirimiphos-methyl according to Article 12 of Regulation (EC) No 396/2005. EFSA J 2015;13(1):3974. Available from: http://doi.wiley.com/10.2903/j.efsa.2015. 3983 (accessed on $10^{\text {th }}$ September 2019)

17. SANTE/11813/2017. Guidance document on analytical quality control and validation procedures for pesticide residues analysis in food and feed. Available online: https://ec.europa.eu/food/sites/food/files/plant/docs/ pesticides_mrl_guidelines_wrkdoc_2017-11813.pdf. (accessed on $10^{\text {th }}$ September 2019) 


\subsection{Discusión de los resultados obtenidos}

El artículo científico III surge a partir de los resultados obtenidos en los artículos científicos I y II, con la intención de estudiar en profundidad el metabolismo y la cinética de bioacumulación y eliminación del pirimiphosmethyl en salmón atlántico y, así, contribuir a la armonización de la legislación del principio activo en toda la cadena de producción acuícola. Para ello, se desarrolló un método basado en el acoplamiento LC-MS/MS con analizador QqQ para el análisis de pez cebra y diferentes tejidos de salmón sometidos a varios experimentos de exposición dietaria.

En primer lugar, tras optimizar las condiciones espectrométricas y cromatográficas, se llevó a cabo la optimización del tratamiento de muestra en filete de salmón para el pirimiphos-methyl, el chlorpyrifos-methyl y los principales metabolitos reportados por la EFSA que estaban disponibles comercialmente [6,7]. Como se muestra en la figura 3 del artículo, el mejor compromiso entre sencillez, tiempo y recuperaciones se obtuvo en la extracción con ACN:acetona 80:20 al 1\% de $\mathrm{HCOOH}$ durante dos minutos en vórtex y una dilución final de diez veces. Llama la atención las bajas recuperaciones obtenidas mediante sonicación, quizás provocadas por la degradación de los analitos en el proceso de cavitación [8-10].

Una vez optimizado el tratamiento de muestra, se extrajeron y se realizó un screening mediante LC-QTOF MS de las muestras más expuestas a los contaminantes según el diseño experimental, a fin de estudiar los posibles metabolitos del pirimiphos-methyl presente en filete, hígado y riñones de salmón dada la ausencia de antecedentes científicos. Como se muestra en la figura 2 del artículo, los principales metabolitos detectados fueron el 2-DAMP 
y el N-Des-PM. Cabe mencionar que, pese a ser poco habitual la optimización del tratamiento de muestra en métodos de screening, la decisión de hacerlo estuvo motivada por la poca cantidad de riñón e hígado disponible, de modo que el mismo extracto crudo se pudo aprovechar para fines cualitativos y cuantitativos.

A partir de los resultados obtenidos, se validó el método cuantitativo para la determinación de pirimiphos-methyl, 2-DAMP, N-Des-PM, chlorpyrifosmethyl y TCP en pienso, pez cebra y filete, hígado, riñon, bilis y grasa de salmón; cumpliendo con los parámetros de validación establecidos por la guía SANTE/11813/2017 [11]. En el proceso de validación, el estudio previo del efecto matriz fue determinante para la selección de la estrategia de cuantificación dada la complejidad de las matrices. Por una parte, la bilis presentó una fuerte supresión de la señal para el 2-DAMP y el N-Des-PM que no se pudo corregir con los SIL-IS disponibles, lo que obligó a compensarla mediante calibrado en matriz. Por el contrario, el resto de matrices, pese a presentar supresión de señal para algunos compuestos, se pudieron cuantificar correctamente a los niveles deseados usando calibrado en solvente con respuestas relativas a los SIL-IS.

Por último, se analizaron las muestras de los experimentos de exposición dietaria en dos tandas. En la primera de ellas se determinaron todos los analitos mencionados en el párrafo anterior en muestras de pienso y pez cebra. En la segunda de ellas, únicamente se determinaron el pirimiphos-methyl y sus metabolitos en filete, hígado, riñón, bilis y grasa de salmón. La razón principal se debe al diseño de los experimentos de exposición dietaria en base a criterios toxicológicos. Por una parte, al experimento con pez cebra se aplicó un enfoque multicontaminante, es decir, una aproximación más cercana a la 
exposición ambiental que contempla las posibles interacciones sinérgicas o antagónicas de la mezcla de pirimiphos-methyl, chlorpyrifos-methyl y los adyuvantes que contienen los formulados comerciales. Por otra parte, y siguiendo las directrices de guías como la SANCO/11187/2013 o la reglamentación 440/2008(EC) para estudios de metabolismo y toxicocinéticos [12,13], el experimento con salmón se llevó a cabo desde un enfoque unicontaminante, es decir, expuesto únicamente a pirimiphos-methyl.

Si bien es cierto que, desde el punto de vista analítico, el artículo científico III puede resultar poco novedoso; no es menos cierto que, en un presente en el que no se pueden entender las ciencias ambientales fuera de un contexto multidisciplinar, este trabajo ha generado información analítica - la mayor parte de ella sin publicar - esencial para desarrollar, en un futuro inmediato, un modelo cinético de acumulación y eliminación de pirimiphos-methyl en el salmón que contribuirá a establecer MRLs seguros y objetivos en peces de acuicultura. 



\subsection{Referencias}

[1] J. Nácher-Mestre, R. Serrano, T. Portolés, M.H.G. Berntssen, J. PérezSánchez, F. Hernández, Screening of pesticides and polycyclic aromatic hydrocarbons in feeds and fish tissues by gas chromatography coupled to highresolution mass spectrometry using atmospheric pressure chemical ionization., J. Agric. Food Chem. 62 (2014) 2165-74. doi:10.1021/jf405366n.

[2] M.H.G. Berntssen, K. Julshamn, A.-K. Lundebye, Chemical contaminants in aquafeeds and Atlantic salmon (Salmo salar) following the use of traditional- versus alternative feed ingredients, Chemosphere. 78 (2010) 637-646. doi:10.1016/j.chemosphere.2009.12.021.

[3] European Commission, Draft Renewal Assessment Report prepared according to the Commission Regulation (EU) N $N^{\circ} 1107 / 2009$ - Pirimiphosmethyl. List of endpoints, 2009.

[4] VKM. Benefit-risk assessment of fish and fish products in the Norwegian diet - an update. Scientific Opinion of the Scientific Steering Committee. VKM Report 15 [293 pp] 2014. Available online: www.vkm.no (accessed on 10th September 2019).

[5] EFSA (European Food Safety Authority), Scientific Opinion on Evaluation of the Toxicological Relevance of Pesticide Metabolites for Dietary Risk Assessment, EFSA J. 10 (2012) 1-187. doi:10.2903/j.efsa. 2012.2799.

[6] EFSA (European Food Safety Authority), Conclusion on the peer review of the pesticide human health risk assessment of the active substance chlorpyrifos, EFSA J. 12 (2016) 1-34. doi:10.2903/j.efsa.2014.3640.

[7] EFSA (European Food Safety Authority). Reasoned opinion on the 
review of the existing maximum residue levels (MRLs) for pirimiphos-methyl according to Article 12 of Regulation (EC) No 396/2005. EFSA J 2015;13(1):3974. Available from: http://doi.wiley.com/10.2903/j.efsa.2015. 3983 (accessed on 10th September 2019).

[8] V. Andruch, M. Burdel, L. Kocúrová, J. Šandrejová, I.S. Balogh, Application of ultrasonic irradiation and vortex agitation in solvent microextraction, TrAC - Trends Anal. Chem. 49 (2013) 1-19. doi:10.1016/ j.trac.2013.02.006.

[9] B. Miljevic, F. Hedayat, S. Stevanovic, K.E. Fairfull-Smith, S.E. Bottle, Z.D. Ristovski, To sonicate or not to sonicate PM filters: Reactive oxygen species generation upon ultrasonic irradiation, Aerosol Sci. Technol. 48 (2014) 1276-1284. doi:10.1080/02786826.2014.981330.

[10] Y.G. Adewuyi, Sonochemistry: Environmental Science and Engineering Applications, Ind. Eng. Chem. Res. 40 (2001) 4681-4715.

[11] SANTE/11813/2017. Guidance document on analytical quality control and validation procedures for pesticide residues analysis in food and feed. Available online: https://ec.europa.eu/food/sites/food/files/plant/docs/ pesticides_mrl_guidelines_wrkdoc_2017-11813.pdf. (accessed on 10th September 2019).

[12] Comisión Europea, REGLAMENTO (CE) 440/2008, D. Of. La Unión Eur. 142 (2008) 1-739.

[13] European Commission, SANCO/11187/2013. Working document on the nature of pesticide residues in fish, (2013) 1-35. 


\section{CAPÍtULO 4}

DETERMINACIÓN DE COMPUESTOS ENDÓGENOS MEDIANTE EL USO DE ESPECTROMETRÍA DE MASAS CON ANALIZADOR DE CUADRUPOLOTIEMPO DE VUELO Y FUENTE DE IONIZACIÓN APCI 

CAPÍTULO 4: DETERMINACIÓN DE COMPUESTOS ENDÓGENOS MEDIANTE EL USO DE ESPECTROMETRÍA DE MASAS CON ANALIZADOR DE CUADRUPOLO-TIEMPO DE VUELO Y FUENTE DE IONIZACIÓN APCI

\subsection{Introducción}

\subsection{Artículo científico IV}

"Identification of very long-chain (>C24) fatty acid methyl esters using gas chromatography coupled to quadrupole/time-of-flight mass spectrometry with atmospheric pressure chemical ionization source"

Analytica Chimica Acta, 1051, 103-109, 2019

4.3. Discusión de los resultados obtenidos

4.4. Referencias 



\subsection{Introducción}

Actualmente, el pescado representa la principal fuente de ácidos grasos poliinsaturados de cadena larga de la serie $\omega 3$ (LC-PUFA 03 ) para el consumo humano, cuya importancia ha sido puesta de manifiesto en numerosos estudios que resaltan el papel fundamental de estos ácidos grasos en diversos procesos fisiológicos y metabólicos [1]. Esta circunstancia ha motivado, en gran medida, el estudio del metabolismo de LC-PUFA en peces y sus mecanismos de regulación con fines aplicados a la acuicultura. De hecho, estos compuestos son protagonistas ineludiblemente asociados al cultivo de peces puesto que esta actividad depende, durante las fases tempranas de cultivo, del adecuado aporte dietario de LC-PUFA $\omega 3$ dada la capacidad limitada de biosíntesis que tienen las especies marinas para satisfacer sus requerimientos fisiológicos [2].

A pesar de la enorme atención recibida por los LC-PUFA, como los ácidos

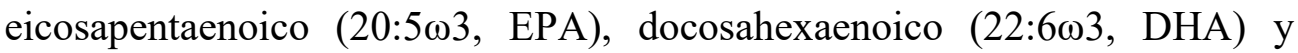

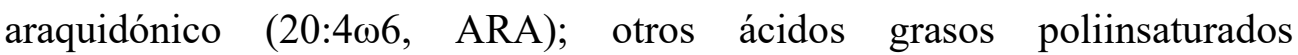
denominados de cadena muy larga $(\mathrm{C}>24)$ (very long-chain polyunsaturated fatty acids, VLC-PUFA) han sido prácticamente inexplorados en peces, lo cual es particularmente sorprendente si se tiene en cuenta que, como postularon Agbaga et al. [3], la síntesis de VLC-PUFA en mamíferos se produce por elongaciones sucesivas de LC-PUFA como el ácido

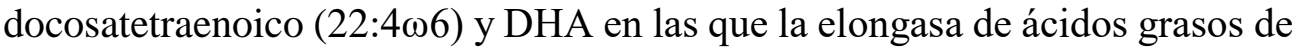
cadena muy larga 4 (ELOVL4) tiene un papel determinante. Además, varios estudios llevados a cabo en mamíferos, han demostrado la presencia de VLCPUFA en células fotorreceptoras de la retina [4-6], cerebro [7, 8] y testículos $[9,10]$, y se cree que estos compuestos están asociados a procesos vitales clave. De hecho, se ha demostrado que mutaciones genéticas en el gen 
ELOVL4 reduce el contenido de VLC-PUFA en la retina, provocando una pérdida de capacidad visual [6]. Pese a que la función de los VLC-PUFA en estos tejidos aún no se ha determinado, parece tener que ver con el hecho de que comparten propiedades de los ácidos grasos saturados en el extremo carboxílico proximal y de los poliinsaturados en la región distal de la molécula [11].

Relativo al ámbito de la acuicultura, estudios llevados a cabo en el pez cebra (Danio rerio) [12], en la cobia (Rachycentron canadum) [13], en el salmón atlántico (Salmo salar) [14] y en el pez conejo (Siganus canaliculatus) [15], han permitido demostrar que las ELOVL4 de peces también participan en el metabolismo de VLC-PUFA expresado en tejidos como el ojo, las gónadas y el cerebro. Estos resultados resaltan la relevancia del estudio de las elongasas ELOVL4 y de los VLC-PUFA en especies de peces cultivados, donde alteraciones en la capacidad visual - determinante en animales predadores como la mayor parte de especies de acuicultura -, problemas de infertilidad en reproductores, y disrupciones en el funcionamiento cerebral pueden afectar al rendimiento de la producción acuícola.

Desde un punto de vista meramente analítico, la detección y caracterización de los VLC-PUFA han sido escasamente exploradas. La mayor parte de las referencias consultadas aplican el acoplamiento GC-MS con fuente EI para el análisis de los VLC-PUFA derivatizados [16], principalmente en forma de sus ésteres metílicos (VLC-PUFA-MEs) [17]. Sin embargo, la alta fragmentación provocada por la fuente EI implica la pérdida total y/o parcial del $\mathrm{M}^{+\cdot}$ y genera el mismo espectro de masas para PUFA-MEs de las series $\omega 3$ y $\omega 6$ independientemente de la longitud de cadena [18]. Estos hechos, junto a la ausencia de patrones de referencia comercialmente disponibles, dificultan el 
proceso de identificación de los compuestos, lo que ha motivado el estudio de la aplicación del acoplamiento GC-MS con fuente APCI como alternativa instrumental para su análisis.

En este capítulo se explora el potencial del acoplamiento GC-APCI-QTOF MS para la detección e identificación de VLC-PUFA en la fracción de fosfatidilcolinas (PC) de retinas de diferentes especies cultivadas. Como se expone a lo largo del artículo científico IV, en primer lugar, se lleva a cabo un estudio del comportamiento espectrométrico de los ésteres metílicos de ácidos grasos saturados y LC-PUFA para los cuales se dispone de estándares de referencia. A partir de este estudio, mediante herramientas estadísticas, se genera un modelo que permite diferenciar las series $\omega 3$ de las $\omega 6$ en base a sus patrones de fragmentación y se aplica al análisis de muestras reales. Por último, con el fin de confirmar la identidad de los compuestos detectados y validar la estrategia estadística de identificación, se lleva a cabo el análisis de diferentes experimentos de expresión heteróloga, es decir, se analizan los productos de elongación in vitro de diferentes LC-PUFA generados por la elongasa ELOVL4. 



\subsection{Artículo científico IV}

Analytica Chimica Acta 1051 (2019) 103-109

Identification of very long-chain ( $>\mathrm{C}_{24}$ ) fatty acid methyl esters using gas chromatography coupled to quadrupole/time-of-flight mass spectrometry with atmospheric pressure chemical ionization source

B. Garlito ${ }^{a}$, T. Portolés ${ }^{a}{ }^{*}$, W.M.A. Niessen ${ }^{\text {b }}$, J.C. Navarro ${ }^{c, d}$, F. Hontoria ${ }^{c}{ }^{d}$, Ó. Monroig ${ }^{e}$, I. Varó ${ }^{\mathrm{C} d}, \mathrm{R}$. Serrano ${ }^{\mathrm{a}, \mathrm{d}}$

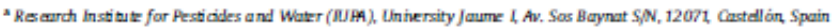

bypher Massipec, Margrietstraat 34, 2215 HJ. Vaarhaut the Netherlends

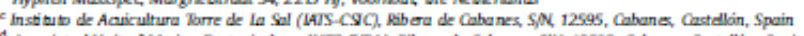

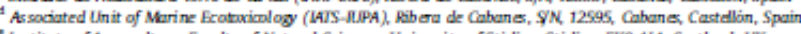

- Institut of Aquaculture, Foculty of Natural Soiences, Univessity of Stirling, Stirling, FK9 4LA, Scotland, UK

H I G H L I G H T S

- First application of CC-APCL-QTOF MS for detemination of VLC-PUFA methyl esters.

- Accurate mass $[\mathrm{M}+\mathrm{H}]^{+}$in $\mathrm{APC}$ spectrum: additional value for confdent identification

- Reliable identification of VLC-PUFAs without the need of reference standards.

- Development of ion ratio procedure to distinguish among $\omega 3$ and w6 congeners.

- A step forward to the knowledge of

the metabolism of these compounds.

A R T I C L E I N F O

\section{Artide histary:}

Received 16 February 2018

Received in revised form

30 October 2018

Accepted 1 November 2018

Available online 5 Novernber 2018

\section{Kegwords:}

Gaschromatography

Quadrupole time-of- flight mass

spectrametry

Atmos pheric pressure chemical ionizabion

source

Very lang-chain polyursaturated fatty aids
G R A P H I A L A BSTRACT

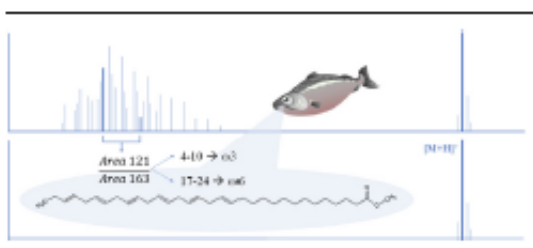

A B S T R A C T

Gas chromatography coupled to a quadrupole time-of-flight mass analyzer (QTOF) with an atmospheric pressure chemical ionization (APCI) source has been tested to study the ionization and mass spectrometric behavior of bong-chain and very long-chain polyunsaturated fatty acids (LC-PUFAs, C 18 -24: V.CPUFAs, $\left.>\mathrm{C}_{24}\right)$. The protonated molecule $\left([\mathrm{M}+\mathrm{H})^{+}\right)_{\text {. }}$ measured at accurate mass became the base peak of the spectrum for all the studied compounds and was promoted by the addition of water into the source This fact overcame the existing difficulties for the identification of VC-PUFAs when using an electron ionization source (EI). The extensive fragmentation of PUFAs in this source is the ma in drawback due to the fact that since reference standards are not commercially available, final identification relies on retention time estimation. The application of CC-APCLOTOF to the screening of lipid extracts from the eyes of different fish species added confidence to the identification of several VLC-PUFAs. Further investigation of ion ratios allowed to predict the position of key double bonds enabling the classification of VIC-PUFAs as $\omega 3$ or w6 compounds. VIC-PUFAs spectra found in biological samples were compared to those obtained from corresponding peaks found in heterologous expression experiments of fish's Elovil.

\footnotetext{
- Corresponding author

E-mail ad dress: tportalewujies (I Portolés)
}

https://daiorg/10.1016 jaca201811001

$0003-2670$ is 2018 Elkevier BV. All rights reserved 
Analytica Chimica Acta 1051 (2019) 103-109

Identification of very long-chain ( $>\mathrm{C}_{24}$ ) fatty acid methyl esters using gas chromatography coupled to quadrupole/time-of-flight mass spectrometry with atmospheric pressure chemical ionization source

B. Garlito ${ }^{\text {a }}$, T. Portolés ${ }^{\text {a, }}$, W.M.A. Niessen ${ }^{\text {b }}$, J.C. Navarro ${ }^{\text {c, d }}$, F. Hontoria ${ }^{\mathrm{c}, \mathrm{d}}$, Ó. Monroig e ${ }^{\mathrm{e}}$ I. Varó ${ }^{\mathrm{c}, \mathrm{d}}, \mathrm{R}$. Serrano ${ }^{\mathrm{a}, \mathrm{d}}$

${ }^{a}$ Research Institute for Pesticides and Water (IUPA), Avda. Sos Baynat, s/n, University Jaume I, 12071 Castellón, Spain

${ }^{\mathrm{b}}$ Hyphen MassSpec, Margrietstraat 34, 2215 HJ, Voorhout, the Netherlands ${ }^{\mathrm{c}}$ Instituto de Acuicultura Torre de La Sal (IATS-CSIC), Ribera de Cabanes, S/N, 12595, Cabanes, Castellón, Spain

${ }^{\mathrm{d}}$ Associated Unit of Marine Ecotoxicology (IATS-IUPA), Ribera de Cabanes, S/N, 12595, Cabanes, Castellón, Spain

${ }^{\mathrm{e}}$ Institute of Aquaculture, Faculty of Natural Sciences, University of Stirling, Stirling, FK9 4LA, Scotland, UK

\section{Abstract}

Gas chromatography coupled to a quadrupole time-of-flight mass analyzer (QTOF) with an atmospheric pressure chemical ionization (APCI) source has been tested to study the ionization and mass spectrometric behavior of longchain and very long-chain polyunsaturated fatty acids (LC-PUFAs, C18-24; VLC-PUFAs, >C24). The protonated molecule $\left([\mathrm{M}+\mathrm{H}]^{+}\right)$, measured at accurate mass, became the base peak of the spectrum for all the studied compounds and was promoted by the addition of water into the source. This fact overcame the existing difficulties for the identification of VLC-PUFAs 
when using an electron ionization source (EI). The extensive fragmentation of PUFAs in this source is the main drawback due to the fact that since reference standards are not commercially available, final identification relies on retention time estimation. The application of GC-APCI-QTOF to the screening of lipid extracts from the eyes of different fish species added confidence to the identification of several VLC-PUFAs. Further investigation of ion ratios allowed to predict the position of key double bonds enabling the classification of VLC-PUFAs as $\omega 3$ or $\omega 6$ compounds. VLC-PUFAs spectra found in biological samples were compared to those obtained from corresponding peaks found in heterologous expression experiments of fish's Elovl4.

\section{Highlights}

- First application of GC-APCI-QTOF MS for determination of VLC-PUFA methyl esters. Accurate mass $[\mathrm{M}+\mathrm{H}]^{+}$in APCI spectrum: additional value for confident identification. Reliable identification of VLC-PUFAs without the need of reference standards. Development of ion ratio procedure to distinguish among $\omega 3$ and $\omega 6$ congeners. A step forward to the knowledge of the metabolism of these compounds.

\section{Keywords}

Gas chromatography, Quadrupole time-of-flight mass spectrometry, atmospheric pressure chemical ionization source, Very long-chain polyunsaturated fatty acids. 


\section{Graphical abstract}

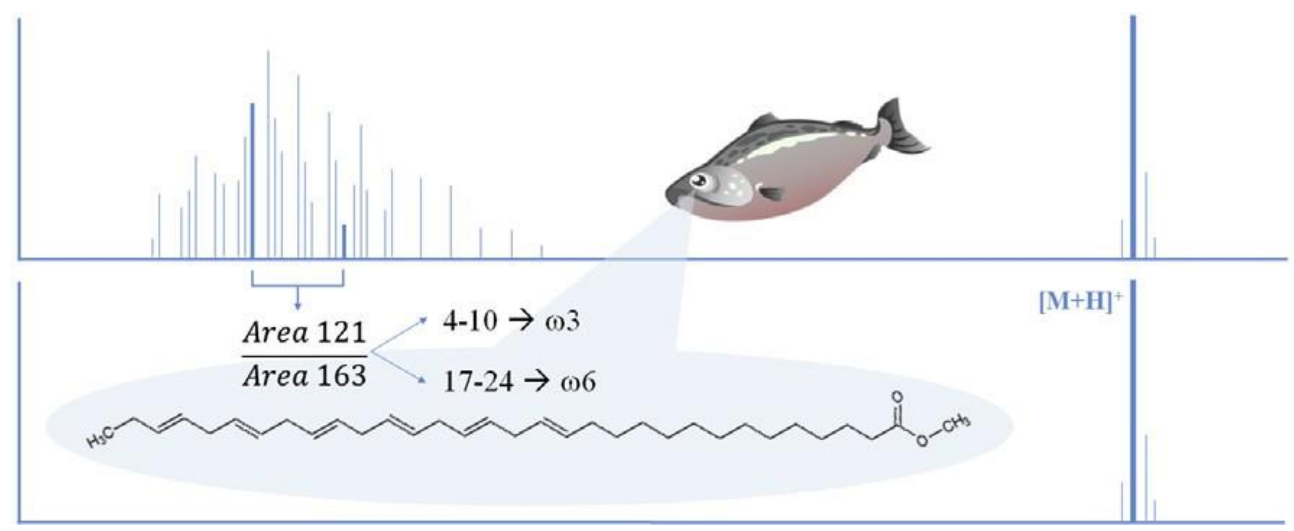




\section{INTRODUCTION}

Fatty acids (FAs), besides being a source of energy, are essential compounds involved in different physiological and metabolic processes, like cell membrane formation or signal transduction, that ensure the correct cellular functioning [1]. Among FAs, certain long-chain $\left(\mathrm{C}_{18-24}\right)$ polyunsaturated fatty

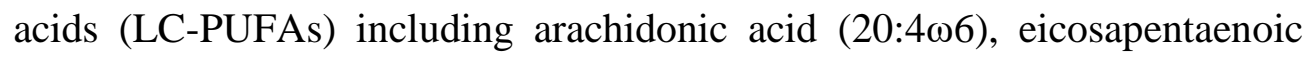

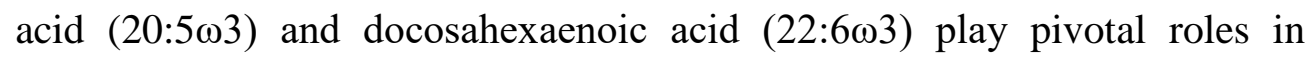
inflammatory response and function and in development of the central nervous system [2]. Several studies have demonstrated the influence of LC-PUFAs in neural development, neurodegenerative diseases, and visual system in mammals $[3,4]$.

Besides, the very long-chain $\left(>\mathrm{C}_{24}\right)$ polyunsaturated fatty acids (VLCPUFAs), biosynthesized in vertebrates by FA elongase enzymes such as Elov14 [5], have been regarded as essential for cognitive development, retinal function and reproductive processes [6-10]. Consequently, VLC-PUFAs are typically found in low concentrations in specific lipid classes such as phosphatidylcholine (PC), sphingomyelin and ceramides in brain, retina and gonads of vertebrates [11], and their importance has been related to their structure combining a proximal carboxylic region similar to saturated FAs and a distal region with PUFA character [8]. In addition to being present in specific lipid classes from certain tissues in very small amounts compared to their shorter chain counterparts, the lack of standards and references in mass spectrometry libraries have involved an analytical challenge for their determination and characterization.

Liquid and gas chromatography (LC and GC) coupled to mass spectrometry 
(MS) have been the techniques chosen to carry out both quantitative and qualitative analysis. On the one hand, LC-MS techniques based on electrospray ionization (ESI) or atmospheric pressure chemical ionization (APCI) have been commonly applied for the analysis of lipid species containing VLC PUFAs [8]. To achieve this, LC in normal and reversed phase are used but long chromatographic runs are required to achieve good chromatographic separation between polar species $[12,13]$. In order to facilitate the quantitative analysis of total VLC-PUFAs, hydrolysis must be performed leading to LC-ESI-MS in negative-ion mode the required technique. However, the drawbacks of low specificity in the negative-ion MS detection mode and requirement of the post-column addition of a cationizating agent after acidic chromatographic separation have hindered a simple way of FA analysis. Thus, derivatization of FA must be finally applied to facilitate their analysis by LC-ESI-MS in positive-ion mode [14].

On the other hand, while a derivatization step is also required, GC is the most frequently used technique in this field. To improve the separation performance, comprehensive two dimensional gas chromatography $(\mathrm{GC} \times \mathrm{GC})$ has also been applied to clarify the identity of fatty acid isomers [15]. Although selective GC stationary phases like polyethylene glycols or cyanopropyl silicones (medium-high polarity) are widely applied for the analysis of FAMEs $(\mathrm{C}<24)$, for the study of VLC-PUFA 5\%-(phenyl)methylpolysiloxane columns are more convenient as the applicable upper temperature limit $\left(350^{\circ} \mathrm{C}\right)$ is higher than the selective ones $\left(260^{\circ} \mathrm{C}\right)$. Under these conditions, VLC-PUFA $(\mathrm{C}>24)$ can be analyzed avoiding column degradation. GC-MS with electron ionization (EI) is frequently applied for the analysis of VLC-PUFAs [16] since it provides complete information about the fragmentation patterns of FA derivatives. Among others, methyl esters 
(FAMEs) are commonly used in FA analysis [17]. However, the extensive fragmentation of FAMEs in EI source involves the partial or total loss of the highly diagnostic molecular ion $\left(\mathrm{M}^{+\bullet}\right)$ and generates the same EI spectra for unsaturated FAMEs ( $\omega 6$ or $\omega 3$ ) with different chain length [18]. This fact, together with the absence of reference standards, hinders the identification process of VLC-PUFAs. In this context, APCI combined with GC-MS instruments has revealed as a useful alternative to EI. As it has been demonstrated in several fields [19-24], the soft and universal ionization in this source provides abundant $\mathrm{M}^{+\bullet}$ and/or $[\mathrm{M}+\mathrm{H}]^{+}$in the mass spectra, thus substantially improving the identification capability, as well as enhancing sensitivity and selectivity for the detection of analytes in the samples [25,26]. Under these circumstances, the use of GC-APCI-QTOF MS will add confidence to the identification of VLC-PUFA.

Since their detection in bovine retinas by Aveldaño et al. in 1987 [27], the study of VLC-PUFAs has been mainly focused on mammals [9,11,12,28,29]. However, the detection and characterization of these compounds in fish has been scantily studied despite being the main source of $\omega 3$ LC-PUFAs in human's diet [30]. Studies in fish have focused on elucidating the molecular mechanisms underlying the biosynthesis of VLC-PUFAs, particularly the roles that elongase enzymes such as Elovl4 play in these metabolic pathways $[2,31]$.

The aim of this work is the development of a reliable analytical methodology for detection and identification of VLC-PUFAs, for which no commercially available standards exist, in the PC fraction of lipid extracts from the eyes of different fish species. The potential of GC-APCI-QTOF MS to provide accurate mass measurement of intact $\mathrm{M}^{+\bullet}$ and/or $[\mathrm{M}+\mathrm{H}]^{+}$, was considered to 
add confidence in the identification step. For this purpose, a range of commercially available saturated and polyunsaturated LC-PUFA methyl esters were analyzed by GC-APCI-QTOF MS and their ionization and fragmentation behavior was studied. Additionally, relationships between the fragmentation patterns and FAME structures have been studied in order to differentiate $\omega 3$ from $\omega 6$ VLC-PUFAs' series without the need of reference standards. As a final step, in order to confirm the identity of detected compounds, heterologous expression experiments were carried out. To the best of our knowledge, GC-APCI-QTOF MS has not been applied for the determination of VLC-PUFA methyl esters yet.

\section{EXPERIMENTAL}

\subsection{Standard compounds, solvents and reagents}

Methyl stearate (18:0-ME), methyl arachidate (20:0-ME), methyl behenate (22:0-ME) and methyl tetracosanoate (24:0-ME) standards were purchased from Fluka (Zwijndrecht, The Netherlands). Methyl hexacosanoate (26:0$\mathrm{ME}$ ), methyl octacosanoate (28:0-ME) and methyl triacontanoate (30:0-ME) standards were purchased from Dr. Ehrenstorfer (Augsburg, Germany).

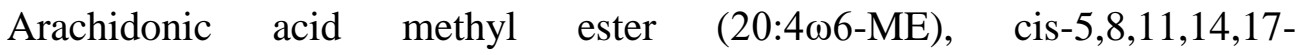
eicosapentaenoic acid methyl ester (20:503-ME), cis-7,10,13,16-

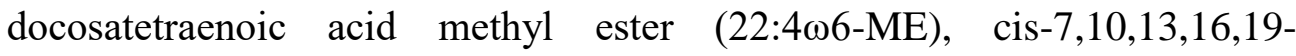

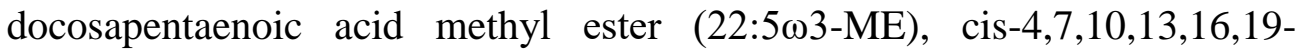

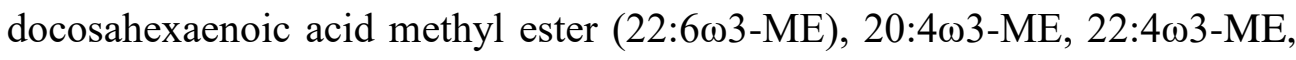
and 24:5 03 standards were purchased from Supelco (Bellefonte, PA, USA).

B. Garlito et al., Analytica Chimica Acta 1051 (2019) 103-109 
Stock solutions (around $500 \mu \mathrm{g} \cdot \mathrm{mL}^{-1}$ and $1 \mu \mathrm{g} \cdot \mathrm{mL}^{-1}$ for 24:0-ME and 26:0ME) were prepared by dissolving solid reference standards in hexane or by diluting reference standard solutions in hexane and subsequently stored in a freezer at $-20{ }^{\circ} \mathrm{C}$ under a $\mathrm{N}_{2}$ atmosphere. Working solutions were prepared by diluting stock solutions in hexane.

Hexane (ultra-trace quality) was purchased from Scharlab (Barcelona, Spain). Chloroform $\left(\mathrm{CHCl}_{3}\right)$, diethyl ether and toluene were purchased from Merck Millipore (Darmstadt, Germany). Methanol (MeOH) was purchased from VWR (Radnor, PA, USA). Sulfuric acid, glacial acetic acid and potassium chloride $(\mathrm{KCl})$ were purchased from Panreac (Castellar del Vallés, Barcelona, Spain). Iodine and butylated hydroxytoluene (BHT, content >99\%), used as antioxidant, were purchased from Sigma Aldrich (St. Louis, MO, USA). All reagents were analytical grade. HPLC-grade water was obtained by purifying double distilled water in a Milli-Q Gradient A10 system (Millipore, Bedford, MA, USA).

\subsection{Samples}

Fish eyes

Twelve eyes from adult specimens of fish species including the European seabass (2), gilthead seabream (1), Atlantic salmon (1) and Senegalese sole (8) were dissected and cleaned from other tissues. Next, the crystalline lens was removed and stored at $-20^{\circ} \mathrm{C}$ for further treatment. 


\section{Elongated fatty acids by Elov14 protein}

Further biological samples containing VLC-PUFAs were generated by expressing the coding region of the Atlantic salmon Elovl4 in yeast Saccharomyces cerevisiae which was grown in the presence of one of the following polyunsaturated fatty acid (PUFA) substrates: 20:4 $22: 5 \omega 3,22: 6 \omega 3,24: 5 \omega 3$. A previous study confirmed that the Atlantic salmon Elovl4 could efficiently elongate some of these PUFA substrates to produce polyenes up to 36 carbons [32]. After $48 \mathrm{~h}$, yeast samples were harvested and washed twice with double distilled water and kept at $-20{ }^{\circ} \mathrm{C}$ until further treatment [32]. Given that Elovl4 enzymes add 2-carbon units to FA substrates [33], all these PUFA substrates provided a set of step-wise elongation products that could be easily identified in the chromatogram since both FA substrates and products are absent in yeast.

\subsection{Sample treatment}

Total lipids were extracted according to the method of Folch et al. [34]. Briefly, samples (fish eyes and yeast) were homogenized in $\mathrm{CHCl}_{3}: \mathrm{MeOH}$ $(2: 1, \mathrm{v} / \mathrm{v})$ with BHT $(0.01 \%, \mathrm{w} / \mathrm{v})$. After addition of $0.25 \%(\mathrm{v}: \mathrm{v})$ aqueous solution of $\mathrm{KCl}(0.88 \%$, w/v), the lower organic phase was filtered $(70 \mu \mathrm{m}$ Whatman filter paper), evaporated to dryness under a stream of nitrogen and kept in desiccator overnight. The extracts were then weighed to determine the total amount of lipids, redissolved in $\mathrm{CHCl}_{3}: \mathrm{MeOH}(2: 1)(10 \mathrm{mg} / \mathrm{mL})$ and stored at $-20^{\circ} \mathrm{C}$.

Phospholipid classes were separated following the method developed by 
Olsen et al. [35] consisting in $20 \mathrm{~cm} \times 20 \mathrm{~cm}$ TLC plates (Silica gel G 60 (Merck, Darmstadt, Germany) run in a polar solvent system of methyl acetate:isopropanol: $\mathrm{CHCl}_{3}: \mathrm{MeOH}: 0.25 \% \quad(\mathrm{w} / \mathrm{v}) \quad \mathrm{KCl} \quad(25: 25: 25: 10: 9$ by volume). A well known Artemia nauplii extract [36] run in parallel to the samples allowed the location of the PC fraction on the plates after using a $1 \%$ (w/v) iodine solution in $\mathrm{CHCl}_{3}$ for lipid dying. PC spots were scrapped off and submitted to acid-catalyzed transesterification [37]. Resulting fatty acid methyl esters (FAMEs) were stored at $-20{ }^{\circ} \mathrm{C}$ in hexane/BHT $(0.01 \%)$ under nitrogen, until chromatographic analysis.

\subsection{Instrumental}

\section{$\underline{\text { GC-APCI-(Q)TOF MS }}$}

An Agilent $7890 \mathrm{~N}$ gas chromatograph (Palo Alto, CA, USA) equipped with an Agilent 7683 autosampler was coupled to a quadrupole orthogonal acceleration time-of-flight mass spectrometer, Xevo G2 QTOF (Waters Corporation, Manchester, UK), operated in APCI mode. A fused silica HP$5 \mathrm{MS}$ capillary column with a length of $30 \mathrm{~m} \times 0.25 \mathrm{~mm}$ i.d. and a film thickness of $0.25 \mu \mathrm{m}$ with a $1 \mathrm{~m} \times 0.25 \mathrm{~mm}$ i.d. deactivated post-column $(\mathrm{J} \& \mathrm{~W}$ Scientific, Folson, CA, USA) was used for GC separation. The oven temperature was programmed as follows: $60^{\circ} \mathrm{C}(1 \mathrm{~min}) ; 40^{\circ} \mathrm{C} / \mathrm{min}$ to $180^{\circ} \mathrm{C}$; $10{ }^{\circ} \mathrm{C} / \mathrm{min}$ to $320^{\circ} \mathrm{C}$ (4 min). Pulsed splitless (30 psi) injections of $1 \mu \mathrm{L}$ were carried out at $280^{\circ} \mathrm{C}$ with a splitless time of $1 \mathrm{~min}$. Helium 99.999\% (Praxair, Spain) was used as carrier gas at a flow of $2 \mathrm{~mL} \cdot \mathrm{min}^{-1}$.

The interface and ionization source temperatures were set to $320{ }^{\circ} \mathrm{C}$ and 150 
${ }^{\circ} \mathrm{C}$, respectively. $\mathrm{N}_{2}$ was used as auxiliary gas at $175 \mathrm{~L} \cdot \mathrm{h}^{-1}$, as cone gas at 25 $\mathrm{L} \cdot \mathrm{h}^{-1}$ and as make-up gas at $300 \mathrm{~mL} \cdot \mathrm{min}^{-1}$. The APCI corona discharge pin was operated at $1.2 \mu \mathrm{A}$ and the cone voltage was set to $20 \mathrm{~V}$.

The QTOF was operated at 2.5 spectra $\cdot \mathrm{s}^{-1}$ acquiring the mass range $m / z$ 50650. The TOF MS resolution was approximately 15,000 (FWHM) at $m / z 264$. Acquisition was done in $\mathrm{MS}^{\mathrm{E}}$ mode in which two alternating acquisition functions with different collision energies were generated: the low-energy (LE) function, selecting a collision energy of $4 \mathrm{eV}$ to avoid or minimize fragmentation, and the high-energy (HE) function, with a collision energy ramp ranging from 25 to $40 \mathrm{eV}$ to obtain a greater range of fragment ions.

Perfluorotributylamine (Sigma Aldrich, Madrid, Spain) was used for the daily mass calibration. Internal calibration was performed using a background ion from the GC-column bleed as lock mass (protonated molecule of hexamethylcyclotrisiloxane, $m / z$ 223.0642).

In order to work under proton transfer conditions, an uncapped vial containing water was placed in a designed holder into the APCI source door to enhance protonation. MS data were acquired in centroid mode and processed by the ChromaLynx XS application manager (within MassLynx v4.1; Waters). Mass-Fragment software (Waters) was used for mass spectra interpretation.

\section{RESULTS AND DISCUSSION}

\subsection{Ionization behavior of FAMEs}

The ionization behavior was tested using all commercially available FAME 
standards with a focus on their differences in the degree of unsaturation and position of the last double bond: saturated (18:0-ME, 20:0-ME, 22:0ME,24:0-ME, 26:0-ME, 28:0-ME and 30:0-ME) and unsaturated (20:4

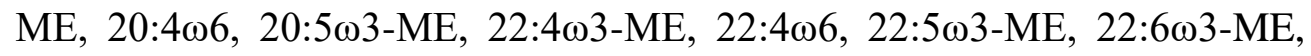
and 24:5 13 -ME). As it has been described in previous studies, two ionization mechanisms can take place simultaneously in the APCI source: charge transfer promoting the formation of $\mathrm{M}^{+\bullet}$ and/or protonation [38]. In many cases, protonation is directly produced by the water traces present in the $\mathrm{N}_{2}$ supply. However, it can be enhanced using protic solvents as modifier [20]. Some experiments regarding analyte ionization were made in order to evaluate the effect of the addition of modifiers in the source.

Despite no protic modifier was initially added into the source, the protonated molecule $[\mathrm{M}+\mathrm{H}]^{+}$was the base peak in the spectrum for all analytes. For saturated FAMEs, the molecular ion $\mathrm{M}^{+\bullet}$ was also formed from 39 to $86 \%$, showing a higher tendency of protonation when the number of carbon atoms decreased (see Figure 1a up). In the case of $\omega 3$ and $\omega 6$ FAMEs, $\mathrm{M}^{+\bullet}$ was generated from 40 to $75 \%$ and 23 to $71 \%$, respectively, showing a higher tendency of protonation when the number of carbon atoms decreased and the unsaturation degree increased (see Figure 1b-c up)

Taking into account the proneness of FAMEs to protonation, a subsequent experiment using water as modifier in the source was carried out. In this way, the proton transfer mechanism was enhanced, decreasing the relative abundance of $\mathrm{M}^{+\bullet}$ (Figure $\mathbf{1}$ down). $\mathrm{M}^{+\bullet}$ still appeared in the spectra, but only in a percentage among 7-10\% for saturated FAMEs (with the same protonation tendency as for charge transfer conditions), 8-12\% for $\omega 6$ and $7-9 \%$ for $\omega 3$ FAMEs showing higher protonation affinity of the smallest FAMEs with 
highest degree of unsaturation. Therefore, because of both the better sensitivity of protonated molecule and higher spectral purity, it was decided to use water as modifier for further experiments.

As a consequence of the soft ionization character of the APCI source, low insource fragmentation of FAMEs was observed if compared with their corresponding EI spectra taken from NIST library. As it has been reported in other studies, EI spectra of saturated FAMEs are dominated by the ion with $\mathrm{m} / \mathrm{z} 74\left[\mathrm{CH}_{2} \mathrm{C}(\mathrm{OH}) \mathrm{OCH}_{3}\right]^{+\bullet}$ resulting from a McLafferty rearrangement (Figure 2a), whereas the ion with $m / z 79\left[\mathrm{C}_{6} \mathrm{H}_{7}\right]^{+}$is usually the base peak in mass spectra of FAMEs with three or more methylene-interrupted double bonds (Figure 2c) [17]. Exploring the APCI spectra of saturated FAMEs, no in-source fragment ions were observed. Thus, $[\mathrm{M}+\mathrm{H}]^{+}$is completely preserved (Figure 2b). Regarding polyunsaturated $\omega 6$ and $\omega 3$ FAMEs, all of them exhibited $\left[\mathrm{M}+\mathrm{H}-\mathrm{CH}_{3} \mathrm{OH}\right]^{+}$in-source fragments with relative abundances between $4-11 \%$ and $2-6 \%$, respectively. In addition, less abundant $[\mathrm{M}+\mathrm{H}-$ $\left.\mathrm{CH}_{3} \mathrm{OH}-\mathrm{H}_{2} \mathrm{O}\right]^{+}$fragments were also found for all polyunsaturated FAMEs (Figure 2d).
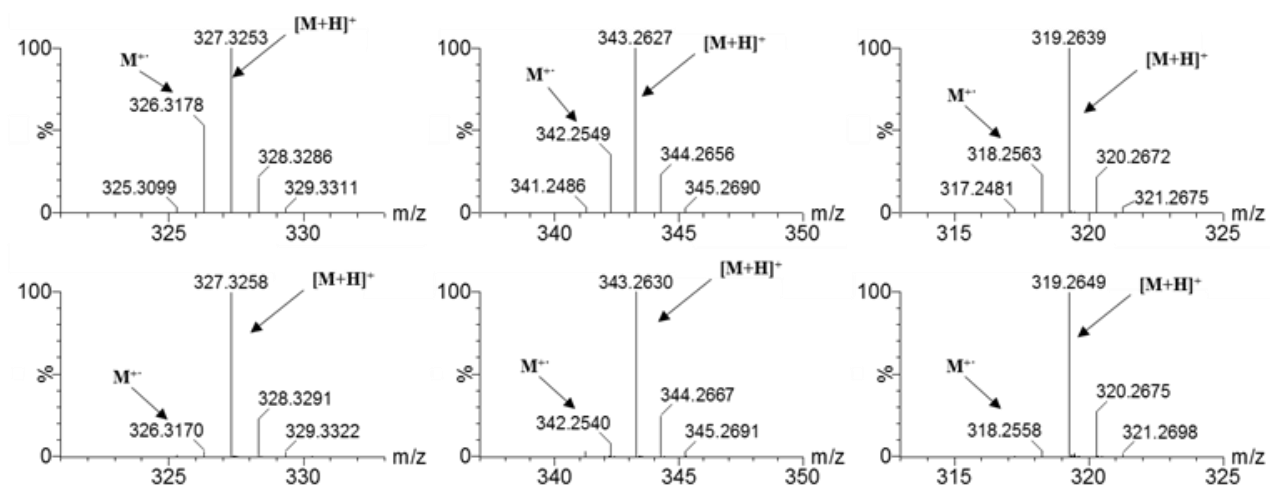

(a)

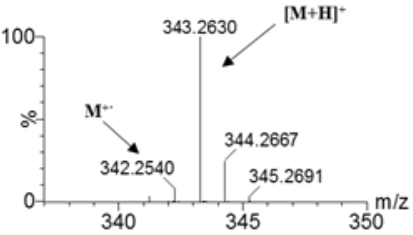

(b)

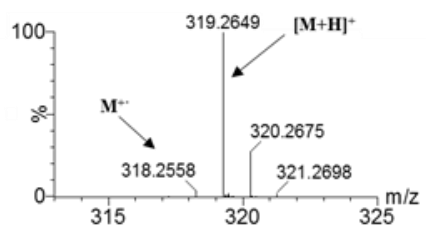

(c)

Figure 1: APCI spectra at the LE function of (a) 20:0-ME (saturated); (b)

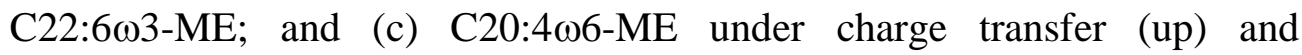
protonation conditions (down). 
$\mathrm{APCl}$
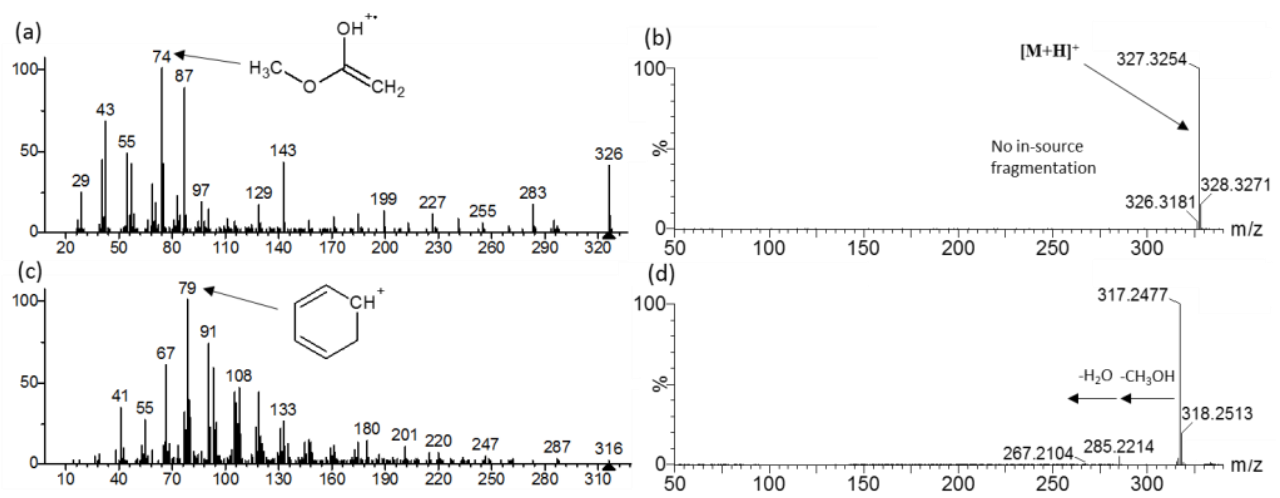

Figure 2: Comparison of the in-source fragmentation for arachidic acid ME (up) and C20:5 $13-\mathrm{ME}$ (down) in EI (left) and APCI (right) sources.

\subsection{Fragmentation behavior of FAMEs}

FAMEs share a common methyl ester group. The oxygen atoms are the only structural features with lone electron pairs, thus being the most feasible sites for protonation. Taking into account the proton affinity of the carbonyl and methyl ether groups, the expected protonation site would be the oxygen atom of the carbonyl function. However, the degree of unsaturation plays an important role in ionization/fragmentation behavior, as is described below.

\subsubsection{Group I. Saturated FAMEs}

All saturated FAMEs showed $[\mathrm{M}+\mathrm{H}]^{+}$as the base peak of the spectrum at LE due to the protonation of the carbonyl function. At HE conditions, the spectra are characterized by the presence of the ion with $m / z, 103.0759\left(\mathrm{C}_{5} \mathrm{H}_{11} \mathrm{O}_{2}{ }^{+}\right)$as the base peak, with a subsequent neutral loss of $\mathrm{HCOOH}$ producing the fragment ion with $m / z, 57.0704\left(\mathrm{C}_{4} \mathrm{H}_{9}{ }^{+}\right)$. For this class of compounds, although being unusual, apparently charge-remote fragmentation occurs and series of 
$\mathrm{C}_{2 \mathrm{n}} \mathrm{H}_{4 \mathrm{n}}$ losses from the hydrocarbon chain are observed.

\subsubsection{Group II. $\omega 6$ and $\omega 3$ FAMEs}

All $\omega 6$ and $\omega 3$ FAMEs showed a common fragmentation pathway showing fragment ions with the same $\mathrm{m} / \mathrm{z}$, irrespective the $\omega 6$ or $\omega 3$ character. After studying it at the HE function, none of the fragment ions by itself was specific for either the $\omega 3$ or the $\omega 6$, as in most cases only abundance differences seemed to be observed. This constitutes an inconvenience in the characterization of VLC-PUFAs for which no reference standards are (commercially) available. The presence of the $[\mathrm{M}+\mathrm{H}]^{+}$in the LE spectrum together with the fragmentation information of the HE spectrum allows to tentatively identify the VLC-PUFA in terms of carbon chain length and the degree of unsaturation. At this point, it was considered to use of abundance ratios to distinguish between the $\omega 6$ and $\omega 3$ compounds. For that, all the spectral information available for the commercial reference standards was used to create a data matrix that contained the abundance for each $\mathrm{m} / \mathrm{z}$ ion. Data were normalized to the ion with $\mathrm{m} / \mathrm{z}, 121$ which was the base peak of

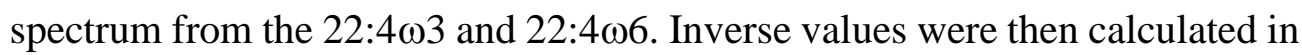
order to work with values above 1. Among them, there were standards with different chain lengths $\left(\mathrm{C}_{20}-\mathrm{C}_{24}\right)$ and different degrees of unsaturation $(4,5$ and 6) for $\omega 3$ while only $\mathrm{C}_{20}$ and $\mathrm{C}_{22}$ with a degree of unsaturation of 4 were available for $\omega 6$.

Firstly, considering a completely unbiased analysis, a principal component analysis (PCA) was applied over the training data matrix. Figure 3a illustrates the PCA obtained in which a rough distinction between $\omega 3$ and $\omega 6$ can be appreciated. The next step consisted in performing an orthogonal partial least 
squares-discriminant analysis (OPLS-DA), which considers additional information about the two groups during classification. Thus, an OPLS-DA was applied to construct a statistical model that highlight differences in ion ratios between the two groups. As it can be seen, the OPLS-DA analysis separated the two groups of samples. For this purpose, an S-Plot graphic for $\omega 3$ vs $\omega 6$ was obtained (Figure 3b) and studied looking for endpoints. Theoretically, in an S-Plot the points with a p-corr value between 0.9 and 1 are closely related to the compounds characterizing the samples of one group, which constitute important class markers. According to this, only one marker (ion ratio for the ions with $\mathrm{m} / \mathrm{z} 121$ and 163) was selected. Returning to the data, we could observe that $\omega 3$ compounds used for the model construction presented ion ratios in the range of 4-10 while $\omega 6$ were found to be in the range of 17-24. Thus, this ion-ratio procedure was used for further experiments.

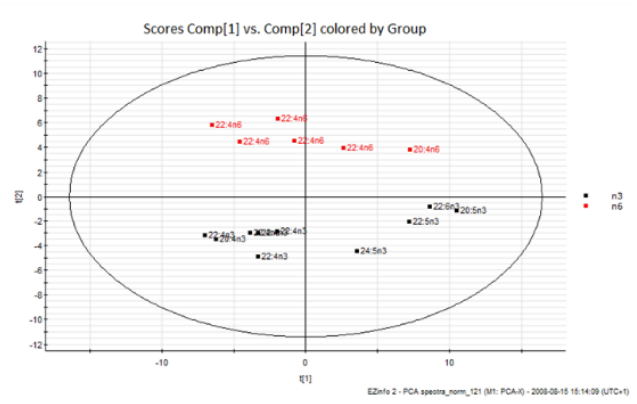

(a)

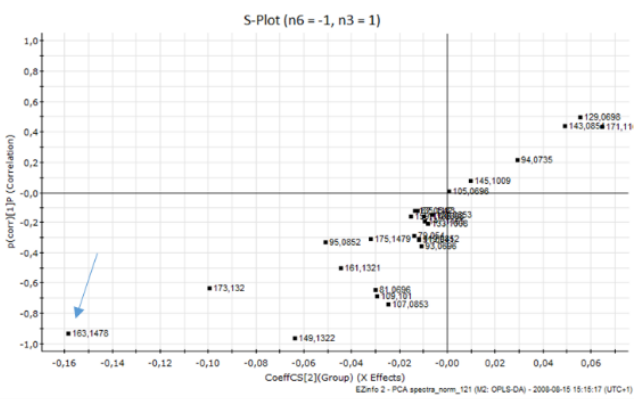

(b)

Figure 3: (a) PCA plot corresponding to the reference standards analyzed to create the model; (b) SPLOTs $\omega-3$ versus $\omega-6$.

\subsection{Analysis of adult fish eyes samples}

The system (GC-APCI-QTOF MS in $\mathrm{MS}^{\mathrm{E}}$ mode) was used for the eye extracts analysis. Data were processed using ChromaLynx XS software in 
combination with a homemade compound database that contained the elemental composition, retention time and fragments information previously obtained from the study with commercially available reference standards $\left(\mathrm{C}_{20}\right.$ $\mathrm{C}_{22}$ ). Additionally, this database was extended with those FAMEs reported in the literature, mainly VLC-PUFAs for which reference standards were not commercially available $\left(\mathrm{C}_{24}-\mathrm{C}_{34}\right)$, and whose reliable identification is considered an additional value given by GC-APCI-QTOF MS. The ChromaLynx XS application manager obtained eXtracted Ion Chromatograms (XICs) at LE and HE functions (0.02 Da window) for $\mathrm{m} / \mathrm{z}$ values corresponding to the theoretical exact masses of the protonated molecules and the fragments (if known), respectively.

Table 1 summarizes the positive findings of FAMEs detected in the fish eye samples analyzed from the different species. Detection was initially based on the presence of $[\mathrm{M}+\mathrm{H}]^{+}$in the LE function. Further investigation of fragment ions from the HE function together with the application of the ion-ratio procedure developed allowed their tentative identification. As an example, Figure 4 illustrates the detection and tentative identification of 32:6 $133-\mathrm{ME}$ in a gilthead sea bream eyes sample by GC-APCI-QTOF MS. The protonated molecule of 32:6-ME with $m / z, 483.4197\left(\mathrm{C}_{33} \mathrm{H}_{55} \mathrm{O}_{2}{ }^{+}\right)$was detected in the $\mathrm{LE}$ function with a mass error of $1.0 \mathrm{ppm}$. As the reference standard was not available, chemical structures for the most abundant fragment ions were suggested based on their accurate masses, using the Mass-Fragment software. All structures proposed for the fragments were compatible with the chemical structure of 32:6-ME making the identification even more reliable. At this point, the ion-ratio procedure developed was applied in order to decide whether it was $\omega 3$ or $\omega 6$. The ratio of $m / z, 121$ and $m / z 163$ was calculated to 


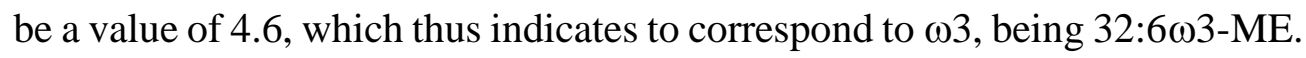

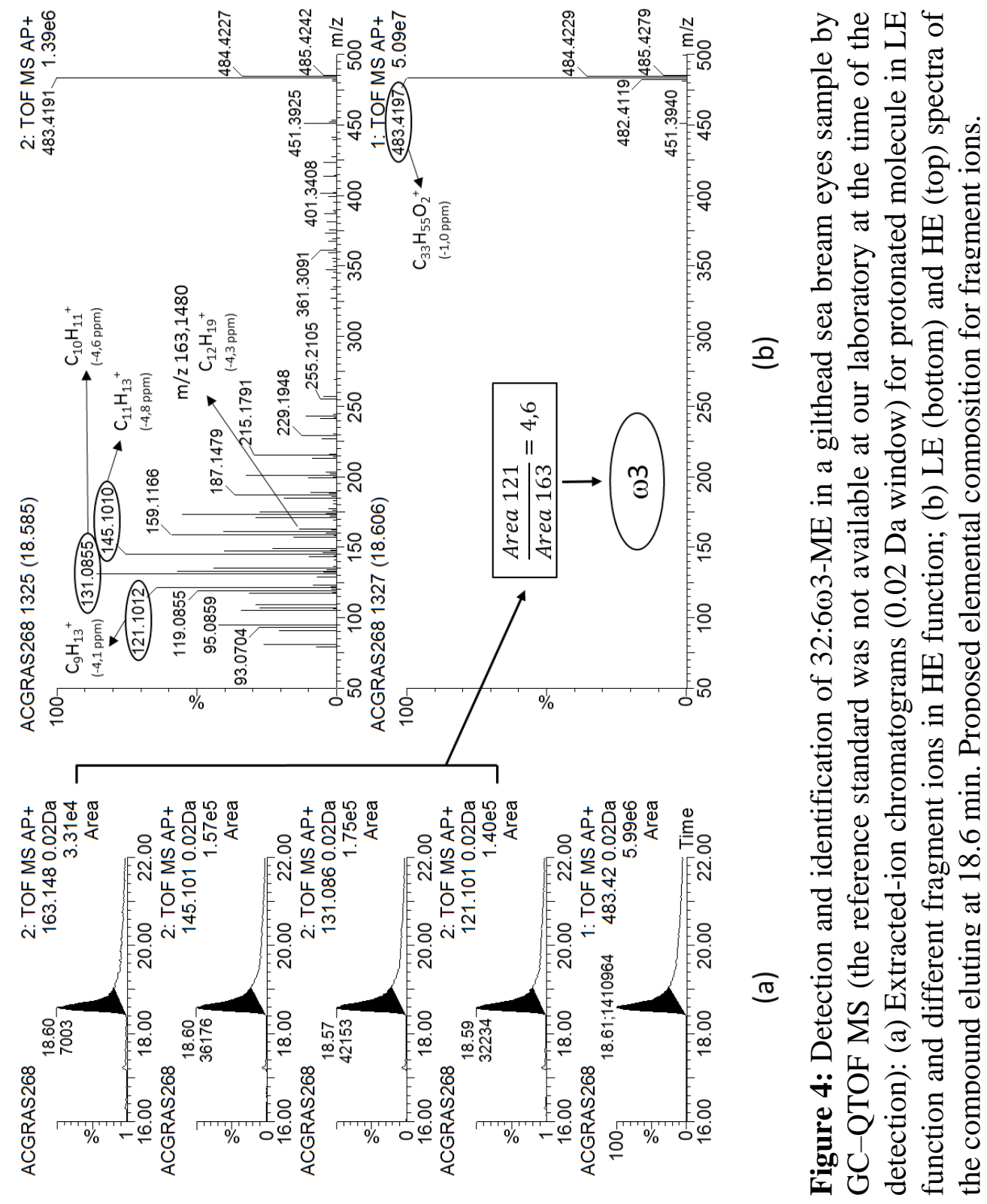


Table 1. List of PUFAs identified in the fish eye samples analyzed from the different species

\begin{tabular}{|c|c|c|c|c|}
\hline Compounds & $\begin{array}{c}\text { European } \\
\text { seabass }\end{array}$ & $\begin{array}{c}\text { Gilthead } \\
\text { seabream }\end{array}$ & $\begin{array}{c}\text { Senegalese } \\
\text { sole }\end{array}$ & $\begin{array}{c}\text { Atlantic } \\
\text { salmon }\end{array}$ \\
\hline $20: 4 \omega 6$ & $\checkmark$ & $\checkmark$ & $\checkmark$ & $\checkmark$ \\
\hline $20: 5 \omega 3$ & $\checkmark$ & $\checkmark$ & $\checkmark$ & $\checkmark$ \\
\hline $22: 6 \omega 3$ & $\checkmark$ & $\checkmark$ & $\checkmark$ & $\checkmark$ \\
\hline $22: 5 \omega 6$ & $\checkmark$ & $\checkmark$ & $\checkmark$ & $\checkmark$ \\
\hline $22: 5 \omega 3$ & $\checkmark$ & $\checkmark$ & $\checkmark$ & $\checkmark$ \\
\hline $24: 6 \omega 3$ & $\checkmark$ & $\checkmark$ & $\checkmark$ & $\checkmark$ \\
\hline $26: 6 \omega 3$ & $\checkmark$ & $\checkmark$ & & \\
\hline $28: 6 \omega 3$ & $\checkmark$ & $\checkmark$ & & \\
\hline $30: 6 \omega 3$ & $\checkmark$ & $\checkmark$ & $\checkmark$ & $\checkmark$ \\
\hline $32: 6 \omega 3$ & $\checkmark$ & $\checkmark$ & $\checkmark$ & \\
\hline $34: 6 \omega 3$ & $\checkmark$ & $\checkmark$ & & \\
\hline
\end{tabular}

\subsection{Analysis of heterologous expression experiments and validation of the ion-ratio procedure}

In order to confirm the identity of detected compounds and validate the developed ion-ratio procedure for the characterization of $\omega 3$ and $\omega 6$ VLCPUFAs, heterologous expression experiments were carried out in order to establish retention times for VLC-PUFAs and compare the obtained spectra. As it has been explained in the introduction, Elovl4 proteins enable the elongation of PUFAs including, among others, 20:4 $\omega 6$ (arachidonic acid),

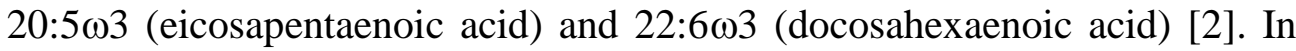




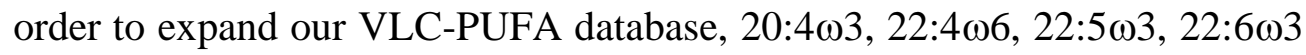
and 24:5 03 FAs were individually used as elongation substrates for the Atlantic salmon Elovl4, a protein that had previously shown elongase capacity towards all these compounds [32]. Figure 5 shows the XIC for the elongation

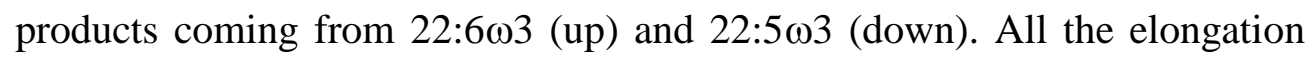
products and substrates were evaluated and the information obtained allowed the final identification of the expected compounds.

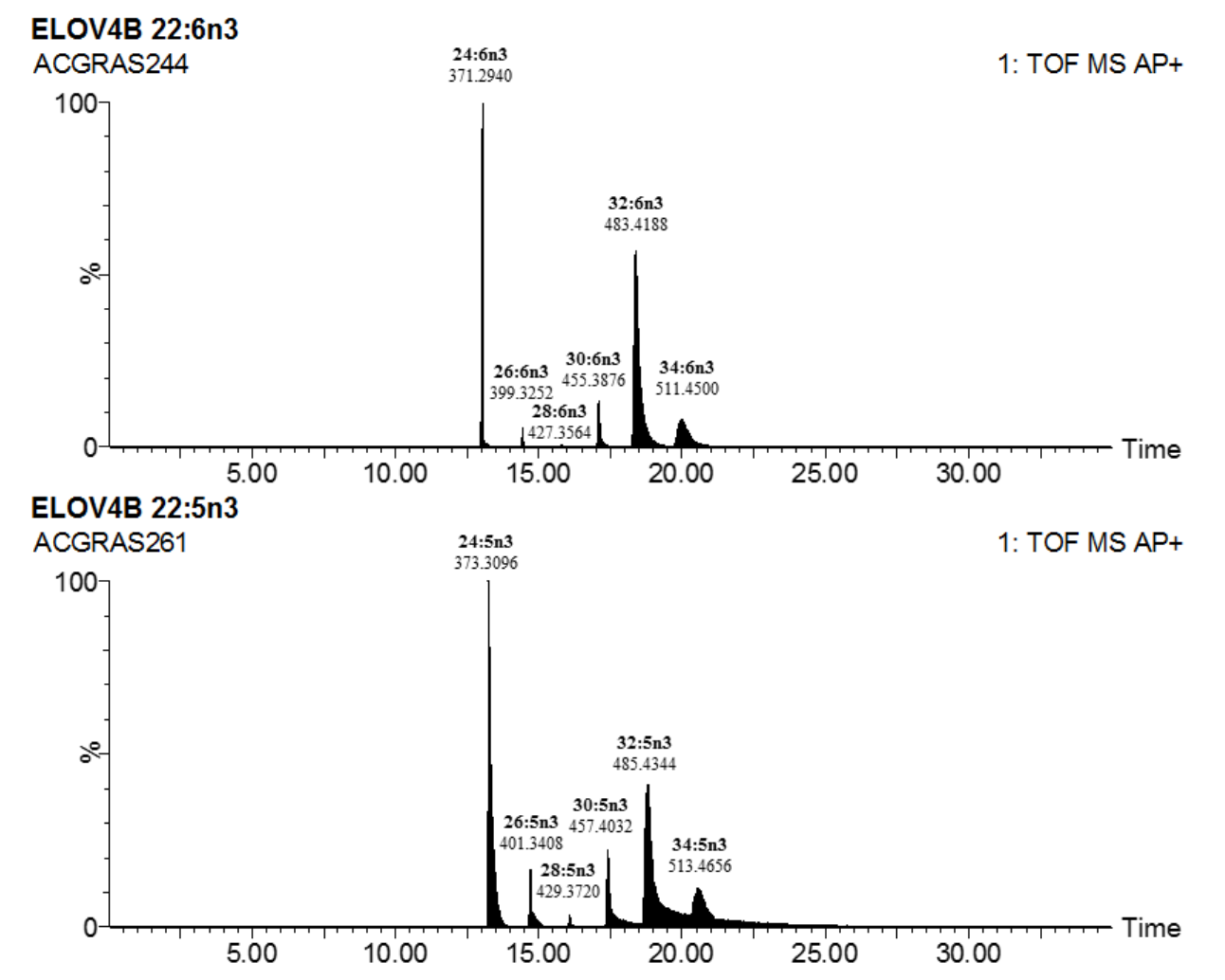

Figure 5: Extracted ion chromatograms for the elongation products coming

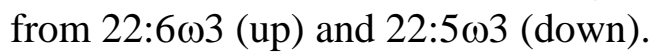




\section{CONCLUSIONS}

The use of an APCI interface in GC-QTOF has been employed for the first time to study the ionization and fragmentation behavior of FAMEs. The addition of water in the source as modifier promoted the proton transfer reaction producing mainly $[\mathrm{M}+\mathrm{H}]^{+}$species. In contrast to EI, low in-source fragmentation occurred in APCI. This fact together with the preservation of the protonated molecule measured at accurate mass has given an additional value to the reliable identification of VLC-PUFAs in real samples. The ratio between the ions with $\mathrm{m} / \mathrm{z} 121$ and $\mathrm{m} / \mathrm{z}, 163$ has been used for differentiation of $\omega 3$ and $\omega 6$ congeners. In addition, the heterologous expression experiments have enabled expanding our VLC-PUFA spectral library, and also establishing retention times for non-commercially available standards, thus improving characterization, identification and confirmation purposes. Results obtained in this paper will help to advance into the knowledge of the metabolism of these compounds.

\section{REFERENCES}

[1] P.C. Calder, N-3 Fatty Acids, Inflammation and Immunity: New Mechanisms To Explain Old Actions, Proc. Nutr. Soc. 72 (2013) 326-36. doi:10.1017/S0029665113001031.

[2] O. Monroig, J. Rotllant, J.M. Cerdá-Reverter, J.R. Dick, A. Figueras, D.R. Tocher, Expression and role of Elovl4 elongases in biosynthesis of very longchain fatty acids during zebrafish Danio rerio early embryonic development, Biochim. Biophys. Acta - Mol. Cell Biol. Lipids. 1801 (2010) 1145-1154. 
doi:10.1016/j.bbalip.2010.06.005.

[3] C.I.F. Janssen, A.J. Kiliaan, Long-chain polyunsaturated fatty acids (LCPUFA) from genesis to senescence: The influence of LCPUFA on neural development, aging, and neurodegeneration, Prog. Lipid Res. 53 (2014) 1-17. doi:10.1016/j.plipres.2013.10.002.

[4] E.J. Johnson, E.J. Schaefer, Potential role of dietary n-3 fatty acids in the prevention of dementia and macular degeneration, Am. J. Clin. Nutr. 83 (2006) 1494S-1498S.

[5] G. Schmitz, J. Ecker, The opposing effects of n-3 and n-6 fatty acids, Prog. Lipid Res. 47 (2008) 147-155. doi:10.1016/j.plipres.2007.12.004.

[6] M.I. Aveldano, A novel group of very long chain polyenoic fatty acids in dipolyunsaturated phosphatidylcholines from vertebrate retina, J. Biol. Chem. 262 (1987) 1172-1179.

[7] A. Poulos, Very long chain fatty acids in higher animals - A review, Lipids. 30 (1995) 1-14. doi:10.1007/BF02537036.

[8] M.-P. Agbaga, M.N. a Mandal, R.E. Anderson, Retinal very long-chain PUFAs: new insights from studies on ELOVL4 protein, J. Lipid Res. 51 (2010) 1624-42. doi:10.1194/jlr.R005025.

[9] P. Barabas, A. Liu, W. Xing, C.-K. Chen, Z. Tong, C.B. Watt, B.W. Jones, P.S. Bernstein, D. Križaj, Role of ELOVL4 and very long-chain polyunsaturated fatty acids in mouse models of Stargardt type 3 retinal degeneration., Proc. Natl. Acad. Sci. U. S. A. 110 (2013) 5181-6. doi:10.1073/ pnas. 1214707110 . 
[10] R. Harkewicz, H. Du, Z. Tong, H. Alkuraya, M. Bedell, W. Sun, X. Wang, Y.H. Hsu, J. Esteve-Rudd, G. Hughes, Z. Su, M. Zhang, V.S. Lopes, R.S. Molday, D.S. Williams, E. a. Dennis, K. Zhang, Essential role of ELOVL4 protein in very long chain fatty acid synthesis and retinal function, J. Biol. Chem. 287 (2012) 11469-11480. doi:10.1074/jbc.M111.256073.

[11] A. Liu, R. Terry, Y. Lin, K. Nelson, P.S. Bernstein, Comprehensive and sensitive quantification of long-chain and very long-chain polyunsaturated fatty acids in small samples of human and mouse retina., J. Chromatogr. A. 1307 (2013) 191-200. doi:10.1016/j.chroma.2013.07.103.

[12] O. Berdeaux, P. Juaneda, L. Martine, S. Cabaret, L. Bretillon, N. Acar, Identification and quantification of phosphatidylcholines containing verylong-chain polyunsaturated fatty acid in bovine and human retina using liquid chromatography/tandem mass spectrometry, J. Chromatogr. A. 1217 (2010) 7738-48. doi:10.1016/j.chroma.2010.10.039.

[13] R. Taguchi, M. Ishikawa, Precise and global identification of phospholipid molecular species by an Orbitrap mass spectrometer and automated search engine Lipid Search, J. Chromatogr. A. 1217 (2010) 42294239. doi:10.1016/j.chroma.2010.04.034.

[14] X. Li, A.A. Franke, Improved LC-MS Method for the Determination of Fatty Acids in Red Blood Cells by LC-Orbitrap MS, (2011) 3192-3198.

[15] L. Tedone, R. Costa, S. De Grazia, S. Ragusa, L. Mondello, Monodimensional (GC-FID and GC-MS) and comprehensive twodimensional gas chromatography for the assessment of volatiles and fatty acids from Ruta chalepensis aerial parts, Phytochem. Anal. 25 (2014) 468- 
475. doi:10.1002/pca.2518.

[16] M. Volpato, J.A. Spencer, A.D. Race, A. Munarini, A. Belluzzi, A.J. Cockbain, M.A. Hull, P.M. Loadman, A liquid chromatography-tandem mass spectrometry method to measure fatty acids in biological samples, J. Chromatogr. B. 1055-1056 (2017) 125-134. doi:10.1016/j.jchromb.2017.04. 030.

[17] J. Pettersen, Determination of trans double bonds in polyunsaturated fatty acid methyl esters from their electron impact mass spectra. Eur. J. Lipid Sci. Technol. 105 (2003) 156-164.

[18] D.-P. Kloos, E. Gay, H. Lingeman, F. Bracher, C. Müller, O. a Mayboroda, A.M. Deelder, W.M. a Niessen, M. Giera, Comprehensive gas chromatography-electron ionisation mass spectrometric analysis of fatty acids and sterols using sequential one-pot silylation: quantification and isotopologue analysis., Rapid Commun. Mass Spectrom. 28 (2014) 1507-14. doi:10.1002/rcm.6923.

[19] T. Portolés, L. Cherta, J. Beltran, F. Hernández, Improved gas chromatography-tandem mass spectrometry determination of pesticide residues making use of atmospheric pressure chemical ionization, J. Chromatogr. A. 1260 (2012) 183-192. doi:10.1016/j.chroma.2012.08.009.

[20] M. Raro, T. Portolés, J. V Sancho, E. Pitarch, F. Hernández, J. Marcos, R. Ventura, C. Gómez, J. Segura, O.J. Pozo, Mass spectrometric behavior of anabolic androgenic steroids using gas chromatography coupled to atmospheric pressure chemical ionization source. Part I: ionization, J. Mass Spectrom. 49 (2014) 509-21. doi:10.1002/jms.3367. 
[21] E. Hurtado-Fernández, T. Pacchiarotta, E. Longueira-Suárez, O. a Mayboroda, A. Fernández-Gutiérrez, A. Carrasco-Pancorbo, Evaluation of gas chromatography-atmospheric pressure chemical ionization-mass spectrometry as an alternative to gas chromatography-electron ionizationmass spectrometry: avocado fruit as example., J. Chromatogr. A. 1313 (2013) 228-44. doi:10.1016/j.chroma.2013.08.084.

[22] R. García-Villalba, T. Pacchiarotta, A. Carrasco-Pancorbo, A. SeguraCarretero, A. Fernández-Gutiérrez, A.M. Deelder, O.A. Mayboroda, Gas chromatography-atmospheric pressure chemical ionization-time of flight mass spectrometry for profiling of phenolic compounds in extra virgin olive oil, J. Chromatogr. A. 1218 (2011) 959-971. doi:10.1016/j.chroma.2010. 12.014 .

[23] K. Hennig, J.P. Antignac, E. Bichon, M.-L. Morvan, I. Miran, S. Delaloge, J. Feunteun, B. Le Bizec, Steroid hormone profiling in human breast adipose tissue using semi-automated purification and highly sensitive determination of estrogens by GC-APCI-MS/MS, Anal. Bioanal. Chem. 410 (2018) 259-275. doi:10.1007/s00216-017-0717-8.

[24] E. Bichon, I. Guiffard, A. Vénisseau, E. Lesquin, V. Vaccher, A. Brosseaud, P. Marchand, B. Le Bizec, Simultaneous determination of 16 brominated flame retardants in food and feed of animal origin by fast gas chromatography coupled to tandem mass spectrometry using atmospheric pressure chemical ionisation, J. Chromatogr. A. 1459 (2016) 120-128. doi:10.1016/j.chroma.2016.07.003.

[25] F. Hernández, M. Ibáñez, T. Portolés, M.I. Cervera, J. V Sancho, F.J. López, Advancing towards universal screening for organic pollutants in 
waters., J. Hazard. Mater. 282 (2015) 86-95. doi:10.1016/j.jhazmat.2014.08. 006.

[26] L. Cherta, T. Portolés, J. Beltran, E. Pitarch, J.G.J. Mol, F. Hernández, Application of gas chromatography-(triple quadrupole) mass spectrometry with atmospheric pressure chemical ionization for the determination of multiclass pesticides in fruits and vegetables, J. Chromatogr. A. 1314 (2013) 224-240. doi:10.1016/j.chroma.2013.09.029.

[27] M.I. Aveldano, H. Sprecher, Very long chain (C24 to C36) polyenoic fatty acids of the n-3 and n-6 series in dipolyunsaturated phosphatidylcholines from bovine retina, J. Biol. Chem. 262 (1987) 1180-1186.

[28] A. Liu, Y. Lin, R. Terry, K. Nelson, P.S. Bernstein, Role of long-chain and very-long-chain polyunsaturated fatty acids in macular degenerations and dystrophies, Clin. Lipidol. 6 (2011) 593-613. doi:10.2217/clp.11.41.

[29] A. Liu, J. Chang, Y. Lin, Z. Shen, P.S. Bernstein, Long-chain and very long-chain polyunsaturated fatty acids in ocular aging and age-related macular degeneration., J. Lipid Res. 51 (2010) 3217-29. doi:10.1194/jlr.M007518.

[30] D.R. Tocher, Omega-3 long-chain polyunsaturated fatty acids and aquaculture in perspective, Aquaculture. 449 (2015) 94-107. doi:10.1016/ j.aquaculture.2015.01.010.

[31] S. Li, Ó. Monroig, T. Wang, Y. Yuan, J. Carlos Navarro, F. Hontoria, K. Liao, D.R. Tocher, K. Mai, W. Xu, Q. Ai, Functional characterization and differential nutritional regulation of putative Elovl5 and Elovl4 elongases in large yellow croaker (Larimichthys crocea), Sci. Rep. 7 (2017). doi:10.1038/ s41598-017-02646-8. 
[32] G. Carmona-Antoñanzas, Ó. Monroig, J.R. Dick, A. Davie, D.R. Tocher, Biosynthesis of very long-chain fatty acids $(\mathrm{C}>24)$ in Atlantic salmon: Cloning, functional characterisation, and tissue distribution of an Elovl4 elongase, Comp. Biochem. Physiol. - B Biochem. Mol. Biol. 159 (2011) 122129. doi:10.1016/j.cbpb.2011.02.007.

[33] A. Jakobsson, R. Westerberg, A. Jacobsson, Fatty acid elongases in mammals: Their regulation and roles in metabolism, Prog. Lipid Res. 45 (2006) 237-249. doi:10.1016/j.plipres.2006.01.004.

[34] Folch J.; Lees M.; Stanley G. H. S., J. Folch, M. Lees, G.H.S. Stanley, A simple method for the isolation and purification of total lipids from animal tissues, J Biol Chem. 226 (1957) 497-509. doi:10.1007/s10858-011-9570-9.

[35] R.E. Olsen, R.J. Henderson, The rapid analysis of neutral and polar marine lipids using double-development HPTLC and scanning densitometry, J. Exp. Mar. Bio. Ecol. 129 (1989) 189-197. doi:10.1016/0022-0981(89) 90056-7.

[36] J.C. Navarro, F. Amat, J.R. Sargent, A study of the variations in lipid levels, lipid class composition and fatty acid composition in the first stages of Artemia sp., Mar. Biol. 111 (1991) 461-465. doi:10.1007/BF01319419.

[37] W.W. Christie, Lipid analysis, Pergamon Press Oxford; 2nd edition, 1982.

[38] T. Portolés, C. Sales, B. Gómara, J.V. Sancho, J. Beltrán, L. Herrero, M.J. González, F. Hernández, Novel analytical approach for brominated flame retardants based on the use of gas chromatography-atmospheric pressure chemical ionization-tandem mass spectrometry with emphasis in highly 
brominated congeners., Anal. Chem. 87 (2015) 9892-9. doi:10.1021/acs. analchem.5b02378. 



\subsection{Discusión de los resultados obtenidos}

Como se ha comentado en la introducción de este capítulo, el principal inconveniente del análisis de VLC-PUFA reside en la ausencia de patrones de referencia comercialmente disponibles, pues implica la ausencia de bases de datos espectrales fiables $y$, por tanto, supone una dificultad añadida a la hora de confirmar la identidad de estos compuestos. Por este motivo, la identificación de los compuestos recae principalmente en la información estructural obtenida mediante el análisis espectrométrico. Tradicionalmente, el análisis de VLC-PUFA-MEs se ha llevado a cabo mediante el acoplamiento GC-MS con fuente EI, obteniendo información estructural poco específica dada la pérdida total y/o parcial del $\mathrm{M}^{+\cdot}$. Ante esta problemática, el artículo científico IV aporta una estrategia novedosa para la identificación de VLCPUFA-MEs sin necesidad de patrones analíticos mediante la técnica GCAPCI-QTOF MS.

En primer lugar, dada la novedad del uso de la fuente APCI en esta aplicación, ha sido necesaria la creación de una base de datos experimental y teórica que contenga información espectral y/o cromatográfica. La base de datos teórica se basa en listados de VLC-PUFA reportados en la literatura para los cuales no hay patrones analíticos disponibles. Esta base de datos teórica incluye la fórmula molecular de cada compuesto y la masa exacta de $\mathrm{M}^{+\cdot}$ y $[\mathrm{M}+\mathrm{H}]^{+}$. Para crear la base de datos experimental, se llevó a cabo el estudio de la ionización y fragmentación de quince ésteres metílicos de ácidos grasos (FAMEs) saturados e insaturados $\omega 3$ y $\omega 6$ - disponibles comercialmente poniendo especial énfasis en sus diferencias estructurales. La adquisición en modo $\mathrm{MS}^{\mathrm{E}}$ permitió obtener en una misma inyección los espectros completos de LE y HE con elevada exactitud de masa. 
Pese a mantener prácticamente intacta la $[\mathrm{M}+\mathrm{H}]^{+}$en la función LE, los LCPUFA-MEs estudiados mostraron fragmentos comunes, independientemente del carácter $\omega 6$ o $\omega 3$, en la función HE (ver figura 1). Sin embargo, sí que presentaban diferencias en las abundancias relativas de algunos fragmentos estructurales.

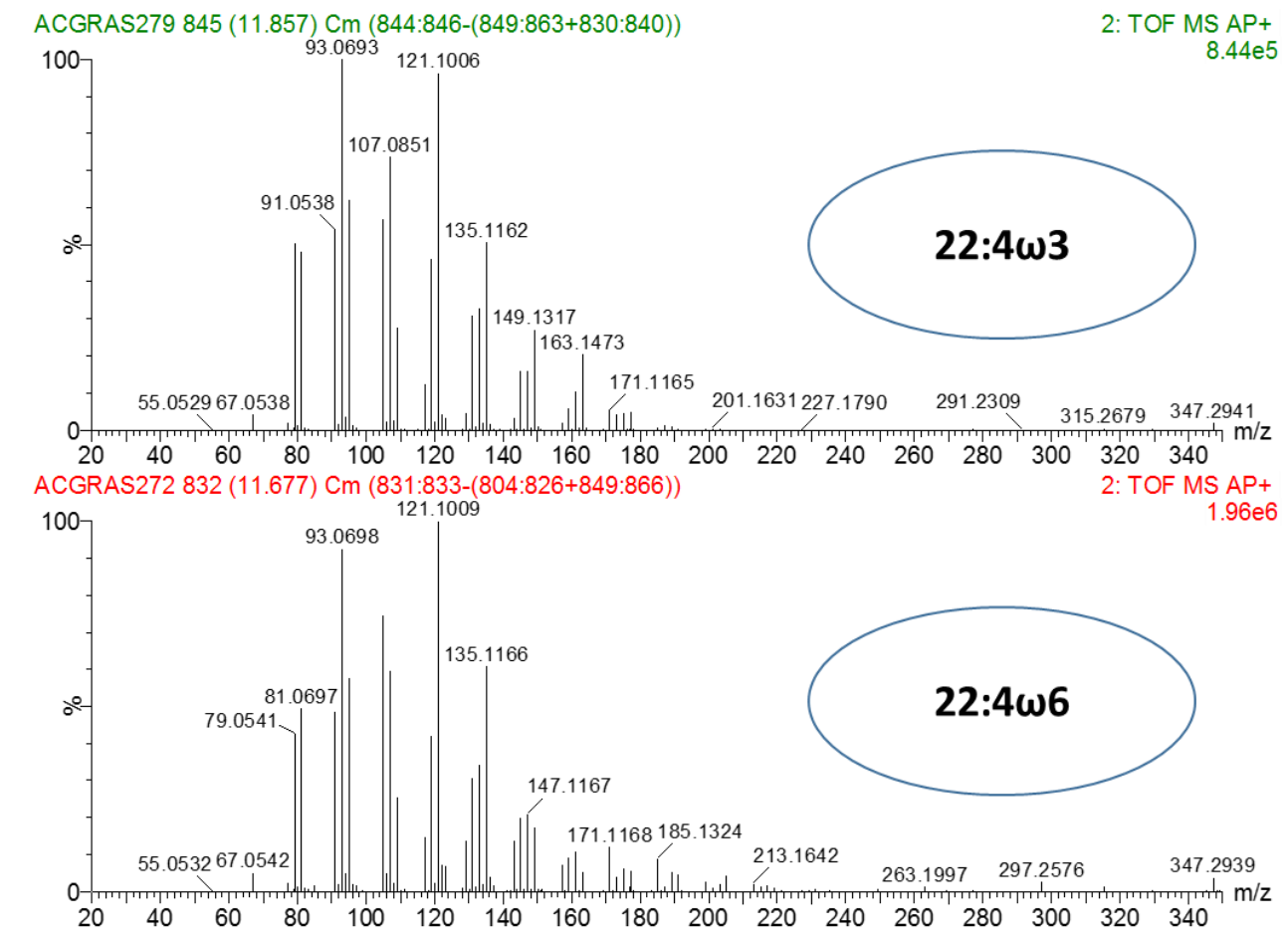

Figura 1: Espectros de APCI en la función de HE de los ésteres metílicos

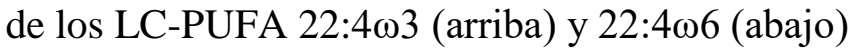

Con el objetivo de diferenciar los ácidos grasos isoméricos $\omega 6$ de los $\omega 3$ mediante un modelo estadístico, se creó una matriz de datos con la abundancia de cada fragmento relativa a la del ion $\mathrm{m} / \mathrm{z}$ 121, que es el pico base del espectro

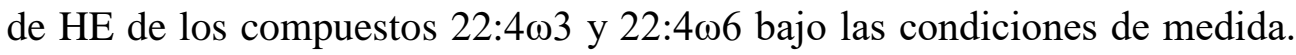
Para contemplar también la consistencia de las abundancias relativas, la matriz 
contenía los datos de cinco inyecciones consecutivas de los estándares. Considerando un análisis estadístico completamente imparcial, en primer lugar se aplicó un análisis de componentes principales (PCA) sobre la matriz de datos, mostrando una distinción aproximada entre $\omega 3$ y $\omega 6$. A continuación, se realizó un análisis ortogonal de mínimos cuadrados parciales discriminantes (OPLS-DA), generando un modelo que destacó la abundancia relativa entre los iones $\mathrm{m} / \mathrm{z}, 121$ y 163 como la variable diferenciadora de ambos grupos.

A fin de validar el modelo y evaluar su alcance en la clasificación de VLCPUFA se llevó a cabo el análisis de diferentes experimentos de expresión heteróloga, es decir, se analizaron los productos de elongación in vitro de diferentes LC-PUFA $\omega 3$ y $\omega 6$ generados por la elongasa ELOVL4 en levadura. Como resultado, se observó que el modelo clasificaba correctamente los productos de elongación.

Por último, su aplicación en el análisis de muestras reales junto con los criterios de identificación de métodos de screening descritos a lo largo de esta tesis, permitió identificar sin error diferentes VLC-PUFA en retinas de salmón, dorada, lenguado y lubina sin necesidad de patrones analíticos. La identidad de los compuestos se confirmó, en última instancia, a partir de los experimentos de expresión heteróloga, reafirmando así la fiabilidad del método.

Pese a demostrar la fiabilidad de la estrategia propuesta, cabe remarcar que el modelo estadístico presentado se basa en datos espectrométricos generados bajo unas condiciones instrumentales concretas. La fragmentación de los compuestos y, por tanto, la abundancia relativa entre los fragmentos, depende 
de parámetros como el voltaje de cono, la rampa de energía de colisión y las condiciones de ionización. Por este motivo, los estudios futuros deberán evaluar la robustez del modelo al cambiar las condiciones instrumentales, bien para el mismo equipo o transferido a otros. 


\subsection{Referencias}

1. Calder PC (2013) N-3 Fatty Acids, Inflammation and Immunity: New Mechanisms To Explain Old Actions. Proc Nutr Soc 72:326-36. doi: $10.1017 /$ S0029665113001031

2. Ibeas C, Izquierdo MS, Lorenzo A (1994) Effect of different levels of n-3 highly unsaturated fatty acids on growth and fatty acid composition of juvenile gilthead seabream (Sparus aurata). Aquaculture. doi: 10.1016/ 0044-8486(94)90424-3

3. Agbaga M-P, Brush RS, Mandal MNA, Henry K, Elliott MH, Anderson RE (2008) Role of Stargardt-3 macular dystrophy protein (ELOVL4) in the biosynthesis of very long chain fatty acids. Proc Natl Acad Sci USA 105:12843-12848. doi: 10.1073/pnas.0802607105

4. Aveldaño MI, Sprecher H (1987) Very long chain (C24 to C36) polyenoic fatty acids of the $n-3$ and $n-6$ series in dipolyunsaturated phosphatidylcholines from bovine retina. J Biol Chem 262:1180-6

5. Suh M, Wierzbicki AA, Clandinin MT (2002) Dietary n-3 FA modulate long and very long chain FA content, rhodopsin content, and rhodopsin phosphorylation in rat rod outer segment after light exposure. Lipids. doi: 10.1007/s11745-002-0888-0

6. McMahon A, Jackson SN, Woods AS, Kedzierski W (2007) A Stargardt disease- 3 mutation in the mouse ELOVL4 gene causes retinal deficiency of C32-C36 acyl phosphatidylcholines. FEBS Lett. doi: 10.1016/j.febslet. 2007.10.050 
7. Poulos A (1995) Very long chain fatty acids in higher animals-A review. Lipids 30:1-14. doi: 10.1007/BF02537036

8. Robinson BS, Johnson DW, Poulos A (1990) Unique molecular species of phosphatidylcholine containing very-long-chain (C24-C38) polyenoic fatty acids in rat brain. Biochem J. doi: 10.1042/bj2650763

9. Aveldaño MI, Robinson BS, Johnson DW, Poulos A (1993) Long and very long chain polyunsaturated fatty acids of the $n-6$ series in rat seminiferous tubules. J Biol Chem

10. Furland NE, Maldonado EN, Aveldaño MI (2003) Very Long Chain Polyunsaturated Fatty Acids in Murine Testicular Tri-glycerides and Cholesterol Esters. 1666:

11. McMahon A, Kedzierski W (2010) Polyunsaturated very-long-chain C28-C36 fatty acids and retinal physiology. Br. J. Ophthalmol.

12. Monroig O, Rotllant J, Cerdá-Reverter JM, Dick JR, Figueras A, Tocher DR (2010) Expression and role of Elovl4 elongases in biosynthesis of very long-chain fatty acids during zebrafish Danio rerio early embryonic development. Biochim Biophys Acta - Mol Cell Biol Lipids. doi: 10.1016/j.bbalip.2010.06.005

13. Monroig Ó, Webb K, Ibarra-Castro L, Holt GJ, Tocher DR (2011) Biosynthesis of long-chain polyunsaturated fatty acids in marine fish: Characterization of an Elovl4-like elongase from cobia Rachycentron canadum and activation of the pathway during early life stages. Aquaculture 312:145-153. doi: 10.1016/j.aquaculture.2010.12.024 
14. Carmona-Antoñanzas G, Monroig Ó, Dick JR, Davie A, Tocher DR (2011) Biosynthesis of very long-chain fatty acids (C > 24) in Atlantic salmon: Cloning, functional characterisation, and tissue distribution of an Elovl4 elongase. Comp Biochem Physiol Part B Biochem Mol Biol 159:122-129. doi: 10.1016/J.CBPB.2011.02.007

15. Monroig Ó, Wang S, Zhang L, You C, Tocher DR, Li Y (2012) Elongation of long-chain fatty acids in rabbitfish Siganus canaliculatus: Cloning, functional characterisation and tissue distribution of Elov15- and Elovl4-like elongases. Aquaculture. doi: 10.1016/j.aquaculture.2012.04.017

16. Volpato M, Spencer JA, Race AD, Munarini A, Belluzzi A, Cockbain AJ, Hull MA, Loadman PM (2017) A liquid chromatography-tandem mass spectrometry method to measure fatty acids in biological samples. J Chromatogr B 1055-1056:125-134. doi: 10.1016/j.jchromb .2017 .04 .030

17. Pettersen J (2003) Determination of trans double bonds in polyunsaturated fatty acid methyl esters from their electron impact mass spectra. Eur. J. Lipid Sci. Technol. 105:156-164.

18. Kloos D-P, Gay E, Lingeman H, Bracher F, Müller C, Mayboroda OA, Deelder AM, Niessen WMA, Giera M (2014) Comprehensive gas chromatography-electron ionisation mass spectrometric analysis of fatty acids and sterols using sequential one-pot silylation: quantification and isotopologue analysis. Rapid Commun Mass Spectrom 28:1507-14. doi: 10.1002/rcm.6923 

CAPítulo 5

\section{CONCLUSIONES/CONCLUSIONS}





\section{CONCLUSIONES}

La conclusion general derivada de los trabajos realizados en la presente Tesis Doctoral es que el potencial de las técnicas instrumentales disponibles actualmente, junto con la fiabilidad de los métodos analíticos desarrollados, hacen de la química analítica una disciplina fundamental en las ciencias ambientales, demostrando ser una herramienta muy útil para abordar y resolver problemas de seguridad alimentaria y medioambientales, entre otros.

De los trabajos presentados en esta Tesis Doctoral se pueden extraer las siguientes conclusiones específicas:

1) El screening mediante LC-QTOF MS y GC-APCI-QTOF MS permite abordar, de forma rápida, sensible y fiable, el análisis de un gran rango de compuestos con diferentes propiedades físico-químicas. El uso conjunto de ambas técnicas es completamente necesario para abordar analíticamente nuevas problemáticas ambientales.

2) El potencial del acoplamiento GC-APCI-MS/MS con analizador QqQ permite reducir el efecto matriz en muestras complejas mediante dilución simple del extracto, posibilitando la cuantificación de las mismas mediante calibrado en solvente relativo a SIL-IS.

3) La estrategia integral para el análisis de pesticidas, PAHs y PCBs en muestras de acuicultura se presenta como una herramienta fiable para la evaluación de riesgos durante el ciclo de producción acuícola.

4) El acoplamiento LC-MS/MS es una técnica poderosa, rápida y fiable para la determinación de pesticidas y sus metabolitos en matrices complejas debido a su elevada sensibilidad y selectividad. 
5) El análisis de muestras de pez cebra y salmón sometidas a la exposición dietaria de pirimiphos-methyl permitirá crear un modelo cinético de acumulación y eliminación que contribuirá a establecer MRLs seguros y objetivos en pescado.

6) El uso de la fuente de ionización APCI supone un avance en la investigación de VLC-PUFA, incrementando la fiabilidad en el proceso de identificación de los compuestos.

7) Los experimentos de expresión heteróloga permiten generar compuestos de referencia para la validación de modelos estadísticos de identificación de VLC-PUFA. 


\section{CONCLUSIONS}

The general conclusion of this Doctoral Thesis is that the potential of the currently available instrumental techniques, together with the reliability of the analytical methods developed, make analytical chemistry an essential discipline in environmental sciences, proving to be a very useful tool to address and solve food safety and environmental problems, among others.

As a result of the research performed in this work, several specific conclusions can be extracted:

1) The screening by LC-QTOF MS and GC-APCI-QTOF MS allows the fast, sensitive and reliable analysis of a wide range of compounds with different physicochemical properties. The complementary use of both techniques is required to face new environmental problems.

2) The potential of GC-APCI-MS/MS with QqQ analyzer allows reducing the matrix effect in complex samples by simple dilution of the extract, making it possible to quantify them by calibration with standards in solvent relative to SIL-IS.

3) The comprehensive strategy for the analysis of pesticides, PAHs and PCBs in aquaculture samples is a reliable tool for risk assessment during the aquaculture production cycle.

4) The LC-MS/MS coupling is a powerful, fast and reliable technique for the determination of pesticides and their metabolites in complex matrices due to its high sensitivity and selectivity.

5) The analysis of zebrafish and salmon samples subjected to the dietary 
exposure of pirimiphos-methyl will allow the creation of a kinetic model of accumulation and elimination that will contribute to establish reliable and objective MRLs in fish.

6) The use of the APCI ionization source represents an advance in the research of VLC-PUFA, increasing the reliability in the process of identification of the compounds.

7) The heterologous expression experiments allow generating reference compounds for the validation of statistical models for the identification of VLC-PUFA. 


\section{SUGERENCIAS PARA FUTUROS TRABAJOS}

El trabajo realizado en la presente Tesis Doctoral se ha desarrollado en base a la instrumentación disponible en el Institut Universitari de Plaguicides i Aigües durante un periodo de tres años. Sin embargo, la metodología presentada podría enriquecerse, reevaluarse o mejorarse gracias, en parte, a la aparición y adquisición de nuevos sistemas instrumentales.

Por un lado, la aparición de espectrómetros de masas con movilidad iónica, como el VION IMS QTOF, supone un avance en el screening de contaminantes orgánicos. Debido a la naturaleza ortogonal de la separación por movilidad iónica, este sistema instrumental es capaz de resolver, en muchos casos, compuestos coeluyentes y permite la detección de componentes que pueden haber estado ocultos por la matriz o mostrar especies isoméricas que no pueden separarse por cromatografía. Además, la separación por movilidad iónica introduce una nueva variable identificativa: la sección transversal de colisión (CCS), lo que podría traducirse en una mejora en la capacidad de identificación. Por esta razón, sería interesante explorar en futuros trabajos el potencial de los acoplamientos LC-IMS QTOF MS y GCAPCI-IMS QTOF MS para el screening de contaminantes orgánicos en muestras de acuicultura y, así, comparar la detectabilidad y la capacidad de identificación con la reportada en el artículo científico I. Además, este sistema instrumental puede ser de gran utilidad para estudios de metabolismo. Tal es así que Bijlsma et al (2019) [1] han explorado recientemente el potencial de esta técnica para investigar la presencia de otros metabolitos del pirimiphos-methyl no reportados en los extractos de músculo, hígado, riñón, bilis y grasa de salmón utilizados en el artículo científico III. 
Por otro lado, algunos de los métodos presentados requieren de una ampliación del estudio, como puede ser el caso del artículo científico IV que, pese a haber demostrado la fiabilidad de la estrategia propuesta para la identificación de VLC-PUFA, sería recomendable evaluar la robustez de la misma al cambiar las condiciones instrumentales. Además, puede ser de gran interés buscar aproximaciones para la cuantificación de estos compuestos ya que, a la dificultad analítica en la identificación, se suma la dificultad en la cuantificación.

1. Bijlsma L, Berntssen MHG, Merel S (2019) A Refined Nontarget Workflow for the Investigation of Metabolites through the Prioritization by in Silico Prediction Tools. Anal Chem. doi: 10.1021/acs.analchem.9b01218 


\section{SUGGESTIONS FOR FUTURE WORKS}

The work performed in this Doctoral Thesis has been developed according to the instruments available at the Research Institute for Pesticides and Water for a period of three years. However, the methodology presented could be enriched, reevaluated or improved thanks, in part, to the availability of new instrumental systems.

On the one hand, the emergence of ion mobility separation mass spectrometers, such as the VION IMS QTOF, represents an advance in the screening of organic pollutants. Due to the orthogonal nature of ion mobility separation, this instrumental system can resolve, in many cases, coeluting compounds and allows the detection of components that may have been hidden by the matrix or show isomeric species that cannot be separated by chromatography. In addition, ion mobility separation introduces a new identification factor: the collisional cross section (CCS), which could improve the identification capacity. For this reason, it would be interesting to explore in future works the potential of LC-IMS QTOF MS and GC-APCI-IMS QTOF MS for the screening of organic pollutants in aquaculture samples and, thus, compare the detectability and identification capacity with the one reported in the scientific article I. In addition, this instrumental system can be very useful for metabolism studies. In fact, Bijlsma et al (2019) [1] recently explored the potential of this technique to investigate the presence of other unreported pyrimiphos-methyl metabolites in muscle, liver, kidney, bile and salmon fat extracts used in the scientific article III.

On the other hand, some of the methods require an extension of the study, such as that presented in the scientific article IV in which, despite having 
demonstrated the reliability of the proposed strategy for the identification of VLC-PUFA, the evaluation of the robustness when changing the instrumental conditions would be recommended. In addition, it may be of great interest to look for quantitative approches for the determination of these compounds since, to the analytical difficulty in the identification, the difficulty in the quantification is added.

1. Bijlsma L, Berntssen MHG, Merel S (2019) A Refined Nontarget Workflow for the Investigation of Metabolites through the Prioritization by in Silico Prediction Tools. Anal Chem. doi: 10.1021/acs.analchem.9b01218 


\section{ARTÍCULOS RELACIONADOS/RELATED ARTICLES}

Sanden M, Olsvik PA, Søfteland L, Rasinger JD, Rosenlund G, Garlito B, Ibáñez M, Berntssen MHG (2018) Dietary pesticide chlorpyrifos-methyl affects arachidonic acid metabolism including phospholipid remodeling in Atlantic salmon (Salmo salar L.). Aquaculture 484:1-12. doi: 10.1016/j.aquaculture.2017.10.033

Nácher-Mestre J, Ballester-Lozano GF, Garlito B, Portolés T, Calduch-Giner J, Serrano R, Hernández F, Berntssen MHG, Pérez-Sánchez J (2018) Comprehensive overview of feed-to-fillet transfer of new and traditional contaminants in Atlantic salmon and gilthead sea bream fed plant-based diets. Aquac Nutr 24:1782-1795. doi: 10.1111/anu.12817 